UNIVERSIDADE DE SÃO PAULO

FACULDADE DE FILOSOFIA, LETRAS E CIÊNCIAS HUMANAS

DEPARTAMENTO DE SOCIOLOGIA

PROGRAMA DE PÓS-GRADUAÇÃO EM SOCIOLOGIA

LUIZA MARIA DE ASSUNÇÃO

\title{
Campo psiquiátrico e campo religioso: entre diálogos e tensões
}

SÃO PAULO

2010 
UNIVERSIDADE DE SÃO PAULO

FACULDADE DE FILOSOFIA, LETRAS E CIÊNCIAS HUMANAS

DEPARTAMENTO DE SOCIOLOGIA

PROGRAMA DE PÓS-GRADUAÇÃO EM SOCIOLOGIA

\title{
Campo psiquiátrico e campo religioso: entre diálogos e tensões
}

\author{
LUIZA MARIA DE ASSUNÇÃO
}

\begin{abstract}
Tese apresentada ao Programa de Pósgraduação em Sociologia do Departamento de Sociologia da Faculdade de Filosofia, Letras e Ciências Humanas da Universidade de São Paulo, para obtenção do título de Doutor em sociologia.
\end{abstract}

Orientador: Prof. Dr. Lísias Nogueira Negrão

São Paulo

2010 
FOLHA DE APROVAÇÃO

Luiza Maria de Assunção

Campo psiquiátrico e campo religioso: entre diálogos e tensões

Tese apresentada ao Programa de PósGraduação em Sociologia do Departamento de Sociologia da Faculdade de Filosofia, Letras e Ciências Humanas da Universidade de São Paulo, para obtenção do título de Doutor em sociologia.

Aprovado em:

Banca Examinadora

Prof. Dr.

Instituição:

Assinatura

Prof. Dr.

Instituição:

Assinatura

Prof. Dr.

Instituição:

Assinatura

Prof. Dr.

Instituição:

Assinatura

Prof. Dr.

Instituição:

Assinatura 
À minha mãe, Maria Luiza e a Ricardo, meu amor 


\section{AGRADECIMENTOS}

Agradeço, primeiramente, a meu orientador, Lísias Nogueira Negrão, pela confiança e apoio ao longo destes anos de mestrado e doutorado, pelas sugestões relativas à tese e pelas conversas amigas.

Às professoras Maria Helena Oliva Augusto, Maria Helena Villas Boas Concone pelas críticas e sugestões no exame de qualificação. Ao professor François Bonvin, que muito contribuiu esclarecendo dúvidas e sugerindo leituras. À Selma Paiva pela ajuda na transcrição das entrevistas, à Evelise pela revisão cuidadosa da tese e à Adriana Capuchinho pela redação do abstract. Ao Andreas pela tradução de texto do alemão para o português.

A Francisco Lotufo-Neto: por abrir as portas do Instituto de Psiquiatria e pelo apoio nas questões de ordem burocrática. A Frederico Camelo Leão pelos convites e acolhimento nas reuniões do ProSER.

A todos os entrevistados (pacientes, psiquiatras, enfermeiros, padres, pastores e voluntários religiosos) que concederam um pouco do seu tempo para participar desta pesquisa, agradeço a confiança e a paciência.

Ao Ricardo, companheiro numa caminhada de doze anos, amigo nas horas difíceis, conselheiro diversas vezes. Agradeço a paciência, a dedicação e o apoio.

À Simone, que tem sido presença ímpar na minha vida: a confiança, o carinho e a escuta foram decisivos. Agradeço a coragem em compartilhar importantes momentos comigo.

À minha mãe Maria Luiza, ao meu pai José Paula (In memoriam), aos irmãos Lázaro, Maria José, Edmur, Sandra e aos sobrinhos Rafael e Aline, pessoas com as quais compartilhei e ainda compartilho importantes e preciosos momentos da minha vida. Aos cunhados (Andreas e Ludovic) e às cunhadas (Ivana e Rozani) que, de alguma forma, acompanharam e estiveram presentes ao longo do percurso de doutorado.

À Verinha e ao Alcebíades, que sempre demonstraram preocupação e carinho nos pequenos gestos. 
À Marinê, amiga e companheira de estudos: pelas longas jornadas na biblioteca, pelas conversas, desabafos, cafezinhos.

Aos amigos Antônia, Irinéia, Marcinha, Nilton que, cada um a sua maneira, estiveram presentes ao longo desses anos de universidade.

Ao CNPQ, cujo financiamento possibilitou a realização desta tese de doutorado. 
Há três cousas com que um espírito nobre, de velho ou de jovem, nunca brinca, porque o brincar com elas é um dos sinais distintivos da baixeza da alma: são elas os deuses, a morte e a loucura [...] É a loucura que dirige o mundo. Loucos são os heróis, loucos são os santos, loucos são os gênios, sem os quais a humanidade é uma mera espécie animal, cadáveres adiados que procriam.

(Fernando Pessoa) 


\section{RESUMO}

ASSUNÇÃO, L. M. Campo psiquiátrico e campo religioso: entre diálogos e tensões. 2010. 309 f. Tese (Doutorado) - Faculdade de Filosofia, Letras e Ciências Humanas, Universidade de São Paulo, São Paulo, 2010.

Nesta tese buscou-se analisar uma possível relação entre ciência e religião, mediante o diálogo entre psiquiatria e assistência religiosa hospitalar. Por intermédio dos porta-vozes desses dois domínios (psiquiatras e ministros religiosos), tentou-se captar em que moldes acontece o diálogo entre as duas especialidades, as quais, por meio de alguns de seus profissionais, têm buscado uma aproximação. A hipótese da qual se partiu é a de que, ao estabelecerem pontes de contato, os campos psiquiátrico e religioso tornam-se vulneráveis, podendo assim colocar em risco o seu desenvolvimento e a sua legalidade enquanto áreas de atuação autônomas. Para fazer a apreciação desse pressuposto, tomou-se como centro de análise os especialistas da saúde mental e os especialistas da religião que atuam junto ao Instituto de Psiquiatria (IPQ) do Hospital das Clínicas da Faculdade de Medicina da USP (HCFMUSP). O universo empírico, analisado em moldes qualitativos, é composto por 27 (vinte e sete) psiquiatras, 11 (onze) enfermeiros, 13 (treze) voluntários religiosos, 3 (três) ministros religiosos e 17 (dezessete) pacientes. A relação entre esses sujeitos foi pensada mediante a proposta bourdieusiana que trata do conflito entre campos sociais e do conflito interno a um determinado campo. Sob essa perspectiva foram conduzidas as reflexões e análises no presente trabalho. A partir da sistematização e do manuseio dos relatos dos informantes, constatou-se três formas de posicionamento no campo psiquiátrico e duas no campo religioso. No primeiro campo, elas se dividem em: mono-posicionado (psiquiatra "puro"), bi-posicionado (psiquiatra "espiritualista"), psiquiatra "neutro"/ambíguo. Já em relação ao campo religioso, as formas de posicionamento resumem-se a, de um lado, religiosos racionalizados e, de outro lado, religiosos "magicizados". Foi em função desses "lugares" ocupados nos dois campos que se realizaram as análises e que se verificaram os tipos de relações que são colocados em prática entre os dois campos e no interior de cada um deles. A postura preponderante foi de demarcação do território e ao mesmo tempo de sua flexibilização - postura essa principalmente levada a cabo pelos psiquiatras "neutros"/ambíguos e responsável por um processo de retradução no campo psiquiátrico que, da mesma forma que favorece o diálogo, impede a invasão e a respectiva perda de autonomia. Tomando como base essa constatação foi possível notar que, em oposição à hipótese levantada inicialmente, o campo psiquiátrico, no contato com o campo religioso, não perde sua autonomia. Ao contrário, realiza uma acomodação que reforça mais ainda o seu espaço de atuação.

Palavras-chave: Ciência, Medicina, Psiquiatria, religião, campo psiquiátrico, campo religioso. 


\begin{abstract}
ASSUNÇÃO, L. M. Psychiatric Field, Religious Field: between dialogues and tensions. 2010. 309 f. Thesis (PhD) - Faculdade de Filosofia, Letras e Ciências Humanas, Universidade de São Paulo, São Paulo, 2010. (Faculty of Philosophy, Languages and Social Sciences, University of São Paulo)

This thesis aimed to analyze the possibility of an association between science and religion, through the dialogue between psychiatry and religious hospital care. Through the spokespersons of these two domains (psychiatrists and religious ministers), we tried to observe the patterns of the dialogue between the two specialties which have pursued an approach through some of their practitioners. The starting hypothesis is that, by creating bridges of contact, the psychiatric and the religious fields become vulnerable and may jeopardize their development and their legality as autonomous areas of expertise. To observe that assumption, it was taken as the center of the analysis the mental health specialists and the experts in religion who work at the Institute of Psychiatry (IPQ) of Hospital das Clinicas of the Medical Faulty of USP (HCFMUSP). The universe, qualitatively regarded, comprises 27 (twenty seven) psychiatrists, 11 (eleven) nurses, 13 (thirteen) church volunteers, three (3) religious ministers and 17 (seventeen) patients. The relationship between the subjects was thought under the Bourdieusian proposal which deals with the conflict between social fields and with internal conflicts in a given field. The reflections and analysis were conducted in this study from this perspective. From the systematization and the handling of the informants' reports, we remarked three ways of positioning in the psychiatric field and two in the religious one. In the first field, they are divided in mono-positioned ("pure" psychiatrist), bi-positioned ("spiritual" psychiatrist), and "neutral"/ambiguous psychiatrists. In the religious field, the ways of positioning are reduced to, on the one hand, rationalist religious persons and, on the other hand, to "magicized" religious ones. The analysis was carried out regarding such "places", occupied in both fields, and it found the types of associations that are put into practice between the two fields and within each one of them. The prevailing attitude was the demarcation of territory and its flexibility at the same time. Such attitude is mainly carried out by "neutral"/ambiguous psychiatrists and it is responsible for a process of retranslation in psychiatry which, meanwhile it promotes dialogue, it prevents invasions and autonomy loss. Based on this observation it was remarkable that, opposed to the first hypothesis, the psychiatric field, in contact with the religious field, does not lose its autonomy. Instead, the psychiatric field accomplishes further accommodation which enhances its performance area.
\end{abstract}

Keywords: Science, Medicine, Psychiatry, religion, psychiatric field, religious field. 


\section{LISTA DE SIGLAS}

HCFMUSP- Hospital das Clínicas da Faculdade de Medicina da USP

IPQ- Instituto de Psiquiatria

NEPER- Núcleo de Estudos de Problemas Espirituais e Religiosos

ProSER- Programa de Saúde, Espiritualidade e Religiosidade

DSM4- Diagnostic and Statical Manual of Mental Disorders

CARE- Comitê de Assistência religiosa

M - Médico-Psiquiatra

E - Enfermeiro

AR - Autoridade religiosa

VR - Voluntário religioso

P - Paciente 


\section{LISTA DE QUADROS}

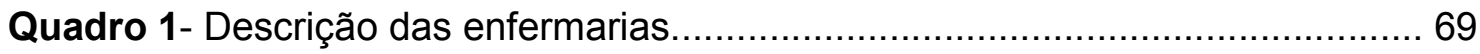

Quadro 2- Posicionamento no campo psiquiátrico............................................ 73

Quadro 3 - Posicionamento no campo religioso............................................. 116 


\section{SUMÁRIO}

INTRODUÇÃO

\section{PARTE I - CAMINHOS DA PESQUISA, APARATO TEÓRICO-METODOLÓGICO, METODOLOGIA OPERACIONAL E DELIMITAÇÃO DO RECORTE EMPÍRICO}

1 CAMINHOS DA PESQUISA E APARATO TEÓRICO-METODOLÓGICO ...............6

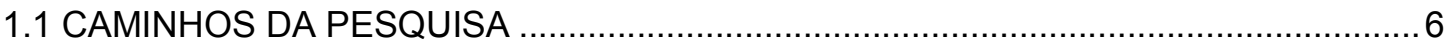

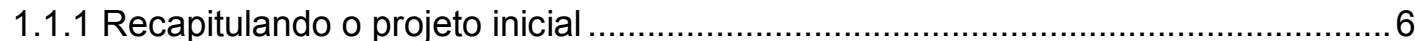

1.1.2 Por que estudar a relação ciência e religião? …………………………………. 9

1.1.3 Ciência e religião ............................................................................................ 10

1.1.4 Ciência-Médica e religião ........................................................................... 14

1.2 APARATO TEÓRICO METODOLÓGICO: A TEORIA SOCIOLÓGICA DE PIERRE

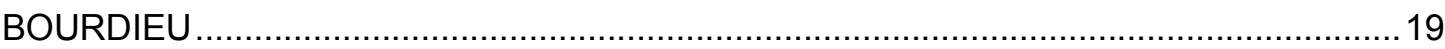

1.2.1 Construção conceitual à luz dos clássicos ........................................................19

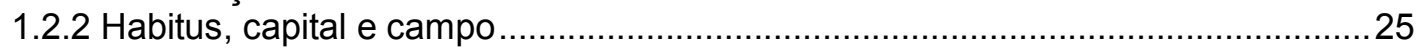

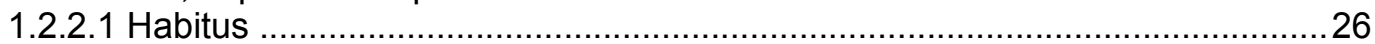

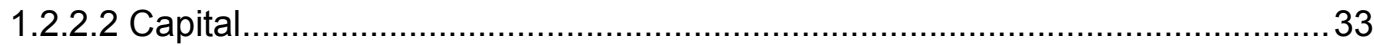

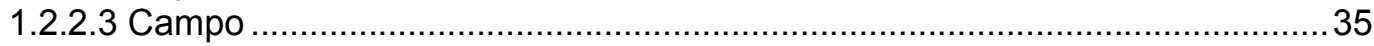

1.2.2.3.1 Campo religioso e Campo científico ..................................................42

2 DELIMITAÇÃO DO RECORTE EMPÍRICO E METODOLOGIA OPERACIONAL 46

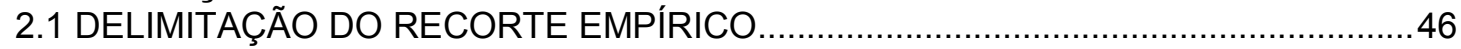

2.1.1 A medicina psiquiátrica como objeto da pesquisa ...............................................46

2.1.1.1 A psiquiatria no campo médico brasileiro ……………………………..... 49

2.1.1.2 Hospital das Clínicas da FMUSP (HCFMUSP) e Instituto de Psiquiatria (IPQ)

2.1.2 A capelania religiosa hospitalar como objeto de pesquisa

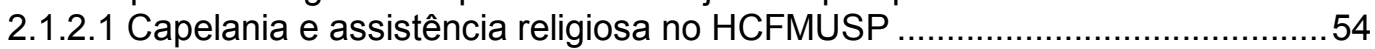

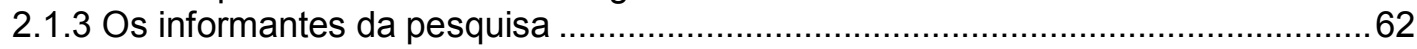

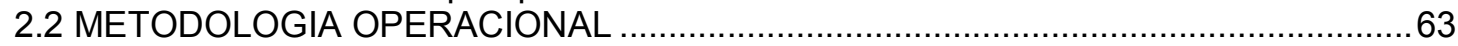

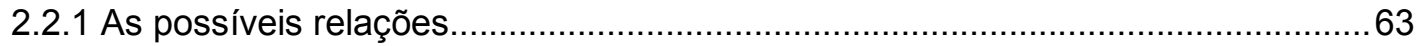

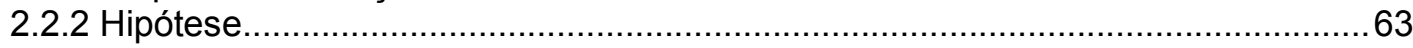

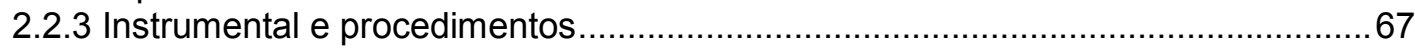

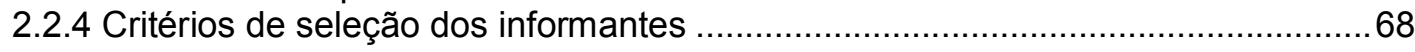

\section{PARTE II - CAMPO PSIQUIÁTRICO E CAMPO RELIGIOSO: MORFOLOGIAS}

3 MODELO PSIQUIÁTRICO ATUAL....................................................................72

3.1 POSICIONAMENTO DO PSIQUIATRA NO CAMPO PSIQUIÁTRICO .......................72

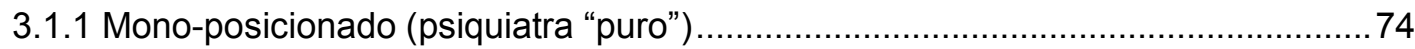

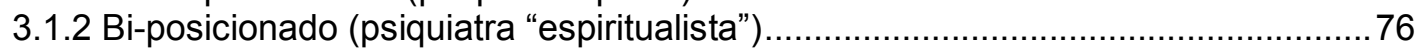

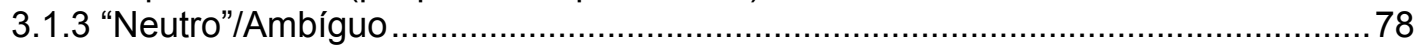

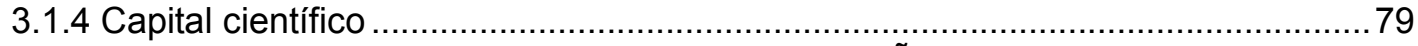

3.2 INSTITUTO DE PSIQUIATRIA (IPQ): A CONSTITUIÇÃO ATUAL ........................... 84

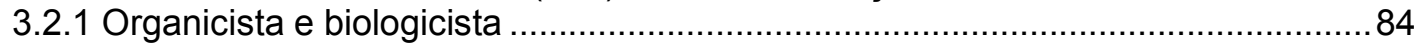

3.2.2 Formação médica: humanismo versus superespecialização................................ 92

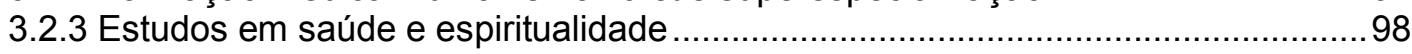

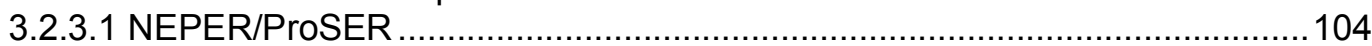




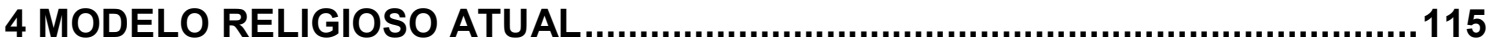

4.1 POSICIONAMENTO DO RELIGIOSO NO CAMPO RELIGIOSO...........................115

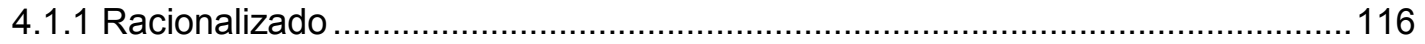

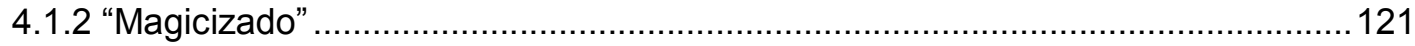

4.1.2.1 "Segunda lança" e segurança adicional ....................................................125

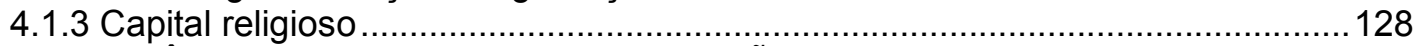

4.2 ASSISTÊNCIA RELIGIOSA: A CONSTITUIÇÃO ATUAL .......................................129

4.2.1 Monopólio e diversidade religiosa................................................................129

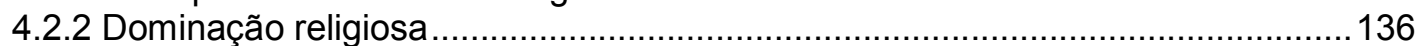

4.2.3 Posição sacerdotal central: estratégia ........................................................... 140

4.2.4 Dois modelos opostos de assistência religiosa ............................................... 144

PARTE III - CAMPO PSIQUIÁTRICO E CAMPO RELIGIOSO: PERCEPÇÕES

5. PERCEPÇÃO NO INTERIOR DO CAMPO PSIQUIÁTRICO ..............................151

5.1 PATOLOGIA PSIQUIÁTRICA E RELIGIOSIDADE …….....................................151

5.1.1 Normal versus patológico: questão cultural versus delírio ..................................151

5.1.2 Sintoma da doença versus Reestruturação da vida, dois sintagmas ...................172

5.1.2.1 Religião enquanto sintoma da doença: sintagma 1 …………………........178

5.1.2.2 Religião enquanto reestruturação da vida: sintagma 2 ...............................180

5.2 A RELIGIÃO DOS PSIQUIATRAS E A RELIGIÃO PARA OS PSIQUIATRAS ...........186

5.2.1 Religião, religiosidade ou espiritualidade? ....................................................190

5.2.2 Religião: esfera da intimidade ....................................................................... 194

5.2.3 Demanda religiosa e/ou demanda psiquiátrica? .............................................. 196

6 PERCEPÇÃO NO INTERIOR DO CAMPO RELIGIOSO .....................................201

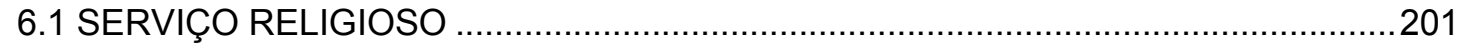

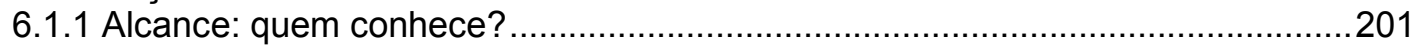

6.1.2 Atuação: casual e seletiva ..........................................................................202

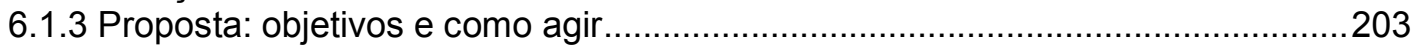

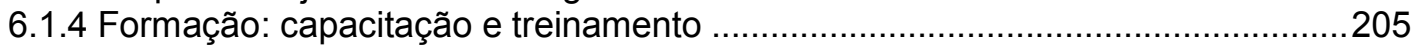

6.1.5 Pontos de vista: o olhar sobre a doença psiquiátrica........................................211

6.1.6 Convivência: relacionamento entre os agentes religiosos .................................213

6.1.7 Divisão do espaço: diversidade religiosa e conflito religioso ................................214

6.1.8 Práticas: contradição ....................................................................................217

\section{PARTE IV - CAMPO PSIQUIÁTRICO E CAMPO RELIGIOSO: RELAÇÕES}

7 RELAÇÃO ENTRE CAMPO PSIQUIÁTRICO E CAMPO RELIGIOSO ...............222

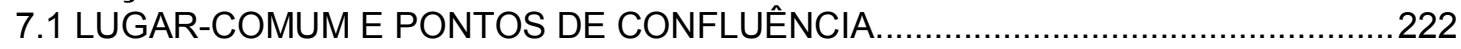

7.1.1 Paciente, imaterialidade e exclusão ……………………………………....222

7.1.2 O Médico e o seu dom: um poder (quase) religioso ………………………......225

7.2 DOXA NO(S) CAMPO(S): A "VERDADE" SOBRE O OUTRO ……........................2.

7.2.1 A "verdade" dos psiquiatras sobre o campo religioso ………………………......236

7.2.2 A "verdade" dos religiosos sobre o campo psiquiátrico.........................................224

7.3 DUPLA RELAÇÃO: INVASÃO OU RETRADUÇÃO NO CAMPO? ............................24

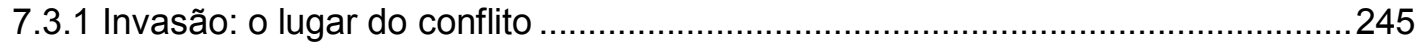

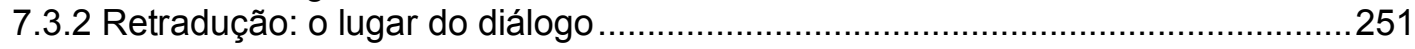

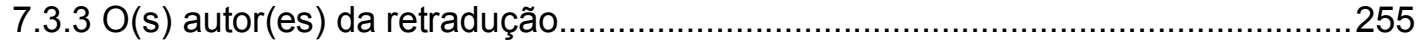


8 RELAÇÃO PARA COM O(S) CAMPO(S): O PACIENTE.....................................260

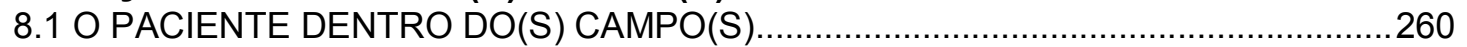

8.1.1 O paciente dentro do campo psiquiátrico: a verdade dos pacientes sobre os psiquiatras

8.1.2 O paciente dentro do campo religioso: a verdade dos pacientes sobre os religiosos

8.1.2.1 Religião do paciente e para o paciente

8.1.3 O espiritual e o psiquiátrico: qual a "verdade(ira)" demanda?

2 NECESSIDADES, DESEJOS, PERDA DE IDENTIDADE

CONSIDERAÇÕES FINAIS

279

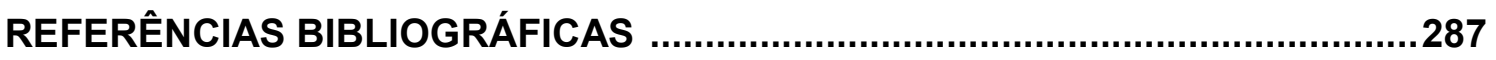

APÊNDICE - Roteiros de entrevistas.......................................................296

ANEXO - Parecer da CAPPesq (Comissão de Ética para Análise de projetos de pesquisa). 


\section{INTRODUÇÃO}

O escopo deste trabalho é revisitar a discussão tão antiga, não obstante atual sobre a relação entre ciência e religião. Se, por um lado, pode parecer contrassenso trazer à tona tal discussão (que aparentemente mostra-se já resolvida quanto ao lugar ocupado por cada um desses domínios), por outro lado, a realidade apresenta veredicto diverso: nos momentos em que o mundo científico e o mundo religioso são colocados em contato (pelos sujeitos que deles fazem parte) uma dinâmica de embates, concessões, junções é levada a cabo. A relação entre ciência e religião poderá muito provavelmente encerrar anfibologias, porquanto, o que as separam, para além de aspectos relacionados ao espaço de atuação de cada uma, são fronteiras simbólicas, as quais se encontram sujeitas à fluidez e a acomodações. Isso faz com que se reconsidere essa problemática e se adentre em mundos peculiares como o da medicina psiquiátrica e o da capelania hospitalar de uma reconhecida instituição como o Hospital das Clínicas da Faculdade de Medicina da USP (HCFMUSP). Nessa direção, a quinta-essência deste trabalho é examinar se ocorre, no interior do espaço hospitalar, uma luta simbólica entre psiquiatras e ministros religiosos e dentro de cada um desses domínios entre os seus respectivos especialistas. Todas essas relações podem ser pensadas pelo viés sociológico proposto por Bourdieu quando fala em conflito entre campos sociais e em conflito interno a um determinado campo.

A ousadia em realizar semelhante projeto pode parecer grande, todavia, está calcada na necessidade concreta de contribuir para a reflexão em torno de quem (a ciência ou a religião) tem a licença para atuar na vida humana. Tratar de tema tão polêmico é estar na berlinda e suscitar indignações, tanto do lado dos defensores do saber científico tout court quanto do lado daqueles que se posicionam a favor do saber religioso e suas benesses. Já aos que ocupam uma posição não de resistência, mas de compreensão dos imponderáveis de uma relação como esta, esses provavelmente não serão acometidos por qualquer tipo de estranhamento e compartilharão de observações e reflexões singulares. É preciso salientar a importância deste trabalho aos que procuram entrar em contato, para além da 
dureza dos conceitos, com as visões de mundo (consideradas aqui a partir das posições de cada agente) e suas implicações na vida dos indivíduos.

Ocupar-se de campos de atuação distintos, como o científico e o religioso, pode parecer antitético quando se empreende compartilhar com o leitor algo mais que a identificação das posições sociais ocupadas pelos indivíduos nesses dois domínios $^{1}$. Para além disso, é imperativo encaminhar-se a ultrapassar esse objetivo e procurar alcançar o significado dessas posições na vida dos agentes sociais aqui analisados $^{2}$. No interior de uma análise sobre as relações entre campos é possível atinar com questões outras, como as demandas e as ofertas de sentido que acompanham os diferentes sujeitos, mormente quando estes se deparam com os imponderáveis da vida em sociedade.

É oportuno falar aqui do modo como o texto foi construído. Como será possível observar, abusou-se da utilização de trechos das entrevistas - pertinentes aos diferentes títulos e subtítulos da tese - por considerá-los indispensáveis à visualização da problemática. Ou seja, no texto, os trechos que o intercalam são vistos como imprescindíveis. Semelhante metodologia não minimizou o trabalho, muito pelo contrário, a seleção dos fragmentos (sua sistematização e organização) e o seu devido manuseio demandaram tempo, o que resultou, consequentemente, em árduo empreendimento. Desse modo, os trechos de entrevistas neste trabalho devem ser vistos como fazendo parte do próprio corpo do texto, não se encontram isolados deste no sentido de serem recursos destacados para mera elucidação e ilustração. Assim procedendo, esta tese foi conduzida de forma que "o objeto de estudo reveste, impregna e entranha todo o texto" (MINAYO, 2007, p. 359, destaque da autora). Obviamente, devido à grande quantidade de depoimentos interessantes, mostrou-se necessário selecionar aqueles que eram os mais paradigmáticos em relação à temática abordada em cada momento. Essa escolha não ocorreu com facilidade, pois todos os diversos fragmentos das entrevistas eram preciosos e tinham muito a dizer. Entretanto, por uma questão operacional, a eleição de alguns trechos e a exclusão de outros foram necessárias.

\footnotetext{
${ }^{1}$ A proposta bourdieusiana aqui compartilhada dá ênfase às posições ocupadas pelos agentes nos diferentes campos sociais.

${ }^{2}$ As posições sociais (relacionadas à detenção de maior ou menor capital e, portanto, à localização no polo dominante ou dominado de determinado campo) são centrais na teoria de Bourdieu. Entretanto, voltar-se-á atenção aqui às tomadas de posição (posicionamentos como se denominará neste estudo) resultantes de uma posição social ocupada.
} 
Trata-se de conflitos/relações e acredita-se ser na fala dos sujeitos que eles vêm a se expressar, compartilhando igualmente com Minayo (2007, p. 205, aspas da autora) da ideia de que "por meio da comunicação verbal - que é inseparável de outras formas de comunicação - as pessoas 'refletem e refratam' conflitos e contradições [...]". O que será colocado em relevo neste estudo são as diferentes posições e as tomadas de posição que delas resultam - apenas por uma questão de opção de análise, não se desacredita na importância das interações, das relações intersubjetivas -, por isso, nada mais valioso que a palavra daqueles que são os sujeitos empíricos: especialistas da saúde mental, especialistas religiosos e pacientes. O que se quer enfatizar é que os discursos são muito importantes nesta reflexão sobre a relação entre os campos, porém, eles não falam por si mesmo. Numa concepção mais heurística, os discursos são interessantes, mas para compreendê-los é necessário colocá-los em relação às posições.

Trabalhar com tamanha intensidade o material empírico não significa o menosprezo pelo arcabouço teórico. Para este também se considera dar a devida atenção, dispensando-Ihe espaço significativo no corpo deste trabalho. Ao assim proceder, por sua vez, a intenção não é abordá-lo descoladamente do material empírico. Procura-se, ao contrário, colocá-los em constante diálogo ao longo de todo o trabalho. Se uma exegese inicial da teoria de Bourdieu é realizada é para, a partir dela, colocar insights quando do contato com o material empírico.

Enfim, a intenção é evitar "tanto o endeusamento teórico como a reificação da realidade empírica" (MINAYO, 2007, p. 45), pois tanto um como o outro parecem ser atitudes que comprometem a realização de um trabalho satisfatório. Nem o menosprezo pelo material empírico, nem a "redução da verdade à dimensão dos acontecimentos localizados" (IBIDEM) podem ser postos a serviço de um empreendimento que procura expor com acuidade a realidade social. Assim é considerado.

Esta tese de doutorado apresenta um formato que, acredita-se, torna possível uma melhor compreensão e apreensão de seus objetivos. Ela compõe-se da seguinte estrutura: Caminhos da pesquisa, Aparato teórico-metodológico, Delimitação do recorte empírico, Metodologia operacional (PARTE I), Campo Psiquiátrico e Campo Religioso: Morfologias (PARTE II), Campo Psiquiátrico e 
Campo Religioso: Percepções (PARTE III), Campo Psiquiátrico e Campo Religioso: Relações (PARTE IV).

A PARTE I contém dois capítulos. No primeiro, discorre-se sobre os caminhos percorridos ao longo da pesquisa e o instrumental teórico-metodológico utilizado. Já o segundo capítulo trata da delimitação do recorte empírico e da metodologia operacional: é elucidado como foi realizada a pesquisa, os procedimentos, discorre-se sobre o histórico do Hospital das Clínicas da Faculdade de Medicina da USP (HCFMUSP) e do Instituto de Psiquiatria (IPQ) ${ }^{3}$ e são apresentados os informantes da pesquisa. Neste momento são visualizadas as possíveis relações e exibida a hipótese levantada inicialmente neste estudo.

Nas demais PARTES (II, III, IV) desenvolvem-se as reflexões feitas a partir do material empírico. Algumas categorias de análise foram compostas mediante as entrevistas realizadas e nomearão os demais capítulos desta tese. São eles: PARTE II (3. Modelo Psiquiátrico Atual; 4. Modelo Religioso Atual); PARTE III (5. Percepção no interior do campo psiquiátrico; 6. Percepção no interior do campo religioso); PARTE IV (7. Relação entre campo psiquiátrico e campo religioso; 8. Relação para com o(s) campo(s): o paciente). Em cada um deles é possível fazer apontamentos pertinentes e lançar questões importantes ao tratamento da hipótese quanto à relação ciência/religião.

\footnotetext{
${ }^{3}$ A partir de agora quando forem referidos o Hospital das Clínicas da Faculdade de Medicina da USP e o Instituto de Psiquiatria serão utilizadas as siglas HCFMUSP e IPQ, respectivamente.
} 
PARTE I - CAMINHOS DA PESQUISA, APARATO TEÓRICOMETODOLÓGICO, METODOLOGIA OPERACIONAL E DELIMITAČ̃̃O DO RECORTE EMPÍRICO 


\section{CAMINHOS DA PESQUISA E APARATO TEÓRICO- METODOLÓGICO}

[...] a construção do objeto - pelo menos na minha experiência de investigador - não é uma coisa que se produza de uma assentada, por uma espécie de acto teórico inaugural, e o programa de observações ou de análises por meio do qual a operação se efectua não é um plano que se desenhe antecipadamente, à maneira de um engenheiro: é um trabalho de grande fôlego, que se realiza pouco a pouco, por retoques sucessivos, por toda uma série de correcções, de emendas, sugeridos por o que se chama o ofício, quer dizer, esse conjunto de princípios práticos que orientam as opções ao mesmo tempo minúsculas e decisivas. (O poder simbólico, Pierre Bourdieu).

\subsection{CAMINHOS DA PESQUISA}

\subsubsection{Recapitulando o projeto inicial ${ }^{4}$}

Inicialmente pretende-se realizar uma retomada do projeto de pesquisa, dando a conhecer quais foram as questões norteadoras do trabalho e como se iniciou todo o processo de investigação (o porquê da escolha do tema, as suspeitas, constatações e metas iniciais). Associado a isso será necessário resgatar algumas reflexões anteriormente abordadas no projeto relativas ao binômio ciência/religião, evidenciando como ele tem sido tratado pelos estudiosos e qual a relevância de estudá-lo atualmente.

\footnotetext{
${ }^{4} \mathrm{O}$ título inicial deste trabalho era "A relação entre ministros religiosos, médicos e pacientes no Instituto de Psiquiatria (IPQ) do Hospital das Clínicas da Faculdade de Medicina da USP (HCFMUSP)".
} 
Este trabalho nasceu da suspeita, por um lado, de que o IPQ, mediante alguns de seus profissionais ${ }^{5}$, estaria proporcionando maior abertura ao tratamento da temática religiosa, estabelecendo com ela diálogos e aproximações ${ }^{6}$ (atitude que, com base na teoria de "campo" de Bourdieu, supõe-se colocar em risco a autonomia do campo psiquiátrico). Por outro lado, da constatação de que parece ocorrer uma influência do discurso científico sobre o discurso religioso (situação que pode explicar a tolerância à presença religiosa no meio psiquiátrico). Essa realidade pôde ser apreciada no fato de haver ministros religiosos que se mostram dispostos a trabalhar de acordo com as normas científicas, de modo a construírem um discurso, por intermédio do qual procuram colocar enfaticamente a prioridade atual que as explicações científicas têm na área médica em detrimento das religiosas. Essas duas constatações iniciais revelavam ser necessário dar continuidade a uma pesquisa mais aprofundada. São elas as duas vertentes que estruturam este trabalho e em função das quais são realizadas as análises.

A ideia inicial do projeto de pesquisa, então, era o de avaliar em que moldes ocorreria a relação tão atual entre ciência e religião. Essa avaliação seria feita por meio da identificação do tipo de relação entre a psiquiatria e a religião. Os portavozes seriam, do lado da psiquiatria, os psiquiatras e enfermeiros e, do lado da religião, os ministros religiosos que faziam parte da capelania religiosa do HCFMUSP, composta pelos serviços religiosos católico e evangélico.

A despeito da demarcação de territórios e da separação tão clara de competências que tão acentuadamente quer fazer-se crer, era possível constatar (mesmo prematuramente) a ocorrência de uma aproximação, a qual seria um tanto quanto inusitada, porquanto um abismo sempre se interpôs entre ciência e religião, resultado de objetivos claramente opostos: razão e fé.

Pretendia-se, por isso, mediante a teoria de campo proposta por Pierre Bourdieu, que trata do funcionamento interno de diferentes campos sociais e as

\footnotetext{
${ }^{5}$ Por intermédio de pesquisa preliminar foi possível perceber a existência de alguns psiquiatras no IPQ sensíveis à questão da importância da religiosidade no tratamento das doenças que faziam a ponte entre o discurso científico e o discurso religioso.

Fato este que pode ser confirmado em vista das seguintes atuações: a criação do NEPER (Núcleo de Estudos em Problemas Espirituais e Religiosos, atualmente denominado ProSER), a realização de pesquisas vinculadas a esse núcleo e, mais recentemente, a possível oficialização dele como o responsável por proporcionar auxílio no sentido de acompanhar as atividades de assistência espiritual realizadas pelos religiosos, criando para isso programas.
} 
relações de poder que se travam entre eles, verificar em que nível dar-se-iam as relações entre o campo psiquiátrico e o campo religioso.

Malgrado o tipo de diálogo que poderia ocorrer entre eles, seria primordial verificar até que ponto tal aproximação existe e é mantida, de forma a não conduzir a conflitos sobre o lugar que cada um ocupa e a sua especialidade. Isso levando em consideração duas asserções: a primeira quanto ao fato de os produtores de um determinado campo ${ }^{7}$ só reconhecerem como clientes seus próprios concorrentes, o que faz com que o valor de um produto só seja reconhecido por outro produtor do mesmo campo (BOURDIEU, 1983a) ${ }^{8}$. A outra, de que "aquele que faz apelo a uma autoridade exterior ao campo só pode atrair sobre si o descrédito" (IBIDEM).

De posse dessas questões, a meta de execução do projeto passava pelos seguintes eixos principais: a análise de dois tipos de relações. De um lado, a relação estabelecida entre especialistas da religião e especialistas da saúde mental. De outro lado, a relação desses dois tipos de especialista com os leigos que aqui, no caso, seriam os pacientes (leigos em relação tanto ao saber religioso quanto ao saber médico), visto que estes seriam o motivo tanto dos investimentos psiquiátricos quanto dos investimentos religiosos, bem como das disputas e/ou relações entre os dois domínios.

Desses eixos centrais, outras questões impuseram-se enquanto características importantes a serem deslindadas: as relações internas a cada campo. Ou seja, parecia interessante saber qual o tipo de relação, como é a convivência: 1) dos religiosos (católicos, protestantes, e porventura outros que houvesse) entre si ; 2) dos médicos (os "sensíveis" e os "não sensíveis" à questão religiosa no hospital).

\footnotetext{
${ }^{7}$ Nesse caso, Bourdieu, refere-se, especificamente, ao campo científico.

${ }^{8} \mathrm{O}$ autor trata dessas questões em obras destinadas ao estudo do campo científico como "Le champ scientifique. Actes de la recherché en sciences sociales, n. 2-3, p. 88-104, juin 1976; e também em "La spécificité du champ scientifique et les conditions sociales du progrès de la raison". Sociologie et societés, v. VII, n. 1, p. 91-118, mai 1975. Nessas obras, Bourdieu irá reagir à visão, colocada em prática pela sociologia da ciência, "conciliadora da 'comunidade científica". Ao romper com essa perspectiva, ele introduz conceitos como o de campo científico e capital científico. Nessa direção, ele irá mostrar que "a lógica desse mercado - no qual, no limite, pode-se, como nas matemáticas avançadas, ter por clientes apenas os seus piores concorrentes - é favorável ao progresso da razão" (BOURDIEU, 2004a, p.12).
} 


\subsubsection{Por que estudar a relação ciência e religião?}

Até o momento, pouco conhecimento se tem sobre as relações que os especialistas da religião estabelecem com os especialistas de outros setores da vida social. O que se sabe a partir de Max Weber (1963, p. 400) é que a relação existente entre a esfera religiosa e as demais, principalmente a intelectual, é muito conflituosa e marcante. Segundo esse autor, "a tensão, autoconsciente, da religião é a maior, e mais fundamentada em princípios, quando a religião enfrenta a esfera do conhecimento intelectual" (IBIDEM). Ética e mundo - como bem mostrou Weber em seu texto Rejeições religiosas do mundo e suas direções - são duas ordens de vida que estão constantemente em disputa pela hegemonia.

Com o advento da modernidade, as esferas intelectual, política, erótica, econômica e estética alcançaram legitimidade tal qual a esfera religiosa e hoje, mais do que nunca, seguem mediante suas legalidades próprias a demarcar sempre mais o seu território de atuação. Entretanto, apesar da legalidade que lhes é própria e do formato particular assumido por cada uma delas, elas poderão, em alguns momentos, entrar em contato entre si por intermédio dos agentes que têm nelas múltiplas participações. Tal fato pode ocorrer de duas formas: ou pela atuação concomitante em mais de uma esfera ou pelos agentes proporcionarem o contato entre elas sob a forma de um diálogo que se caracteriza a um só tempo como espaço de concorrência e, paradoxalmente, de união.

Houve um tempo em que os universos sociais (o religioso, o econômico, o artístico, o intelectual) não eram distintos, compunham o todo e não se diferenciavam nele. Com a evolução das sociedades, essa situação mudou para uma outra, de universos diferenciados ${ }^{9}$, autônomos, com leis próprias que são frequentemente tautologias (no campo econômico: negócios são negócios; no campo artístico: a arte pela arte) (BOURDIEU, 1996b, 147-148). Existe em cada "campo" 10 , pode perceber-se, uma lei fundamental, independente de outros campos.

\footnotetext{
${ }^{9}$ Segundo Bourdieu (1996b, p. 147), na fundamentação da teoria dos campos é possível constatar que o mundo social é o lugar onde ocorre um processo de diferenciação progressiva. Tal constatação não é nova. Segundo o autor, já podia ser encontrada em Spencer, Durkheim, Weber.

${ }^{10}$ É importante lembrar que, para Bourdieu, a noção de campo refere-se ao espaço onde as posições dos agentes estão a priori fixadas. Além disso, ele é definido como o local em que acontece uma luta concorrencial em função de interesses específicos que distinguem determinada área de atuação. $O$
} 
Cada um deles avalia as questões que estão em jogo "de acordo com princípios e critérios irredutíveis aos de outros universos" (BOURDIEU, 1996b, 147-148). Por não ser mais a religião o universo por meio do qual se ditam as regras do bem viver, é impossível não perceber que outros "campos" de atuação deixam suas marcas e procuram autoafirmar-se.

Campos com objetivos tão distintos atualmente, mas que num dado momento compartilharam o mesmo espaço, religião e ciência buscam reaproximarse em situações diversas. A iniciativa de reconciliação parece acontecer vinda de ambas as partes, tanto dos cientistas quanto dos religiosos. Tal reaproximação precisa ser colocada em pauta e apreciada para que tanto os homens de ciência quanto os homens de religião reavaliem as suas posições bem como as suas tomadas de posição e de que forma elas reverberam na sociedade atual.

\subsubsection{Ciência e religião}

Ainda que de forma precária, atualmente, a maior parte da população possui acesso à ciência e pode gozar de seus benefícios. Mesmo que esse acesso não seja o único caminho encontrado, podendo haver o uso concomitante de recursos científicos e recursos religiosos, é impossível não admitir os avanços da ciência e os recursos que ela proporciona a todos. Pode ocorrer, por vezes, que em determinados momentos o modelo científico não seja exclusivo na vida das pessoas.

campo, para ele, é prefigurado em suas determinações sobre a ação de seus protagonistas, ou seja, estruturado e estruturante, o que não faz parte da perspectiva weberiana. Reporta-se a Weber em alguns momentos por ser ele um dos autores clássicos da sociologia, com o qual Bourdieu mantém diálogo profundo ao longo de sua obra. Atenta-se às diferenças que os separam, entretanto não se considera inviável colocá-los em diálogo em alguns momentos, pois apesar de possuírem perspectivas metodológicas diferentes, trazem reflexões importantes ao tema aqui proposto. 
Tal constatação evidencia que, mesmo com o desencantamento do mundo ${ }^{11}$, ainda resta um espaço para a manifestação da religião e das práticas mágicas ${ }^{12}$.

A busca de auxílio em dois mundos tão diferentes encontra explicação plausível no fato de que o homem moderno, em toda a sua complexidade, refere necessidades outras que não somente aquelas respondidas pelo conhecimento técnico-científico. Ou seja, frequentemente a religião é retomada como um recurso quando a busca humana por respostas ultrapassa o âmbito da técnica e das relações possíveis. Neste momento, as modernas técnicas científicas passam a ser utilizadas em conjunto com "poderes sobrenaturais", os quais acabam por proporcionar uma maior eficácia em algumas situações.

Dentro das dimensões de espaço e tempo, a religião tem sido um dos relevantes fenômenos explicativos das indagações dos seres humanos sobre os significados da existência individual e grupal. [...]

${ }^{11}$ Segundo Max Weber (1993, p. 30), desencantamento do mundo é a descoberta de que o mundo não pode ser mudado pela magia, e pode ser dominado por meio da técnica: "A intelectualização e a racionalização [...] significam [...] que podemos dominar tudo, por meio da previsão. Equivale isso a despojar de magia o mundo". Atualmente, alguns estudos mostram haver dois sentidos (que não são evolutivos na obra de Weber, nela podem aparecer simultaneamente) para desencantamento do mundo: desencantamento enquanto desmagificação e desencantamento enquanto perda de sentido. São dois momentos que podem aparecer concomitantemente na obra weberiana. Entretanto, do ponto de vista da historicidade, eles são diversos: um primeiro momento é o desencantamento do mundo pela religião e um segundo momento é o desencantamento do mundo pela ciência (secularização), onde esta assume o papel anteriormente assumido pela religião (PIERUCCI, 2003).

${ }^{12}$ Quando se refere à religião e à magia, não se pode deixar de mostrar em que nível essas duas diferenciam-se ou aproximam-se. Weber (1994), por exemplo, insistentemente afirma existir uma fluidez na separação entre as duas. Ele não descarta a magia do universo religioso, ela seria na verdade uma primeira forma de expressão do religioso que implicaria uma relação diversa no que diz respeito ao divino. Quando fala do protestantismo, o autor mostra, em alguma medida, a magia presente no catolicismo (com os rituais, os sacramentos, a venda de indulgências). Ou seja, embora Weber faça a distinção em termos típico-ideais, existe na prática a associação de ambas. Para esse autor, assim como em todos os fenômenos sociológicos, a oposição entre sacerdote, mago e profeta é bastante fluida, pois apesar desses tipos serem unívocos, existem entre os seus extremos casos intermediários, podendo ocorrer que a oposição entre eles, apesar de teoricamente nítida, na realidade se constitua de forma fluida. Nas distinções elaboradas pelo autor, o sacerdote e o mago são denominados funcionários profissionais da fé, ambos se diferenciando apenas no seguinte aspecto: o primeiro utiliza sua profissão para influenciar deuses, enquanto o outro para forçar demônios. Segundo Bourdieu (1999, p.45), a maior parte dos autores reconhece os seguintes traços nas práticas mágicas: visam a objetivos concretos e específicos, parciais e imediatos (em oposição aos objetivos mais abstratos, mais genéricos e mais distantes que seriam os da religião); estão inspiradas pela intenção de coerção ou de manipulação dos poderes sobrenaturais (em oposição às disposições propiciatórias e contemplativas da 'oração', por exemplo); e por último, encontram-se fechadas no formalismo e no ritualismo do toma lá dá cá (aspas e destaque do autor). Para finalizar, trata-se, em relação à magia e à religião, de lógicas diferentes: na primeira, acredita-se ser o universo regido por forças, as quais podem, de alguma maneira, ser manipuladas por algum especialista. Já com relação às religiões cristãs, faz-se referência ao milagre, o qual seria a ruptura das leis naturais por uma força superior. Segundo Concone (2003, p. 53-54), ao contrário de um universo em que coisas visíveis e forças invisíveis estão em relação e comunicação constante, o milagre entendido como "uma intervenção extraordinária na ordem natural do mundo [...] pode se instaurar como ruptura extraordinária [somente] num quadro de aceitação de leis naturais impessoais". 
Hoje todas as modalidades de conhecimento convivem concomitantemente, buscando soluções para dramas humanos e para o avanço da humanidade. Uma delas é hegemônica; a Ciência. Entretanto, [mesmo com seus esquemas de explicações dominantes] nem por isso, seu arcabouço explicativo é exclusivo e conclusivo. (MINAYO, 2007, p. 48, destaque da autora).

A religião consorciada à ciência pode ser entendida como uma segurança adicional $^{13}$, sem que a qualificação desta última seja posta em questão. Se, por um lado, esse processo poderia ser tido como contraditório, por outro lado, a presença do sagrado no espaço da modernidade, segundo Silva (1995, p. 31), deve ser encarado de forma diferente, como algo factível:

A reinscrição do sagrado (selvagem, instituído, mágico ou religioso) no espaço social da metrópole, convivendo ao lado do pensamento racional, utilitário, manipulador e secular, não se realiza enquanto contradição (ou um corte a ser superado).

Nessa perspectiva, acredita-se não ser mais possível à ciência ignorar totalmente a religião, assim como não é possível que a religião ignore totalmente o pensamento mágico, ao qual também se recorre quando o religioso instituído não produz um conteúdo plausível. Aliás, o conhecimento científico e a sua tentativa de racionalizar todos os setores da vida não colocaram fim à busca de elementos mágicos como solução ao sofrimento tendo em vista a complexidade da vida, a qual não pode ser entendida apenas mediante simples modelos (SCHWEICKARDT, 2002, p. 89).

Desse ponto de vista, trata-se, ao contrário, de perceber-se, na realidade brasileira em questão, ciência e religião como formas distintas, porém, passíveis de convivência, pois, enquanto linguagens simbólicas, só existem na medida em que continuam a representar eficazmente a realidade e a proporcionar modelos que orientem a conduta dos indivíduos, dando-lhes meios para entender o mundo como ele é ou como deveria ser (SILVA, 1995, p. 31).

Embora a ciência, atualmente, seja considerada "a forma hegemônica de construção do conhecimento" (MINAYO, 2007, p. 35), chegando mesmo a ser vista "como um novo mito da atualidade por causa de sua pretensão de ser o único motor

${ }^{13}$ Evans-Pritchard (1978) percebe, como se verá detalhadamente em outro momento, nos seus estudos sobre os Azande que, para estes, os elementos mágicos proporcionariam uma garantia adicional ao empreendimento empírico. 
e critério de verdade" (IBIDEM), tende-se a concordar com a autora quanto ao fato de que "desde tempos imemoriais, as religiões, a filosofia, os mitos, a poesia e a arte têm sido instrumentos poderosos de conhecimento" (IBIDEM). Ou seja, formas diversas de saber, em outros tempos, deram conta das incertezas e angústias humanas.

E, para finalizar, ainda que a ciência não assuma o status de crença normalmente atribuído às religiões - ela não deixa de se caracterizar como tal, na medida em que se constitui enquanto um modelo com "regras universais e padrões rígidos permitindo uma linguagem comum divulgada e conhecida no mundo inteiro" (MINAYO, 2007, p. 36) que dita as regras do bem viver ${ }^{14}$ tal como um dia o fez (ou faz) o modelo religioso. O que conduz Laplantine (2004, p. 238) a afirmar que "se creditando a uma pretensão decididamente totalizante", a medicina é "nossa religião". No fundo, e é uma realidade que salta aos olhos, quanto mais esforços a ciência médica desdobra para "excluir de sua prática processos mágico-religiosos" (QUINTANA, 1999, p. 38), mais ela tem a aspiração de ocupar esse mesmo lugar (no sentido de a saúde ocupar o lugar anteriormente ocupado pela salvação) (IBIDEM).

Tal como a comunidade religiosa (que crê nos seus dogmas, mitos, ritos), a comunidade científica, identificada por Popper (1973 apud Minayo, 2007, p. 36) como o Terceiro mundo, tem lá as suas tradições e simbologias e a elas faz reverência: "Os cientistas aceitam as condições instituídas e, ao mesmo tempo, o caráter de historicidade e provisoriedade peculiar do universo em que decidiram investir sua vida" (MINAYO, 2007, p. 36). Trata-se, no fundo, de dois modelos de crença, sendo que a ciência atualmente é o modelo dominante em oposição ao(s) modelo (s) religioso (s).

\footnotetext{
${ }^{14}$ Segundo Laplantine (2004, p. 237, destaques e aspas do autor), a medicina ocidental - ao buscar não apenas o que é verdadeiro, mas também o que é bom - torna-se o saber por excelência, aquele que dita as normas das condutas e estende seu monopólio bem além da linha de demarcação do domínio biológico: "É ela que ordena (a 'disposição médica'), prescreve (a 'prescrição médica'), certifica (a 'certidão médica'), [...] promete (e a esperança suscitada [...] é imensa, uma vez que induz muitos a acreditarem que todas as doenças poderão ser vencidas)".
} 


\subsubsection{Ciência-Médica e religião}

Em termos semelhantes aos expostos anteriormente, é possível pensar a relação entre a medicina e a religião. Na medida em que a ciência médica por si só não tem competência para dar respostas suficientes à questão do sofrimento ${ }^{15}$, ela deixa em aberto uma questão que é elementar na concepção do enfermo: "Por que eu estou doente?". Foi Max Weber (1994, p. 335) quem primeiro remeteu à questão do sofrimento como elemento basilar de certas religiões. O autor fala da teodicéia do sofrimento ${ }^{16}$. Nesse conceito, as religiões justificariam a vida concreta dos indivíduos em sociedade:

[...] quase toda religiosidade ética das camadas positivamente privilegiadas e dos sacerdotes a seu serviço considera a situação social do indivíduo positivamente ou negativamente privilegiado algo religiosamente merecido, e variam somente as formas de legitimação da situação feliz. [...] Inversamente correspondente a essa situação é a dos negativamente privilegiados. Sua necessidade específica é a salvação do sofrimento.

Em outras palavras, a vida terrena precisa ter uma justificativa, pois o sofrimento faz parte do destino de certos homens. Entre os males causadores do sofrimento fazem parte as doenças, as quais necessitam de explicações que podem ser obtidas por meio de modelos teológicos. Tais modelos proporcionariam respostas relativas à origem e aos motivos que conduzem às situações tidas como patológicas (MONTERO, 1985). De outro modo, é possível afirmar que enquanto o saber médico explica "o 'como' das moléstias", as terapias religiosas "procuram responder ao 'por quê' das enfermidades" (IBIDEM). Sob essa perspectiva, a religião

\footnotetext{
${ }^{15}$ Até mesmo porque talvez não seja esta a sua função: dar explicações outras para o sofrimento que não explicações técnico-científicas.

${ }^{16}$ Ao interpretar a obra de Max Weber, Bourdieu (1999, p. 49) questiona a adequação do termo usado pelo autor que, segundo ele, não leva em conta a realidade das classes sociais diferenciadas. Bourdieu propõe substituí-lo pelo termo sociodicéia, por ele cunhado. Com isso, o autor, diferentemente de Weber, procura mostrar que a importância da religião não reside apenas na questão da resolução de problemas relativos às condições de existência. A religião, para além disso, cumpre função de legitimação das diferentes posições sociais. Entretanto, é necessário que se faça justiça a Weber com relação a tais críticas, pois, ao contrário do que sugere Bourdieu, nas leituras dos escritos de sociologia da religião sempre se nota um Weber preocupado em relacionar as teodicéias às condições sociais de seus agentes. É o que transparece na teodicéia da felicidade e na teodicéia do sofrimento tratadas pelo autor. A primeira constituída por ricos e felizes com uma demanda por legitimação e a segunda composta por pobres e infelizes demandando salvação (WEBER, 1994).
} 
possibilitaria ao enfermo resgatar a questão do sentido último ${ }^{17}$, da razão pela qual determinada enfermidade recaiu sobre ele e não sobre uma outra pessoa. Ou seja, cada uma desempenha um papel: enquanto a ciência propõe-se a explicar o sofrimento e a doença do ponto de vista técnico - "a ciência coloca naturalmente à nossa disposição certo número de conhecimentos que nos permitem dominar técnicamente a vida por meio da previsão" (WEBER, 1993, p. 45) -, a religião os explica de um ponto de vista existencial. A ciência não é doadora de sentido ${ }^{18}$; ao contrário, ela traduz justamente conhecimentos "capazes de extirpar, até às raízes, a crença na existência de seja lá o que for que se pareça a uma significação do mundo" (IBIDEM, p. 35). Associado à ideia de progresso, o que representa a ciência é o provisório, o inacabado, jamais o definitivo: "O homem civilizado [...] pode sentirse 'cansado' da vida, mas não pleno dela" (IBIDEM, p. 31, aspas do autor). Com essas considerações, é possível marcar com nitidez quais os elementos, particulares do mundo científico e do mundo religioso, são responsáveis pelo papel desempenhado por cada um desses.

A relação entre medicina e religião tem sido pensada sob diferentes aspectos. Um deles é aquele que trata da associação entre fé e cura. É forte a ideia de que essas duas últimas estejam associadas; aliás, não é nova a concepção de que a religião, ao estabelecer regras e atividades para evitar a doença e protelar a morte, influencia a duração da vida (LOTUFO-NETO, 1997, p 71). Pesquisas têm comprovado essa relação e têm revelado o quão ela é importante enquanto objeto de análise ${ }^{19}$. É o caso de um estudo, no qual foram avaliadas trezentas admissões consecutivas em uma enfermaria psiquiátrica da Universidade de Campinas. Ao relacionar a duração da internação com dezesseis variáveis clínicas e demográficas, os autores constataram que pacientes filiados às igrejas pentecostais apresentaram internações com duração menor do que os pacientes católicos (DALGALARRONDO;

\footnotetext{
${ }^{17}$ Sentido último no caso da religião. Já no caso da magia pode ser apenas um contágio ou influência maligna, que poderia ser ritualmente removido(a).

${ }^{18}$ Bem havia lembrado WEBER (1993, p. 47) que a ciência é, atualmente, uma vocação que se alicerça na especialização e que é colocada "a serviço de uma tomada de consciência de nós mesmos e do conhecimento das relações objetivas". De acordo com o autor, ao contrário do que se possa pensar, ela "não é produto de revelações, nem é graça que um profeta ou um visionário houvesse recebido para assegurar a salvação das almas; não é também porção integrante da meditação de sábios e filósofos que se dedicam a refletir sobre o sentido do mundo".

${ }_{19}$ Por outro lado, segundo Concone (informação verbal), é importante lembrar que a discussão contemporânea sobre placebo mostra que a crença/fé/confiança não é apanágio religioso. (informação fornecida pela Professora Dra Maria Helena Villas Boas Concone, em exame de qualificação de tese de doutorado).
} 
GATTAZ,1992). Semelhante resultado foi conferido a questões como: prática religiosa vigorosa, maior controle social e sistema de apoio mais satisfatório.

Outras reflexões foram feitas a respeito dessa relação. Num primeiro plano, ela foi pensada em termos econômicos, de modo que - apesar das diferenças entre medicina e religião - concluiu tratar-se em ambos os casos de modelos econômicos, através dos quais se comercializa a cura da enfermidade. Nessa perspectiva, tanto as instituições médicas quanto as religiosas "se organizam em termos empresariais, racionais, para vender serviços e mercadorias a uma clientela necessitada" (ALVES, 1984, p. 115). E mais: o fato de essas duas instituições encontrarem-se num mesmo nível "é a razão por que frequentemente se passa de uma empresa à outra [...] e esta passagem sugere que as duas desempenham as mesmas funções" (IBIDEM) ${ }^{20}$. Num segundo plano, pensou-se essa relação trazendo à tona o lado mais espiritual. Por essa via, acredita-se haver também uma aproximação entre os dois diferentes saberes (médico e religioso) que, em última instância, podem ser percebidos como tendo uma origem sacra. Tanto no Oriente quanto no Ocidente "o saber-agir do médico tinha muito de taumatúrgico" (LUZ, 200, p. 186, destaque da autora). O fato de tal saber ser originalmente tido como sagrado fazia com que quem o praticasse, por sua vez, possuísse "características sacerdotais" (IBIDEM). Resumindo: "A corporação médica, se se pode empregar sem anacronismo esta expressão para designar os terapeutas desde essa época, tinha literalmente na arte da cura seu sacerdócio" (IBIDEM, destaque da autora). O caráter sagrado atribuído ao médico parece bem atual. Ao observar tanto a prática desses profissionais quanto o modo como os pacientes a eles se dirigem, pode-se perceber que existe algo que transcende o contato comum entre os mortais.

Ao falar de uma origem sagrada do conhecimento médico, é necessário lembrar que Durkheim (1989, p. 507) já havia tratado da questão da origem religiosa da ciência em As formas elementares de vida religiosa. Em seu texto, o autor utiliza argumentos para evidenciar como o conhecimento científico está fundado na

\footnotetext{
${ }^{20}$ O autor faz crítica ao tipo de classificação relativo à divisão igreja/seita. A sua postura (que é mais teológica) procura desqualificar certos tipos de agências religiosas colocando em relevo o caráter mercantil presente nelas para mostrar não se tratar de religião como acreditavam alguns autores.
} 
religião ${ }^{21}$, aperfeiçoando-se e tornando-se mais apto para cumprir o papel que antes era desempenhado por ela.

[...] até as noções essenciais da lógica científica são de origem religiosa. Certamente, a ciência, para utilizá-las, submete-as a nova elaboração; purifica-as de todo tipo de elementos oportunistas; de maneira geral, ela emprega em todos os seus procedimentos um espírito crítico ignorado pela religião; cerca de precauções para 'evitar a precipitação e a prevenção', para manter à distância as paixões, os preconceitos, e todas as influências subjetivas. Mas esses aperfeiçoamentos metodológicos não bastam para diferenciála da religião. Uma e outra, sob esse aspecto, perseguem o mesmo objetivo; o pensamento científico é apenas uma forma mais perfeita do pensamento religioso. Parece, pois, natural que o segundo se apague progressivamente diante do primeiro à medida que este se torna mais apto para cumprir a tarefa. (DURKHEIM, 1989, p. 507. aspas do autor e destaques_nossos).

Apesar da possível afinidade existente nas relações entre religião e ciência, em alguns setores da vida social a aproximação entre os dois campos é questionada ou impensada. Da mesma forma, na maior parte das vezes, o setor médico - a despeito da tentativa de alguns psiquiatras os colocarem em diálogo, como é o caso que será estudado nesta pesquisa - não vê positivamente a ligação simbólica entre o modelo médico e o modelo religioso; ou seja, não vislumbra a possibilidade de estabelecer pontes entre a racionalidade científica e o universo mágico-religioso. A ideia da medicina como sacerdócio (e a sua característica sacra), neste caso, parece realizar-se apenas em termos de poder e autoridade, e não no que diz respeito a um estreitamento de relações entre religiosos e médicos.

Razão pela qual se constatam muitas controvérsias na relação religião/saúde. Na perspectiva de alguns médicos que consideram importante compreender de que forma a variável religiosa aparece na vida dos pacientes, é considerável ainda o número de especialistas da área médica que não vê fundamentos em tal associação. Considera-se que isso aconteça mais por preconceito do que por embasamento no conhecimento científico (LOTUFO-NETO, 1997, p. 80). Essa resistência, do ponto de vista daqueles que a rechaçam, tem feito

\footnotetext{
21 Essa perspectiva não é aceita por Bourdieu que, assim como Durkheim, acreditava na origem social da religião, mas que diferentemente deste não acreditava na origem religiosa da ciência. Entretanto, convém abrir o leque de interpretações de se pensar a relação entre ciência e religião mesmo que isso implique fazer concessões no sentido de colocar lado a lado interpretações distintas.
} 
com que os médicos ignorem descobertas empíricas importantes ${ }^{22}$, de forma que sejam desconsideradas no planejamento dos programas de saúde (IBIDEM).

Laplantine (2004, p. 214), ao discorrer sobre as possíveis relações entre medicina e religião, observa dois casos distintos: de um lado, situações terapêuticas em que o saber médico e o saber religioso estão estreitamente vinculados, de outro lado, uma situação oposta em que os dois saberes encontram-se dissociados. Neste último caso, segundo o autor, "a eventual dimensão religiosa (da medicina)", ainda que residual ou sob um novo formato, não é notada pela sociedade, seja pelos que recebem a cura, seja pelos que realizam a cura, estes se valendo do argumento de que "são apenas praticantes de uma ciência neutra e objetiva, e nada mais". Ou seja, dependendo de quem observa e de como é observado, nem sempre os aspectos religiosos presentes na medicina serão vislumbrados.

Na revisão da literatura médico-psiquiátrica feita por alguns autores concluiuse que a psiquiatria não dá a devida atenção aos aspectos religiosos. Os resultados da investigação sobre com que frequência a religião está presente enquanto variável nos trabalhos científicos publicados entre 1978 e $1982^{23}$ no American Journal of Psychiatry, no Canadian Journal of Psychiatry e nos Archives of General Psychiatry indicaram o seguinte: de 2.348 artigos quantitativos, apenas cinquenta e nove (3\%) incluíam uma variável religiosa (LARSON et al. (1986) apud LOTUFO-NETO, 1997, p. 188). Uma mesma pesquisa, abrangendo o período de 1991 a 1995, apontou uma queda de 1,8\%. A despeito disso, os estudiosos que vêm se debruçando sobre essas pesquisas alertam para o fato de que esse desprezo pela religião não tem fundamento, já que estudos recentes não veem associação entre psicopatologia e religiosidade; pelo contrário, a relação é entre saúde mental e religiosidade (IBIDEM, p. 87). Não qualquer religiosidade, mas o que se considera uma "religiosidade saudável". Como se verá ao longo deste trabalho, alguns psiquiatras e religiosos compartilham dessa concepção.

\footnotetext{
${ }^{22}$ Em sua tese de livre-docência, Lotufo-Neto (1997, p. 129) faz um apanhado desses achados empíricos e conclui que aqueles que verificaram uma relação positiva entre religião e saúde mental o fizeram medindo saúde mental por meio de eventos da vida real: "saúde física, mortalidade, suicídio, uso de drogas, abuso de álcool, delinqüência e divórcio". Segundo o autor, normalmente, os artigos que costumam associar religião com psicopatologia se valem de "medidas intrapsíquicas", ao passo que os artigos que relacionam religião a saúde mental usam "medidas comportamentais".

${ }^{23}$ Os autores não esclarecem o porquê da escolha desse período.
} 


\title{
1.2 APARATO TEÓRICO METODOLÓGICO: A TEORIA SOCIOLÓGICA DE PIERRE BOURDIEU ${ }^{24}$
}

\begin{abstract}
Miséria do homem sem Deus e sem destino de eleição, que o sociólogo apenas revela, traz à luz do dia, e pelo qual é responsabilizado, como todos os profetas da desgraça. Mas pode-se matar o mensageiro, o que ele anuncia fica dito, e entendido. (Coisas ditas, Bourdieu).
\end{abstract}

\subsubsection{Construção conceitual à luz dos clássicos}

A orientação teórico-metodológica deste trabalho baseia-se na teoria de campo proposta por Pierre Bourdieu que trata do funcionamento interno de diferentes campos sociais e as relações de poder que se travam entre eles. Através dessa noção será possível verificar, de um lado, qual a legitimidade dos agentes religiosos para atuarem dentro de um campo estranho ao seu (no caso, o campo psiquiátrico); de outro lado, verificar se os psiquiatras não estariam colocando em risco a legitimidade do seu campo ao se posicionarem com deferência em relação aos aspectos religiosos presentes na vida dos pacientes.

Entretanto, antes de entrar propriamente na discussão do conceito de campo para Bourdieu, é conveniente entender com quais autores ele dialoga recorrentemente ao longo de sua obra, já que se manterá uma interação constante com os seus conceitos. Existe uma gama de autores com os quais Bourdieu estabelece uma comunicação (seja sob a forma de adesão a conceitos, seja no sentido de reelaboração destes). Pesam sobremaneira os clássicos da sociologia - é possível encontrar no autor as três linhas de pensamento fundadoras: marxista, weberiana e durkheimiana.

\footnotetext{
${ }^{24}$ Para a elaboração deste texto, no qual são apresentados alguns aspectos do pensamento de Bourdieu, além das leituras da obra do referido autor, foi de fundamental importância a participação em Minicurso proferido pelo Prof. François Bonvin (pesquisador do grupo da EHESS), realizado durante $036^{\circ}$ Encontro Nacional de Estudos Rurais e Urbanos do CERU (no período de 18 a 20/05/09) bem como sugestões do mesmo professor quanto ao encaminhamento da tese aliado a aspectos da teoria de Bourdieu.
} 
Apesar de não se considerar filiado a nenhuma perspectiva das citadas anteriormente, é fundamental, para compreender Bourdieu, estar atento à sua vinculação com Marx, Durkheim e Weber. Ele lança mão da epistemologia desses autores, utilizando-os como ferramentas para fabricar as suas próprias, para construir seus próprios conceitos. Nesse sentido, afirma: "Se eu tivesse que caracterizar meu trabalho em duas palavras, ou seja, como se faz muito hoje em dia, se tivesse que lhe aplicar um rótulo, eu falaria de constructivist structuralism ou de structuralist constructivism,25 (BOURDIEU, 2004b, p. 149, destaque do autor).

Ou seja, ele não toma para si uma doutrina tout court e a reproduz. Por exemplo, fundamenta-se em Marx e Durkheim ${ }^{26}$ quanto à questão da historicidade do espírito humano e baseia-se em Weber quanto à questão do Ethos de classe expressão bem antiga já utilizada no pensamento filosófico para tratar das condutas humanas - denominada de habitus (informação verbal) ${ }^{27}$.

Além dos autores supracitados, para elaborar os seus conceitos mais preciosos, Bourdieu dialoga ao longo de sua obra com autores como Merleau-Ponty e Sartre ${ }^{28}$. Trava um debate profícuo com o estruturalismo ${ }^{29}$, mas não o rechaça de todo: "O capital teórico do estruturalismo não podia ser empregado tal qual e precisava ser 'revisitado'" (PINTO, 2000, p. 47, aspas do autor). Ele faz críticas à noção de regras (do estruturalismo) e fala em estratégias, as quais abririam possibilidades de mobilização dos agentes. Na fenomenologia (influenciado por

${ }^{25}$ Construtivista-estruturalista, em contraposição ao estruturalismo de Althusser, de Lévi-Strauss e para não ser confundido com os construtivistas, com os etnometodólogos (informação fornecida por François Bonvin, em minicurso mencionado anteriormente).

${ }^{26}$ A questão da historicidade do espírito, Durkheim por sua vez tomou de Marx, para quem (em contraposição às categorias transcendentais construídas por Kant e ao idealismo proposto por Hegel) as categorias provêm da prática.

${ }_{27}$ Informações obtidas com François Bonvin.

${ }^{28}$ No que diz respeito ao existencialismo de Sartre, a relação é mais contestatória do que de aproximação: "Depois de haver partilhado um momento da visão do mundo do 'filósofo normalista francês dos anos 50', levada por Sartre a sua culminância [...] posso dizer que me construí, ao sair do universo escolar, e para daí sair, contra tudo aquilo que para mim representava o empreendimento sartriano. O que eu menos apreciava em Sartre era [...] em particular, sua contribuição sem equivalente para a mitologia do intelectual livre, que lhe garante o reconhecimento eterno de todos os intelectuais. [...] aqueles (eu inclusive) desejosos de resistir ao 'existencialismo' em sua forma mundana ou escolar podiam recorrer a um conjunto de correntes dominadas: [...] uma epistemologia e uma história das ciências representadas por autores como Gastón Bachelard, Georges Canguilhem e Alexandre Koyré" (BOURDIEU, 2005, p. 45, 56).

${ }^{29}$ Influenciado pela figura de Claude Lévi-Strauss, um nome importante do estruturalismo, cujo modelo desfrutava de grande prestígio na França, conquanto Bourdieu não se considerasse estruturalista: "Minha única participação no debate estruturalista é um texto de postura antiestruturalista bastante nítida a respeito do campo intelectual [...] e, portanto, é preciso estar malintencionado, ou apenas mal informado, para situar-me entre os 'estruturalistas'" (IBIDEM, p. 103 e 104 , aspas do autor). 
Husserl e Maurice Merleau-Ponty), o privilégio é dado à experiência prática ${ }^{30}$. No final das contas, tenta conjuminar duas perspectivas antitéticas como a ação prática presente na fenomenologia, de um lado, e as relações de poder ${ }^{31}$ e dominação de outro lado. Sem esquecer obviamente de quão importante foi a influência de autores como Bachelard e Canguilhem (representantes da tradição da história das ciências). Segundo Pinto (2000, p. 12), a obra de Bourdieu é muito útil, pois ela consegue realizar uma reunificação de tradições intelectuais "até então distintas", como, por exemplo, "a tradição da epistemologia histórica das ciências à francesa e a tradição da sociologia (marxista e weberiana) das relações de força entre grupos com interesses contraditórios". Ou seja, o autor consegue movimentar-se entre tradições diversas, possibilitando dessa forma um diálogo enriquecedor entre elas.

Todo esse legado intelectual contribuiu para que Bourdieu conseguisse pensar o mundo social de uma forma mais abrangente e dinâmica. $O$ "espaço de possíveis"32 é posto em pauta levando em consideração questões como a historicização do espírito humano, as relações de poder existentes, a importância da experiência prática ${ }^{33}$ e das estratégias dos agentes, questões que foram emprestadas de outros pensadores. Com isso, o objetivo de Bourdieu (1999, p. 27) era o de ocupar um "lugar geométrico" em relação ao "espaço de possíveis" teóricos de que dispunha que possibilitasse contemplar a contribuição das diferentes

\footnotetext{
${ }^{30}$ Segundo Pinto (2000, p. 43 e 45), Merleau-Ponty foi um dos filósofos que mais procurou evidenciar a especificidade da experiência prática: "A experiência pressupõe algo como um a priori, noção de que Merleau-Ponty se apropria procurando, porém, dissociá-la do sujeito transcendental que geralmente serve para fundá-la".

${ }_{31}$ A intenção do autor ao introduzir na sociologia noções de espaço social e de campo do poder esta criticada por muitos intelectuais - é de estabelecer uma ruptura com a tendência de pensar o mundo social de maneira substancialista. Além disso, a noção de campo de poder foi necessária "para dar conta de efeitos estruturais que não podiam ser compreendidos de outro modo" (BOURDIEU, 1996b, p. 51). Lembrando que, segundo o autor, o campo do poder não deve ser confundido com o campo político, pois aquele não é um campo como os outros: "Ele é o espaço de relações de força entre os diferentes tipos de capital ou, mais precisamente, entre os agentes suficientemente providos de um dos diferentes tipos de capital para poderem dominar o campo correspondente e cujas lutas intensificam sempre que o valor relativo dos diferentes tipos de capital é posto em questão" (IBIDEM, p. 52).

${ }^{32}$ O espaço de possíveis para Bourdieu (1996b, p. 54) seria o equivalente ao contexto social. Ele está associado a um campo relativamente autônomo, já que uma das funções deste é dar conta da determinação específica exercida pelo espaço de possíveis: "É o que faz com que os produtores de uma época sejam ao mesmo tempo situados, datados, e relativamente autônomos em relação às determinações diretas do ambiente econômico e social [...]. Esse espaço de possíveis que transcende os agentes singulares funciona como uma espécie de sistema comum de coordenadas que faz com que, mesmo que não se refiram uns aos outros, os criadores contemporâneos estejam obviamente situados uns em relação aos outros". Por exemplo, em As regras da arte (1996a), ele fala do espaço de possíveis para Flaubert.

${ }^{33}$ É possível reconhecer na teoria da prática a noção de ser-no-mundo, a qual é própria dos filósofos de inspiração fenomenológica e existencialista (PINTO, 2000, p. 48).
} 
perspectivas. Segundo o autor, para escapar do que ele denomina um ou outro "círculo mágico" e não se arriscar ser apanhado por outro, é necessário encontrar o referido "lugar geométrico" que comporta as diferentes perspectivas; ou seja, é preciso posicionar-se "no ponto de onde se possa perceber ao mesmo tempo aquilo que pode e aquilo que não pode ser percebido de cada um dos pontos de vista". A ideia, que parece bem ambiciosa, é colocar lado a lado (fazendo obviamente as devidas considerações) construções teóricas até então distanciadas, com o intuito de melhor apreender o mundo social.

A concepção mais marcante no autor é da ação ligada à disposição profunda formada pelo fato de que o sujeito foi socializado e vive em circunstâncias bem precisas. O indivíduo é o produto do encontro entre estruturas - determinações exteriores do mundo que preexistem a ele - e sua própria subjetividade. Nesse sentido, Bourdieu foi muito influenciado por Marx para quem - em oposição à ideia de categorias transcendentais teorizada pelo Kantismo - o espírito humano com suas categorias de percepção seria uma formação histórica, proveniente da prática. O que Marx havia anunciado é a necessidade de historicizar ${ }^{34}$ o mundo social, construir a gênese das coisas.

Num outro formato, Durkheim retoma essa ideia: as estruturas objetivas do mundo e as categorias mentais, uma é a interiorização da outra. Ou seja, não é possível pensar os produtos mentais independentemente das estruturas objetivas exteriores $^{35}$. Bourdieu retoma essa concepção e elabora a sua perspectiva de que existem estruturas objetivas que se interiorizam, que formam a subjetividade. $O$ autor acrescenta ainda que a interiorização das estruturas objetivas (exteriores) é algo que não é consciente, vem de maneira prática; ou seja, o sujeito não tem consciência de ser dela portador, é na ação prática que isso vem a existir. $E$ é aí que reside toda a concepção de habitus ${ }^{36}$. Seguindo o caminho trilhado por autores

\footnotetext{
${ }^{34}$ A sociologia proposta por Bourdieu vê na historicização "um meio de lutar contra os efeitos da naturalização" (PINTO, 2000, p. 10). Bachelard tem influência nodal nessa direção na obra de Bourdieu, visto que para aquele autor os objetos de ciência possuem um caráter essencialmente histórico: "contrariamente à filosofia universitária, Bachelard sugeria tratar os conceitos como instrumentos históricos, e não como essências intemporais" (IBIDEM, p. 20).

${ }^{35}$ Essa problematização é proveniente da teoria marxista, mas foi bem formalizada por Mauss e Durkheim. O que Bourdieu faz é retomá-la e dar a ela um novo toque por meio da praxiologia.

${ }^{36}$ Concepção emprestada de Panofsky: "[...] Opor a individualidade à coletividade para resguardar os direitos da individualidade criadora [...] é privar-se, para utilizar a linguagem de Erwin Panofsky, do habitus que faz o criador participar de sua coletividade, de sua época [...]" (BOURDIEU, 1999, p. 342, destaque nosso).
} 
como os supracitados, Bourdieu (1983b, p. 59) esforça-se em fazer notar que "o que, por todos os cantos, se chama de social é história".

A história está inscrita nas coisas, isto é, nas instituições (as máquinas, os instrumentos, o direito, as teorias científicas, etc.), e também no corpo. Todo o meu esforço é no sentido de descobrir a história nos lugares onde ela melhor se esconde, nos cérebros e nas dobras do corpo. O inconsciente é história. E é assim, por exemplo, nas categorias de pensamento e de percepção que espontaneamente aplicamos ao mundo social.

Nesse sentido, é possível perceber a importância que a questão da historicização do espírito humano tem na teoria bourdieusiana: todos os conceitos com os quais se lida têm uma explicação na razão histórica e, por conta disso, não é possível abdicar de historicizar a maneira de pensar o mundo social. Nessa direção, vê-se Bourdieu (2001, p. 91) tratar em Meditações Pascalianas do que ele chama de três formas do erro escolástico que são centrais para a sociologia: o primeiro erro seria o cientificismo - o erro do cientificismo que desrespeita a experiência do agente, que possui a tendência de intelectualizar os sujeitos; o segundo erro seria o moralismo ético - ideias universalistas que querem dar conta de uma quantidade de respostas uniformes para o mundo que não é possível, tais ideias desconsideram a dinâmica do todo social; e, por fim, o terceiro erro, que seria o esteticismo - o silenciamento "a respeito das condições sociais de possibilidade" do juízo de gosto.

Um autor que muito o influenciou na elaboração da noção de campo foi Max Weber (BOURDIEU, 2007, p. 66). Bourdieu, ao discorrer sobre “campo", apoia-se inicialmente na teoria weberiana das esferas de valor, mas faz uma reinterpretação desta, visto que algumas definições propostas por aquele autor são, segundo seu ponto de vista, definições históricas inconscientemente universalizadas, sendo adequadas apenas para "um estágio histórico do campo" (IDEM, 2004b, p. 120) ${ }^{37}$.

\footnotetext{
${ }^{37}$ Apesar de Weber ser um autor constantemente citado, Bourdieu questiona alguns aspectos da sua teoria (assim como questiona Marx, Durkheim, Lévi-Strauss, etc.). É o caso, por exemplo, do "carisma" atribuído ao profeta. Segundo o autor, Weber atribui uma qualidade individual a algo que na verdade provém do coletivo. A crítica diz respeito ao fato de o carisma ser considerado uma "propriedade associada à natureza de um indivíduo singular" (BOURDIEU, 1999, p. 74). Na verdade, trata-se de "um indivíduo socialmente predisposto a sentir e a expressar com uma força e uma coerência particulares certas disposições éticas ou políticas já presentes, em estado implícito, em todos os membros da classe ou do grupo de seus destinatários" (IBIDEM). Seria, pois, a comunidade que conferiria ao profeta seu dom e não que esse dom imanasse dele. Outro questionamento feito por Bourdieu à teoria de Weber, e ao qual já foi feita referência em outro momento, diz respeito ao uso da noção de teodiceia.
} 
Assim, ao referir-se à expressão "caso particular do possível" empregada por Bachelard, Bourdieu procura ilustrar a maneira que considera cientificamente viável de entender o mundo social. O autor procura evidenciar que a apreensão da "lógica mais profunda do mundo social" (BOURDIEU, 1996b, p. 15) só é possível mediante a submersão "na particularidade de uma realidade empírica" (IBIDEM), para confeccioná-la, entretanto, como "caso particular do possível”; ou seja, "como uma figura em um universo de configurações possíveis" (IBIDEM).

Ao relatar sua relação com Max Weber, Bourdieu (2004b, p. 65) afirma que "é possível pensar com um pensador contra esse pensador". Nesse sentido, ele admite ter construído a noção de campo "contra Weber e ao mesmo tempo com Weber" (IBIDEM). Essa forma de fazer sociologia possibilita fugir a uma lógica classificatória do "a favor ou contra" comumente utilizada para pensar-se "a relação com as idéias do passado" (IBIDEM). Posto isso, o autor lembra que se autodenominar de tal ou qual corrente de pensamento "é uma alternativa religiosa e de modo algum científica" (IBIDEM, p. 66). Na verdade, essa forma classificatória a partir da qual funciona o pensamento acadêmico é um empecilho ao progresso da pesquisa, pois "muitas vezes embaraça a invenção intelectual” (IBIDEM, p. 41). Quando ele recorre a outros autores é, portanto, no sentido de tomá-los como "companheiros", como "alguém a quem se pode pedir a mão nas situações difíceis" (IBIDEM).

Evidentemente, como afirma Bourdieu (2004b, p. 43), "não se pergunta qualquer coisa a qualquer um... É o papel da cultura apontar os autores em que se tem possibilidade de encontrar ajuda". Se ele reporta-se a Marx, Durkheim e Weber, é seguramente pelo fato de esses autores serem grandes referenciais na sociologia e por terem colocado questões, sem dúvida alguma, muito relevantes. Para Bourdieu, fazer ciência é um jogo que para ser levado a sério é necessário "recusar as definições anteriores do jogo e do que está em jogo; significa, por exemplo, operar uma mudança absolutamente radical em relação a Max Weber, afirmando que o campo religioso é um espaço no qual agentes, que é preciso definir (padre, profeta, feiticeiro, etc), lutam pela imposição da definição legítima não só do religioso, mas também das diferentes maneiras de desempenhar o papel religioso" (BOURDIEU, 2004b, p. 120). 
Dito isso, é importante destacar o quanto Bourdieu (2007, p. 63) traz uma reflexão em todos os seus escritos sobre a antiga oposição Marx, Weber e Durkheim. Para o autor, tal oposição traz uma paralisia ao pensamento, é algo que não contribui, mas sim atrapalha a construção do conhecimento social. Na busca forçada por uma originalidade - que normalmente tem como impulso "a ignorância e a fidelidade religiosa a este ou àquele autor canônico" - acaba-se, na verdade, sendo injusto para com a tradição teórica, na medida em que se impede de "afirmar, ao mesmo tempo, a continuidade e a ruptura, a conservação e a superação [...] ir além dos antecessores, ultrapassados assim por uma utilização nova dos instrumentos para cuja produção eles contribuíram"38 (IBIDEM). Ou seja, a adesão às teorias, pura e simplesmente, sem o seu manuseio crítico - este no sentido de perceber não somente as suas contribuições, mas também as suas insuficiências é apontada como algo não frutífero ao pensamento.

Resumindo, Bourdieu (2004b, p. 26) diz ser avesso a rotulações. Afirma que, se gostasse de jogar esse jogo frequentemente colocado em prática no campo intelectual, diria então que o que tenta elaborar é um "estruturalismo genético". Dessa feita, buscaria aliar a análise de estruturas objetivas à análise da gênese das estruturas mentais (a qual está relacionada aos indivíduos biológicos) e à análise da gênese das próprias estruturas sociais.

\subsubsection{Habitus, capital e campo}

Na teoria bourdieusiana, os conceitos de "habitus", "capital" e "campo" estão interligados, há uma solidariedade entre eles. Por isso, em toda ocasião em que são utilizadas essas definições é necessário estar atento à conexão que há entre elas. Falar de campo é, obrigatoriamente, tratar de capital e de habitus. Isso porque a

${ }^{38}$ O próprio Weber (1993, p. 29 , destaque e aspas do autor), ao discorrer, em "A ciência como vocação", sobre o fato de o trabalho científico estar ligado ao curso do progresso, alerta sobre o "destino" - o de ser ultrapassado (ao contrário do que acontece com o domínio da arte) - a que deve resignar-se quem se dedica à ciência. Assim, afirma o autor: "Qual é, em verdade, o destino ou, melhor, a significação, em sentido muito especial, de que está revestido todo trabalho científico, tal como, aliás, todos os outros elementos da civilização sujeitos à mesma lei? É o de que toda obra científica 'acabada' não tem outro sentido senão o de fazer surgirem novas 'indagações': ela pede, portanto, que seja 'ultrapassada' e envelheça". 
definição de uma identidade social é referente à determinada forma de capital e a determinado tipo de habitus num campo específico onde eles funcionam para agir socialmente ${ }^{39}$.

\subsubsection{Habitus}

O habitus é a forma de cada agente social tornar compatíveis sentimentos externos e internos, é sempre a relação da probabilidade objetiva e as expectativas ${ }^{40}$. Trata-se de um conjunto de disposições que vão caracterizar uma classe de posição ${ }^{41}$. Ao investigá-lo, mediante regularidades (preferencialmente

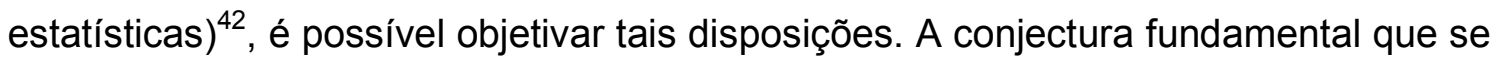
faz presente na obra bourdieusiana é a de que todo tipo de existência possui regularidades, as quais são interiorizadas, incorporadas como disposição. E seria isso que constituiria o habitus.

Para entender o trabalho científico de Bourdieu, a sua construção teórica, para compreender como ele chegou até a questão da disposição, da distinção ${ }^{43}$, do

\footnotetext{
${ }^{39}$ Obviamente, não se tem um capital que valha em todo lugar.

${ }^{40}$ Importante para se entender o conceito de habitus em Bourdieu é pensar a ideia de um opus operatum (coisa feita), como pensa Lévi-Strauss em contraposição a um modus operandi (jeito de fazer, ação): "A tradição objetivista concebe o mundo social como um universo de regularidades objetivas independentes dos agentes e construídas a partir do ponto de vista do observador imparcial que está fora da ação, que sobrevoa o mundo observado. O etnólogo é alguém que reconstitui uma espécie de partição não escrita, que organiza as ações de agentes que crêem improvisar, cada qual sua melodia, enquanto na realidade [...] eles agem conforme um sistema de regras transcendentes" (BOURDIEU, 1983b, p. 70).

41 "A ação tem como princípio um sistema de disposições, que chamo de habitus, que é o produto de toda a experiência biográfica (o que, como não existem duas histórias individuais iguais, faz com que não existam dois habitus idênticos, embora haja classes de experiências e, portanto, classes de habitus - os habitus de classes)" (IBIDEM, p. 60).

${ }^{42}$ Não é possível conhecer as disposições por intermédio de uma autorreflexão. Esse conhecimento só pode realizar-se mediante a objetivação, trazendo à baila as regularidades das condutas. Dessa forma o autor procede na obra $A$ distinção (2008), na qual são realizadas estatísticas bem construídas sobre determinados usos e práticas, o que propicia objetivar as disposições por camada social. Segundo François Bonvin, até então não havia uma sociologia argumentada no recurso da construção estatística que permitisse detectar a objetivação. Bourdieu inova nesse sentido (informação verbal).

${ }^{43}$ Bourdieu utiliza a distinção num momento histórico em que se discutia a aplicabilidade do conceito de classe social. Na sua perspectiva, as classes sociais não existem, ao contrário, o que existe é um espaço social, um espaço de diferenças: "A teoria marxista comete um erro [...] ela dá um 'salto mortal' da existência na teoria à existência na prática [...]. Não se passa da classe-no-papel à classe 'real', se é que ela existiu alguma vez 'realmente', é apenas a classe realizada, isto é, mobilizada, resultado da luta de classificações como luta propriamente simbólica (e política) para impor uma visão
} 
habitus é necessário remontar aos seus trabalhos iniciais ${ }^{44}$ voltados para a questão do mundo rural ${ }^{45}$, que tem, por exemplo, nas pesquisas sobre a Argélia o destaque da obra Travail et travailleurs en Algerie (Trabalho e trabalhadores na Argélia) ${ }^{46}$. É aí onde tudo começa ${ }^{47}$. Nessa obra irá discorrer sobre a crise no mundo camponês ${ }^{48}$. Ele pesquisará a sociedade Cabila e os efeitos das transformações econômicas e políticas exercidas sobre ela. Mediante tais pesquisas - inicialmente as realizadas na Argélia e no Béarn -, Bourdieu notava um desajuste entre o estado das estruturas

do mundo social" (BOURDIEU, 1996b, p. 25-26, aspas e destaque do autor). Ele tentou mostrar que é a maneira que conta, que distingue. Na obra $A$ distinção (2008) faz uma vasta pesquisa sobre os processos de diferenciação social: "O que comumente chamamos de distinção, uma certa qualidade, mais frequentemente considerada como inata, de porte de maneiras, é de fato diferença, separação, traço distintivo, resumindo, propriedade relacional que só existe em relação a outras propriedades" (IDEM, 1996b, p. 18, destaques do autor). O autor pretendia produzir uma "teoria sociológica das categorias que organizam a percepção do mundo social e que por isso contribuem para produzi-lo" (IDEM, 2004a, p. 11).

${ }^{44}$ Necessário estar atento à genealogia dos conceitos presentes na obra de Bourdieu, por intermédio das suas primeiras pesquisas. O entendimento dos conceitos, do pensamento, do método de Bourdieu passa, necessariamente, pelo estudo das suas pesquisas iniciais. Assim, far-se-á jus à opinião do autor, que credita a Georges Canguilhem uma contribuição decisiva "para a análise rigorosa dos conceitos científicos e dos obstáculos históricos à sua emergência" (IDEM, 2005, p. 58).

${ }^{45}$ Bourdieu irá tratar da crise no mundo camponês em obras como Le déracinement, La crise de l'agriculture traditionelle em Algérie, Paris: Minuit, 1964; Algérie 60, structures économiques et structures temporelles, Paris: Minuit, 1977; Célibat et condition paysanne. Études Rurales, n.5-6, p. 32-136, avr-sept. 1962; Travail et Travailleurs en Algérie, Paris, La Haye, Mouton, 1963. Nessas obras, o autor trata de questões como a crise da agricultura tradicional na Argélia, o encontro da sociedade camponesa argelina tradicional com o espírito do capitalismo. Ele mostra que a crise do campesinato não se relaciona simplesmente com o capitalismo agrário, mas também com outros mecanismos sutis relacionados "com a própria reprodução e, inclusive, com a reprodução biológica dos indivíduos" (BOURDIEU, 2004a, p. 9).

${ }^{46}$ Inicialmente intitulada Sociologie de l'Algérie. Paris: PUF, 1958 (Coll. Que sais-je?, 802), primeiro livro de Bourdieu, publicado em 1958.

${ }^{47}$ Segundo Bonvin, na Argélia, Bourdieu realiza um conjunto de pesquisas, para as quais ele precisará de uma noção teórica para relacionar as suas observações. O que ele irá observar nas referidas pesquisas são regularidades e irregularidades, observa um grupo de indivíduos que permanece com a sua disposição no mundo mais ou menos estável ou o contrário. Assim, formula a ideia de ajuste do agente, ajuste das disposições ao contexto, ao social exterior: "Em situações de crise ou de rápida mudança, certos agentes, freqüentemente os que eram justamente os mais bem adaptados ao estado anterior do jogo, têm dificuldade de se ajustar à nova ordem estabelecida [...]. É o caso desses herdeiros de 'família importante', por mim observados na região do Béarn, nos anos sessenta, que se condenavam ao celibato e a uma espécie de morte social [...]" (BOURDIEU, 2001, p. 197, aspas do autor).

${ }^{48}$ Essa temática do mundo rural será tratada tanto em relação à Argélia quanto em relação à sua terra natal, o Béarn. Neste realizou uma pesquisa (que resultou na confecção de três artigos, os quais foram retomados em Le bal des célibataires: Crise de la société paysanne en Béarn) a respeito do celibato dos filhos mais velhos. Há um desajuste das disposições e dos habitus corporais que faz com que esses rapazes não sejam escolhidos para se casar: "Ao unificar-se em escala nacional [...], o mercado matrimonial havia condenado a uma brusca e brutal desvalorização os que estavam atados ao mercado protegido das antigas trocas matrimoniais controladas pelas famílias, os primogênitos de família importante, bons partidos de repente convertidos em camponeses ruralizados, hucous (homens do mato) repulsivos e selvagens, excluídos de uma vez por todas do direito à reprodução" (IDEM, 2005, p. 92, destaque do autor). 
objetivas e as estruturas incorporadas sob a forma do habitus ${ }^{49}$ dos agentes. Ele faz suas reflexões tomando as regularidades das condutas, das práticas, procurando relacioná-las com as estruturas objetivas do mundo no qual vivem essas classes de indivíduos ${ }^{50}$.

A questão é captar, de um lado, como a exterioridade do mundo social que preexiste ao sujeito torna-se interiorizada sob a forma de disposições e, de outro lado, como essas disposições (a subjetividade interiorizada) vão se conservando. Destarte, Bourdieu procura fazer uma sociologia relacional ao pensar o corpo numa relação que muda com a mudança do espaço. $E$ isso seria o habitus ${ }^{51}$ : uma estrutura estruturada pelo tipo de vida, pela experiência, pela história e funcionando, por sua vez, como estrutura estruturante das percepções ${ }^{52}$. O habitus ${ }^{53}$, essa estrutura objetiva determinada pelo exterior, apreende tanto os condicionamentos sociais quanto a liberdade no comportamento dos atores. Ou seja, ele irá estruturar as percepções e interpretações do mundo.

\footnotetext{
${ }^{49}$ Segundo Pinto, foi graças às pesquisas realizadas na Argélia que Bourdieu pôde "valer-se de um capital teórico em grande parte constituído pela antropologia estrutural, e sabemos o quanto a sua teoria do habitus deve às suas experiências de campo e ao trabalho teórico daí decorrente" (PINTO, 2000, p. 38).

${ }^{50}$ A noção de habitus, tirada de seu contexto inicial, adquiria alcance universal. Ela tornava-se "uma maneira global de examinar os dados mais diversos submetendo-os à questão recorrente de saber como e em que limites se verifica o ajustamento entre as estruturas objetivas e as estruturas interiorizadas, incorporadas pelos agentes sob a forma de um senso prático" (IBIDEM, p. 39).

${ }^{51} \mathrm{O}$ habitus enquanto "estrutura estruturada predisposta a funcionar como estrutura estruturante" (BOURDIEU, 1972, p. 175) diz respeito não apenas à interiorização das normas, ele concerne também aos sistemas de classificações (logicamente) preexistentes. Há um sistema de classificação, logicamente, anterior à ação. Os habitus, além de serem princípios geradores de práticas distintas e distintivas, eles "são também esquemas classificatórios, princípios de classificação, princípios de visão e de divisão e gostos diferentes" (IDEM, 1996b, p. 22), isso por intermédio do que o autor chama de "categorias sociais de percepção" como, por exemplo: bom/mau, bem/mal, distinto/vulgar (IBIDEM). Especificamente nesse tipo de análise, Bourdieu faz uso das reflexões de Durkheim e Mauss sobre as classificações primitivas (Vide DURKHEIM, E. e MAUSS, M. De quelques formes primitives de classification. In: MAUSS. Marcel. Oeuvres. Paris, P.U.F., 1969. t. II, p. 13-89). Segundo Bourdieu (1996b, p. 115, aspas do autor), "os agentes sociais constroem o mundo social através de estruturas cognitivas ('formas simbólicas', como diz Cassirer; formas de classificação, como diz Durkheim; princípios de visão e de divisão; várias maneiras de dizer a mesma coisa em tradições teóricas mais ou menos distanciadas)".

52 Nas observações realizadas na Argélia, o autor irá atentar para a questão do ajustamento/desajustamento. No primeiro caso há uma estruturação espacial e temporal, uma vida tradicional com o espaço organizado, um calendário organizado, todas as regularidades sociais, no outro caso a sociedade é alterada (as vilas transformam-se em acampamentos, situação esta em que os sujeitos encontram-se perdidos, sem estrutura ocupacional, espacial, temporal).

${ }^{53}$ Segundo François Bonvin (informação verbal), também foi designado por Weber pela noção de Ethos de classe, termo bem antigo no pensamento das condutas humanas. Bourdieu interessa-se, na construção do habitus, pelas regularidades. Em Weber, seria a ideia protestante, a previsão calculada em vez da previsão dia a dia. (informações obtidas em minicurso já mencionado).
} 
O corpo está no mundo social, mas o mundo social está no corpo (sob forma de hexis e de eidos). [...] A relação dóxica com o mundo natal é uma relação de pertencimento e de posse na qual o corpo possuído pela história se apropria de maneira imediata das coisas habitadas pela mesma história. É somente quando a herança se apropriou do herdeiro que o herdeiro pode se apropriar da herança. (BOURDIEU, 2001, p. 185).

O autor pensa a hexis corporal ${ }^{54}$, o habitus corporal, as disposições do corpo como interiorizadas, porém não conscientes. O habitus é uma estrutura prática da qual o indivíduo não tem consciência ${ }^{55}$, ele opera as condutas, mas não tem consciência disso. Agentes nativos sabem o que estão fazendo sem o saber, ou seja, a prática é cega com relação aos mecanismos que fazem com que se a execute $^{56}$.

Panofsky lembra que quando alguém tira seu chapéu para cumprimentar, está reproduzindo, sem o saber, o gesto dos cavaleiros da Idade Média, que tiravam seus capacetes para manifestar suas intenções pacíficas. Ao longo do tempo, fazemos o mesmo. Quando a história feita coisa e a história feita corpo se combinam de uma forma perfeita as regras do jogo e o sentido do jogo, como no caso do jogador de futebol, o ator faz exatamente o que ele tem que fazer, 'a única coisa a fazer', como se diz, sem nem mesmo precisar saber o que faz. Nem autômato nem calculador racional, ele é um pouco como L'Orion Aveugle se dirigeant vers de soleil levant, do quadro de Poussin, tão caro a Claude Simon [...]. (BOURDIEU, 1983b, p. 60, aspas e destaque do autor).

Os diferentes grupos realizam experiências distintas do mundo. As classes de indivíduos estão expostas a determinações diferentes, em função das quais realizam suas experiências. Estas acontecem, então, em diferentes mundos objetivos de constrangimentos ou de possíveis. Essa é a forma que Bourdieu encontra para escapar à ideia de que o comportamento é uma reação direta a um

\footnotetext{
${ }^{54} \mathrm{Em}$ Bourdieu (2007, p. 61) há a retomada da noção aristotélica de hexis, a qual fora convertida pela escolástica em habitus. O autor utiliza o conceito de hexis corporal (que no caso seria o jeito de vestir-se, de andar, de atravessar o espaço, ou seja, todo o estilo corporal): "Uma maneira de manter e conduzir o corpo" (IDEM, 2001, p. 175). Esse habitus corporal, para mudá-lo seria necessário mudar a própria "natureza", porquanto, ele "consiste naquilo que se vive como mais natural, aquilo sobre o que a ação consciente não tem controle" (IDEM, 2002). Normalmente, o indivíduo é marcado por uma hexis corporal que, antes de tudo, é um signum social (IBIDEM).

${ }^{55}$ Segundo François Bonvin (informacão verbal), Bourdieu não usa o termo inconsciente porque poderia haver uma confusão com o conceito da Psicanálise, utiliza o termo não-consciente.

${ }^{56}$ Entretanto, dizer que a prática é cega não é o mesmo que afirmar que o campo é o equivalente a um jogo de forças cegas (o autor nunca pretendeu dar tal conotação), porquanto "num campo existem reais possibilidades de transformação, mas que são muito diferentes conforme a posição ocupada" (PINTO, 2000, p. 10).
} 
estímulo, às condições exteriores ${ }^{57}$. Ele procura escapar à perspectiva, de um lado, de que o agente é somente o portador de uma estrutura e, de outro lado, da concepção de um sujeito indeterminado. Daí, o conceito de interiorização da exterioridade e exteriorização da interioridade, dialética construída pelo autor também com a intenção de objetivar a noção de dom, de inteligência diferencial, mostrando que tudo é resultado de exposição a condições diferentes ${ }^{58}$. Vale lembrar que para o autor relações objetivas são as que não dependem da vontade dos agentes. As relações objetivas a que todos estão expostos serão vivenciadas diferentemente através das disposições de cada um. Nesse sentido, nas palavras de Bourdieu (2001, p. 139 e 140, aspas do autor), "contra o fetichismo platonizante que ronda todo o pensamento escolástico" é necessário "renunciar à mitologia do 'criador' incriado" e no seu lugar procurar admitir que "o verdadeiro 'sujeito' das obras humanas mais bem-sucedidas não é outro senão o campo"; é graças a ele e ao mesmo tempo contra ele que as obras se realizam. Certamente, constata Bourdieu, "a arte nasce do constrangimento", este executado "pela estrutura objetiva das possibilidades e impossibilidades inscritas num campo ou que, para ser mais preciso, surgem da relação entre um habitus e um campo" (IBIDEM). Aqui o autor faz a movimentação teórica entre os conceitos de habitus e campo, procurando evidenciar a sua estreita ligação.

A experiência prática em relação às possibilidades e às impossibilidades para cada sujeito enquanto classe de indivíduos: aí está a constituição de um sistema de disposição sistemático que Bourdieu denomina de habitus. A experiência prática faz com que o agente identifique-se ou não a uma classe. Por intermédio dessa experiência, que é a de identificação ao seu grupo e diferenciação de outro grupo, interioriza-se um senso prático, o qual não é intelectualizado, não demanda reflexão, é incorporado. Trata-se de um habitus que não se apresentará impositivamente, mas mediante uma identificação que ocorrerá tanto por parte do ingressante no campo em relação aos que lá se encontram como o contrário.

Na realidade, em lugar do habitus tácita ou explicitamente exigido, o novo postulante deve trazer para o jogo um habitus praticamente compatível, ou suficientemente próximo, e acima de tudo maleável e

\footnotetext{
${ }^{57}$ É uma contraposição ao estruturalismo de tipo marxista.

${ }^{58}$ Mediante essas noções, o autor questiona pressupostos como a ideologia do dom e a autonomia da obra, no que diz respeito a uma excelência cultural.
} 
suscetível de ser convertido em habitus ajustado, em suma congruente e dócil, ou seja, aberto à possibilidade de uma reestruturação. É a razão pela qual as operações de cooptação prestam atenção aos sinais de competência e ainda mais aos indícios quase imperceptíveis, quase sempre corporais, postura, compostura, maneiras, disposições de ser e sobretudo de vir a ser. [...] (BOURDIEU, 2001, p.120).

O sentido prático enquanto disposição sistemática (Bourdieu construiu essa sistematicidade contra uma suposta liberdade, fantasia do ator) como forma de avaliar o possível ou o impossível para atuar no mundo social. Segundo François Bonvin (informação verbal), o pensamento de Bourdieu leva a acreditar que não há uma reflexividade, o que não é verdade. Ao seguir a linha de pensamento da fenomenologia de Merleau-Ponty, ele contrapõe-se à concepção que percebe o espírito humano como algo feito, como uma estrutura eternal. Ao divergir de tal perspectiva, ele procura, a seu modo, historicizar o espírito humano, com o intuito de fazer notar que existe um agente que é indissociavelmente corpo agindo e inteligência, sensibilidade ${ }^{59}$. Merleau-Ponty (1990, p. 100) faz referência ao jogo. Ele trabalha sobre o sentido do jogo, o qual está relacionado ao fato de não ser necessário ao jogador de futebol pensar para jogar, pois a ciência do jogo dele está no corpo, é incorporada e completamente prática. Obviamente que há de haver um tanto de mobilização de estratégias pensadas conscientemente, reflexivamente, mas o essencial do jogo dele é o corpo que pensa de um jeito prático na instantaneidade. Ou seja, o sentido do jogo é não-consciente. ${ }^{60}$.

O campo de futebol não é para o jogador em ação um 'objeto' [...]. O campo não the é dado, mas se apresenta como o termo imanente às suas intenções práticas; o jogador forma com ele um todo e sente, por exemplo, a direção do 'gol' tão imediatamente quanto a vertical e a horizontal de seu corpo. (MERLEAU-PONTY, 1990 apud PINTO, 2000 , p. 44, aspas do autor).

Bourdieu retoma essa ideia de Merleau-Ponty. Isso foi muito importante para a construção do sentido prático, do que é na ação essa inteligência que vem da história do indivíduo, da sua experiência que é incorporada. Para Bourdieu, não se trata apenas de categorias de pensamento. Sob a forma de habitus, é a

${ }^{59}$ Autores como Canguilhem, Bachelard são a genealogia do tipo de ciência social empreendida por Bourdieu. Nessa linhagem de pensamento, a ideia motriz é a de que não se pode pensar o espírito separado do corpo.

${ }^{60}$ Informações obtidas com prof. François Bonvin. 
interiorização das possibilidades objetivas nesse mundo. E o indivíduo tem esse sentido do jogo: ele pertence a um espaço, já interiorizou completamente as possibilidades que são suas nesse espaço social. Na sociologia bourdieusiana, a compreensão das disposições, do habitus de cada um (as maneiras de ser e agir no mundo) só pode ser avaliada mediante a percepção junto ao grupo; ou seja, ao indivíduo só é possível enxergar-se por intermédio das objetivações dos outros. Pode-se dizer que ocorre, assim, uma identificação pelos outros ${ }^{61}$. O que o autor empenha fazer é uma sociologia relacional.

O autor, por vezes, é acusado de elaborar um tipo de automatismo - a ação do habitus (que é toda a história incorporada) assemelhar-se-ia a automatismo -, mas, ao contrário, é possível perceber que há espaço para a reflexividade nos seus conceitos e na sua teoria. Senso prático, habitus, disposição estão indissociavelmente no corpo do sujeito, na parte consciente (a estratégia usada pelo agente, por exemplo, seria um "cálculo" mais consciente) e na parte nãoconsciente ${ }^{62}$.

\footnotetext{
${ }^{61}$ Nessa direção, é preciso lembrar que o conceito de campo é muito importante no processo de objetivação - objetivar o mundo social (campo); objetivar o sujeito da objetivação (uma postura reflexiva no jogo, no sentido de não achar que o observador sabe mais que o observado). Ou seja, de um lado, o mundo social precisa ser objetivado e, de outro lado, é necessário objetivar o sujeito da objetivação, refletir sobre sua própria prática, pois não se está fora do jogo - em Homo Academicus (1984), livro dedicado ao campo universitário, o autor trata da necessária objetivação daqueles que objetivam. A reflexividade seria, destarte, insistir na objetivação do sujeito da objetivação, visto que o sujeito não plana no mundo social, ao contrário, ele está observando o mundo a partir de uma determinada posição: "Se o sociólogo tem algum privilégio, não é o de ficar pairando acima daqueles aos quais ele classifica, mas de se saber classificado e de saber mais ou menos onde se situa nas classificações" (BOURDIEU, 1983b, p. 58). Nesse sentido, segundo Pinto (2000, p. 32), Bourdieu e Foucault aproximam-se na medida em que defendem uma relação crítica ou reflexiva com o saber: "Se há uma postura que ambos rejeitam é a do cientista como dono de uma autoridade inconteste; eles compartilham, até certo ponto, a idéia de que o progresso da racionalidade é indissociável de uma análise das formas mais ou menos brandas de despotismo da razão".

${ }^{62}$ Segundo François Bonvin (informação verbal), se é ação do habitus ou se é ação reflexiva não é possível concluir sem pesquisar profundamente. O fato é que se deve ter em mente que só se pode atribuir à ação reflexiva o que não foi possível atribuir ao efeito da ação prática, do habitus.
} 


\subsubsection{Capital}

Bourdieu figura o espaço social com as formas de capital: capital cultural ${ }^{63}$, capital econômico, capital simbólico. Segundo o autor, "o espaço social é construído de tal modo que os agentes ou os grupos são aí distribuídos em função de sua posição nas distribuições estatísticas de acordo com os dois princípios de diferenciação [...] o capital econômico e o capital cultural” (BOURDIEU, 1996b, p. 19, destaque do autor). As formas e a estrutura do capital estão diretamente relacionadas com o habitus (a incorporação não-consciente de todas as chances que se tem na vida - chances positivas, chances negativas, isto é, todas as limitações).

O habitus possui quatro dimensões ${ }^{64}$ : a disposicional, a distribucional, a econômica e a categorial. A primeira se subdividiria ainda em dimensão praxiológica (sentido de orientação social) e dimensão afetiva (aspirações, gostos), a qual deixa de ser vista como mera subjetividade, passando a ser encarada como "objetividade interiorizada" 65 . A segunda capta o que é dissimulado pelo economismo espontâneo: "A necessidade de trabalhar em termos de ordem e distribuição" (PINTO, 2000, p. 39 ), em termos de dominantes e dominados. A terceira dimensão ("econômica") 66 concerne aos diferentes tipos de capital (entretanto, trata-se de um capital que não está relacionado ao cálculo) ${ }^{67}$. A última dimensão diz respeito ao "trabalho lógico de ordenação do mundo a partir de um pequeno número de esquemas generalizáveis e transponíveis". Sabe-se que existem as oposições do mundo social, mas elas apresentam-se sob a forma transfigurada de classificações (cognitivas, éticas e

${ }^{63}$ Segundo Bourdieu $(2008$, p. 79 ,) no interior do capital cultural há subespécies, tais como o capital literário, científico e jurídico-econômico.

${ }^{64}$ Tal distinção, segundo Pinto (2000, p. 41), deve ser feita em caráter de exposição, porquanto, tais dimensões acham-se "estreitamente associadas no trabalho empírico". Esse autor fala em quatro dimensões do habitus (disposicional, distribucional, econômica e categorial). François Bonvin (informação verbal) enfatiza as duas primeiras.

65 Toda escolha, segundo Bourdieu, tenderia a reproduzir as relações de dominação, visto que os sistemas de classificação relacionam-se a condições sociais e a estrutura objetiva de distribuição dos bens materiais e simbólicos se dá de forma desigual.

${ }^{66}$ Segundo Pinto (2000, p. 40), as conceituações de habitus - realizadas mediante os trabalhos de etnologia cabila e de sociologia da cultura e da educação, os quais trazem à tona as dimensões disposicional e distribucional do habitus, respectivamente - "induziam a substituir as diferentes formas de intelectualismo científico pela linguagem da economia, que justifica o recurso a noções tais como interesse, estratégia ou capital".

${ }_{67}$ Assim, em contraposição ao intelectualismo científico, o autor procura construir a economia dos bens simbólicos. 
estéticas). Trata-se aí de levar em consideração os mecanismos impessoais de produção dos produtores, os quais são "invisíveis por serem interiorizados e coletivos" ${ }^{8}$. A despeito da divisão metodológica dessas dimensões, elas andam juntas, ou seja, não é possível falar somente do habitus substancializado, ou seja, só falar dos gostos, há também as dimensões distribucional, "econômica" e categorial.

Todos estão enredados no jogo, todos estão encaixados em sistemas distributivos. O mecanismo distributivo é devolvido aos indivíduos na forma corporal, mental, classificatória. Ele é uma forma desigual de distribuição de vantagens. A noção de campo trabalha com outra noção, que é a de tempo. O campo chama atenção para o que vem atrás, para os capitais herdados. Está presente a ideia de trajetória do agente: mobilizar o passado, o presente e o futuro. O habitus é o produto da distribuição social e reforça essa posição. Assemelha-se a um círculo: o indivíduo é formado pelas estruturas e essas estruturas continuam porque ele (o indivíduo) passa a funcionar assim.

Na medida em que se tem o habitus, o que pensar, portanto, da noção de consciência coletiva concebida por Durkheim? Na verdade, é possível valorizar a ação individual "sem hipostasiar o social numa entidade como a "consciência coletiva' durkheimiana, solução falsa de um problema verdadeiro" (BOURDIEU, 2001, p. 191, aspas do autor). Tal ideia deixa de ser coerente, porquanto o sentido prático é que proporciona a ação comum entre os agentes, os quais têm uma ação com condutas orquestradas sem maestro, já que este é uma estrutura interiorizada que vai estruturando.

Sistema de disposições duráveis, estruturas estruturadas predispostas a funcionarem como estruturas estruturantes, isto é, como princípio que gera e estrutura as práticas e as representações que podem ser objetivamente 'regulamentadas' e 'reguladas' sem que por isso sejam o produto de obediência a regras, objetivamente adaptadas a um fim, sem que se tenha necessidade da projeção consciente deste fim ou do domínio das operações para atingi-lo, mas sendo, ao mesmo tempo, coletivamente orquestradas sem serem o produto da ação organizadora de um maestro. (IDEM, 1972, p. 175, aspas do autor e destaque nosso).

\footnotetext{
${ }^{68}$ Nesse sentido, é necessário que a sociologia esteja atenta às categorias imanentes às práticas, pois só assim será possível compreender "a experiência indígena dos agentes" (PINTO, 2000, p. 41). Tal postura evitaria o erro de atribuir-Ihes "uma espécie de lucidez sapiente a respeito de si próprios" (IBIDEM).
} 
Outra questão que deve ser lançada ${ }^{69}$ : se tudo acontece com esse sentido prático interiorizado que vai dando os esquemas de percepção da situação, de avaliação e de ação, é possível dizer que as pessoas fazem sempre a mesma coisa? Como é possível falar em mudança nesse contexto?

\subsubsection{Campo}

A noção de "campo" foi introduzida por Pierre Bourdieu, inspirado em Max Weber: "A primeira elaboração rigorosa da noção [de campo] saiu de uma leitura do capítulo Wirtschaft und Gesellschaft consagrado à sociologia religiosa" (BOURDIEU, 2007 , p. 66, destaque do autor). Entretanto, onde Weber elabora tipologias (sacerdote, profeta, feiticeiro), Bourdieu dinamiza e afirma tratar-se de campo no qual ocorrem diferentes momentos da concorrência. Mediante "uma crítica da visão interacionista das relações entre os agentes sociais proposta por Weber", o autor propõe "uma construção do campo religioso como estrutura de relações objetivas"; com isso ele pretendia explicar "a forma concreta das interações que Max Weber descrevia em forma de uma tipologia realista" (IBIDEM).

Pode-se perceber que o autor parte de uma perspectiva metodológica diferente. Bourdieu evita ficar preso ao que ele chama de "visão interacionista das relações entre os agentes", a qual, segundo ele, tende a disfarçar as relações objetivas entre as posições que estes mesmos agentes ocupam e que determinam a forma de tais interações ${ }^{70}$. Assim como o tipo ideal weberiano, mutatis mutandis, o campo é um modelo de análise, ele não é a realidade. Entretanto, a noção de campo é tomada como um sistema de relações sociais, não são relações entre agentes, mas relações entre posições ${ }^{71}$ (que esses agentes ocupam no campo). Desse modo, os campos apresentam-se como "espaços estruturados de posições (ou de postos)

\footnotetext{
${ }_{70}^{69}$ Questão colocada ao longo do Minicurso proferido por François Bonvin (informação verbal).

70 "A fim de eliminar totalmente as dificuldades encontradas por Max Weber, é necessário operar uma segunda ruptura e subordinar a análise da lógica das interações [...] à construção da estrutura das relações objetivas entre as posições [...]" (BOURDIEU, 1999, p. 81, destaques do autor).

${ }^{71}$ As posições são mais importantes do que as interações quando se pensa em campo, o qual não é o resultado das ações individuais dos agentes. As estratégias dos agentes normalmente estarão orientadas em função da posição ocupada. Pode-se perceber nessa reflexão uma oposição clara à perspectiva weberiana, a qual, no seu esquema relacional entre especialistas e leigos, entende as relações como sendo intersubjetivas e pessoais.
} 
cujas propriedades dependem das posições nesses espaços, podendo ser analisadas independentemente das características de seus ocupantes (em parte determinadas por elas)" (BOURDIEU, 1983b, p. 89). Ao descrever o espaço social como um campo, a intenção de Bourdieu (1996b, p. 50) é apresentá-lo como um campo de forças e um campo de lutas. O primeiro, no sentido de uma necessidade que se impõe aos agentes que nele estão envolvidos. O segundo, no sentido de que no seu interior "os agentes se enfrentam, com meios e fins diferenciados conforme sua posição na estrutura do campo de forças, contribuindo assim para a conservação ou a transformação de sua estrutura" (IBIDEM). Ou seja, o campo abarca essas duas possibilidades.

Apesar de rupturas em relação a alguns aspectos da conceituação weberiana, para a confecção desse modelo de análise foi indispensável recorrer a outros aspectos desta mesma teoria, a qual ajuda a pensar a vida cultural. Assim como Weber, Bourdieu, mutatis mutandis, traz à tona os interesses materiais e ideais daqueles que fazem parte do campo $^{72}$. Ao contrário do marxismo e do estruturalismo, que tratam de uma lógica interna associada a constrangimentos externos, o autor propõe um duplo movimento e a ideia de campo seria esse duplo movimento. Em sua análise, Bourdieu privilegia a autonomia dos diferentes campos, opondo-se assim a um determinismo econômico, pois, segundo ele, o que conta para a dinâmica do campo é - muito mais que o desenvolvimento econômico - o seu trabalho interno (BOURDIEU, 1999, p. 37) ${ }^{73}$. No caso do campo religioso, seguindo os passos de Weber, o autor confirma haver um elemento comum que está ausente tanto da alternativa da autonomia absoluta do campo quanto da alternativa que reduz o religioso à influência direta das estruturas sociais: o trabalho religioso realizado pelos produtores ${ }^{74}$ para responder às necessidades de certos grupos

\footnotetext{
$72 \mathrm{O}$ weberianismo de Bourdieu reside na questão do nexo entre ideias e comportamento econômico muito presente em Weber (MICELI, 1999, LI) e para o qual ele procura dar um novo tratamento sistemático. Segundo Bourdieu (1996b, p. 120), "Weber lembra que, para compreender a religião, não basta estudar as formas simbólicas de tipo religioso, como Cassirer e Durkheim, nem a estrutura imanente da mensagem religiosa, do corpus mitológico ou dos 'discursos', como os estruturalistas; ele se detém nos produtores da mensagem religiosa, nos interesses específicos que os animam, nas estratégias que empregam em suas lutas".

${ }^{73}$ Nesse caso, ele falava do campo religioso e de seu trabalho interno, no qual estão presentes "a ação convergente (apesar da concorrência que os opõe) do corpo sacerdotal (com os interesses materiais e simbólicos que thes são próprios) e das 'forças extra-sacerdotais', vale dizer, as exigências religiosas de certas categorias de leigos e as revelações metafísicas ou éticas do profeta" (BOURDIEU, 1999, p. 37).

${ }^{74} \mathrm{Na}$ gênese histórica de um corpo de agentes especializados: aí reside, segundo Weber, a autonomia relativa da religião.
} 
sociais. Análises que procuram relacionar as obras à visão de mundo ou aos interesses sociais de uma classe social são rechaçadas:

Foi contra essa espécie de curto-circuito redutor que desenvolvi a teoria de campo. De fato, a atenção exclusiva às funções levava a ignorar a questão da lógica interna dos objetos culturais, sua estrutura como linguagens; mas, mais profundamente, levava a esquecer os grupos que produzem esses objetos através dos quais eles também preenchem funções. É aqui que Max Weber, com sua teoria dos agentes religiosos, é de grande ajuda ${ }^{75}$. (BOURDIEU, 1996 b, p. 60, destaque do autor).

Com uma teoria da economia dos campos é possível definir, segundo o autor, "a forma específica de que se revestem, em cada campo, os mecanismos e os conceitos mais gerais (capital, investimento, ganho)" (IDEM, 2007, p. 69, destaque do autor) sem cair necessariamente no economismo, uma espécie de reducionismo. Nessa direção, Bourdieu alerta quanto ao fato de que ao desejar compreender realmente o funcionamento de um campo é necessário "subtrair ao absurdo do arbitrário e do não-motivado os actos dos produtores e as obras por eles produzidas e não, como geralmente se julga, reduzir ou destruir" (IBIDEM). Assim, torna-se possível, de fato, captar aquilo que no campo produz a necessidade específica da crença que o mantém, entender "o jogo de linguagem que nele se joga", perceber as coisas materiais e simbólicas em jogo que nele são geradas. A compreensão feita nesses moldes não deve ser vista de forma alguma, segundo Bourdieu, como uma redução. Não se trata de uma transferência do estilo de pensar econômico.

O campo seriam espaços de jogo historicamente constituídos, com suas instituições específicas e suas leis próprias de funcionamento. No seu interior, existem agentes dotados de um habitus necessário para jogar o jogo. Falar de campo em Bourdieu é falar de habitus, de jogo, de illusio. Trata-se de conceitos relacionais, na medida em que só podem ser compreendidos um em referência ao outro: "é na relação entre o habitus e o campo, entre o jogo e o sentido do jogo, que se engendram os móveis do jogo [...]" (BOURDIEU, 2001, p. 184).

Nos seus escritos, o autor frequentemente insiste na importância de eliminar da prática sociológica a dicotomia objetivo/subjetivo, estrutural/fenomenológico. Será

\footnotetext{
${ }^{75}$ Por outro lado, Weber deixou de perceber que "os universos dos clérigos são microcosmos sociais, campo que tem suas próprias estruturas e suas próprias leis” (BOURDIEU, 1996b, p. 60).
} 
por meio da noção de habitus que ele irá tentar escapar a essa eterna oposição: "A noção de habitus exprime sobretudo a recusa a toda uma série de alternativas nas quais a ciência social se encerrou, a da consciência (ou do sujeito) e do inconsciente, a do finalismo e do mecanicismo, etc" (BOURDIEU, 2007, p. 60). O Habitus fornece uma maneira de encarar o mundo social de forma mais adequada, ele é "uma maneira de escapar dessa alternativa do estruturalismo sem sujeito e da filosofia do sujeito" (IDEM, 2004a, p. 22). A ideia é pensar a relação do agente e o mundo de uma forma nem intelectualista nem mecanicista (IBIDEM); tentar sair do âmbito da filosofia da consciência sem tornar insignificante "o agente na sua verdade de operador prático de construções de objeto" (BOURDIEU, 2007, p. 62). Novamente, o autor evidencia a importância de se fazer o deslocamento entre as diferentes perspectivas teóricas, procurando não se fixar a apenas uma.

O habitus preenche uma função que, em uma outra filosofia, confiamos à consciência transcendental: é um corpo socializado, um corpo estruturado, um corpo que incorporou as estruturas imanentes de um mundo ou de um setor particular desse mundo, de um campo, e que estrutura tanto a percepção desse mundo como a ação nesse mundo. (IDEM, 1996b, p. 144).

Resulta dessas reflexões um novo modo de pensar que o autor denominará praxiologia - "o senso prático é o que permite agir de maneira adequada [...] sem interpor ou executar um 'é preciso', uma regra de conduta" -, em que a intenção é fazer uma articulação dialética entre o ator social e a estrutura social (ORTIZ, 1983, p. 8), trata-se da "interiorização da exterioridade e exteriorização da interioridade" (IBIDEM). É com o intuito de construir uma teoria da prática que Bourdieu traz à tona o conceito de habitus ${ }^{76}$, cuja noção carrega consigo a ideia de um aprendizado passado. O habitus foi criado para dar conta de um paradoxo com relação à conduta dos indivíduos, a qual mesmo sendo orientada em direção a determinados fins não é conscientemente dirigida a/por esses fins. Ele possibilita escapar da ideia de obediência a regras e remete à ideia de estratégia. Na medida em que é um "produto da incorporação da necessidade objetiva", o habitus, enquanto necessidade tornada

\footnotetext{
${ }^{76}$ Bourdieu (2004b, p. 35) afirma que as noções de habitus, de estratégia já estavam presentes, mesmo que implicitamente, desde a origem do seu trabalho intelectual. Já a noção de campo é mais recente, surge nas pesquisas de sociologia da arte e no capítulo consagrado à sociologia religiosa. François Bonvin (informação verbal) afirma que a noção de campo já está presente em um artigo de 1963 sobre o campo intelectual. Nessa perspectiva, Bourdieu começou com o campo intelectual, esse foi o primeiro campo estudado por ele.
} 
virtude, "produz estratégias que, embora são sejam produto de uma aspiração consciente de fins explicitamente colocados", apresentam-se objetivamente ajustadas à situação (BOURDIEU, 2004b, p. 23). Assim, como é possível notar, mediante a noção de habitus, o autor procura revelar que as atitudes dos agentes sociais têm como pilar "algo diferente da intenção" (IDEM, 1996b, p. 164). Isso quer dizer que existem "disposições adquiridas que fazem com que a ação possa e deva ser interpretada como orientada em direção a tal ou qual fim"; porém, não necessariamente é possível afirmar que esta mesma ação tenha por princípio a busca consciente desse objetivo (IBIDEM).

$\mathrm{Na}$ ideia de jogo ${ }^{77}$ - a qual já foi feita referência por ser utilizada para pensar o mundo social -, a estratégia seria "produto do senso prático como sentido do jogo". O bom jogador faz sempre o que o jogo requer, entretanto, o jogo não é um jogo de "obediência mecânica à regra explícita", havendo nele a possibilidade de invenção, de improvisação. O jogo, nesse sentido, pode ser visto como uma atividade regrada que mesmo não sendo obrigatoriamente resultado de uma obediência à regra acata determinadas regularidades: "As condutas adquirem a forma de sequências objetivamente orientadas em referência a um fim, sem serem necessariamente produto nem de uma estratégia consciente, nem de uma determinação mecânica" (BOURDIEU, 2004b, p. 130). O habitus serve para revelar isso, que não é possível colocar o problema em termos de "espontaneidade e coação, liberdade e necessidade, indivíduo e social” (IBIDEM, p. 82). Ou seja, ele deve ser visto como um princípio não escolhido de tantas escolhas ${ }^{78}$. O que, segundo Bourdieu, leva os humanistas ao desespero (IBIDEM, p. 27).

Por intermédio da metáfora do jogo, o autor procura mostrar o seguinte: o jogador em campo possui um número limitado de possibilidades - às vezes mais difícil dependendo da situação dos outros jogadores, dependendo de quem está à sua frente - e ele possui o sentido prático do jogo, escolhendo as situações as mais favoráveis como se fosse instintivamente, não há apenas uma possibilidade. Isso ilustra o habitus: não existe somente um modo de agir. Não é verdadeiro que o habitus faz com que se execute uma mesma ação sempre; ao contrário, o indivíduo

\footnotetext{
${ }^{77}$ Elias (2001), no livro $A$ sociedade de corte, também utilizou na sua teoria a ideia de jogo. Esse autor fala das configurações e dá como exemplo o tabuleiro de xadrez e o jogo de cartas, mostrando que o próprio dessas configurações, assim como da sociedade de corte, é ter um número finito, limitado de possibilidades dentre as quais os jogadores podem escolher.

${ }^{78}$ Portanto, são escolhas entre aspas, visto que são nutridas de constrições.
} 
encontra-se na sua situação, na sua configuração ${ }^{79}$ (que pode ser o campo acadêmico, o campo político, o campo religioso), e ele possui instintivamente esse sentido prático, o que o faz escolher uma entre tantas outras possibilidades, optando pela que lhe parece mais razoável. Tal escolha não é pensada explicitamente.

O habitus como sentido do jogo é jogo social incorporado, transformado em natureza. Nada é simultaneamente mais livre e mais coagido do que a ação do bom jogador. Ele fica naturalmente no lugar em que a bola vai cair, como se a bola o comandasse, mas, desse modo, ele comanda a bola. O habitus como social inscrito no corpo, no indivíduo biológico, permite produzir a infinidade de atos de jogo que estão inscritos no jogo em estado de possibilidades e de exigências objetivas; as coações e as exigências do jogo, ainda que não estejam reunidas num código de regras, impõem-se àqueles e somente àqueles que, por terem o sentido do jogo, isto é, o senso da necessidade imanente do jogo, estão preparados para percebê-las e realizá-las. (BOURDIEU, 2004b, p. 82, destaques nossos).

Esse conceito possibilita, destarte, a superação de oposições como indivíduo e sociedade ${ }^{80}$. O habitus, visto como o "social incorporado, logo individuado", elimina esse tipo de antagonismo. A noção de estratégia foi um instrumento preciso utilizado por Bourdieu na sua intenção de romper com o ponto de vista objetivista e com "a ação sem agente que o estruturalismo supõe (recorrendo, por exemplo, à noção de inconsciente)" (IBIDEM, p. 81). Entretanto, opor-se a ver a estratégia como produto do inconsciente não quer dizer que ela seja um produto consciente e racional: "Os agentes sociais têm 'estratégias' que só muito raramente estão assentadas em uma verdadeira intenção estratégica" (BOURDIEU, 1996b, p. 145). Nem consciente, nem inconsciente, apenas sentido prático do jogo.

O investimento no jogo (illusio) está também, assim como o habitus, presente nesse jogo que é o campo social, seja ele qual for, o científico, o artístico, o religioso, etc.. Os agentes que entram num campo determinado reconhecem a sua importância, não lhe são indiferentes. Mesmo que a ideia seja a de mudá-lo radicalmente, revolucioná-lo, o agente precisa estar de acordo com a sua

\footnotetext{
${ }^{79}$ Elias (2001) utiliza o termo figuração para designar algo próximo ao que Bourdieu entendia por campo. Através desses diferentes conceitos, os dois autores procuram pensar as sociedades humanas como configurações sociais que, no entanto, são transformadas constantemente pelos homens. O objetivo dos dois autores aproxima-se, na medida em que buscam entender como os sistemas simbólicos impactam o mundo social. Utilizando conceitos como habitus e interdependência, Bourdieu e Elias, respectivamente, procuram um meio-termo entre os determinismos sistêmicos e os comportamentos individuais.

${ }^{80}$ Que se apresentam, também, na forma de oposições, por exemplo, entre Durkheim, Marx e Weber.
} 
importância. Nesse sentido, a illusio é "uma cumplicidade profunda com o fantasma coletivo, capaz de garantir a cada um dos membros a experiência de uma exaltação do eu, princípio de uma solidariedade enraizada na adesão à imagem do grupo como imagem encantada de si” (BOURDIEU, 2005, p. 43). Os agentes sociais carregam consigo o respeito e a consideração pelo campo ao qual pertencem.

Há, portanto, uma cumplicidade entre os adversários de um mesmo campo: "Eles se enfrentam, mas estão de acordo pelo menos a respeito do objeto do desacordo" (IDEM, 1996b, p. 141). Os agentes, ocupando posições opostas no campo, possuem um acordo "oculto e tácito" entre si com relação ao fato de que "vale a pena lutar a respeito das coisas que estão em jogo no campo" (IBIDEM). Eles lutam por algo que só tem valor para eles próprios que estão no jogo.

A illusio é ao mesmo tempo condição e produto do funcionamento do campo. Este impõe um comprometimento, exige que se pague um preço para entrar no jogo: “'Que não entre aqui quem não for geômetra', isto é, que ninguém entre aqui se não estiver pronto a morrer por um teorema" (IBIDEM, aspas do autor). Entretanto, a illusio não deve de maneira alguma ser reduzida a uma visão utilitária, ao cálculo consciente "opondo a relação de cumplicidade ontológica entre o habitus e o campo". Pode parecer contraditório, mas, como se viu, na relação com o mundo social, os agentes visam a certos objetivos sem colocá-los como tais (IBIDEM, p. 143).

Substituir uma relação prática de pré-ocupação, presença imediata de um por vir inscrito no presente, por uma consciência racional, calculista, que se coloca objetivos como tais, como possíveis, é abrir espaço para a questão do cinismo, que coloca como tais objetivos inconfessáveis. (IBIDEM, p. 146).

Os agentes, ao possuírem o sentido do jogo, "não têm necessidade de colocar como fins os objetivos de sua prática", pois existe algo que já está inscrito na experiência anterior que não diz respeito a uma consciência transcendental universal. Nessa direção, Bourdieu refere-se a antecipações pré-perceptivas, "induções práticas fundadas na experiência anterior", as quais seriam criadas pelo habitus do sentido do jogo. E esse sentido do jogo é "ter o jogo na pele; é perceber no estado prático o futuro do jogo; é ter o senso histórico do jogo. [...] O bom jogador tem as tendências imanentes do jogo no corpo, incorporadas: ele se incorpora ao 
jogo" (BOURDIEU, 1996b p. 144). Concluindo, ter o sentido do jogo é fazer o que tem que ser feito no momento certo sem "tematizar o que havia que fazer, e menos ainda a regra que permite gerar a conduta adequada" (IDEM, 2007, p. 23).

Discorre-se aqui sobre uma relação com o ambiente que é estruturada e estruturante, uma dupla relação, o agente "se sente em casa no mundo porque o mundo também está nele sob a forma do habitus, necessidade tornada virtude e que requer uma forma de amor da necessidade, de amor fati" ${ }^{81}$ (IDEM, 2001, p. 174, destaques do autor). O mundo torna-se algo evidente não por uma "relação de exterioridade de uma consciência conhecedora" por parte do agente, mas porque este encontra-se com o corpo colado no mundo, "onde ele habita como se fora um uniforme ou um hábitat familiar" (IBIDEM). A relação com o mundo é uma relação de por ele ser possuído.

\subsection{Campo religioso e Campo científico}

Bourdieu (1999) salienta que a formação de um campo religioso autônomo está muito relacionada a uma mudança na infraestrutura social, devida ao processo de industrialização e, consequentemente, ao aparecimento da oposição campo/cidade, trabalho material/trabalho intelectual. Esse seria o espelho das grandes divisões religiosas que viriam acontecer. Aqui o autor relembra algo que Weber já havia salientado quanto à influência de determinada camada social no tipo de religião (de bens e promessas religiosas) a ser desenvolvida. Tal fato pode ser percebido em relação ao obstáculo colocado pelas classes camponesas ao desenvolvimento de uma religião racionalizada, esta só foi encabeçada por uma camada mais urbanizada e economicamente desenvolvida, como a dos comerciantes e artesãos.

Entretanto, a formação autônoma do campo vai muito além de uma vinculação ao processo de industrialização, é que a racionalização da religião possui uma normatividade própria, uma lógica peculiar, que está relacionada ao

81 "O amor fati é o amor pelo que estou determinado a ser, a determinação de amar essas determinações" (PINTO, 2000, p. 116). 
desenvolvimento de um corpo especificamente sacerdotal. O desenvolvimento de um verdadeiro monoteísmo estaria relacionado ao desenvolvimento em direção a uma sociedade com agricultura desenvolvida e com uma divisão de classes, onde os progressos da divisão do trabalho desembocam na divisão do trabalho de dominação e, particularmente, na divisão do trabalho religioso. Portanto, falar em desenvolvimento de um campo levando em conta apenas transformações econômicas faz com que se oculte algo de fundamental importância: a autonomia própria a esse campo, onde a ação convergente (a despeito da concorrência que os opõe) de um corpo sacerdotal, dos leigos e do profeta é que estabelece a dinâmica desse campo (BOURDIEU, 1999, p. 37). Ou seja, a moralização da religião, muito além de estar relacionada a uma situação econômica, está vinculada "às transformações da estrutura das relações de produção simbólica” (IBIDEM).

Na separação das competências de cada campo, coube à religião assumir uma função ideológica, a qual determinará o que merece ou não ser discutido. Isso faz com que ela coloque em prática, segundo Bourdieu (1999, p. 46), “a absolutização do relativo e a legitimação do arbitrário", legalizando assim determinadas posições sociais e reproduzindo a estrutura das relações econômicas e sociais. Ao cumprir funções sociais, a religião não apenas dá resposta às aflições existenciais do indivíduo, mas, além disso, Ihe fornece justificativas quanto à posição social ocupada.

Da mesma forma que no campo religioso, no campo científico ocorre também uma luta por poder e reconhecimento. Isso desenrola-se num processo onde as escolhas científicas estão voltadas para a maximização do lucro científico e, com este, direcionadas ao alcance do reconhecimento dos pares-concorrentes (BOURDIEU, 1983a, p. 126, 127).

A autonomia dos campos é um ponto importante e ao qual se deve estar atento, já havia alertado Bourdieu. Por isso, apesar de o poder ser a alavanca tanto do campo religioso quanto do campo científico, é preciso lembrar que existe algo que é diferenciador desses dois: enquanto a religião é movida pela moral, "o mercado dos bens científicos tem suas leis, que nada têm a ver com a moral" (IBIDEM, p. 133). Isso os coloca em polos opostos. 
O principal indicador do grau de autonomia de um campo é o seu poder de refração, de retradução (BOURDIEU, 2004a, p. 22, destaques nossos), o que significa a capacidade que ele tem de recompor as pressões externas; talvez fosse possível dizer até, a capacidade que ele possui de adequá-las à dinâmica do campo, sem que este seja transfigurado no que ele possui de genuíno.

O campo exerce um efeito de refração (como um prisma): portanto, apenas conhecendo as leis específicas de seu funcionamento (seu 'coeficiente de refração', isto é, seu grau de autonomia) é que se pode compreender as mudanças nas relações entre escritores, entre defensores de diferentes gêneros (poesia, romance e teatro, por exemplo) ou entre diferentes concepções artísticas (a arte pela arte e a arte social, por exemplo), que aparecem, por exemplo, por ocasião de uma mudança de regime político ou de uma crise econômica. (IDEM, 1996b, p. 61, aspas do autor).

Independente do tipo de diálogo que possa ocorrer entre o campo religioso e o campo médico-científico, é necessário verificar até que ponto ele pode ser e é mantido, de forma a não conduzir a conflitos quanto ao lugar ocupado por cada um e a sua especialidade, pois, segundo Bourdieu (1983a, p. 127), os produtores de um determinado campo só reconhecem como clientes seus próprios concorrentes, o que faz com que o valor de um produto só seja reconhecido por outro produtor do mesmo campo. Isso pode ser traduzido da seguinte forma: num campo científico com uma forte autonomia um produtor só pode esperar o reconhecimento (e com este reputação, prestígio, autoridade, competência) do valor dos seus produtos dos outros produtores que "sendo também seus concorrentes, são os menos inclinados a reconhecê-lo sem discussão ou exame". Somente aqueles agentes que estão jogando o mesmo jogo têm condições de apropriar-se dos produtos de um campo (no caso, o científico) e de apreciar seus méritos. Nesse sentido, deve-se lembrar que aquele agente que recorre a uma autoridade exterior ao campo só pode atrair sobre si o descrédito (IBIDEM).

Já no formato de campo religioso proposto por Bourdieu, essa situação não ocorre, visto que os três produtores (sacerdote, mago e profeta) concorrem entre si e são reconhecidos não pelos demais produtores, mas pelos leigos/clientes. Ou seja, uma característica de destaque que pode ser evocada para pontuar as diferenças entre os dois campos é aquela que revela que, ao contrário do campo religioso no qual a produção não é consagrada apenas aos produtores, mas também aos leigos, 
no campo intelectual ela é reservada apenas aos produtores ${ }^{82}$ : "Por mais marcante que seja a ruptura entre os especialistas e os profanos, o campo religioso distinguese do campo intelectual propriamente dito, pois nunca consegue dedicar-se total e exclusivamente a uma produção esotérica, isto é, destinada apenas aos produtores, devendo sempre sacrificar-se às exigências dos leigos" (BOURDIEU, 1999, p. 38). Dito de outro modo, enquanto no campo científico a produção deve ser interessante para os especialistas, no campo religioso, para sobreviver, ela (a produção) deve ser interessante para os leigos, os não especialistas. Essa é a dinâmica a partir da qual se movimentam esses dois campos.

${ }^{82}$ Não que o trabalho do cientista deva ser interessante somente a ele individualmente; ao contrário, ele deve curvar-se às exigências dos seus pares que são também seus concorrentes. 


\section{DELIMITAÇÃO DO RECORTE EMPÍRICO E METODOLOGIA OPERACIONAL}

\subsection{DELIMITAÇÃO DO RECORTE EMPÍRICO}

\subsubsection{A medicina psiquiátrica como objeto da pesquisa}

Tomando como pano de fundo a relação mais ampla ciência/religião, medicina/religião, busca-se verificar como isso se resolve no espaço da psiquiatria. Neste estudo, a opção pela psiquiatria e não por outras especialidades da medicina deve-se ao fato da forte relação que ela manteve com a religião desde tempos remotos $^{83}$. Houve momentos da história, especialmente na Idade Média, em que embora a psiquiatria ${ }^{84}$ não se caracterizasse ainda como um ramo da medicina - as doenças mentais eram vinculadas ao misticismo e à religião. Nesse contexto, os debates religiosos e metafísicos substituíram as tradições empíricas da medicina (LOTUFO-NETO, 1997, p. 324), fazendo com que as ações médicas, tanto no que diz respeito às doenças físicas quanto mentais, ficassem submetidas a ideias demonológicas. Assim, o enfoque dado às doenças era de caráter mágico-religioso, atribuindo-se a sua causa à presença de demônios que precisavam ser expulsos em rituais próprios (OLIVEIRA, 1985, p. 21).

Com o tempo, essa postura foi sendo substituída por outra que parecia corresponder melhor aos fatos; surgiram então novas maneiras de lidar com os

\footnotetext{
${ }^{83}$ Soma-se a isso a necessidade de delimitar o campo da pesquisa: o HCFMUSP, o qual é composto por inúmeras áreas de especialização dentro das quais é grande o número de profissionais entre especialistas (médicos, enfermeiros) e funcionários, sem contar os pacientes que circulam pelo hospital.

${ }_{84}$ Michel Foucault mostra o momento da ruptura em que surge o saber e o poder psiquiátricos. Em obras como História da loucura (2005), Nascimento da clínica (2006) e Microfísica do poder (1979) nesta última, na parte que trata de questões de saúde -, ele mostra claramente que é na modernidade que surge o modelo psiquiátrico tal qual se conhece hoje. Antes disso, no que ele chama de era clássica, tem-se os prisioneiros da nau dos loucos: "[...] barcos que levavam sua carga insana de uma cidade para outra. Os loucos tinham então uma existência facilmente errante. As cidades escorraçavam-nos de seus muros; deixava que corressem pelos campos distantes, quando não eram confiados a grupos de mercadores e peregrinos" (FOUCAULT, 2005, p. 9).
} 
males do corpo e da alma, essa última não tendo mais o valor excessivo que the imputava a Igreja (OLIVEIRA, 1985, p. 21). A partir de alguns depoimentos dos ministros religiosos do HCFMUSP ${ }^{85}$, é possível perceber em que nível desenrola-se essa discussão, como atualmente eles lidam com essa questão, a qual passa a ser considerada primeiramente no âmbito das explicações científicas:

Pelo que eu conheço até hoje, o que me falaram que era coisa demoníaca sempre tinha explicações humanas e científicas, dava para se explicar através da psiquiatria, da medicina, da ciência. [...] até o pessoal da psiquiatria fala: "eu expulso demônio com Aldol!". (AR1).

Eu não vou invadir o campo de ação do outro, a competência do outro, eu não vou chegar num meio científico que é uma área psiquiátrica e dizer "tudo aqui é diabo". Eu acho o seguinte: se nós estamos dentro de um hospital, aquilo que é mais importante, aquilo que deve ser considerado primeiro é o que a ciência determina [...]. (AR3).

É interessante ver como, nesses trechos, a influência do discurso científico sobre o discurso religioso fica evidente. Os ministros religiosos mostram-se dispostos a trabalhar de acordo com as normas científicas, construindo um discurso, pelo qual procuram enfatizar a prioridade que as explicações científicas têm, atualmente, na área médica em detrimento das religiosas ${ }^{86}$. Ou seja, a religião e seus especialistas estão atentos em relação aos saberes da ciência. No mundo moderno, onde já não reina mais, a religião parece acatar as opiniões mundanas e aceitar os diagnósticos que outros saberes fazem da experiência humana em sociedade.

Isso indica a verdadeira inversão de poder que houve de alguns séculos até hoje. Ao voltar-se ao passado, é possível rememorar como a verdade religiosa era

\footnotetext{
${ }^{85}$ Realizou-se uma pesquisa preliminar para levantamento de questões para o projeto de pesquisa. Utilizar-se-á a sigla AR significando "autoridade religiosa" para denominar os ministros religiosos entrevistados.

${ }^{86}$ Ainda que tenha sido possível observar (inicialmente) a adequação das crenças, dos discursos religiosos aos preceitos médicos, o que seria suficiente para confirmar a hegemonia do campo médico, ainda assim é pertinente avaliar os moldes em que acontece a relação psiquiatria/religião. $O$ fato da soberania do campo psiquiátrico em detrimento do campo religioso não descarta a relevância de se pensar as suas características, o seu formato, os conflitos. Tal relação não deve ser vista como imutável, ela está sujeita a mudanças (mesmo que não radicais) que podem resultar num novo desenho para os dois campos.
} 
predominante, se não exclusiva, nos hospitais ${ }^{87}$. Foucault (1979) relembra, em Microfísica do Poder, como funcionava o sistema de poder no interior dos hospitais. O autor observa que, até meados do século XVIII, o pessoal religioso era quem tinha a exclusividade dentro dos hospitais, cuja função era a de garantir a vida cotidiana, a salvação e a alimentação dos internos. Desse modo, a presença do médico era algo irregular e instável, já que este era submetido administrativamente ao pessoal religioso que, a qualquer momento, podia despedi-lo. Esse comportamento perpetuou-se até um passado não muito distante, quando a instância religiosa continuou a predominar.

Relações de poder entre campos sociais distintos foram disputadas ao longo dos tempos. No decorrer da história, o convívio entre psiquiatria e religião foi tumultuoso, variando de alianças a disputas por poder, de tentativas de colaboração a afastamentos (LOTUFO-NETO, 1997, p. 309). A luta por poder é algo presente tanto no interior dos campos quanto na relação entre eles, já havia considerado Bourdieu (1999). Esse autor, ao introduzir a noção de "campo", faz notar de que forma ocorre o seu funcionamento, evidenciando uma dinâmica de disputas, imposições e coerções responsáveis pelo seu movimento constante ${ }^{88}$.

Hoje, porém, os acontecimentos desenrolam-se num contexto em que a ciência médica coloca-se à frente como detentora do poder no interior dos hospitais. No caso do HCFMUSP, a presença dos religiosos é assegurada, de um lado, pela aceitação por parte de alguns médicos que consideram importante o trabalho religioso e, de outro lado, em função do acatamento das normas científicas pelos religiosos. Entretanto, resta saber quais os imponderáveis dessa relação; aparentemente o que salta aos olhos é isso, mas somente um aprofundamento maior, por intermédio da análise de entrevistas, possibilita afirmar em que moldes as

\footnotetext{
${ }^{87}$ Importante lembrar aqui que até o século XVIII, Foucault aborda essa questão em História da Loucura, não existia hospital tal qual se conhece hoje. O que havia eram depósitos de pessoas, as quais eram indiferenciadas (colocavam-se juntos, mendigos, criminosos, pessoas que não tinham onde morar) e estavam lá para morrer. Como aponta em Microfísica do Poder, o sentido de hospital não era o mesmo que passou a ter como lugar de tentativa de cura, de restabelecimento: "O hospital como instrumento terapêutico é invenção relativamente nova, que data do final do século XVIII" (FOUCAULT, 1979, p. 99).

${ }^{88}$ Com relação à religião, ele irá tomar como exemplo a Europa cristã tradicional para conduzir uma análise que mostra o conflito e as tensões que ocorrem numa situação de monopólio entre Igreja e seita e, no interior da instância religiosa, entre especialistas e leigos. O palco do conflito é um contexto onde o Estado legitima as ações da religião (no caso, a católica) e favorece assim o monopólio por parte da instância religiosa que se considera a porta-voz de um saber e de práticas legítimas (BOURDIEU, 1999).
} 
relações acontecem e como as posições que cada um ocupa nesse espaço (e as tomadas de posição que delas resultam) podem influenciar e serem responsáveis pelos acontecimentos.

\subsubsection{A psiquiatria no campo médico brasileiro}

Com intuito de esboçar um breve panorama da mentalidade do campo psiquiátrico no Brasil, lança-se mão aqui do trabalho de Jurandir Freire Costa que, em História da Psiquiatria no Brasil, converge seu olhar analítico para o caso paradigmático do pensamento da Liga Brasileira de Higiene Mental (LBHM) nos anos 20 e 30. Mediante tal recorte, o autor demonstra como expectativas normativas socioculturais podem ser responsáveis por fornecer a base para a solidificação de algumas práticas no campo da psiquiatria. Acontece que, à medida que adota a ideia de prevenção na prática psiquiátrica, a Liga faz com que a psiquiatria se transforme num universo de polemização dos motivos do atraso social brasileiro. Cenário no qual ocorre uma união perfeita entre o autoritarismo normativo do discurso psiquiátrico e políticas como a de "saneamento moral" e aprimoramento da raça, como a eugenia e a crítica à miscigenação. Com essa reflexão, Costa procura expor enfaticamente a ligação que há entre o tipo de tratamento psiquiátrico e os modelos culturais de conduta e valoração.

Como pontua o autor, ao analisar a LBHM, o psiquiatra corre grandes riscos quando tende a se imaginar apenas homem de ciência esquecendo-se de que "é homem de seu tempo", desconhecendo a "história de suas contingências" (COSTA, 2007, p. 19). É necessário estar-se atento à cientificidade e não cientificidade das noções, ao que é exigência da cultura e não da teoria psiquiátrica, tal como foi o caso da prevenção eugênica (IBIDEM, p. 22). A loucura resistia à psiquiatria e "a prevenção eugênica foi o esforço desesperado do psiquiatra para quebrar essa resistência" (IBIDEM, p. 23). A Liga seria o exemplo do condicionamento histórico das concepções psiquiátricas (IBIDEM, p. 27).

Houve momentos em que, no âmbito da psiquiatria, a relação de saber cedeu à relação de poder. Momento esse em que, em vez de conhecimento, a 
psiquiatria tornou-se um campo de batalha: a questão não era mais possuir um saber sobre a doença mental ${ }^{89}$, mas dominar a qualquer custo a loucura. (COSTA, 2007 , p. 23). A psiquiatria da Liga foi assim e a psiquiatria atual parece assemelharse a esse modelo, na medida em que "a idéia de prevenção impregna o discurso psiquiátrico moderno". Por isso é importante frisar como a psiquiatria, por vezes, pode estar sujeita às exigências da cultura (IBIDEM).

A verdade é que toda psiquiatria está inevitavelmente comprometida com o social, na medida em que existe uma "determinação histórica das nossas formas de pensar ou lidar com a loucura", ou seja, é preciso ter a convicção de que "não há conhecimento sem interesse" (IBIDEM, p. 28). Está-se falando claramente da importância dos contextos históricos na produção de teorias (IBIDEM, p. 30), no caso da psiquiatria preventiva dos anos 70 e a psiquiatria da Liga dos anos 30 , o comprometimento com finalidades político-sociais. Tanto uma como a outra fracassaram devido a tal comprometimento e em função da crença na unidade do saber psiquiátrico

Valendo-se da frouxa analogia existente entre os fundamentos do conhecimento psiquiátrico e a pretensa lógica universal que orienta a investigação científica - leia-se ciências físico-químicas -, os psiquiatras acreditaram encontrar a síntese teórico-prática de que necessitavam, pirateando os modelos de prevenção da medicina orgânica ou hipertrofiadas noções como a de indivíduo enquanto unidade biopsicossocial (IBIDEM, p. 31, destaque do autor).

Para Costa (2007, p. 31) é um engodo pensar que existe unidade do conhecimento psiquiátrico, assim como "não existe unidade da ciência ou da lógica científica". Essa pretensa unidade pode ser caracterizada quando a psiquiatria brasileira, a partir dos anos 30 , definiu os parâmetros do saber psiquiátrico moderno em torno de três modalidades de discurso: o organicista, o preventivista, e o psicoterápico. Eles "foram criados e legitimados em função de estratégias de poder/saber diversas: reconhecimento científico, prestígio político-profissional;

${ }^{89}$ Szasz $(1979$, p. 12, 14) considera o conceito de doença mental "vago, caprichoso, e em geral insatisfatório". Não obstante tenha sido útil no século XIX, atualmente esse conceito é "cientificamente inútil e socialmente prejudicial". Ainda que o autor sustente a ideia de que a doença mental é um mito, ele afirma não ser sua intenção "desmascarar a psiquiatria" como fazem muitos estudiosos. Ele acredita que a psiquiatria possa ser uma ciência, mas não admite que as pessoas devam ser recuperadas de uma "doença", ao contrário necessitam ser orientadas a "se conhecerem a si próprias, aos outros, e à vida". 
interesses corporativos, econômicos, etc." (COSTA, 2007, p. 31). Com isso, segundo o autor, pode-se perceber que o conhecimento científico é, na teia institucional, um entre tantos elementos que dá suporte ao pensamento psiquiátrico que podem ser responsabilizados pelas percepções históricas e contingentes da loucura ou da saúde/doença mental (IBIDEM).

No entanto, a psiquiatria não pode ser resumida ou definida a partir de algumas noções, pois cada uma de suas práticas é concebida para dar conta de um aspecto da vida psíquica. Não se pode, portanto, subordinar "a totalidade das práticas envolvidas no campo psiquiátrico a um único critério normativo de cientificidade, a uma única teoria e, ainda menos, a duas ou três noções tiradas da algibeira" (IBIDEM, p. 32).

Apesar de todas as críticas passíveis de serem feitas a um saber psiquiátrico que se encontra preso a exigências culturais ou a finalidades político-sociais, não é correto que se atenha a uma responsabilidade teórico-técnica, culpabilizando, como diria Costa, "o elo mais fraco da cadeia, deixando impunes os interesses dos industriais da doença e seus representantes nos aparelhos estatais de gestão da loucura" (IBIDEM, p. 36). Não é possível culpar apenas técnicos, assim como não é possível culpar apenas o Estado. Há uma cumplicidade científica da psiquiatria - e Costa irá indicar isso partindo do caso da Liga - com as razões de Estado (IBIDEM).

No Brasil, os doentes mentais, especificamente os habitantes do Rio de Janeiro até a segunda metade do século XIX, não eram beneficiados com nenhuma assistência médica específica. Normalmente, quando não eram despejados nas prisões por vagabundagem ou perturbação da ordem pública, "os loucos erravam pelas ruas ou eram encarcerados nas celas especiais dos hospitais gerais da Santa Casa de Misericórdia" (IBIDEM, p. 39). A partir de 1830 alguns médicos começam a demandar a construção de um hospício para alienados e apenas em 1852 é inaugurado o primeiro hospital psiquiátrico brasileiro, o qual teve o decreto de sua fundação assinado pelo imperador Pedro II. Nesse momento o hospício era confiado aos religiosos da Santa Casa de Misericórdia, somente com a instauração da República em 1890 ele é separado da administração da Santa Casa e coloca-se sob a tutela do Estado (IBIDEM, p. 40). 
Especificamente em 1912, a psiquiatria passará a ser uma especialidade médica autônoma, e a partir de então ocorre um aumento considerável de locais destinados aos doentes mentais. Graças a Juliano Moreira ${ }^{90}$, será inaugurada uma psiquiatria "cujos fundamentos teóricos, práticos e institucionais constituíram um sistema psiquiátrico coerente" (COSTA, 2007, p. 42), visto que até esse momento ocorria apenas a reprodução do discurso teórico da psiquiatria francesa e, também, o cumprimento das regras ditadas por leigos ou religiosos que administravam os hospitais (IBIDEM).

Apesar da revolução que advém com Juliano Moreira e seus seguidores reconhecimento jurídico da psiquiatria, desenvolvimento da pesquisa psiquiátrica, consolidação dos mecanismos institucionais de formação de outros psiquiatras (internato psiquiátrico) -, evidencia-se "uma extrema vulnerabilidade diante dos preconceitos culturais da época" (IBIDEM, p. 42). Associado a isso está o fato de não conseguirem delimitar o campo próprio à psiquiatria, o que justamente induzia a que esses profissionais confundissem problemas psiquiátricos e problemas culturais. Nesse tipo de raciocínio, o psíquico e o cultural explicavam-se "pela hipótese de uma causalidade biológica que, por sua vez, justificava a intervenção médica em todos os níveis da sociedade" (IBIDEM).

Para Juliano Moreira, por exemplo, a doença mental, a situação social dos imigrantes recém-chegados ao Brasil ou a constituição étnica do povo brasileiro relevavam do mesmo sistema de interpretação biologizante proposta pela psiquiatria organicista alemã. (IBIDEM, destaque do autor).

\footnotetext{
90 Juliano Moreira (1873-1933) é normalmente designado como fundador da disciplina psiquiátrica no Brasil. Moreira procurou fazer parte de linhas de pensamento - um exemplo seria a escola alemã de Kraepelin - que naquele momento (primeiras décadas do século $X X$ ) eram o modelo de modernização tanto no âmbito teórico da psiquiatria quanto na prática asilar. Ao mesmo tempo em que se baseava em pressupostos organicistas, Moreira divergia da ideia corrente na época e defendida pela maior parte de seus colegas quanto à atribuição da degeneração do povo brasileiro à mestiçagem e quanto à questão de que existiriam doenças mentais próprias dos climas tropicais. Em consonância com a medicina das primeiras décadas do século $\mathrm{XX}$, que buscava dirigir o processo de modernização e sanitarização do País, Moreira tinha como pressuposto que o papel primordial da psiquiatria era promover a profilaxia, a higiene mental e a eugenia. Assim ele desenvolverá seu trabalho em prol de uma ciência psiquiátrica brasileira a serviço da nação. Mediante ações como higiene, educação e saneamento, ele acreditava ser possível tanto recuperar quanto prevenir doenças nos brasileiros. Ainda que possa ser alvo de críticas por semelhante projeto, não é possível deixar de creditar a Moreira uma grande inovação no campo psiquiátrico, visto que entre outras coisas foi ele o defensor da reformulação da assistência psiquiátrica pública e da promulgação da primeira lei de assistência a alienados no Brasil (1903).
} 
Tal biologicismo tinha fundamentos ideológicos e não científicos. Os eugenistas procuravam justificar as suas ações associando-as ao pensamento psiquiátrico organicista (COSTA, 2007, p. 56). Portanto, ideologia eugênica e biologicismo organicista impediam que os psiquiatras da época estivessem atentos a outras variáveis importantes que compõem e determinam a demanda de atenção médico-psiquiátrica (IBIDEM, p. 132).

É necessário cotejar essas reflexões feitas por Costa (2007) com a psiquiatria atual, mediante a situação da prática psiquiátrica compartilhada no IPQ do HCFMUSP pelos profissionais de saúde mental. A realidade descrita por Costa estende-se aos dias de hoje; no entanto, até onde ela é contestada é algo que se deve tentar elucidar ao longo deste trabalho.

\subsubsection{Hospital das Clínicas da FMUSP (HCFMUSP) e Instituto de Psiquiatria (IPQ)}

Inaugurado em 19 de abril de 1944, o HCFMUSP é definido como uma autarquia estadual que, de um lado, encontra-se vinculada à Secretaria de Estado da Saúde "para fins de coordenação administrativa" e, de outro lado, está ligada à Faculdade de Medicina da USP com objetivos de ensino, pesquisa e prestação de ações e serviços de saúde de alta complexidade destinados à comunidade (Disponível em: <http://www.hcnet.usp.br> Acesso em: 12/03/08).

Três instâncias compõem o seu corpo administrativo: o Conselho Deliberativo, a Diretoria Clínica e a Superintendência. A primeira compõe-se de professores titulares da Faculdade de Medicina e tem como função estabelecer as normas de procedimento das atividades médico-hospitalares, de pesquisa e de cooperação com os cursos da FMUSP. A segunda tem como tarefa a coordenação das atividades médicas e o apoio às atividades de ensino e de pesquisa científica das unidades hospitalares. Já à superintendência ${ }^{91}$, que é o órgão superior de direção executiva, cabe a coordenação e o controle das atividades de administração.

\footnotetext{
${ }^{91} \mathrm{O}$ superintendente é nomeado pelo governador do Estado.
} 
O IPQ foi construído na década de 1940 e inaugurado em $1952^{92}$ e é um dos seis Institutos que constituem o quadro do HCFMUSP ${ }^{93}$. O Instituto é considerado de grande importância na formação dos médicos, pois é por intermédio dele que os profissionais de saúde mental realizam seus estágios, especializações, pósgraduações, residências. Assim sendo, ele é a base operacional do Departamento de Psiquiatria da FMUSP. Além do que, nele são conduzidos projetos de pesquisa em parceria com os demais Institutos e Departamentos da FMUSP e do HCFMUSP bem como com outras universidades do País e do exterior. Conta também com o desenvolvimento de importantes programas em áreas como: psicofarmacoterapia, transtornos ansiosos, transtornos do comportamento alimentar, diagnóstico e epidemiologia psiquiátrica, prevenção e tratamento de alcoolismo e abuso de drogas, esquizofrenia, psicoterapias, transtornos do humor, geronto-psiquiatria, psiquiatria infantil, transtornos ligados à sexualidade, etc.

\subsubsection{A capelania religiosa hospitalar como objeto de pesquisa}

\subsubsection{Capelania e assistência religiosa no HCFMUSP}

\section{- $\underline{\text { Católicos e evangélicos }}$}

Desde a sua fundação, já existia no HCFMUSP um trabalho de assistência religiosa. Inicialmente ele restringia-se ao catolicismo apenas, é o que relatam os livros dos registros de crônicas da Capelania: "A capela do hospital foi inaugurada no dia 15 de maio de 1945. O primeiro capelão foi o Cônego Roque Viggiano, auxiliado

\footnotetext{
92 Nesse mesmo ano, foi introduzido o primeiro neuroléptico/antipsicótico (a clorpromazina), acontecimento que revolucionou a psiquiatria (Disponível em: <http://www.hcnet.usp.br> Acesso: 12/03/08).

${ }^{93} \mathrm{O}$ conjunto do IPQ é formado por Laboratórios, Serviços de diagnóstico, Unidades de Internação, tratamento biológico e psicoterapia, Divisão de neurocirurgia funcional, Ambulatórios gerais e especializados, Centro de reabilitação e Hospital-Dia. É composto por cerca de 600 (seiscentos) profissionais de áreas diversificadas, das quais fazem parte médicos, enfermeiros, psicólogos, assistentes sociais, terapeutas ocupacionais, farmacêuticos, laboratoristas, administradores, técnicos (Disponível em: <http://www.hcnet.usp.br> Acesso: 12/03/08).
} 
pelo Pe. Miguel Sanjurjo, que exerceu o ministério no HCFMUSP até 29 de abril de 1960" (Disponível em: <http://www.hcnet.usp.br/adm/care> Acesso em: 12/03/08).

Quem sempre atuou no serviço religioso de capelanias do HCFMUSP foram os padres camilianos (estes fizeram o primeiro contato em 1951). Os padres da Ordem de São Camilo têm como característica fundante cuidar dos doentes e das questões relacionadas à saúde. Entretanto, já em 1952 - na época da criação da capelania -, tendo em vista a necessidade de atender às características espirituais e religiosas específicas dos pacientes e seus familiares, foi requerida a formação do serviço religioso evangélico. A entrada dos protestantes foi quase concomitante a dos católicos e a sua presença no hospital não aconteceu em função apenas de uma "questão de acomodação política, é constitucional” (AR3). Desse modo, o próprio governador da época, em 1952, "abriu um cargo de capelão evangélico que foi devidamente remunerado" (AR3); ou seja, o pastor foi tido como um funcionário do Estado (AR3). A composição do serviço religioso evangélico, segundo AR3, é diversificada ${ }^{94}$. Agregados a esse serviço há os voluntários oriundos das mais diferentes denominações evangélicas (AR3).

Todo o trabalho de assistência desenvolvido, segundo AR3, primou sempre pela liberdade religiosa dos pacientes, procurando rechaçar atuações proselitistas. Sempre houve a preocupação no sentido de respeitar a religião de todos os que eram assistidos.

\section{- O passado e o presente}

Antigamente o serviço religioso centrava-se apenas na figura do sacerdote, o qual se restringia a ministrar sacramentos aos enfermos. Atualmente as coisas mudaram. Ainda que seja dada importância aos sacramentos junto ao doente, o serviço religioso não deve limitar-se apenas a esse tipo de prática: "Os sacramentos, principalmente a unção dos enfermos, perderam espaço dando ênfase à fé e à

\footnotetext{
94 A diversidade, entretanto, parece limitar-se ao campo protestante tradicional. As autoridades que atuavam no momento da pesquisa eram: Reverendo Luís Roberto Pinheiro Chagas, da Igreja Presbiteriana Unida do Brasil, Reverendo João Domingos Alves Filho, da Igreja Presbiteriana Independente e a bacharel em Teologia Professora Stella Souza Rocha, da Igreja Batista.
} 
evangelização; estas incidem no doente e em suas atitudes de vida. A nova concepção de saúde, que inclui o bem-estar psicológico, incorporou o religioso no âmbito da saúde e da terapia" (Disponível em: <http://www.hcnet.usp.br/adm/care> Acesso em: 12/03/08). Desse modo, o papel do religioso deve ultrapassar a questão dos rituais e práticas religiosas específicas.

Nós sempre tivemos essa questão: quando é que o padre e o pastor vão ao hospital? Quando alguém está morrendo. Aqui, por exemplo, eu fico aqui, as pessoas me conhecem, mas quando eu vou atender pacientes fora, em outro hospital, todo mundo fica olhando assustado porque o padre nunca vai. Então, quando vai, é para quem vai morrer. $E$ vai mesmo. Porque aquilo que é rotina... o que é raro é que chama atenção. O que é rotina não chama atenção. (AR1).

Tem sido modificado. Mas, na grande maioria, o que a gente percebe é que padre e pastor estão aqui pra fazer solenidade de Natal, de Páscoa, rezar missa pra quem morreu, fazer um culto de memória para quem morreu. É para isso. (AR3).

São outros os horizontes do serviço religioso. Ele ganha espaço e credibilidade dentro do hospital a partir do momento em que "o doente já não é desmembrado em corpo e alma, como se constituíssem duas partes autônomas". Ao contrário, o sujeito passa a ser encarado como uma unidade indivisível, não sendo mais possível que os cuidados somáticos prescindam da realidade psico-espiritual e vice-versa (Disponível em: <http://www.hcnet.usp.br/adm/care> Acesso em: 12/03/08).

Outra modificação relevante é o fato de o serviço religioso não ser exclusividade do sacerdote (pastor ou padre), há um espaço de destaque para os leigos, o que evidencia a ampliação dos horizontes de atuação da assistência religiosa. Ainda que haja restrições à atuação dos voluntários religiosos, estes são parte do corpo da capelania religiosa e ganham cada vez mais espaço. 


\section{- A assistência religiosa no HCFMUSP e os aspectos jurídico-}

\section{institucionais}

A assistência religiosa nos hospitais, até determinado tempo, era privilegiada em detrimento da assistência médica. Para ser atendido pelo corpo médico, o paciente obrigatoriamente devia passar pela avaliação espiritual de um capelão. Isso mostra o grau de importância dada aos aspectos religiosos outrora. A atenção proporcionada ao universo religioso pode ser visualizada no que diz respeito ao investimento financeiro - concretizado mediante o capricho no tratamento estético que era dispensado à construção dos espaços (capelas) no interior dos hospitais.

O serviço católico [existe no hospital] desde a fundação em 1944, naquela época era muito forte o catolicismo, nenhum doente podia morrer sem a visita do padre. Na Idade Média, nos hospitais tinha uma faixa: "nenhum doente deve ser atendido antes de se confessar". Essa era a condição básica para uma pessoa ser atendida, porque como eles tinham a mentalidade de que a doença vinha do pecado ${ }^{95}$, então não adianta levar você para passar na consulta médica se você está em pecado. (AR1).

O início do serviço religioso, a capelania propriamente dita, foi instituído logo que o hospital foi inaugurado. A primeira parte do hospital a ser inaugurada foi a capela, a primeira parte a ser feita. E o cuidado da capela foi esmerado. Tanto é que há obras de Vítor Brecheret, que são as esculturas; há obras de Di Cavalcanti, que são os vitrôs, os vitrais. Então, o início se deu aí. (AR3).

A assistência religiosa até um período da história - de acordo com Foucault (1979) até o século XVIII - era privilegiada dentro dos hospitais. Isso pode ser notado, segundo Rego (1993), mediante a aprovação em 1776 do estatuto do Hospital dos Lázaros, segundo o qual deveria haver, além do médico, o capelão para assistir espiritualmente os enfermos, os quais não poderiam ser recolhidos ao hospital sem se constar que houvessem confessado.

Ao abordar a medicalização ocorrida no hospital, no sentido de este deixar de ser assistência religiosa e moral e passar a ser assistência terapêutica, Foucault

${ }^{95}$ Conforme consta de Les cahiers protestants, "a doença existe porque o pecado se instalou no mundo. Ela é sempre o sinal de que vivemos em um mundo revoltado contra Deus, bem como lembrança da presença demoníaca" (Les cahiers protestants, 1966, n. 4-5, p. 21-22 apud Laplantine, 2004). 
(1979) aponta para a transferência de poder, a qual passou das mãos dos religiosos às mãos dos médicos, acontecimento este que resulta na organização de um saber hospitalar. Antes, o personagem ideal do hospital não era "o doente que é preciso curar, mas o pobre que está morrendo. É alguém que deve ser assistido material e espiritualmente, alguém a quem se deve dar os últimos cuidados e o último sacramento" (FOUCAULT, 1979, p. 101, destaque nosso). Hoje, no entanto, os objetivos da assistência religiosa não mais estão voltados a tais aspectos.

Atualmente, ainda que não de forma tão entronizada, o papel da assistência religiosa não deixa de ser considerado no interior dos hospitais, o HCFMUSP é um exemplo disso. Ocorre que a religião deixa de possuir uma atribuição de premência e, ao contrário de uma atuação de destaque e de triagem mediante a confissão, Ihe é concedido o papel de complementaridade terapêutica, auxílio. Toda a dinâmica hospitalar passa a se movimentar com ela e apesar dela.

Os assistentes religiosos, pelo regulamento geral do Hospital das Clínicas, estão subordinados diretamente ao Superintendente. Com o intuito de normatizar e especificar as atividades da capelania, os capelães foram convocados pela superintendência a elaborar uma Ordem de Serviço ${ }^{96}$. Nesta foram estabelecidos "detalhes de sua composição jurídica e a criação do Serviço Religioso Católico e do Serviço Religioso Evangélico, para atuarem ecumenicamente" (Disponível em: <http://www.hcnet.usp.br/adm/care> Acesso em: 12/03/08, destaque nosso). Posteriormente, especificamente em 2004, com o propósito de se adequar "ao desenvolvimento da realidade mundial de assistência religiosa hospitalar e às novas leis governamentais que tratam da assistência religiosa em instituições de saúde" (Disponível em: <http://www.hcnet.usp.br/adm/care> Acesso em: 12/03/08), a superintendência convoca novamente os capelães, para formalizar o documento substitutivo à Ordem de Serviço de Janeiro de 1995. Dessa convocação, resulta um novo documento: a Ordem de Serviço n² 25/2004.

Existem algumas atribuições - descritas na referida Ordem de Serviço - que são identificadas pela superintendência como fazendo parte do trabalho de capelania. Especificamente no artigo $8^{\circ}$ desse documento, está colocado de forma explícita que a função dos religiosos e de suas respectivas capelanias é

${ }^{96}$ A ordem de serviço é o documento no qual consta o conjunto de regulamentações a serem seguidas no hospital. 
proporcionar auxílio espiritual e religioso aos pacientes, familiares e funcionários. Dentre as funções destacam-se as seguintes ${ }^{97}$ :

- Manter presença junto aos doentes, procurando oferecer a todos: solidariedade, conforto humano e espiritual, respeitando a individualidade e as convicções religiosas de cada um.

- Ajudar os pacientes para que a passagem pelo hospital sirva para uma revisão e/ou descoberta e aprofundamento do sentido da vida

- Servir de apoio aos familiares de pacientes em situações críticas de sofrimento.

- Desenvolver uma ação de ajuda espiritual, fazendo com que os profissionais de saúde, independente de seu credo religioso, reconheçam os valores espirituais do paciente.

- Garantir a presença da religião junto aos profissionais da saúde ajudando-os a descobrir o valor humano e especial do trabalho.

- Assessorar os profissionais da equipe multidisciplinar na solução de casos em que, de algum modo, estejam implicadas questões de religião ou moral.

Como é possível perceber, no conteúdo do documento, é clara a abertura à participação dos religiosos, seja no que diz respeito à função específica enquanto representantes de uma instância religiosa doadora de sentido, seja no que concerne à atuação relativa ao alívio do sofrimento e à promoção de conforto. A meta principal é a ação que dê relevo ao lado humano do sujeito e que esteja voltada para a espiritualidade independente de crenças pontuais. Destaca-se, também, a abertura para a participação dos religiosos na equipe multidisciplinar, quando as questões relativas à religão forem relevantes no melhor entendimento do quadro patológico.

\section{- Comitê de Assistência Religiosa - CARE}

Da nova Ordem de Serviço resultaram algumas mudanças. Uma delas é a nova denominação da capelania, "que passou a ser Comitê de Assistência Religiosa - CARE - composto pelo mesmo Serviço Religioso Católico e Serviço Religioso Evangélico"98. A outra novidade advinda dessa nova Ordem de Serviço é a de que, afora os dois representantes titulares e o suplente de cada serviço, o Comitê

${ }^{97}$ Artigo 10 da Ordem de serviço $\mathrm{n}^{\circ}$ 05/95 do HCFMUSP.

98 Juntamente a esses, há a previsão da criação de um outro Serviço Religioso, considerada necessária pelos membros do CARE (Disponível em: <http://www.hcnet.usp.br/adm/care> Acesso em: 12/03/08). 
passaria a contar com um representante da Superintendência. Outra mudança é com relação aos leigos. Estes, que já desenvolviam trabalho voluntário no complexo HCFMUSP e eram nomeados Agentes de Pastoral ou colaboradores, passaram, então, a ser chamados de voluntários religiosos. A formação da coordenadoria administrativa do CARE, a partir dessas mudanças propostas pela nova Ordem de Serviço, dá-se do seguinte modo:

Será composta de no máximo 07 (sete) membros, sendo 02 (dois) representantes da igreja católica, 02 (dois) representantes das igrejas evangélicas; se necessário, de 02 (dois) representantes de outros credos e 01 (um) representante da Administração Superior do HCFMUSP. Acrescenta-se a essa coordenadoria a equipe dos voluntários religiosos (<http://www.hcnet.usp.br/adm/care. Acesso em: 12/03/08, destaque nosso).

Por fim, o objetivo do CARE, segundo seus fundadores, é "prestar assistência religiosa no Complexo HCFMUSP constituindo-se para o exercício do conjunto das ações voltadas à boa prática dos credos e cultos, em prol dos pacientes, familiares e servidores, assegurando a autonomia de cada um" (Disponível em: <http://www.hcnet.usp.br/adm/care> Acesso em: 12/03/08). Assim, a assistência religiosa é encarada como um instrumento de apoio, que deve considerar, antes de qualquer coisa, o respeito e a preservação da vontade daqueles que são atendidos.

\section{- Sobre o serviço de capelania atual}

Algumas regras devem ser seguidas sob pena de se perder o direito de fazer parte da equipe do serviço religioso ou até mesmo de ter o acesso ao hospital impedido, a principal delas é não fazer proselitismo: "Um dos itens dentro do comitê é justamente que não se faça propaganda ou não se toque na religião sua para o paciente se ele assim não quiser. Então você não tem que ir lá falar da sua religião, mas prestar uma assistência espiritual, uma coisa diferente" (M13) $)^{99}$. Portanto, é

\footnotetext{
${ }^{99}$ Médico entrevistado.
} 
primordial estar atento às regras relativas ao caráter não conversionista das religiões no interior do hospital.

A ideia que normalmente se tem quanto ao papel do capelão é equivocada. O assistente religioso é visto como alguém que realiza um trabalho para quem está prestes a morrer (AR1): “Muitos falam: 'Você veio ver alguém grave aqui?' Muitos ainda, principalmente os novatos que não me conhecem, acham que o padre está aqui pra atender paciente que vai morrer". Segundo AR1, essa situação relaciona-se com outra que é a questão da ausência - "ausência faz com que você não exista" (AR1) - dos religiosos no hospital: "Isso a Igreja tem culpa porque não está presente direto no hospital". A minguada presença das autoridades religiosas (padres, pastores) junto aos pacientes faz com que se tenha a impressão que a sua atuação esteja estritamente relacionada à questão de ritos, bênçãos.

As autoridades religiosas já foram convidadas a participar das reuniões clínicas, o que talvez fosse uma forma de fazer seu trabalho mais conhecido entre os profissionais, evitando uma visão equivocada. Entretanto, elas confessam não possuir tempo disponível. Admitem que falta de convite e abertura para participação não é o problema (AR1), os empecilhos relacionam-se à própria precariedade de condições no que concerne ao montante de profissionais não suficiente para dar conta de um um trabalho tão grande.

Às vezes é possível perceber uma idealização (e parece ficar nisso apenas) do que deveria ser a assistência religiosa, isso ocorre com respeito à projeção em relação ao modelo de capelania dos $E_{U} A^{100}$, que é tomado como parâmetro, como protótipo do que deveria ser posto em prática no Brasil. Tal modelo "não vê o religioso como sacramento", além do que para ser capelão não necessariamente precisa ser padre ou pastor (AR1).

[Nos EUA] eles são assim: "Você quer ser capelã? Está bom. Você vai fazer o curso, vai se preparar". E aqui tem muito aquilo de: "Não, se o cara quiser fazer...". Depois se enrola todo quando tem que se defrontar. [...] Para ser capelão você tem que fazer 1600 horas de curso, teórico e prático. Não vê o religioso como sacramento. Nós temos muito isso ainda. É o sacramento, é a oração, é a bênção, são os rituais. Eles [EUA] saíram um pouco disso já. (AR1).

${ }^{100}$ Como ver-se-á adiante, semelhante comparação é feita por alguns psiquiatras que, por sua vez, fazem reverência ao modelo de psiquiatria do EUA (no que concerne à importância dada às questões espirituais). 
Nós temos um curso aqui dentro de uma medida um pouco mais limitada. Eu fiz com o padre Léo logo que ele chegou dos EUA e ajudou muito, bastante. Mas de uma maneira intensa e extensa como há [nos EUA] não tem. [...] Pela experiência de outros [lugares] que eu conheço, aqui no Hospital das Clínicas, está muito longe de ser o que é nos hospitais dos EUA, por exemplo. Lá o capelão faz parte da equipe multiprofissional mesmo. Ele é ouvido/consultado. (AR3).

Ocorre também que a realização de cursos de formação de capelães acaba sendo prejudicada ou não incentivada por falta de apoio da instituição hospitalar que não facilita ações básicas como suporte material (a confecção de crachás, por exemplo). Assim, o que poderia deixar de ser uma idealização e passar a ser colocado em prática não acontece. As autoridades religiosas mostram-se dispostas a mudar o perfil de capelania, mas para isso necessitam da ajuda da instituição hospitalar, ajuda esta, que segundo acreditam, deveria acontecer com mais empenho - "A superintendência deveria entender assim: 'É o curso para formar capelães. Arruma tudo para eles com rapidez porque isso é essencial para o hospital'. Mas não. Não tem essa coisa”. (AR3). Assim, a responsabilidade pela deficiência no modelo de capelania recai, em parte, sobre as autoridades do hospital.

\subsubsection{Os informantes da pesquisa}

Os sujeitos analisados neste estudo são os especialistas de saúde mental (psiquiatras), os especialistas religiosos ${ }^{101}$ que atuam junto ao IPQ do HCFMUSP, bem como os pacientes (internados nas enfermarias). Aqui será focalizado também o Núcleo de Estudos de Problemas Espirituais e Religiosos (NEPER), atualmente denominado Programa de Saúde, Espiritualidade e Religiosidade (ProSER) ${ }^{102}$, ligado ao IPQ.

\footnotetext{
${ }^{101}$ Como já foi comentado neste trabalho, existem os serviços religiosos católico e evangélico, os quais compõem a capelania hospitalar do HCFMUSP, atualmente designada por CARE (Comitê de Assistência Religiosa).

102 Depois de uma pausa de quase dois anos, o NEPER foi retomado com algumas mudanças sob o nome de ProSER.
} 


\subsection{METODOLOGIA OPERACIONAL}

\subsubsection{As possíveis relações}

Existem dois tipos de relação possíveis de serem analisadas neste estudo. De um lado, a relação estabelecida entre especialistas ${ }^{103}$ da religião (ministros religiosos) e especialistas da saúde mental (psiquiatras). De outro lado, a relação desses dois tipos de especialista com os leigos que aqui, no caso, são os pacientes (leigos em relação tanto ao saber religioso quanto ao saber médico). Neste último caso, observar, no que diz respeito às crenças e atitudes religiosas dos pacientes, como os agentes religiosos e os médicos posicionam-se. Por fim, investigar como é a convivência - apesar das diferenças existentes entre o serviço religioso católico e o serviço religioso evangélico -, qual o tipo de relação esses especialistas religiosos travam entre si.

\subsubsection{Hipótese}

A hipótese levantada é de que, ao estabelecerem pontes de contato, os campos psiquiátrico e religioso tornam-se vulneráveis, podendo assim colocar em risco o seu desenvolvimento e a sua legalidade enquanto áreas de atuação autônomas.

Ao se observar o diálogo que é instaurado entre esses dois campos mediante os relatos dos depoentes de ambas as partes -, é possível perceber que, na relação entre eles, tem ocorrido uma influência recíproca, a qual pode expandir ou recuar conforme a dinâmica de cada campo. Porém, existem diferenças que não podem ser desprezadas. Como já fora dito em outra parte deste texto, enquanto a religião é movida pela moral, "o mercado dos bens científicos tem suas leis, que

${ }^{103}$ Na perspectiva de Bourdieu (1999, p. 39, aspas do autor), os especialistas seriam aqueles agentes reconhecidos como tendo a exclusividade sobre a competência necessária "à produção ou à reprodução de um 'corpus' deliberadamente organizado de conhecimentos secretos". 
nada têm a ver com a moral" (BOURDIEU, 1983a, p. 133). Além disso, vale a pena frisar: os produtores de um determinado campo só reconhecem como clientes seus próprios concorrentes, o que faz com que o valor de um produto só seja reconhecido por outro produtor do mesmo campo.

Tomando como ponto de partida a afirmação de Bourdieu (1983a) de que "aquele que faz apelo a uma autoridade exterior ao campo só pode atrair sobre si o descrédito", é possível que os diferentes campos (religioso e médico) estejam comprometendo o seu bom funcionamento, a partir do momento em que procuram valer-se de uma intimidade maior entre si. Desse modo, a intenção é verificar, primeiramente, se, e até que ponto, essas suspeitas são verdadeiras.

Num segundo momento, apesar das diferenças existentes na capelania (entre o serviço religioso católico e o serviço religioso evangélico), interessa compreender de que maneira se dá a convivência, qual tipo de relação os especialistas religiosos estabelecem entre si.

O discurso religioso elimina, de antemão, a presença de crenças não cristãs no hospital. O representante católico afirma que o serviço religioso do HCFMUSP possui caráter ecumênico e, por isso, tem de respeitar as crenças das pessoas: "A nossa filosofia é propor e não impor" (AR1). Mas, ao mesmo tempo, deixa claro que o ecumenismo do qual está falando restringe-se "às igrejas cristãs tradicionais", dentro das quais pode haver variações ${ }^{104}$. O contrário, para ele, é a reunião de várias crenças, que não se trata de ecumenismo, mas sim diálogo inter-religioso.

Espíritas negam o princípio fundamental do cristianismo, que é a ressurreição de Jesus. O serviço religioso é ecumênico, mas não é inter-religioso, por isso que não colocamos o espiritismo aqui dentro. É uma determinação da Ordem de Serviço. Devemos poupar o paciente ${ }^{105}$, se você começa a colocar diversas crenças aqui dentro, você começa a fazer uma confusão na cabeça do paciente ${ }^{106}$. (AR1).

\footnotetext{
104 Esse é um conceito teológico de ecumenismo. Entretanto, para além dessa definição, o ecumenismo não se relaciona a apenas uma crença de mesma linha teológica, ao contrário, qualquer religião pode manter uma interlocução, desde que seja considerada legítima. Ou seja, o que exclui o espiritismo não é o caráter cristão ou não cristão, mas sim o fato de não ser tido como legítimo pelas religiões que compõem o serviço religioso.

105 No entanto, como ver-se-á em momento oportuno, os pacientes queixam-se de falta de opções religiosas, mostram-se descontentes com uma proposta religiosa única.

106 Numa segunda conversa com o entrevistado, após o projeto haver sido aprovado pela Comissão de Ética do HCFMUSP, ocorre uma inflexão no discurso, o qual se torna mais maleável. Isso é compreensível, já que um campo é um espaço onde existem muitas contradições e também muitas pressões.
} 
Por meio desse discurso é possível perceber que os conflitos internos ao campo religioso fazem-se notar e não são ocultados, ainda que à frente desses atritos empunhe-se a bandeira do ecumenismo. No HCFMUSP, que é um hospital público, não confessional, o fato de haver ditames colocados pelo governo (superior de todos ali) orientando a se fazer um trabalho em comum - "a gente tem que obedecer necessariamente às normas do governo que nos manda trabalhar de uma maneira ecumênica" (AR3) - não impede a manifestação de conflitos. Desse modo, AR3 afirma: "Não é porque o governo nos manda trabalhar de uma maneira ecumênica que as coisas são pacíficas" (AR3). Ou seja, ainda que de forma discreta, o conflito acontece, em oposição às recomendações da hierarquia hospitalar.

Pode-se, tomando como base a afirmação acima, pensar a superintendência do HCFMUSP - representante do governo ali dentro - como a instância que controla a entrada e a distribuição de bens simbólicos no hospital, na medida em que é ela quem decide, a princípio, que religiões podem e não podem atuar ali dentro. Assim, é por ela que qualquer ministro religioso tem de passar para obter a permissão para realizar o seu trabalho.

Por exemplo, a gente recebe muitos pedidos de pessoas, já recebi de espíritas, da Seicho-No-le. O que fazemos nesse caso: normalmente, eles vão à superintendência e a superintendência nos encaminha $^{107}$. Aqui, mesmo sendo um hospital público, se eles insistirem realmente em fazer trabalho, o hospital vai falar: 'não, nós já temos um serviço religioso organizado'. (AR1).

Finalmente, no que diz respeito às crenças e atitudes religiosas dos pacientes, investigar-se-á como os agentes religiosos, de um lado, e os psiquiatras, de outro, posicionam-se: se há o cuidado em respeitar as crenças, os valores que o paciente traz consigo, levando em consideração que, no momento em que ele entra no hospital, traz consigo sua própria cultura. Isso quer dizer que suas crenças, atitudes, valores e relações sociais, o acompanham sempre e em qualquer momento da vida (GOFFMAN, 2005).

\footnotetext{
${ }^{107}$ Nota-se que a decisão final fica a cargo dos ministros religiosos. Isso não exclui, no entanto, o fato de a superintendência ser a primeira instância que define a entrada de religiões.
} 
Os ministros das duas capelanias colocam claramente o seu propósito enquanto religiosos que realizam um trabalho junto aos pacientes. Deve prevalecer, no ponto de vista de ambos, uma relação de respeito, em primeiro lugar, aos valores que o paciente traz consigo, sem o caráter de evangelização ${ }^{108}$, mas de "consolo", "de promoção do indivíduo na situação em que ele se encontra, de ruptura com a normalidade dele" (AR3). A finalidade última do trabalho religioso, nesse sentido, seria de "fazer com que o paciente resgate, sobretudo, os valores internos, interiores, subjetivos que ele tem e possa com esse resgate superar a sua situação de doença, de dor, de ruptura..." (AR3). A religião não deve ser vista como uma forma de "barganha" com o paciente, o que significaria claramente um desrespeito aos seus valores (AR3). Tendo em vista o caráter ecumênico do serviço religioso como lembra um dos religiosos, essa "é a regra do próprio hospital" (AR1) -, subentende-se que deva haver o respeito pela crença de cada um: "Você não deve tirar nada do que a pessoa acredita ou tentar impor alguma coisa pra pessoa" (AR1).

Se existe uma luta simbólica - procurar-se-á verificar em que medida isso acontece - no interior do espaço hospitalar, ela pode ocorrer tanto entre os religiosos de diferentes denominações quanto entre estes e os médicos. Pode tratarse de um campo de lutas por legitimidades e reconhecimentos entre aqueles que tradicionalmente detêm, de um lado, o monopólio do corpo (os médicos) e, de outro lado, aqueles que detêm o monopólio da alma (os religiosos). Nessa dicotomia, cada campo desempenha um papel fixo: assim como a bênção deve ser realizada pelo padre ou pastor, a cura deve ser posta em prática pelo médico ou psiquiatra, donos do discurso eloquente (OLIVEIRA, 1985, p. 85).

\footnotetext{
${ }^{108}$ Em momento oportuno, no capítulo 6, será possível perceber até que ponto isso é respeitado pelos religiosos.
} 


\subsubsection{Instrumental e procedimentos}

A população estudada é constituída por ministros religiosos ${ }^{109}$, psiquiatras ${ }^{110}$ e pacientes que frequentam o IPQ do HCFMUSP. Todos eles de qualquer sexo, idade, estado civil e nível socioeconômico.

Foram entrevistados 71 (setenta e um) informantes no total, entre psiquiatras, ministros religiosos, voluntários religiosos e pacientes que preenchiam os critérios estabelecidos. A divisão deu-se da seguinte maneira: 27 (vinte e sete) psiquiatras, 17 (dezessete) pacientes, 11 (onze) enfermeiros, 13 (treze) voluntários religiosos e 3 (três) ministros religiosos. A quantidade de entrevistas variou conforme a necessidade de explanação das questões. Na medida em que se esgotava o que era necessário investigar, as entrevistas eram finalizadas.

Para a avaliação das relações entre médicos-psiquiatras, ministros religiosos e pacientes ${ }^{111}$ foram usadas entrevistas semiestruturadas e gravadas. $O$ roteiro de questões foi confeccionado pela própria pesquisadora, que se ateve a questões que, de alguma forma, propiciasssem o entendimento das relações entre os agentes.

Aos pacientes, psiquiatras, enfermeiros e religiosos (ministros e voluntários) que concordaram em participar da pesquisa foram passadas todas as informações numa primeira conversa. Todos os sujeitos ficaram cientes de que deveriam responder a um conjunto de questões, o que ocorreria uma única vez. Nessa

\footnotetext{
${ }^{109}$ Apesar de atuarem no Instituto Central apenas (não tendo uma ação direta e constante no IPQ, poucas vezes por lá passaram), os voluntários religiosos foram entrevistados para que se pudesse captar o estilo de serviço religioso que é posto em prática pelos não especialistas no hospital. Ainda que os voluntários religiosos tenham atuação esporádica no IPQ, entrevistá-los foi importante para, de um lado, avaliar o tipo de assistência religiosa que vem sendo oferecida no HCFMUSP e, de outro lado, verificar se, a partir desse modelo de assistência, os agentes encontram-se em condições (caso for necessário) de prestar assistência religiosa junto a essa modalidade de pacientes (se estão preparados para isso, qual a visão que2 possuem da "patologia mental"). É fundamental fazer esse levantamento, visto que, futuramente, eles poderão prestar assistência religiosa no IPQ (posteriormente falar-se-á sobre a função do ProSER enquanto programa de treinamento para esta finalidade).

110 A princípio a ideia era entrevistar psiquiatras apenas, entretanto, percebeu-se que seria interessante saber o que os enfermeiros tinham a dizer, pois estes mantinham uma presença constante no hospital com atuação bem próxima ao paciente (maior até mesmo que a dos psiquiatras).

${ }_{111}$ A avaliação da relação estabelecida pelos psiquiatras e religiosos pôde ser realizada respectivamente por intermédio do modo como os psiquiatras lidam com a questão da religiosidade junto aos pacientes, e o modo como os ministros religiosos lidam com as prescrições médicas e com os diagnósticos dados aos pacientes.
} 
entrevista procurou-se abordar todas as questões necessárias ao desenvolvimento da pesquisa.

Para a realização das entrevistas, todos os participantes da pesquisa assinaram o "Termo de consentimento livre e esclarecido" (exigido pela Comissão de Ética em pesquisa), do qual foi fornecida uma cópia a cada um dos entrevistados. Dessa maneira, todos tiveram a possibilidade de tirar suas dúvidas a qualquer momento sobre o projeto (pedir informações sobre os procedimentos, os riscos e os benefícios da pesquisa).

\subsubsection{Critérios de seleção dos informantes}

Qualquer paciente internado no IPQ, independente do setor e do tipo de patologia que estivesse tratando, e em condições de responder à entrevista, pôde ser incluído entre os informantes.

O critério de inclusão foi 1) Em relação aos pacientes: estar internado recebendo tratamento no IPQ; 2) Em relação aos psiquiatras e enfermeiros: serem atuantes no IPQ; 3) Em relação aos ministros religiosos e voluntários religiosos: serem atuantes no IPQ. O critério de exclusão foi: pacientes com uso intenso de medicação e que, porventura, não estivessem em condições de conceder uma entrevista.

O primeiro critério foi definido pela pesquisadora, tomando como base a necessidade da presença efetiva no hospital de todos os agentes para que fosse possível avaliar se existia algum tipo de convivência, afinidade ou conflito. Já o segundo foi definido à medida que era possível observar a dificuldade que alguns pacientes manifestavam em manter um diálogo sequenciado devido ao quadro atual de sua patologia. Por isso, o critério de escolha foi os que estavam mais acessíveis no momento da entrevista tanto do ponto de vista da disposição quanto do nível de lucidez $^{112}$. Para obter esse tipo de informação contou-se com a colaboração dos

112 É arbitrária a definição de "doença mental". Entretanto, a partir do momento em que o indivíduo encontra-se recluso na enfermaria, acredita-se que não será o pesquisador que estará apto a julgar quem é mais ou menos capaz de interagir. 
enfermeiros que eram normalmente os mais indicados a possuírem esses detalhes, pois acompanhavam dia a dia o desenvolvimento do paciente, conheciam bem as suas limitações naquele momento. A partir disso houve uma triagem no sentido de que esses profissionais indicavam aqueles que estavam em melhores condições para conversar.

As enfermarias que compõem atualmente o IPQ comportam 82 leitos no total $^{113}$. Elas estão divididas em função das diferentes patologias, como é possível perceber no quadro a seguir. As entrevistas concentraram-se nas seguintes enfermarias: Mista; Geriatria; Comportamento alimentar ${ }^{114}$.

\begin{tabular}{|c|c|c|c|}
\hline $\begin{array}{l}\text { UNIDADE } \\
\text { SIGLA }\end{array}$ & UNIDADE & $\begin{array}{l}\mathbf{N}^{\circ} \mathrm{DE} \\
\text { LEITOS }\end{array}$ & DIAGNÓSTICO \\
\hline EMIS & ENFERMARIA MISTA & 12 & $\begin{array}{l}\text { Esquizofrenia, Transtorno Bipolar, } \\
\text { Quadros Psicóticos agudos. }\end{array}$ \\
\hline EAND & $\begin{array}{l}\text { ENFERMARIA ANSIEDADE E } \\
\text { DEPRESSÃO }\end{array}$ & 14 & $\begin{array}{l}\text { Depressão, Transtorno Obsessivo } \\
\text { compulsivo, Transtornos de Ansiedade, } \\
\text { Transtorno do Pânico. }\end{array}$ \\
\hline ECAL & $\begin{array}{l}\text { ENFERMARIA DE } \\
\text { COMPORTAMENTO } \\
\text { ALIMENTAR }\end{array}$ & 10 & $\begin{array}{l}\text { Transtorno Alimentar (Anorexia e } \\
\text { Bulimia). }\end{array}$ \\
\hline EGRT & ENFERMARIA DE GERIATRIA & 12 & $\begin{array}{l}\text { Transtorno Bipolar, Demência, } \\
\text { Alzheimer, Transtornos Depressivos, } \\
\text { Ideação Suicida. }\end{array}$ \\
\hline EHDI & $\begin{array}{l}\text { ENFERMARIA INFANTIL E } \\
\text { ADOLESCENTES }\end{array}$ & 9 & $\begin{array}{l}\text { Transtorno Alimentar (Anorexia e } \\
\text { Bulimia) e outros transtornos } \\
\text { psiquiátricos. }\end{array}$ \\
\hline EDQ & $\begin{array}{l}\text { ENFERMARIA DEPENDÊNCIA } \\
\text { QUÍMICA }\end{array}$ & 12 & $\begin{array}{l}\text { Dependência de Múltiplas Drogas, } \\
\text { Alcoolismo, Comportamento Impulsivo. }\end{array}$ \\
\hline EMET & ENFERMARIA METABÓLICA & 13 & $\begin{array}{l}\text { Depressão, Quadro de mania, } \\
\text { Esquizofrenia, Transtorno Alimentar, } \\
\text { Demência, quadros clínicos e } \\
\text { neurológicos. }\end{array}$ \\
\hline
\end{tabular}

Quadro 1 - Descrição das enfermarias

Além do mais, o contato e a escolha dos informantes (psiquiatras, enfermeiros, pacientes, ministros religiosos, voluntários religiosos) deram-se a partir da apresentação da pesquisa ${ }^{115}$ e o convite para que participassem. As entrevistas

\footnotetext{
113 Divisão de enfermagem do IPQ [mensagem pessoal]. Mensagem recebida por <enfermagem.ipq@hcnet.usp.br> em 15 jan. 2010.

${ }^{114}$ A enfermaria Mista foi a de mais difícil acesso pelos quadros mais graves, pelos horários rígidos (horários para medicamentos, para atividades terapêuticas). Já na enfermaria do comportamento alimentar, foi possível um acesso maior aos pacientes, o que fez com que a maior parte das entrevistas fosse realizada nesse setor.

${ }^{115}$ Com relação aos psiquiatras, a apresentação aconteceu com a ajuda do pesquisador responsável pela pesquisa junto ao Comitê de Ética e junto ao IPQ. Aproveitando um evento que acontecia no Instituto, onde estavam presentes vários psiquiatras (entre assistentes, residentes, colaboradores), a
} 
com os psiquiatras ocorreram muito em função de sua boa vontade, aceitação e disponibilidade. Tudo dependeu muito da influência de um médico mais antigo na casa e do respeito que os demais tinham por ele, além, é claro, da referida boa vontade. Eles sempre aparentavam segurança no que falavam. Já os enfermeiros apresentavam-se um pouco resistentes, sempre se mostrando muito ocupados e sem tempo ${ }^{116}$. Aparentavam desconfiança, na maior parte dos casos, normalmente ponderando bem o que falavam.

A dificuldade de realizar entrevistas não é uma constatação que cause estranheza, sabe-se muito bem dos percalços por quais passa um pesquisador. $A$ resistência dos entrevistados pode ocorrer em função de motivos diversos: no caso dos enfermeiros, o receio de falarem algo que pudesse ser usado contra eles, que fizesse com que fossem punidos ou até demitidos; no caso dos pacientes, o temor de perder o direito ao tratamento ou de serem punidos de alguma forma. Neste último caso, a demonstração do referido temor deu-se mediante a desconfiança e as respostas pontuais, as quais marcaram em grande medida a realização das entrevistas.

pesquisadora foi apresentada a estes profissionais e foi possível dar início ao contato necessário para posterior realização das entrevistas. Sem essa apresentação e sem o apoio do referido professor/pesquisador, não teria sido possível esse contato, mesmo levando em consideração a aprovação do projeto de pesquisa pelo Comitê de Ética do HCFMUSP. Outros momentos foram utilizados para a apresentação da pesquisa, por exemplo, as reuniões clínicas, as quais eram acompanhadas por muitos psiquiatras residentes. Com relação aos enfermeiros, algo semelhante aconteceu. A pesquisa foi apresentada para a enfermeira-chefe e esta, por sua vez, fez com que a pesquisadora fosse conhecida e recebida pelas enfermeiras responsáveis por cada enfermaria. Estas últimas convidaram e estimularam todos os enfermeiros e auxiliares de enfermagem a participarem da pesquisa. Em relação aos religiosos, houve apresentação da pesquisa aos voluntários, os quais foram encorajados pelas autoridades religiosas a participarem.

${ }^{116}$ Apesar de ser mais fácil encontrar, nas enfermarias, os enfermeiros que os psiquiatras - estes tinham horários determinados para ver os pacientes e tudo acontecia muito rapidamente. 


\section{PARTE II - CAMPO PSIQUIÁTRICO E CAMPO}

\section{RELIGIOSO: MORFOLOGIAS ${ }^{117}$}

117 A partir de agora - momento de utilização recorrente das entrevistas -, os trechos referentes às falas dos informantes aparecerão sempre com uma sigla que designa quem fala. Os psiquiatras são representados pela sigla $\mathbf{M}$ (M de médicos para não se confundirem com o $\mathrm{P}$ de pacientes), os enfermeiros pela sigla $\mathbf{E}$, os pacientes pela sigla $\mathbf{P}$, os voluntários religiosos pela sigla VR e os padres e pastores pela sigla AR (autoridade religiosa). Todos os destaques nos trechos das entrevistas foram utilizados com o objetivo de ressaltar aspectos para os quais se pretende chamar a atenção dos leitores. Não se trata, portanto, de ênfase dada pelos próprios depoentes. Outra coisa importante a se esclarecer antecipadamente é que, somente alguns trechos - dentre os inúmeros que poderiam ser tomados como paradigmáticos em relação a cada assunto - serão apresentados. Infelizmente, ainda que sejam interessantíssimos, não será possível, por questões de ordem prática, tê-los todos aqui. 


\title{
3 MODELO PSIQUIÁTRICO ATUAL
}

\subsection{POSICIONAMENTO DO PSIQUIATRA NO CAMPO PSIQUIÁTRICO}

\begin{abstract}
Desde que há um espaço social, há luta, há luta de dominação, há um pólo dominante, há um pólo dominado, e desde este momento há verdades antagônicas. O que quer que se faça a esse respeito, a verdade é antagônica. Se há uma verdade, é que a verdade é um objeto de luta. (Bourdieu, Questões de Sociologia).
\end{abstract}

$\mathrm{Na}$ tentativa de tornar conhecidos os posicionamentos dos psiquiatras no campo psiquiátrico, pretende-se aqui desenhar as características essenciais que definem a postura de cada um. Três formas de posicionamento distintas podem ser consideradas no interior do campo psiquiatra, são eles: o mono-posicionado (psiquiatra "puro"), o bi-posicionado (psiquiatra "espiritualista") e o "neutro"/ambíguo. Como estratégia de definição desses grupos foram eleitas algumas opiniões dos informantes recorrentes nas entrevistas.

O mono-posicionado possui características que o aproxima mais dos ideais de pureza do campo ao qual pertence, ele está inclinado a uma postura mais ortodoxa, na qual vigora a defesa dos princípios de estruturação do campo. Já o biposicionado apresenta-se como o contestador da ordem vigente e busca por uma abordagem que, para além do rigor dos conceitos, dê voz às necessidades religiosas/espirituais. Por último, o "neutro"/ambíguo pode ser considerado o sujeito que aceita a presença religiosa, que percebe importância no fator religião para o paciente; entretanto, não é engajado nessa problemática a ponto de debruçar-se especificamente nela, seja no que condiz ao tratamento junto ao paciente, seja no que se refere a pesquisas nessa área ou à participação em núcleos de discussões a esse respeito ${ }^{118}$.

\footnotetext{
${ }^{118}$ Quanto ao posicionamento dos médicos, uma enfermeira afirma, ipsis litteris, o seguinte: "Eu acho que os que acreditam apoiam, até gostam, mas os que não acreditam preferem ficar neutros".
} 
A luta, ainda que não declarada no campo, pode ser visualizada por intermédio do engajamento nos subcampos "puro" e "espiritualista" em torno da definição dos objetivos reais da psiquiatria. Os dois posicionamentos podem ser encarados mediante o que descreve Bourdieu (1996, p. 66) em relação ao campo artístico relativamente à oposição vanguarda consagrada/nova vanguarda. Assim, no interior do IPQ-USP haveria a nova vanguarda (os psiquiatras bi-posicionados), que surge com proposta diferenciada, com estratégias de transformação do campo.

O quadro a seguir apresenta mais detalhadamente quais os informantes compõem os diferentes posicionamentos.

\begin{tabular}{|l|l|l|l|l|l|}
\hline Mono-posicionado & \multicolumn{3}{|l|}{ Bi-posicionado } & \multicolumn{2}{l|}{ Neutro/Ambíguo } \\
\hline Psiquiatras & Enfermeiros & Psiquiatras & Enfermeiros & Psiquiatras & Enfermeiros \\
\hline M10 & & M1 & E3 & M2 & E1 \\
\hline M15 & M7 & E11 & M3 & E2 \\
\hline & M13 & & M4 & E4 \\
\hline & M22 & & M5 & E5 \\
\hline & M23 & & M6 & E6 \\
\hline & M24 & & M8 & E7 \\
\hline & & M27 & & M9 & E8 \\
\hline & & & M11 & E9 \\
\hline & & & M12 & E10 \\
\hline & & & & M14 & \\
\hline & & & & M16 & \\
\hline & & & & M17 & \\
\hline & & & & M19 & \\
\hline & & & & M20 & \\
\hline & & & & M21 & \\
\hline & & & & M26 & \\
\hline
\end{tabular}

\section{Quadro 2 - Posicionamento no campo psiquiátrico}

A seguir é possível perscrutar quais características compõem o perfil de cada um dos posicionamentos. 


\subsubsection{Mono-posicionado (psiquiatra "puro")}

País laico, universidade laica, hospital laico. (Psiquiatra entrevistado).

São 2 (dois) ${ }^{119}$ os entrevistados mono-posicionados ou "puros", assim definidos por aparentemente aproximarem-se das características do que seria considerado um campo psiquiátrico genuíno, sem qualquer tipo de interferência externa ${ }^{120}$. O que os retrata como tal pode ser descrito por intermédio dos seguintes posicionamentos:

- Religião não é um dado importante ${ }^{121}$

- O profissional deve delimitar-se à parte médica ${ }^{122}$

Quando inquirido sobre a presença religiosa nos hospitais, um dos entrevistados foi contundente: "Eu, pessoalmente, não gosto. Eu acho que a universidade é laica e o hospital é da universidade, não tinha nada que ter religioso aqui, mas nada contra ter um serviço de assistência a pedido do paciente. [...] Estado laico, universidade laica" (M10). O atendimento religioso só deveria acontecer em casos específicos, não de uma forma geral e sempre (M10), apenas a pedido do paciente (M10). Essa visão leva em conta o fato de a religião, para o

\footnotetext{
119 Embora este estudo não seja quantitativo, a ocasionalidade da inclusão dos psiquiatras informantes faz sobressair o caráter minoritário dos mono-posicionados. Segundo esclarece Minayo (2007, p. 192), "o investigador que trabalha com abordagem qualitativa nunca pode esquecer-se de que não estuda um somatório de depoimentos. Isso significa que a práxis compreensiva pode até utilizar critérios numéricos (número de entrevistas), mas não necessariamente será este o definidor de relevâncias, muitas vezes esclarecidas pela fala de apenas um ou de poucos interlocutores".

${ }^{120}$ É importante alertar que, como será notado ao longo do texto, os informantes M10 e M15 (os únicos mono-posicionados no campo psiquiátrico) fazem afirmações que trazem confusão quanto ao seu posicionamento purista/ortodoxo no campo. É que os dois casos, apesar de contrários à presença religiosa no hospital, consideram alguns aspectos que podem ser positivos para o paciente no contato com a religião/religiosidade. Ainda assim, eles são os casos paradigmáticos de posicionamento que rechaça a assistência religiosa, seja por parte dos religiosos, seja por parte dos psiquiatras.

${ }^{121}$ Ideias que circundam esse posicionamento: Falar em religião estritamente a pedido do paciente (M10); Não há demanda quanto à religião por parte dos pacientes (M15); Não valoriza religião como um dado importante (M15).

122 Ideias que circundam esse posicionamento: Contra cursos na psiquiatria, cada um busca informações por si e fora (M15); Não emitir juízos de valor no hospital (M15), País laico, universidade laica, hospital laico (M10);Trabalho da psiquiatria deve ser delimitado à parte médica (M15).
} 
paciente psiquiátrico, ser uma forma de pressão a mais (M10), na qual questões como culpa, perdão sempre afloram, o que não seria benéfico.

Considera-se que em outras especialidades isso até poderia ser possível, mas não no caso da psiquiatria (M15). Além de não conseguir ver essa demanda por parte dos pacientes (M15), tudo passa por uma questão pessoal (M15) de não crer, de nunca ter tido uma presença religiosa na sua vida (M15). O hospital, nessa perspectiva, não é visto como o locus para tal mobilização, tal presença, não é o lugar adequado para a oferta de um serviço religioso, principalmente o setor psiquiátrico, com o qual o depoente consegue perceber menos articulação ainda, menos interface. Assistência religiosa é considerada como algo que o paciente deve procurar fora do ambiente hospitalar, bem como o trabalho do psiquiatra deve restringir-se a questões médicas apenas (M15).

Como a questão pessoal tem peso, é possível que semelhante posicionamento reflita a crença do sujeito: "Eu nunca estimulo nem desestimulo. Eu sempre tenho uma posição tal e qual a minha crença, que é agnóstica. Praticamente eu não opino sobre isso e, se a pessoa acha que fez bem, eu falo: 'Bom, que bom que fez bem' e só me oponho quando a crença religiosa atrapalha o tratamento" (M15). Essa modalidade de profissional considera que questões extras devem ser pesquisadas ou buscadas pelo próprio profissional, não havendo necessidade de se oferecerem formações que abordem essa temática dentro dos cursos de psiquiatria (M15).

Esses casos apresentados são paradigmáticos da postura que se coloca contra a presença religiosa nos hospitais. Associadas a ela, outras formas de confrontamento são apresentadas por profissionais que fazem um balanço geral do posicionamento sobre religião no conjunto da psiquiatria. Outros psiquiatras que não se enquadram na categoria precedente consideram que entre os seus colegas de profissão normalmente os posicionamentos são de pessoas que: têm preconceito (M16), se acham donas da verdade $(\mathrm{M} 16)^{123}$, fazem comentários pejorativos (M21), têm resistência em tocar no assunto (M21), são radicais a ponto de achar que

${ }^{123}$ Ao comentar a possível falta de interesse dos médicos com relação a cursos sobre o tema saúde/espiritualidade que porventura fossem oferecidos na graduação, M16 afirma: "Tem gente que vai achar isso uma bobagem ou menos importante do que ficar no microscopiozinho vendo celulazinha" (M16). 
qualquer tipo de religião é uma forma de psicose (M24), tem a religião como um tabu (M24), são desinteressadas/distanciadas do tema religião (M22).

Essa percepção (colocada de forma crítica por psiquiatras bi-posicionados e neutros) com relação à comunidade psiquiátrica em geral pode ser reveladora de aspectos compartilhados por esses profissionais no que diz respeito à totalidade do campo psiquiátrico.

\subsubsection{Bi-posicionado (psiquiatra "espiritualista")}

São 7 (sete) psiquiatras e 2 (dois) enfermeiros bi-posicionados ou "espiritualistas". Tal atribuição está relacionada ao fato de abrirem espaço para questões que não apenas as relacionadas ao campo psiquiátrico, mas àquelas que têm interface com esse campo, por exemplo, as questões religiosas, espirituais. Eles são caracterizados mediante os seguintes posicionamentos:

- Religião é importante para o paciente ${ }^{124}$

- A favor de medicina com outras abordagens ${ }^{125}$.

A seguir alguns trechos considerados significativos para ilustrar o que se denomina psiquiatra bi-posicionado:

Montei um curso uma vez. Tem até hoje o curso, chama medicina além do corpo. O primeiro curso eu chamei o Lotufo, que foi falar de religião, acupuntura, essas medicinas que têm outras abordagens.

\footnotetext{
124 Ideias que circundam esse posicionamento: Médico que tem vivência religiosa consegue ver a importância da religião para o paciente (M7)/ Acha que deveria ter vários serviços religiosos (por exemplo, budista, espírita, maometano) lá dentro (M23)/ Deveria ter encontro multidisciplinar, onde religiosos participassem (M22)/ Psiquiatra deve ver o paciente em todos os ângulos (M22)/ Pacientes devem ser abordados do ponto de vista espiritual (M13)/ Ser humano precisa da parte religiosa (M23)/ Se perceber que o paciente é muito religioso, é interessante falar disso com ele, mesmo que ele não tenha falado diretamente (M24)/ Religião ajuda a lidar com a doença (E3)/ Quando o paciente é descrente é mais difícil o tratamento (M7)/ Tentar jogar um pouco de ideias espirituais, ou seja, incentivar uma vivência espiritual no paciente (M24)/ Religião está presente nos delírios, precisa ser ouvida (E11).

${ }^{125}$ Ideias que circundam esse posicionamento: A favor de medicinas com outras abordagens (M7)/ Fez curso de medicina além do corpo (M7, M24)/ Paciente pode estar com problema espiritual e não melhora com remédio (M24)/ Dá para conciliar espiritualidade e psiquiatria (M24)/ Não existe assunto tabu, se for interessante a gente conversa (M24).
} 
Umas experiências além do corpo [...]. Eu tenho uma visão mais abrangente. [...] Tem uma outra optativa que entrou esse ano, Dr. Sérgio Felipe, que ele faz no consultório dele. Ele leva os estudantes para conhecerem/tratar sobre espiritualidade, como abordar isso para entrevistar os pacientes. (M7).

É necessário fazer um link entre as pesquisas que estão acontecendo que impactam a espiritualidade e saúde das pessoas, para mostrar que isso não é uma questão só e exclusivamente de fé. É uma questão de ciência. [...] Eu acho que, não só o paciente psiquiátrico, todos os pacientes devem ser abordados do ponto de vista espiritual. Abordados de uma maneira científica também [...] Eu acho que deve partir do médico. O médico deve fazer parte, deve colher a história, anamnese espiritual de todo paciente. [...] Os pacientes que estão internados, eu falo sobre questões religiosas com eles. Oro com os pacientes ${ }^{126}$, se eles acharem conveniente. (M13).

O ser humano tem a vertente dele também espiritual e eu acho extremamente necessário. Todos nós, principalmente o psiquiatra, tem que ver o paciente em todos os ângulos: psicológicos, biológicos, sociais. O credo religioso faz parte. Então, eu acho fundamental. [...] Como eu sou psiquiatra mais da linha existencialista... o existencialismo trabalha com projetos. O que você é e o que você se projeta. E a religião é uma das que ajudam [...] Quando eu falo de religião para os pacientes [é em relação] aos aspectos formativos que toda a religião traz, não dos aspectos só de rituais. Os aspectos formativos eu acho extremamente importante. Eles fazem a gente rever o homem nesse universo de uma maneira até filosófica. Como falta muito hoje filosofia, a religião preenche isso. [...] Vai de médico para médico. Eu, como trabalho aqui formando residentes, os estimulo a terem essas conversas sobre religião. Eu não sei como eles são sucedidos porque nunca me trouxeram um retorno. (M22).

Se o indivíduo é bastante religioso e você percebeu isso na conversa, veio do paciente, não veio de você. Se eu conseguir sacar que o paciente é um pouco religioso é porque ele, de alguma maneira, está me transmitindo isso e aí eu acho interessante falar disso com ele. Mesmo que ele não tenha falado diretamente [...] Eu sou espírita. Então eu acredito em espiritismo, que existem algumas coisas que não são explicadas pela ciência, mas também eu acredito que o indivíduo, por exemplo, possa estar com algum problema talvez espiritual e ele não melhora com remédio. Se o paciente/pessoa melhora com remédio provavelmente é uma doença, sim. (M24).

${ }^{126}$ Este é o caso mais radical (dentre os bi-posiconados, embora se trate de médico de outra especialidade, mas que no momento da entrevista compunha o NEPER) de valorização da religião no tratamento: participação conjunta com o paciente em ritual religioso dentro do próprio tratamento. 


\subsection{3 “Neutro”/Ambíguo}

O que priva o doutor do pão?

a) a saúde, b) a morte.

Por isso, para viver, o médico mantém-nos

pairando entre ambas ${ }^{127}$. (Equilibrio, Eugen Roth).

São 18 (dezoito) psiquiatras e 9 (nove) enfermeiros "neutros"/ambíguos, desse modo conceituados por não se posicionarem declaradamente a favor da abordagem religiosa, mas não se oporem totalmente a ela, sempre fazendo ressalvas. São portadores de um discurso evasivo, o qual faz com que o seu estilo não seja normalmente claro a ponto de serem incluídos em um dos extremos mono-posicionado ou bi-posicionado. As características que os justificam nesse posicionamento podem ser apreciadas a seguir:

- É possível abordar a religiosidade desde que respeite as posições de cada um ${ }^{128}$

- Depende do momento ${ }^{129}$

- Religião pode ser uma ferramenta para compreender o doente ${ }^{130}$

- Somente se houver demanda ${ }^{131}$

- Faz parte da cultura ${ }^{132}$

\footnotetext{
${ }^{127}$ Texto original em alemão: Was bringt den Doktor um sein Brot? a) die Gesundheit, b) der Tod. Drum hält der Arzt, auf daß er lebe, Uns zwischen beiden in der Schwebe. (Gleichgewicht, Eugen Roth).

${ }^{128}$ Ideias que circundam esse posicionamento: Desde que respeite a posição de cada um (M21)/ Ver o ponto de vista do outro (M3)/ Respeitar (E2, E5, E6, E7, E8)/ Acha que se o profissional se aprofunda no assunto, se entende, ele acaba respeitando mais (E7).

${ }_{129}$ Ideias que circundam esse posicionamento: Depende do momento (M3)/ Em casos pontuais, depende do diagnóstico, da patologia, avaliar, não estimular delírio, se estiver de acordo com a parte clínica (M12, E2, E5, E6, E7, E9, E10)/ Perguntar apenas para investigar, não deve influenciar paciente/ Apenas para aliviar a angústia humana (M20)/ Com pessoas suicidas puxa-se esse assunto (M21, M19)/ Tem que ter preparo (E4)/ Tanto positivo quanto negativo (E4).

${ }_{30}$ Ideias que circundam esse posicionamento: Ver como a informação pode ajudar (M3)/ Ferramenta para compreender o doente (M2)/ Em prol do tratamento (M6, M21)/ Como mais uma ajuda, sem esquecer que o trabalho clínico vem em primeiro lugar (M6)/ Não ser dogmático colocando barreiras à religião (M14)/ Religião, fator protetor para a doença mental (M11)/ Paciente mais confortável com abordagem dupla (M9)/ Paciente com fé lida melhor com a doença (M8)/ Estar aberto, ter flexibilidade (E4)/ Conforto espiritual, ajuda (E4, E5, E10)/ Crença sem ser religião (E5).

31 Ideias que circundam esse posicionamento: Se o paciente trouxer a questão (M2, M12, M18, M21)/ Se houver demanda (M26)/ Respeitar (M14)/ Depende da necessidade do paciente (M25)/ Se o paciente aceitar (M19)/ Quando o paciente pede, não impor, não influenciar (E2, E6, E7, E8, E9, E10).

${ }_{132}$ Ideias que circundam esse posicionamento: Os diversos aspectos da vida do paciente (M14, M18) Paciente precisa de tudo aquilo que ele acredita para melhorar (M21)/ Faz parte de vida comunitária (M4, M11)/ Religião importante não se deve ignorar, mas utilizar como forma terapêutica (M16)/ Evitar
} 
Seguem alguns trechos mais elucidativos do posicionamento desses profissionais:

Eu acho que depende do momento e do caso. Acho que tem momentos que não é legal, que a pessoa tá muito mal, talvez não seja a hora legal, eu como médico, pensando, mas acho que na maioria dos momentos acho que seria muito legal. (M3).

Eu tento não me colocar em uma postura dogmática no sentido de não colocar barreiras. [...] Então eu acho que muito mais é buscar uma atitude mais conciliatória, mesmo [...] acaba que eu me coloco nessa situação: de não crer, mas ao mesmo tempo respeitar e, se existir alguma coisa, espero também ser salvo. (M14).

Eu sou a favor em termos. Eu acho que desde que seja algo para aliviar a angústia humana é evidente que eu sou a favor. Mas eu tenho visto pessoas menos preocupadas com a angústia humana e mais preocupadas com o comércio. (M20).

A religiosidade pode interferir sim. Tanto de forma positiva quanto de forma negativa. Acho que depende do foco, do contexto. (E4).

\subsubsection{Capital científico ${ }^{133}$}

Como foi possível perceber, os posicionamentos no campo psiquiátrico funcionam de maneira que há os que ocupam lugar: 1) em dois campos (os psiquiatras bi-posicionados ou "espiritualistas"), 2) em um campo (os psiquiatras mono-posicionados ou "puros"), 3) neutro (os psiquiatras que fazem uma síntese humana, tendo um posicionamento moderado e menos comprometedor $)^{134}$. Resta saber quem, de fato, detém capital mais alto nesse campo.

Bourdieu (como já foi abordado detalhadamente no capítulo 1 da parte I) afirma que em todo campo tem um jogo - com formas de capital, bens em jogo - e todos lutam porque há nele interesses (não necessariamente econômicos, pode

falar de coisas pessoais, manter certo distanciamento (M8, M14)/ Se a questão aparecer é porque é importante, então o médico precisa entender essa dimensão (M26)/ Faz parte da nossa cultura, da vida da pessoa (E9, E4).

${ }^{133}$ Aqui alguns bi-posicionados falam dos trabalhos científicos que vêm sendo publicados mostrando a importância de se pensar a interface ciência/religião. Procuram evidenciar que possuem o respaldo de um grupo de especialistas com lugar de destaque na comunidade científica dos EUA.

134 Estes destacam mais os aspectos culturais de um modo geral do que simplesmente os aspectos religiosos. Estratégia, quem sabe, para atuar livremente nos dois extremos. 
haver também interesses propriamente religiosos, científicos). O que produz campos diferentes é o fato de possuírem interesses próprios. Ao pensar nesses termos, tende-se a apresentar os fatos de uma forma um tanto quanto "materialista" no sentido de que o capital é muito importante. Entretanto, essa é uma discussão que não pode deixar de ser realizada em se tratando do mundo social, visto sob a perspectiva bourdieusiana pela qual se fez opção neste estudo.

Quando se fala da diferença de capital entre os psiquiatras ou entre estes e os religiosos, é possível fazer diferentes suposições ${ }^{135}$. Por exemplo, poder-se-ia cogitar a hipótese de que o psiquiatra mono-posicionado tem capital mais alto que o psiquiatra bi-posicionado, o qual - ainda que não sofra, claramente, preconceito poderá ter, no campo, uma posição baixa (com menor capital), denotada como "suspeita" no sentido de que indiretamente será sempre indagada se traz consigo um posicionamento mais científico do que religioso ${ }^{136}$ ou o contrário. Já quando se compara o psiquiatra (independente da sua posição) ao religioso, pode conjecturarse que o primeiro tem mais capital cultural certificado por diploma que o segundo ${ }^{137}$. Pode falar-se em posse de um saber secreto, um dom quando se compara o psiquiatra ao religioso, entretanto, existe uma diferença que se instaura como um abismo entre esses dois profissionais: a frequência à instituição escolar e a caução da cidadela científica. Estas conferem autoridade ao médico, o que não acontece com "a posse de um dom ou de uma graça particular por si só" (BOLTANSKI, 2004, p. 50), que não constituem "uma fonte de autoridade suficiente" (IBIDEM). Não são todos os religiosos - exceto as autoridades - que possuem diploma para atuarem, ao contrário dos médicos que obrigatoriamente necessitam possuir o certificado de nível superior.

A reflexão sobre as posições, consequentemente, coloca em pauta o espaço do NEPER/ProSER não apenas dentro do IPQ, mas também em relação à discussão de fora (por exemplo, em relação às universidades norte-americanas tão recorrentemente citadas pelos seus integrantes). Por ser o capital religioso mais baixo que o capital científico, os psiquiatras bi-posicionados valem-se (além de todo

${ }^{135}$ Obviamente, trata-se de hipóteses alternativas que, apesar de úteis à reflexão, não são os pilares deste trabalho.

${ }_{136}$ Levando-se em consideração a possibilidade real de que o profissional, ao defender uma psiquiatria sensível aos aspectos religiosos/espirituais, volte-se excessivamente para esses aspectos em detrimento dos aspectos científicos.

${ }^{137}$ No hospital, a detentora de poder é a medicina científica, não uma medicina espiritualista, e muito menos a religião e seus especialistas. 
o seu comprometimento com um trabalho sério de base científica) do lugar privilegiado, no caso os EUA, na busca por reconhecimento e respeito. Nessa direção, a autoridade desses profissionais estrangeiros - os quais, por sua vez, colocam em questão o propalado prejuízo do convívio entre medicina e religião (M13) - é utilizada com vistas à obtenção de aceitação pelos pares.

No começo não tinha nenhum grupo específico que nos inspirava. Mas, com o tempo, na medida em que nós fomos conhecendo... até porque eu não conhecia muito bem a literatura. Eu tinha interesse, mas não conhecia muito bem. Aí comecei a tomar contato com os vários grupos de pesquisa e dois grupos de pesquisa que, com o tempo começaram a me inspirar, foi o grupo do Harold koenig em Duke e o grupo do lan Steavenson, na Universidade da Virgínia, que é um grupo também de pesquisa bem diferente da Duke, mas que são abordagens que eu acho complementares. Que de um modo geral andam separadas, mas eu acho que são complementares. Isso foi a posteriori, não foi no começo essa inspiração [...] Ao longo do grupo começou a ter como referência que eram grupos, talvez os dois principais grupos, que mais produziam academicamente, publicavam, impactavam a comunidade científica nos seus respectivos campos. (M1).

Eu acho que o pessoal da Duke University, principalmente o Koenig, e o Larson, que antecedeu o Koenig lá na Duke, são grandes influenciadores. A Christina Puchalski, da Washington University, o Benson, da Harvard são pessoas que, realmente, influenciam não só o Brasil. Eles são os modernos que estão hoje, dos que estão aí atuando, porque eu acho que essas coisas sempre existiram. (M27).

O fato de fazer referência aos especialistas internacionais que tratam da questão não torna os psiquiatras bi-posicionados menos capazes ou com capital científico insuficiente para sustentar as suas escolhas. Isso mostra, no fundo, a necessidade que esses sujeitos - que estão por trás de um objeto considerado pelos seus pares como "duvidoso" ou de menor valor - têm de buscar apoio e sustentação em universidades e especialistas estrangeiros ${ }^{138}$ num país dominante econômica e militarmente sobre os demais como os EUA. A despeito de tal justificativa, semelhante mentalidade é analisada por Bourdieu (1983a, p. 130, aspas do autor) como sendo uma "filosofia ingênua da objetividade que inspira o recurso a

\footnotetext{
${ }^{138} \mathrm{O}$ que não significa que, no estrangeiro, esse objeto juntamente com os especialistas que a ele aderiram não tenham também menos valor. No entanto, mesmo ocupando uma posição inferior lá fora, aqui eles ocupam posição mais prestigiada frente ao conjunto dos psiquiatras (adeptos e não adeptos da questão espiritual). Tal situação pode ocorrer devido à dominação econômica e política (e, consequentemente, à valorização ou imposição de tudo que a ela esteja relacionado) exercida pelo referido país.
} 
'especialistas internacionais'”. Entretanto, é equivocado esse pensamento, pois a situação de observadores estrangeiros não os coloca "ao abrigo dos parti pris e das tomadas de posição num momento em que a economia das trocas ideológicas conhece tantas sociedades multinacionais" (destaque do autor). Ou seja, o fato de estarem distanciados, espacialmente falando, não os isenta de um comprometimento ideológico, para o qual não existem barreiras espaciais.

Inicialmente, o medo de resistência por parte dos profissionais da área atemorizou aqueles que davam os primeiros passos na direção de constituir um espaço diverso às perspectivas psiquiátricas. Uma ideia um tanto quanto inovadora no que diz respeito ao tipo de temática e ao lugar escolhido para executá-la tem grandes chances de situar o psiquiatra bi-posicionado num lugar/posição considerado pela maioria como suspeito, fazendo com que o profissional que dele aproxime-se seja mal visto ${ }^{139}$. A resistência pode não ser direta, mas seguramente ocorre mediante comentários que indicam o estranhamento com relação a uma temática tão diferente do que normalmente espera-se em relação ao ambiente acadêmico-científico.

Eu tive um caso específico que foi engraçado: durante o doutorado eu mandei, por exemplo, um artigo sobre essa área, para uma revista médica e recebi uma negativa sem nenhum comentário, sem nada ${ }^{140}$. Eu pedi um parecer porque veio um parecer completamente preconceituoso de que a psiquiatria, a medicina não deveria se ocupar disso porque isso não tem nada a ver com medicina e que isso é propaganda de religião. Coisas do gênero. Teve, eventualmente, episódios assim, mas isso foi esparso, foram coisas pontuais e que, de forma alguma, atrapalharam o andamento. (M1).

O NEPER/ ProSER pode ser visto como um lugar - e a religião, um objeto com posição baixa pelo fato de não haver os seus especialistas acumulado capital necessário (como, por exemplo, uma grande quantidade de artigos publicados). Muito provavelmente, esse lugar (ou esse objeto) não seja interessante para quem

\footnotetext{
${ }^{139}$ Em comunicação proferida no / Simpósio Paulista Saúde, Espiritualidade e Educação uma relação simbiótica, palestrante afirma que normalmente os médicos acham que estão expondo-se demais, "manchando sua carreira ao trabalhar com espiritualidade" (informação verbal).

140 Thomas Sazsz é um exemplo paradigmático de psiquiatra que devido a um posicionamento inovador no campo psiquiátrico foi vítima de incompreensão e perseguição pelos seus pares: "Durante toda a sua vida, Thomas Szasz demonstrou a coragem de defender seus princípios sozinho. Ele desafiou uma profissão poderosa e foi banido de publicações influentes; altas autoridades do governo fizeram todo o possível para arruinar sua carreira". (Disponível em <http://www.ordemlivre.org/textos> Acesso em: 20/10/09).
} 
tem capital alto no campo psiquiátrico no sentido de serem suspeitos, duvidosos, podendo levar ao rebaixamento de quem os procura. Na verdade, automaticamente, esse lugar e esse objeto são considerados baixos por ser o campo religioso dominado pelo campo científico. Entretanto, é importante lembrar que, segundo Bourdieu, a dignidade dos objetos sociais não ultrapassa a dignidade de quem ocupa os lugares. Em outras palavras, a dignidade científica do objeto depende do capital intelectual investido no estudo e não no objeto de escolha em si (informação verbal) $)^{141}$.

Ainda que tenha havido a adesão inesperada de um número acima do previsto - com profissionais interessados pela temática, porém, sem espaço para expô-la ${ }^{142}$-, o estabelecimento do NEPER/ProSER foi facilitado, em grande medida, pelo apoio de profissionais (simpatizantes da temática) com capital científico considerável e que, por isso, eram respeitados no IPQ.

Quando a gente começou esse estudo, todo mundo tinha medo de resistência e na realidade a resistência foi muito menor e havia muitas pessoas que tinham interesse no tema, mas que nunca haviam comentado isso. No contexto médico, no contexto acadêmico começava a ficar mais à vontade para falar sobre esse tema. Então nós começamos a descobrir muitos aliados, muitas pessoas realmente interessadas no tema que nunca tinham tido a oportunidade de falar por resistência, por falta de espaço, por algum temor [...] Eu, pessoalmente, achei que ia ter muito mais resistência do que efetivamente houve. Dentro do Instituto especificamente, a gente teve, de um modo geral, muitos apoios. É claro que a respeitabilidade, por exemplo, do Professor Neto também foi muito importante, uma pessoa que já tinha feito uma livre-docência nessa área ${ }^{143}$, um professor muito respeitado no Instituto. Com isso, as pessoas ficavam um pouco mais tranquilas de que estavam sob uma boa guarda. Eu acho que tem um pouco isso: esse modo meio dele ser um avalista, digamos assim, do grupo. Acho que isso apoiou muito. Ele é uma pessoa que apoia muito vários tipos de abordagens, de estudos. Ele está muito aberto pra isso. Então, isso foi muito importante. (M1).

O capital (que é o núcleo do mundo social na perspectiva bourdieusiana) aparece como um aspecto importante para pensar não somente as relações entre os

\footnotetext{
${ }^{141}$ Informação obtida com François Bonvin em reunião para discussão do projeto de pesquisa desta tese.

${ }_{142}$ Segundo um psiquiatra neutro, ao ser indagado se existe um espaço para que os religiosos participem das reuniões clínicas: "Conhecendo a instituição Instituto de Psiquiatria em especial não existe um espaço definido pela instituição. Mas acho também que não tem uma proibição desse espaço. Como em todos os lugares, os espaços só vão surgir se as pessoas ocuparem (M26).

${ }^{143}$ Aqui se nota a referência à importância das titulações.
} 
campos, mas também as relações dentro de um campo. No campo psiquiátrico, assim como nos demais, existem posições associadas a mais capital e a menos capital. Normalmente no campo científico, no campo acadêmico há uma forma de capital apenas, ou seja, uma forma de classificação, a qual se relaciona a quem tem mais ou tem menos capital científico. Se o campo funciona como deveria, essa é a única consideração que se faz (BOURDIEU, 1983b, p. 89). Seria um campo subordinado se estivesse preso a outras formas de capital. Nesse caso, psiquiatras bi-posicionados - inovadores no campo - assumem uma responsabilidade tal que os obriga a deter muito capital (muitas publicações, títulos elevados, etc) para impor uma mudança que funcione.

\subsection{INSTITUTO DE PSIQUIATRIA (IPQ): A CONSTITUIÇÃO ATUAL}

\subsubsection{Organicista e biologicista ${ }^{144}$}

Aprender medicina es como "aprender un idioma". [...] Y ser competente en medicina depende de aprender a háblar y a leer ese idioma. (Byron J. Good, aspas do autor).

Os psiquiatras de um modo geral (bi-posicionados, mono-posicionados, neutros/ambíguos) não poupam $\mathrm{O} I \mathrm{PQ}$ ao revelarem aspectos que, mesmo aparentemente óbvios, não deixam de evidenciar alguns segredos dessa que é uma das mais renomadas instituições de atendimento no que diz respeito a questões de saúde e doença mental do Brasil. Discorrem, mormente, sobre um ponto que reverbera sobre o restante das ações: o modelo caudatário do organicismo e do biologicismo, aquele cujo corpo teórico outrora caucionara "as esperanças dos eugenistas"145 (COSTA, 2007, p. 20). Segundo Silva (2001, p. 85), no final do século $\mathrm{XIX}$, com o profundo desenvolvimento de "pesquisas anatomopatológicas,

\footnotetext{
144 Aqui psiquiatras (4 bi-posicionados, 5 neutros e 1 mono-posicionado) fazem apreciações quanto ao modelo médico. No geral todos se mostram críticos a esse modelo.

${ }^{145}$ Para os eugenistas, a doença mental seria transmitida hereditariamente (COSTA, 2007, p. 20).
} 
terapêuticas e farmacológicas", a doutrina organicista ${ }^{146}$ torna-se hegemônica, "ampliando a confiança no tratamento físico". No século XX a psiquiatria orienta-se para a biologia e a bioquímica (SILVA, 2001, p. 85).

É necessário, todavia, esclarecer que a intenção aqui, para além de críticas à perspectiva médico-psiquiátrica, é a de fazer notar o seu imenso poder e procurar entender de que forma a ela é conferida tamanha autoridade. Muitos autores refletiram sobre o modelo psiquiátrico e, no entanto, não pretendiam com isso "denegrir os psiquiatras" (COOPER, 1989, p. 35), muito menos "desmascarar a psiquiatria" (SZASZ ${ }^{147}, 1979$, p. 14), tencionavam sim contribuir para uma postura crítica frente às diferentes propostas de encaminhar a prática psiquiátrica. Dessa feita, tem-se consciência de que no interior do modelo psiquiátrico apresentado aqui existem aqueles profissionais com bons propósitos, engajados em posicionamentos que acreditam ser os mais adequados (eticamente e instrumentalmente) ao exercício da sua profissão.

A visão, aceita por grande parte dos psiquiatras entrevistados, é a de que o HCFMUSP, e especificamente o IPQ, traz desde sempre no seu cerne um modelo teórico e prático voltado para o biológico, descartando normalmente a utilização de concepções diversas do ser humano que levem em consideração todo o seu contexto cultural. Assim, percebe-se que os psiquiatras vivem um paradoxo: se veem inseridos num modelo, mas não se identificam totalmente com ele. Possivelmente eles estejam atentos às diferenças que separam as doenças físicas das doenças mentais. Não é porque a fenomenologia das primeiras independa do caráter sócio-econômico e político do meio social em que ocorrem que a fenomenologia das segundas venha a ser da mesma forma. Muito pelo contrário, como acredita Szasz (1979, p. 54), as manifestações da doença mental "dependem e variam de acordo com o caráter educacional, econômico, religioso, social e político do indivíduo e da sociedade onde ocorrem". É, assim, o desencontro entre o biológico e o cultural o grande gerador de polêmicas.

Isso explica na visão de um entrevistado, por exemplo, o espanto de muitos psiquiatras quando descobrem que existe no IPQ um Núcleo de Estudos sobre

\footnotetext{
${ }^{146}$ De acordo com Costa (2007, p. 56) "nas primeiras décadas do século XX, era extremamente difícil ao médico psiquiatra escapar à influência do organicismo, que vivia, então, seu apogeu teórico".

${ }^{147}$ Psiquiatra e crítico feroz do modelo psiquiátrico institucional.
} 
Espiritualidade: "Nossa, mas um grupo de religiosidade no Instituto de Psiquiatria da USP!?" (M1). A surpresa reside justamente no fato de que "a visão que se tem é que o Instituto de Psiquiatria da USP é muito biológico, é muito organicista" (M1), é um lugar onde predomina fortemente "essa coisa empírica, biologicista" (M14). Parece que não são poucos os profissionais que acreditam que isso seja algo verdadeiro e posto em prática normalmente.

No final do século XIX [...] a medicina começou a buscar a questão da patofisiologia, patogenia, microbiologia, começou-se a buscar causas sempre orgânicas, materiais e objetivas e começou-se a desprezar, muitas vezes, as causas sociais, psíquicas, ambientais ou mesmo a dimensão espiritual das pessoas. (M1).

Essa característica que marca a produção do conhecimento médico e a sua realização prática faz com que o ser humano doente seja visto "como um imenso camundongo" (M22). Nesse tipo de perspectiva apenas os sintomas são considerados, descrevem-se as doenças e os seus respectivos tratamentos. Para-se por aí. O homem deixa de ser visto na sua totalidade, seu contexto cultural é suprimido. A empiria torna-se o fundamento de tudo. A mentalidade técnica predominante faz com que alguns psiquiatras utilizem argumentos como 0 de excesso de trabalho, por exemplo, e deixem de dar atenção a questões importantes (emocionais, espirituais) que podem, na verdade, ser aliadas do tratamento.

Às vezes, o agente de saúde é muito técnico, ele está muito focado. Tem médico que diz que já tem muito trabalho porque ele já tem o raciocínio técnico, muito focado no exercício técnico da profissão. Só que ali na frente dele não tem um cérebro epilético, tem um ser humano que tem necessidades complexas, também físicas, mas também emocionais, espirituais que, se você não dá atenção a isso, a eficácia/eficiência da sua assistência pode ficar prejudicada. E, se você acolhe emocionalmente a pessoa, dá conforto para ela, respeita as necessidades espirituais dela, aquilo vai se somar ao seu tratamento e o resultado é melhor. (M27).

Isso remete a outro momento recente da história da psiquiatria exposto por Basaglia (1985, p. 263, aspas do autor) que, ao descrever a situação do doente mental na Itália, coloca de forma bem crítica a maneira com que o corpo médicopsiquiátrico conduzia a relação com o paciente. Ao ficar ancorada no empirismo médico e derivar deste seus valores, segundo o autor, "ainda hoje a maioria dos 
professores universitários, com os mesmos gestos de seus professores do século $\mathrm{XIX}$, conduzem o doente mental ao anfiteatro e o 'demonstram' aos estudantes, como se exibissem um fígado cirrótico sobre a mesa de anatomia: os movimentos, as palavras do enfermo, continuam sendo 'fatos', não atos situados num contexto". Também Szasz (1979, p. 31) faz alusão a este tipo de comportamento que, segundo ele, vigora entre os médicos, que é o de tratar os pacientes como objetos a serem classificados e manipulados. Tal postura pode ser exemplificada pelo uso frequente de expressões como "caso", "material clínico", em vez de falarem de pessoas. Observa-se, desse modo, que o objetivo é o de identificar, descrever e classificar as doenças simplesmente ${ }^{148}$.

Uma crítica muito feroz é feita a um modelo que leva em conta apenas os sintomas ("a medicina atual é muito superficial" - M16), que não se interessa a fundo pelo doente, mas pela doença em si. Com essas feições, ela é acusada de ser uma "má psiquiatria" (M15), já que destituída do caráter humano e social. O paciente deixa de ser visto em todas as suas vertentes, direcionado apenas para "um modelo muito ou biológico ou psicológico" (M22). Evidentemente que um modelo como esse não abre espaço para questões outras - "Dá pra perceber isso: descreve-se magistralmente as doenças e os tratamentos, mas não descreve [sic] a pessoa" (M22). A atuação deficitária em relação ao alcance da totalidade dos aspectos que englobam a vida humana faz com que o profissional vislumbre um sujeito dividido: sujeito-sintoma versus sujeito-global.

Eu acho que estamos em uma ideologia hoje, do século XX e XXI, de tratar só dos sintomas. "Você está com impotência, toma Viagra. Você está com depressão, toma Prozac. Você está comprando muito, toma tal coisa." Tudo bem, não sou contra os remédios. Mas por que você está impotente? Por que você está deprimida também? Porque você está comprando bastante? [...] Então, hoje o homem está sendo visto como um imenso camundongo. Só estamos tratando sintomaticamente. (M22).

Saúde e doença não podem ser vistas de forma restrita, assim acredita M3 ao afirmar que "definir o que é saúde não é só a coisa física, se o coração está batendo ritmicamente, se o pulmão está funcionando, ou no caso da psiquiatria, se

\footnotetext{
${ }^{148}$ Nesse sentido, levando em consideração que os sistemas de classificação são criados pelas pessoas, "é necessário que se esteja a par de quem criou as regras e com que propósito" (SZASZ, 1979, p. 46).
} 
as funções psíquicas estão funcionando adequadamente" (M3). Estão em jogo outras questões, como o bem-estar do indivíduo relacionado à sua vida em sociedade. Destarte, entender o ser humano e como ele vive, resumindo, sua cultura, não é irrisório para a compreensão do binômio saúde-doença.

É fundamental você entender o que é aquela pessoa, o que ela pensa, como ela vive. A essência da psiquiatria é essa: antropológica. Se você não entender o que é o ser humano e como ele vive, a cultura dele, é impossível você entender se aquilo é doença ou não. Você simplesmente checar se ele preenche critérios, eu acho que é uma má psiquiatria [...]. (M15).

Pensar anatomicamente o ser humano é a visada médica básica. $\mathrm{Na}$ verdade, o médico, como descreve Good (2003, p. 140), "chega a habitar en otro mundo", um mundo muito específico de experiência não acessível ao cotidiano: "Aprender medicina es desarrollar el conocimiento de este mundo vital específico y exige adentrarse en un sistema de realidad específico". Tal mundo é tão específico que "incluye modos especializados de 'ver', 'escribir' y 'hablar'” (IBIDEM, aspas do autor). No mundo vital da medicina, o corpo se reconstrói como um "cuerpo médico, muy distinto de los cuerpos con los que nos interrelaciones en la vida cotidiana [...]"149 (IBIDEM, p. 141). Assim, uma reconstrução da pessoa mais adequada aos objetivos da medicina conduz a que ela seja identificada "como un cuerpo, un caso, un paciente o un cadáver" (IBIDEM, p. 144). Refletindo sobre tal postura, este mesmo autor previne quanto ao fato de a pessoa ser uma construção cultural para a qual o bom médico deve estar atento.

La persona es una construcción cultural, un modo de verse a sí mismo y a los demás complejo y culturalmente moldeado, y se requiere una 'labor' cultural para reconstituir la persona que es objeto de la atención médica. Esta reconstrucción de la persona es esencial para que un estudiante llegue a ser um médico competente. (IBIDEM, aspas do autor).

\footnotetext{
149 Segundo o autor, aprender a ver anatomicamente acaba não se limitando ao laboratório ou aos espaços próprios à medicina. Isso se estende ao mundo lá fora. É o que relata enquanto observador de uma classe de anatomia: "Trás salir de una clase de anatomía como observador, solía ir paseando por la calle y, de pronto, me 'veía' como un cuerpo entre tantos, más que como una persona entre tantas. Tenía la sensación de fijarme en las características anatómicas de las personas con las que me cruzaba, más que percibirlas como personas con características sociales o vidas que pudiese imaginar" (GOOD, 2003, p. 144, aspas do autor).
} 
Para fazer uma "boa psiquiatria", o médico "tem que conhecer a fundo a vida do doente, de onde ele veio, como é a casa, que igreja ele frequenta, se a família é da mesma religião ou não, qual é a religião" (M16). Entretanto, os profissionais são acusados, por vezes, de desinteresse ${ }^{150}$, insegurança para lidar com outras questões que não a biológica. Por trás disso, parece estar ocultado um resguardo do psiquiatra em relação ao doente - "Um certo medo, uma certa defesa do médico: não deixo o paciente falar, dou o remédio, peço o exame, pronto e acabou" (M22). Ao contrário, o sujeito do sofrimento deve ser apresentado, para além da enfermidade, como um agente narrativo (GOOD, 2003, p. 156). Szasz (1979, p. 132) compartilha de tal visão. Segundo este autor, a despeito da sua não apreciação, há uma perspectiva na psiquiatria de que "as chamadas doenças mentais são mais idiomas do que doenças". A partir desse enfoque, fala-se em comportamento simbólico, "linguagem da doença". Ao tratar a "doença mental" como linguagem não faz sentido falar de "causas", "tratamentos", "curas"; ao contrário, o que caberá indagar apenas é de que modo ela foi aprendida e o que ela significa. Na medida em que se fala em termos de comunicação, de linguagem, torna-se possível reconhecer o seguinte: "Entre uma diversidade de formas comunicativas, cada qual tem sua própria raison d'être, e que, dependendo das circunstâncias em que se encontram os comunicantes, todas podem ser igualmente 'válidas'” (SZASZ, 1979, p. 133, destaque e aspas do autor). A ênfase dada aos símbolos em detrimento da patologia em si abre possibilidade de tratar a questão em termos de significação, possibilitando relativizar o que se acredita ser a "doença mental".

A questão espiritual, segundo alguns psiquiatras, também é importante e faz parte desse contexto cultural do paciente a ser explorado pelo profissional ("Veja bem: o homem, aquele ser vivo psicossociocultural e, na [sic] minha opinião, espiritual. Essa parte espiritual não pode ser desprezada no indivíduo" - M23). Acredita-se que ela deva ser valorizada inclusive como uma forma de humanização. Há até mesmo aqueles que estão convencidos de que o profissional que é religioso

\footnotetext{
${ }^{150}$ Uma das causas da falta de interesse dos estudantes de medicina [no caso da escola de medicina de Harvard] pela conversação com o paciente, segundo Good (2003, p. 153), deve-se "a su percepción de que los actos verbales más importantes en la práctica de la medicina no son las entrevistas a los pacientes sino su presentación". As apresentações de casos se passam da seguinte forma: nas histórias descrevem-se as pessoas como pacientes e como problemas médicos. Segundo o autor, para além da ideia de que as estratégias narrativas são apenas reflexos da experiência, as histórias devem ser pensadas como um meio "para organizar e interpretar la experiencia, sirven para proyectar experiencias idealizadas y anticipadas, y son un modo específico de formular la realidad y un medio idealizado de interrelacionarse com ella" (IBIDEM, p. 156).
} 
é mais flexível, menos biológico e trabalha mais com o sentimento dos pacientes (E4). Entretanto, os profissionais de saúde têm, durante a sua formação, uma abordagem que não favorece um bom entendimento do aspecto religioso dentro da cultura brasileira. Este é visto parcialmente e encarado muitas vezes de forma muito mística (M11). Normalmente os médicos são reacionários no que diz respeito à religião, como se ela fosse algo apenas relacionado a dogmatismo (M11).

Existem opiniões céticas (M14) em relação aos companheiros de profissão principalmente aos companheiros do IPQ. É com grande acuidade que é apreciado esse conteúdo tão presente no modelo psiquiátrico vivenciado nos muros do Instituto, o qual, além de ser composto por pessoas mais biologicistas ${ }^{151}$ (se comparado a outros serviços), é também um serviço que "quando parte para essa seara do psicológico ou do interpessoal tem uma concepção mais cognitiva, mais comportamental" (M14). No limite, esses profissionais eludem, para além do âmbito da espiritualidade, questões psicológicas, sociais (M14). Numa tal mentalidade um tanto quanto especiosa, tudo se passa como se o indivíduo-biológico pudesse ser visto separado do indivíduo-antropológico. Tal qual atesta Good (2003, p. 139), é possível observar no seio da medicina o grande poder que tem a ideia basicamente, se não exclusivamente, biológica: "no es que se ignoren los aspectos relativos al comportamiento y a la experiencia, por supuesto que no (por lo menos por parte de los buenos clínicos), pero se tratan como aspectos independientes del verdadero objeto de la práctica médica". Tudo se passa como se os aspectos socioculturais não tivessem qualquer interface com os aspectos biológicos, cada qual com caminhos distintos e não interligados.

A asserção atinente ao biologicismo e organicismo do IPQ que foi frequentemente trazida para debate não pode unicamente ser cotejada em relação ao que pode haver de antropológico e cultural do indivíduo assistido. Deve-se, também, considerar que a questão não reside simplesmente no fato de o médico não ver o lado humano do paciente, mas no fato de que o tipo de trabalho para o qual ele está voltado e o qual ele escolheu tem a ver com o modelo organicista ${ }^{152}$. Faz-se necessário lembrar neste momento, como sugerido por Szasz (1979, p. 78), que "ao estruturar suas crenças e comportamento de acordo com o modelo médico,

\footnotetext{
151 "São pessoas que têm uma concepção do sofrimento psíquico mais biológica" (M14).

152 Comentário feito por psiquiatra em reunião do atual ProSER.
} 
o psiquiatra consegue participar do prestígio e poder dos médicos". O comportamento organicista dos psiquiatras pode ser explicado pela necessidade de reconhecimento dentro do campo médico mais amplo. $O$ que, conforme a perspectiva bourdieusiana, relaciona-se à peculiaridade do campo científico, no interior do qual o reconhecimento válido é aquele proveniente dos paresconcorrentes.

A grande questão a ser feita é, na verdade, se os psiquiatras realizam esse jogo sem uma autorreflexão, ou seja, sem a consciência das regras do jogo (SZASZ, 1979, p. 49). Aqui é pertinente retomar a reflexão sobre a concepção de habitus enquanto automatismo em contraposição a possibilidade de haver reflexividade nas atitudes dos sujeitos. Estes - que segundo aquela concepção são agentes nativos que sabem o que estão fazendo sem o saber -, ao mesmo tempo em que parecem ser impelidos por forças maiores atuantes no campo médico, não são marionetes, pois possuem liberdade de ação, de escolhas.

Pode-se encarar o posicionamento dos psiquiatras como se referindo a dois tipos de linguagens distintas: uma organicista-biologicista e outra humanista-cultural. A primeira tem se sobressaído notadamente, o que não elimina, contudo, a introdução e expansão da segunda. A atenção à religiosidade/espiritualidade, defendida pelos psiquiatras bi-posicionados, pode ser muito provavelmente uma tentativa bem intencionada (talvez não consciente) de fugir ao organicismobiologicismo. Por esse motivo, tal atitude não deve ser confundida com "ingenuidade ou obscurantismo, e sim com uma autêntica tomada de posição em relação à função e formação tradicional do psiquiatra" (SILVA, 2001, p. 90, destaque nosso). Trata-se de uma inflexão nas regras do jogo do campo psiquiátrico que comporta uma atitude revolucionária de tentativa de mudança do modelo norteador da prática da psiquiatria.

Entretanto, um domínio tão diversificado como o psiquiátrico (que tem a possibilidade de amalgamar questões biológicas, psicológicas, culturais, sociais) não pode simplesmente ser resumido à contraposição do par de opostos organicistabiologicista versus humanista-cultural. A psiquiatria, "encruzilhada de múltiplas pertinências", tal como declara Oury (1991, apud SILVA, 2001), não deve ser reduzida a esta ou aquela classificação, porquanto ela ultrapassa tais divisões e requer uma irmanação dos diferentes aspectos presentes na vida humana. 


\title{
3.2.2 Formação médica: humanismo versus superespecialização ${ }^{153}$
}

\begin{abstract}
O móvel do jogo científico constitui em si mesmo um móvel do jogo científico e, por conseguinte, não existem, no campo, juízes que não sejam também partes. (Meditações pascalianas, Bourdieu).
\end{abstract}

A crítica a um modelo organicista-biologicista tem a sua contrapartida na defesa de uma postura mais humanista-cultural da psiquiatria como ciência, a qual deveria ver "o homem inserido na sociedade dele, na cultura" (M22). Isso quer dizer que "não adianta só a parte científica, não adianta só a parte medicamentosa ou uma parte psicoterapêutica, muitas doenças precisam de uma visão pluridimensional - trabalho, vida social, hobbies, valores que a pessoa tem, inclusive políticos, religiosos" (M22). Tirar os sintomas do doente e não Ihe proporcionar outras formas de estar na vida é o mesmo que desconectá-lo da realidade, tirar-lhe a vida ("Muitos pacientes que a gente só deu remédio e tirou os sintomas se mataram. Ficaram vazios. Foi tirado aquele sintoma da doença e não the deu nada" - M22). Uma visão do ser humano na sua totalidade ultrapassa, nesse sentido, a dicotomia biológico/cultural e coloca em relevo a necessidade de concatenar os diferentes ângulos a partir dos quais o ser humano deve ser percebido.

Acredita-se que seja dever do médico identificar no paciente o que é importante para ser abordado. Parte do humanismo do médico reside nessa sensibilidade de "sacar um pouquinho o que aquela pessoa está precisando, qual é o pão que ele está precisando" (M22). O humanismo não passa necessariamente pela religião. Independente da crença ou não crença do profissional de saúde, acredita-se que é possível ser "sensível ao outro", "ajudar além daquilo que exerce" (AR3). A perspectiva que se atém ao homem enquanto ser integral não pode direcionar-se a apenas um ou outro setor da vida humana.

A despeito disso, evidencia-se a falta de sensibilização na formação dos médicos, a qual não coloca em foco questões que tratem do lado social, filosófico. Existe um déficit quanto a isso no processo de formação dos médicos ("A gente não

${ }^{153}$ Aqui psiquiatras (4 bi-posicionados, 8 neutros e 2 mono-posicionados) fazem suas apreciações. A postura é crítica, mostrando como é a formação dos médicos em geral. 
tem o estudo dessa outra parte: a questão antropológica/sociológica, tudo isso está sendo deixado nos cursos de medicina, não sei exatamente por quê" - M2). Esse acontecimento pode estar relacionado a diversas questões, dentre elas a complexidade do curso de medicina, a qual torna inviável a realização de formações complementares, percebidas como tarefas extras. Esse déficit também pode estar ligado a uma tendência "mais cartesiana de encarar a medicina" (M2). Entretanto, uma formação humanista, alguns acreditam, otimiza a atuação profissional do médico ("deixa você um médico melhor" - M6). Ela é, desse modo, enxergada de forma positiva.

Portanto, uma formação geral em contraposição a uma superespecialização técnica é o que falta aos médicos na sua educação - opinião compartilhada por alguns profissionais. A despeito disso, muitos médicos se identificam com esse modelo, eles "querem a superespecialização, [...] estão identificados com outro modelo de medicina" (M14). Assim faz todo sentido quando Costa em A história da psiquiatria no Brasil afirma que "hoje em dia, a prática psiquiátrica continua padecendo de sintomas que revelam a presença atuante do vírus dogmático" (COSTA, 2007, p. 34). No momento, isso pode ser apreciado mediante o empenho em relação à especialização ou delimitação de competências. Sob alegação do necessário aprofundamento teórico e prático em determinadas áreas do conhecimento, "os defensores do discurso competente absolutizam posições de princípio, para daí condenarem como ecletismo ou superficialidade qualquer proposta de olhar o sujeito humano como uma realidade plural e imprevisível" (IBIDEM). O fato de os médicos "quererem" a superespecialização diz muito do habitus enquanto disposição incorporada e que é, portanto, sentida como uma necessidade.

Para romper com essa mentalidade, acredita-se ser necessária uma mudança dos paradigmas da medicina e do fazer médico (M14). Trata-se de uma autocrítica (M17) feita a fim de propor uma nova maneira de encarar a profissão de médico, a qual deve deixar de ser vista unicamente do ponto de vista medicamentoso. Ao ter na sua base de funcionamento a superespecialização, o campo médico-psiquiátrico requer, dessa forma, profissionais que possuam a competência necessária - o habitus do qual fala Bourdieu - para sentir a necessidade desse tipo de proposta, ou melhor, desse produto. Ou seja, predomina 
(no ensino, na pesquisa e no atendimento clínico) um habitus voltado para os aspectos orgânicos/biológicos em detrimento dos aspectos socioculturais. A interiozação - e por isso a familiarização - é de uma mentalidade que prioriza um dos aspectos do sujeito-paciente. O que se apreende em "casa de Arnaldo" ${ }^{154}$ desde tempos remotos é a valorização das questões biológicas. Bom ou mau? Não é o propósito deste estudo cerrar fileiras contra esta ou aquela visão. É dado aos próprios sujeitos que compõem esse ambiente a liberdade de realizar o seu julgamento.

Faz-se necessária a introdução de cursos humanísticos na Faculdade de Medicina, é o que se afirma em coro. Segundo essa autocrítica médica, alguns profissionais não dão a devida importância a essas questões e, às vezes, até as desprezam, mas de acordo com alguns psiquiatras, é preciso fazer o esforço de reformular o curso e mudar a perspectiva prevalente até então. A despeito dessa necessidade, a falta de aderência e engajamento dos alunos, desinteressados de um modo geral pelas humanidades, resulta numa falta de demanda e, consequentemente, inviabiliza a mudança de mentalidade (M10, M14).

Foram matérias, horários, principalmente no comecinho da graduação. Além de uma ênfase nos orientadores para dar [sic] uma melhor formação nesse aspecto. Entretanto, na prática isso não foi efetivo. Os cursos, eu não sei como estão agora, na nossa época não eram satisfatórios em termos dos objetivos que eles queriam alcançar, as pessoas ficavam desinteressadas, mesmo as pessoas interessadas em termos éticos/filosóficos. (M18).

A gente tem algumas coisinhas de bases humanísticas da medicina no começo, cursos de ética e uma ou outra coisa, mas é sempre um apêndice, não é uma coisa central em nenhum curso. Mas esse curso, mesmo as coisas centrais dele ficam a desejar. Pelo menos na minha época, sete anos atrás. (M10).

Não obstante, a falta de demanda por uma formação humanística é certamente a consequência imediata da inexistência de oferta curricular nesta mesma área: "Na verdade o currículo de medicina tem se tornado cada vez mais centrado no modelo médico-biológico e por mais que o discurso seja do

${ }^{154}$ A Faculdade de Medicina da USP é também denominada "casa de Arnaldo", em homenagem ao seu fundador, Arnaldo Augusto Vieira de Carvalho. 
biopsicossocial $^{155}$, o psicossocial acaba ficando bastante de lado" (M14). Às vezes até ocorre o esforço de melhorar essa formação na graduação, mas os objetivos mostram-se enfraquecidos. Outras vezes coloca-se em dúvida se a idealização de humanizar o médico é mesmo possível: "Existem vários cursos de humanização dentro da medicina, mas eu não sei até que ponto eles conseguem humanizar o médico" (M12). Desse modo, é possível perceber o pessimismo em relação ao assunto, a "descrença" de que uma mudança seja, realmente, concebível.

Paralelamente a essa visão questionadora dos propósitos e da existência, de fato, de uma humanização, vê-se ainda uma parcela de profissionais que afirmam ter vivenciado esse tipo de formação:

$\mathrm{Na}$ faculdade a gente tinha cursos organizados por alunos, mesmo. Eu fiz um curso de medicina além do corpo. Lá a gente tem cursos de bases humanísticas que eles dão principalmente preceitos éticos. A gente discutia bastante religião. $E$ tinha uma disciplina que vinha até o padre falar, budista falar por que a gente precisava conhecer o discurso dos pacientes. (M24).

A conclusão daqueles que são mais "sensíveis aos aspectos religiosos" é de que, no geral, os médicos são formados sem nenhum tipo de treinamento em relação à religiosidade (M1). E, ipso facto, quando se fala de religiosidade é de um modo negativo (M1), por exemplo, ao tomar como aspecto ilustrativo o paciente "que parou de tomar remédio porque a religião dele falou que ele não deveria tomar" (M1). Ou seja, quando o assunto é religiosidade/espiritualidade, a balança pende mais para o lado da contraprodutividade e dos malefícios.

A parte antropológico-cultural aparece pouco, segundo alguns, ela começou a ser considerada apenas recentemente porque anteriormente era "aquela grade certinha: anatomia, patologia, tudo direitinho" (M3). Uns recordam-se de disciplina que tratava de influências culturais, de questões mais sociais, mas não exatamente de religiosidade (M10). Outros falam de uma mesma disciplina cujo nome seria "influências culturais da medicina" ou "aspectos culturais da medicina", onde seriam bem contempladas questões religiosas (M24). Quando indagados sobre ter alguma disciplina que trate de questões relacionadas à religião, a demanda aparece como sendo mais ampla; ou seja, por uma formação mais humanista (não

${ }^{155}$ Costa (2007, p. 30) fala da noção de indivíduo enquanto unidade biopsicossocial como um chavão da psiquiatria preventiva dos anos 70 , com finalidades político-sociais distantes da problemática específica da saúde/doença mental. 
necessariamente sobre religião), visto que se acredita que as áreas afins das ciências humanas (a antropologia, a sociologia, a filosofia) seriam tão importantes quanto a religião ou até mesmo tenham mais repercussão entre os profissionais do que esta. Estar atento aos aspectos humanísticos mais gerais deixa o profissional "um médico melhor do ponto de vista humano" (M15). A partir desse tipo de formação, o profissional começaria a conhecer a diversidade e a lidar melhor com as diferenças, isso incluiria a religião inevitavelmente.

Se, por um lado, é recorrente a ideia de ser necessário ao médico enxergar o paciente como um todo, e nesse todo está inclusa a religiosidade/espiritualidade (M7); por outro lado, é preocupante, para alguns, a possibilidade de, se ensinado de uma maneira muito formalizada, perder-se a subjetividade, a qual seria "mais importante do que a religião" (M15). Ou seja, alerta-se para a possibilidade real de se perder "a escuta do paciente" no sentido de se ater a estereótipos religiosos, independente do que o paciente tenha a dizer: "Por exemplo, o paciente fala que ele é evangélico e você já parte de um pressuposto que evangélico é assim, assim e assim. E não entende para aquele paciente qual é a importância" (M15). Nesse sentido, o direcionamento para algo específico como a religião pode impedir que o paciente seja visto como um ser completo, com demandas as mais diversas (não menos importantes que o aspecto religioso).

A despeito daqueles que acreditam numa essência antropológica da psiquiatria, na esteira da superespecialização, os profissionais estão muito presos ao estudo dos medicamentos, esquecendo dessa forma que existe uma formação geral (M17), condenando as propostas que possam vir a existir de olhar o sujeito humano como uma realidade plural e imprevisível. Muitas vezes, como diria Costa (2007, p. 35 , destaques do autor), os objetivos "humanamente úteis são desqualificados ora como relativistas, decisionistas, voluntaristas, moralistas, irracionalistas, idealistas, intelectualistas etc ora como humanistas, reformistas, filantrópicos, franciscanos ou debilóides". Isso acontece porque, acreditam os seus defensores, o discurso competente é mais nobre e não pode ser confundido com "estas receitas caseiras de felicidade" (IBIDEM, destaque do autor).

$\mathrm{Na}$ verdade, o discurso competente aparentemente dividido em dois (o discurso do poder e o discurso do conhecimento) encerra, contrariamente, um só. $\mathrm{O}$ discurso dito competente pode ser entendido como aquele no qual a linguagem 
padece da seguinte restrição: "Não é qualquer um que pode dizer a qualquer outro qualquer coisa em qualquer lugar e em qualquer circunstância" (CHAUÍ, 2006, p. 19). Desse modo, o discurso competente embaralha-se com "a linguagem institucionalmente permitida ou autorizada". Ou seja, o referido discurso competente funde-se com um discurso no qual os interlocutores já foram antecipadamente reconhecidos e os lugares e as circunstâncias determinados de antemão; por fim, "no qual o conteúdo e a forma já foram autorizados segundo os cânones da esfera de sua própria competência" (IBIDEM). Do mesmo modo, Bourdieu discorre sobre o par especialistas/leigos (ao tratar do campo religioso). Os primeiros, socialmente reconhecidos como os detentores exclusivos de uma competência, de um capital específico em detrimento dos segundos, que são excluídos nesse processo. No que concerne ao campo científico, o autor fala da relação entre os pares-concorrentes, onde o valor de um produto só pode ser reconhecido por um produtor do mesmo campo.

Alguns reconhecem, apesar de toda a incúria por parte dos responsáveis, um esforço para melhorar a formação humanística para além da parte científica e da parte do relacionamento médico/paciente mais prosaico (M18). Entretanto, relacionado à temática religiosa, não se recordam de nenhum curso (M18). Críticas quanto à falta de atendimento multidisciplinar são trazidas à tona quando o fator religião/religiosidade é colocado em pauta.

Aqui dentro do Instituto, apesar de ser o maior centro de psiquiatria da América Latina, não tem atendimento multidisciplinar. São raros. Que a gente consiga trabalhar psiquiatra, psicólogo, assistente social e terapeuta ocupacional, quanto mais um religioso! Mas acho que faz todo sentido, sim. Religioso, advogado, tudo aquilo que o caso demanda. (M21).

Independente de um curso formalizado, existe uma busca que passa pelo interesse individual de cada profissional. Se este considerar a questão da religião/religiosidade como algo importante, por si só irá buscar informações a este respeito: "Por exemplo: teve um congresso em Salvador que a gente foi conhecer um centro de Umbanda ${ }^{156}$ e ler a respeito do assunto. Acho que psiquiatria é ter

\footnotetext{
${ }^{156}$ Necessário lembrar o papel desempenhado por religiões como o Candomblé e a Umbanda na reintegração dos doentes mentais à sociedade, no sentido de proporcionarem a esta modalidade de pacientes - na medida em que lhes dá abertura para lidarem com suas questões psicológicas - uma
} 
cultura geral. Tem que saber sobre religião, sem dúvida nenhuma. É mais do que é dado em aula" (M21). Para além do que pode ou não ser ofertado ao longo de sua formação, o psiquiatra tem a possibilidade de, particularmente, ampliar o seu leque de conteúdos e, assim, estar cada vez mais afinado com as necessidades humanas dos pacientes.

A maneira de ver apenas anatomicamente, biologicamente pode ou não ser praticada pelos psiquiatras, a depender de seu posicionamento frente ao mundo, de seus valores. Muito frequentemente salta aos olhos o modelo que desvincula o sujeito biológico do sujeito cultural, cindindo algo que é deveras concatenado. Entretanto, seria arbitrário colocar a psiquiatria e os profissionais aqui especificados numa postura de acatamento da mentalidade majoritária. Existe a contestação, como se pôde perceber nos relatos anteriormente citados, assim como existe a atitude de alheamento ${ }^{157}$.

\subsubsection{Estudos em saúde e espiritualidade}

O que mais penso, testo e explico: todo-o-mundo é louco. O senhor, eu, nós, as pessoas todas. Por isso é que se carece principalmente de religião: para se desendoidecer, desdoidar. Reza é que sara da loucura. No geral. Isso é que é a salvação da alma... (Grande Sertão Veredas, João Guimarães Rosa).

\footnotetext{
nova perspectiva para se olharem e para olharem o mundo à sua volta. O Candomblé, por exemplo, é uma religião que dá possibilidade às pessoas de lidarem com suas questões psicológicas e, grosso modo, permite a reintegração do indivíduo à sociedade. Todavia, apesar da sua importância na compreensão da "loucura" e do seu tratamento, esse tipo de religiosidade (como muitas outras) é negligenciada pelos profissionais da área de saúde (assim como é rechaçada por religiosos de orientação cristã). Dificilmente a participação real das religiões no processo terapêutico e de cura é consentida, ou até mesmo admitida como sendo um fato para o qual se deve dar uma maior atenção. Ao contrário, o que se percebe normalmente nas instituições de saúde é uma tendência em patologizar qualquer tipo de reação que não esteja ligada ao que o mundo científico determina como viável. O desconhecimento de aspectos da cultura brasileira e de religiões de matriz africana combinado a outros fatores 'tem produzido, historicamente, uma prática nos serviços de saúde, de psiquiatria e de saúde mental [em que] falas, gestos e modos de viver próprios dos adeptos de religiões afrobrasileiras são, não raro, considerados patológicos”. (CARVALHO, 2004, p. 52). Assim, "elementos que deveriam apontar para características específicas das religiões e das culturas" de grande parte da população negra são reduzidos a categorias nosológicas num processo que apenas contribui para agravar ainda mais o sofrimento dos sujeitos (IBIDEM).

${ }^{157}$ Alheamento que pode ser encarado sob a perspectiva do desinteresse bem como sob o ponto de vista da não identificação com o modelo vigente.
} 
Dentre aqueles que defendem uma postura mais humanista há os que vão mais longe ainda e levantam a bandeira da importância da religiosidade/espiritualidade no tratamento dos pacientes. Assim, no interior de todo um panorama de medicina superespecializada e sem um lugar de destaque para o lado humano ${ }^{158}$, um grupo de especialistas resolveu tomar uma atitude de engajamento e mobilização na tentativa de abrir espaço para um dos aspectos culturais que se faz presente na vida dos indivíduos: a espiritualidade. A maneira pensada para se começar a trazer à tona essa outra perspectiva foi a criação de um Núcleo de Estudos sobre Saúde e Espiritualidade (NEPER) ${ }^{159}$ e o desenvolvimento de pesquisas na área que comprovassem a importância desse aspecto na vida dos pacientes. Como relata um dos seus fundadores, a ideia inicial para estimular o projeto foi a formação, primeiramente, de "massa crítica" (M1), relacionada a um rigor metodológico, deixando para a posteriori a aplicação clínica. Isso foi muito importante para vencer resistências e haver aceitação, que era a preocupação fundamental naquele momento. Era necessário, portanto, mostrar claramente que o grupo de estudos não tinha nenhuma intenção proselitista ou de ser defensor de qualquer grupo religioso. Ao contrário, a ideia central era "estudar com rigor a religiosidade e saúde" (M1). Tanto que nos dois primeiros anos, segundo o depoente, restringiram-se a estudar basicamente aspectos metodológicos no sentido de "como realizar pesquisas de qualidade nessa área" (M1). Esse estilo adotado foi uma diretriz do NEPER, a qual facilitou em grande medida a aceitação do grupo e abriu muitas portas ${ }^{160}$.

Os profissionais que se aventuram na temática saúde/espiritualidade normalmente correm o risco de serem mal vistos, acabam sendo vítimas de

\footnotetext{
${ }^{158}$ Não é a intenção aqui insistir na clivagem natureza/cultura. Os termos humano, cultural foram utilizados para dar ênfase aos aspectos sociais que, via de regra, aparecem dissociados do tratamento medicamentoso. Laplantine $(2004$, p. 219) afirma que uma das propriedades das medicinas populares é o caráter abrangente da percepção da doença, ou seja, "a totalização homemnatureza-cultura, que se opõe à tendência à dissociação do homem, da natureza e da cultura, cujo corolário é a hiper-especialização".

${ }^{159}$ O NEPER foi fundado com base no DSM 4, o qual criou uma categoria denominada "Problemas espirituais e religiosos", em que estes se referem à pessoa que possui algum tipo de sofrimento, de dificuldade relacionada à religiosidade/espiritualidade, mas não necessariamente trata-se de um transtorno mental (M1).

160 Esses profissionais, engajados na temática religiosa, editaram um número sobre saúde e espiritualidade na Revista de Psiquiatria Clínica do IPQ-FMUSP. Segundo M1, eles conseguiram com que a revista tivesse um caráter abrangente, não se limitando a um único tipo de abordagem: "o máximo de abordagens possível, mas com um cuidado, com o rigor". (M1).
} 
preconceito dentro de sua comunidade acadêmica, que não vê com bons olhos a "mistura" de questões que consideram como sendo totalmente fora do contexto médico $^{161}$. A tentativa de inserir uma nova proposta de pensar a psiquiatria, muito provavelmente, poderá ser execrada por aqueles que se consideram os detentores do saber legítimo. E nisso reside, geralmente, a dinâmica do campo o qual se constitui por lutas das quais é necessário cada vez "procurar as formas específicas, entre o novo que está entrando e que tenta forçar o direito de entrada e o dominante que tenta defender o monopólio e excluir a concorrência” (BOURDIEU, 1983b, p. 89). Sempre haverá movimentos inovadores no campo, tentativas de inflexões no modo de pensar que, frequentemente, serão postas em questão num movimento de reação ao novo e de garantia da soberania do modelo vigente.

Pertencer a um grupo profissional, segundo Bourdieu (2004b, p. 20), "exerce um efeito de censura que vai muito além das coações institucionais e pessoais: há questões que não são colocadas, que não podem ser colocadas, porque tocam nas crenças fundamentais que estão na base da ciência e do funcionamento do campo científico". Tanto é assim que um dos entrevistados a favor de pesquisas na área de saúde e espiritualidade afirma que estudar espiritualidade "é um fator anti-tenure" (M1) - o tenure, segundo M1, seria a estabilidade adquirida pelo professor ${ }^{162}$.

Um campo, e também o campo científico, se define entre outras coisas através da definição dos objetos de disputas e dos interesses específicos que são irredutíveis aos objetos de disputas e aos interesses próprios de outros campos (não se poderia motivar um filósofo com questões próprias dos geógrafos) e que não são percebidos por quem não foi formado para entrar neste campo (cada categoria de interesses implica na indiferença em relação a outros interesses, a outros investimentos, destinados assim a serem percebidos como absurdos, insensatos, ou nobres, desinteressados). Para que um campo funcione, é preciso que haja objetos de disputas e pessoas prontas para disputar o jogo, dotadas de habitus que

\footnotetext{
${ }^{161}$ Em palestra proferida durante o / Simpósio Paulista: Saúde, Espiritualidade e Educação, expositor afirma que dos 3.110 (três mil cento e dez) médicos do HCFMUSP, nenhum estava presente no referido simpósio. Ele acredita tratar-se de um processo educativo que irá se formando aos poucos. (informação verbal).

162 Bourdieu (2004a, p. 55) discorre rapidamente sobre o "tenure". Ao falar do campo científico, ele comenta um dos seus paradoxos, o de dever sua autonomia ao financiamento pelo Estado, possuindo assim o que ele chama de "dependência na independência (ou o inverso)". Disso, o autor, afirma que pode surgir uma outra falsa antinomia que é "servir-se do Estado para liberar-se da influência do Estado; pode-se tirar partido das garantias de autonomia que o Estado dá - por exemplo, as posições tenures, como dizem os anglo-saxões, de titular irremovível - para afirmar sua independência com relação ao Estado".
} 
impliquem no conhecimento e no reconhecimento das leis imanentes do jogo, dos objetos de disputas, etc. (BOURDIEU, 1983b, p. 89).

Quem se opõe a uma carreira já traçada, a um modo de agir existente no campo, deverá dar o máximo de si sem esperar um retorno imediato ou lucros importantes, "posto que eles têm contra si toda a lógica do sistema" (IDEM, 1983a, p. 138). Os heréticos, quando colocam em discussão "os próprios princípios da antiga ordem científica", ao mesmo tempo em que arriscam ter o seu tema não reconhecido pelos outros, fazem com que haja um fortalecimento do campo, pois lhe dão o seu devido valor. Ou seja, mesmo no desacordo eles estão de acordo quanto à sua importância.

[...] a gente ouvia de várias pessoas dentro do próprio Instituto, algumas pessoas que comentavam: "Nossa, mas que estranho mexer com isso!" Ou quando, por exemplo, eu fui fazer meu doutorado investigando a mediunidade: "Você vai mexer com isso? Não é melhor pegar outra coisa? Isso vai te trazer confusão, vai ter dificuldade para você publicar ou pra defender" [...] E eu acho que nos últimos vinte, trinta anos, quando se começou a realmente fazer estudos a respeito e não só se basear na autoridade de autores de destaque, começou-se a se reverter essa situação, percebendo que, primeiro, mesmo no final do século XX, no século XXI, a religiosidade é muito importante para as pessoas, impacta a saúde e de um modo geral impacta de um modo positivo. Ou seja: isso deixou de ser uma teoria e passou a ser um dado constatado que está sendo investigado com mais detalhes. (M1).

As teorias do século $\mathrm{XIX}$ de que a religiosidade era o estágio primitivo do ser humano. [...] Freud tinha uma visão muito negativa da religião. A visão dele foi muito dominante.[...] Tinha uma visão extremamente negativa e de um modo geral se imaginava que o religioso era mais neurótico, o religioso era mais reprimido, tinha imaturidade da personalidade, não saberia lidar com as dificuldades da vida por si mesmo por isso que criaria as questões religiosas. Essa visão muito negativa foi totalmente prevalente na grande maioria das vezes no campo da psiquiatria e da psicologia. (M1).

Eu diria que a minha visão é quase que solitária/isolada porque os médicos normalmente separam nitidamente essa questão da espiritualidade com assistência médica [...] porque durante quase um século, desde que Freud escreve as teorias da espiritualidade dizendo que a religião era uma fonte de neurose, passou-se a acreditar que essa vivência é negativa, quando na verdade não tinha nenhuma pesquisa maior, séria. Foi uma visão muito particular de Freud. Isso contaminou, inclusive, toda a área da saúde e é isso que ainda tem, apesar de quase um século depois e de tantos milhares de pesquisas que mostram exatamente o contrário [...] Então quer dizer: o que está acontecendo é uma desinformação dos psiquiatras 
e dos médicos em geral sobre as pesquisas que tratam do impacto da espiritualidade na vida das pessoas. Quer dizer: a partir do momento em que eles tomarem contato com as pesquisas feitas seriamente, publicadas em jornais de alto impacto, são verdadeiras no sentido de que são legítimas, as pessoas vão começar a quebrar as suas armas, os seus preconceitos e entender que isso pode ser um coadjuvante no tratamento. (M13).

$\mathrm{Na}$ verdade, quando esses psiquiatras bi-posicionados contestam o tipo de medicina psiquiátrica colocada em prática, eles a reforçam, pois, como foi alertado por Bourdieu (2006, p. 167), "a ortodoxia necessita da heresia porque a oposição entre uma e outra implica o reconhecimento do interesse que está em jogo, reconhecimento desconhecido [...]". E a Illusio (investimento no jogo) é o acordo no desacordo, é a consideração da importância, do valor do que está no campo apesar do desacordo sobre vários aspectos desse mesmo campo. Assim, participar da illusio seja ela qual for - científica, literária, filosófica ou qualquer outra - é sinônimo de "levar a sério (por vezes a ponto de fazer, também aí, perguntas de vida e morte) os móveis dessa competição os quais, nascidos da lógica do próprio jogo, conferem seriedade ao jogo [...]" (BOURDIEU, 2001, p. 21). Ou seja, é na própria contestação, na busca por inovação que reside a valorização do campo.

Para delimitar o campo legítimo de discussão, há uma cumplicidade entre os adversários que são, dentro do campo, os dominantes e os dominados. Esse tipo de disputa, em vez de enfraquecer, fortalece o campo, o qual se mantém justamente por meio das rivalidades entre os concorrentes. Provavelmente, no campo médico assim como no campo científico de um modo geral, a importância é dada àquilo "que tem chances de ser reconhecido como importante e interessante pelos outros" (IDEM, 1983a, p. 125). Normalmente, os pesquisadores concentram-se em temas que são tidos como sendo os mais vantajosos, pois serão esses que trarão "um lucro simbólico mais importante" (IBIDEM). Dessa forma, ao se debruçar sobre um tema espinhoso e delicado como religião/espiritualidade, o psiquiatra bi-posicionado corre o risco de não ter o seu objeto de análise reconhecido pelos seus paresconcorrentes. Isso faz todo o sentido levando-se em consideração que a "definição do que está em jogo na luta científica faz parte do jogo da luta científica". Nesse jogo, os dominantes são aqueles que estabelecem uma definição da ciência "segundo a qual a realização mais perfeita consiste em ter, ser e fazer aquilo que eles têm, são e fazem" (IBIDEM). 
No entanto, é sabido que, muitas vezes, a não escolha de determinados assuntos para serem pesquisados tem uma conexão com a saturação - relacionada à intensa competição - destes mesmos assuntos e, consequentemente, à diminuição do lucro simbólico a eles relacionados. Tal situação pode conduzir a "uma migração de pesquisadores em direção a novos objetos menos prestigiados, mas em torno dos quais a competição é menos forte" (BOURDIEU, 1983a, p. 125). Nessa perspectiva, a partir da transferência de capital de um espaço dominante para outro considerado inferior dentro do mesmo campo, o detentor de determinado capital científico pode obter maior lucro simbólico. Esse tipo de prática pode ser pensada como uma conversão dentro do campo científico: "As reconversões através das quais somos levados a novos gêneros, a novas disciplinas, a novos objetos etc. são vividas como conversões" (IDEM, 1996b, p. 142). O entendimento neste estudo é de que a conversão pode ser apreciada no sentido de uma brusca mudança, uma ruptura inovadora (independente do sentido positivo ou negativo a ela atribuído) no campo.

Tudo precisa começar com uma mudança de mentalidade dos médicos sobre o assunto. Isso pode ser feito mediante pesquisas concretas, pela promoção de cursos na graduação e na pós-graduação, é o que pensam alguns médicos. Para mudar uma "verdade" construída ao longo dos anos é preciso "munir-se de razão", o campo científico é um jogo que exige acúmulo de capital.

As pesquisas hoje em dia têm mostrado cada vez mais o impacto que a espiritualidade tem na saúde das pessoas. Na [sic] medida em que essas pesquisas forem divulgadas ou trabalhadas e mesmo educados os públicos que trabalham dentro do hospital, sejam eles médicos, enfermeiros, psicólogos, é uma tendência natural que a espiritualidade venha a tomar um espaço, vamos dizer assim, contínuo e permanente dentro dos hospitais. Não só privados como públicos também. (M13).

Ao alcançar um alto grau de autonomia, só é possível triunfar, segundo Bourdieu (2004b, p. 46), a partir do momento em que há uma conformação "às leis imanentes do campo" ao qual se pertence; ou seja, faz se necessário que, além de haver o reconhecimento da "verdade como valor", haja o respeito pelos "cânones metodológicos que definem a racionalidade no momento considerado", bem como o investimento nas lutas de concorrência de "todos os instrumentos específicos 
acumulados no decorrer das lutas anteriores". Ou seja, para que as novas propostas alcancem sucesso, elas deverão inevitavelmente estar em sintonia com o jogo do campo científico (seja no que diz respeito aos seus objetivos derradeiros, seja em relação à utilização do seu instrumental peculiar já acumulado).

No final das contas, quem estará apto a dizer a verdade? No universo científico ocorre uma luta para saber quem "está realmente (ou particularmente) fundamentado para dizer a verdade [...] sobre o mundo social (e sobre o mundo físico)" (BOURDIEU, 2004b, p. 116).

Antes, para ser cientista, não tinha que ser o cientista. O cara podia ser padre, o cara podia ser um comerciante e participar da sociedade científica acadêmica e começou um grupo mais profissional que: "Eu sou cientista e o resto não é". Aí tem uma briga ali e de qualquer forma começa a acontecer, realmente, uma ruptura entre a ciência e religiosidade, uma briga efetiva. Isso permeia boa parte do século XX. Então eu acho que a nossa formação começou a ser a partir daí. (M1).

É muito mais complexo do que aparenta ser, pois, segundo Bourdieu, não se trata "simplesmente de dizer a verdade desse mundo, mas também de dizer que ele (é) o lugar de uma luta para dizer a verdade desse mundo" (IBIDEM, p. 117). O fato é que somente quem está engajado no mesmo jogo, no caso o jogo científico, pode avaliar os méritos ou descréditos de uma obra.

\subsubsection{NEPER/ProSER}

\section{• Histórico e posicionamento}

O NEPER foi fundado tomando como base a nova classe do DSM-IV ${ }^{163}$ (Diagnostic and Statical Manual of Mental Disorders) e levando em consideração a grande diversidade religiosa do Brasil associada à falta de reflexão quanto a essa

163 Segundo Almeida et al. (2000, aspas do autor), a Associação Psiquiátrica Americana deu um passo importante ao inserir no DSM-IV a categoria diagnóstica "Problemas Espirituais e Religiosos", a qual "foi incluída no eixo I, no item 'Outras condições que podem ser um foco de atenção clínica"'. 
questão por parte da medicina (ALMEIDA et al., 2000). O objetivo desse núcleo é voltar-se para as questões religiosas e espirituais a partir de um enfoque científico da moderna psiquiatria, desvinculado de qualquer corrente filosófica ou religiosa. Outra proposta importante de seus integrantes é fazer com que o NEPER auxilie na sensibilização da psiquiatria no que diz respeito à produção e difusão de conhecimento relacionado aos problemas espirituais e religiosos (IBIDEM) ${ }^{164}$. Os médicos que estão atentos à importância da variável religiosa no tratamento da doença chamam a atenção dos especialistas de sua área para as seguintes questões:

- A religião, uma variável que influencia a saúde mental, está sendo negligenciada pela psiquiatria nos seus estudos e programas de tratamento e prevenção.

- É necessário que o psiquiatra esteja familiarizado com a literatura sobre religião e conheça a religiosidade de sua clientela, para saber como utilizá-la clinicamente. (LOTUFO-NETO, 1997, p. 257).

Os especialistas do NEPER que investem no sentido do diálogo entre psiquiatria e religião têm como intenção defender a importância de uma atuação mais sensível por parte da psiquiatria, pois, segundo acreditam, as variáveis religiosa e espiritual fazem parte dos fatores essenciais na organização da experiência humana, das crenças, dos valores, dos padrões de comportamento e de doença (ALMEIDA et al, 2000). Por conta de tal fato, eles defendem uma postura mais adequada em relação aos pacientes e a suas respectivas crenças, no sentido de maior atenção e respeito aos credos que orientam suas vidas. Dessa forma, e somente assim, os médicos poderão utilizar verdadeiramente seus conhecimentos terapêuticos para ajudá-los a levar uma vida religiosa plena (LOTUFO-NETO, 1997). Esse é um posicionamento específico dos psiquiatras que consideram importante a religião para a vida dos pacientes e que por isso se debruçam sobre essa questão, seja no sentido de aglutinar adeptos, seja no sentido de produzir pesquisas que fortaleçam essa perspectiva.

Esses médicos adeptos de uma sensibilização para as questões religiosas afirmam, entretanto, que normalmente o que se percebe na prática médica, de um

164 Segundo acreditam esses médicos, dar atenção à questão da espitritualidade e pesquisar sobre ela é importante para evitar erros de diagnóstico, pois é possível confundir-se a espiritualidade do doente com a doença mental. Segundo esse ponto de vista, existem problemas espirituais e religiosos que, entretanto, não são problemas mentais. 
modo geral, é uma tendência à não valorização das dimensões religiosa e espiritual da vida, tendo em vista que as tendências positivistas da psiquiatria rechaçam qualquer tipo de subjetivismo (LOTUFO-NETO, 1997, p. 28). Na verdade, a medicina de um modo geral se constitui enquanto ciência objetiva "pela libertação e pela autonomização do biomédico" (LAPLANTINE, 2004, p. 225) à custa de uma ruptura com o social, particularmente o rompimento com um aspecto do social que é o religioso (IBIDEM). Obviamente que, se a ciência médica contemporânea progride dando continuidade a essa atitude (sob a forma de rechaço dos aspectos mágicoreligiosos enquanto variável importante na vida do paciente), é "ao preço de uma descontextualização cultural da doença e de uma ocultação da ligação do doente com sua sociedade" (IBIDEM). Ou seja, tomar como condição para a autonomia da medicina o repúdio do aspecto social é dar um passo em direção à fragmentação do ser humano-doente.

Nessa perspectiva, por serem, de um modo geral, menos religiosos, os psiquiatras acabam não dando importância ao significado que a religião pode ter na vida dos pacientes. Quando esses profissionais veem alguma importância na religião é para explorá-la no seu aspecto negativo, ou seja, "não há treinamento para que os profissionais de saúde mental aprendam a lidar com variáveis religiosas (IBIDEM, p. 186). Esse é o posicionamento particular de alguns psiquiatras que consideram o aspecto religioso relevante. Todavia, é necessário ainda levar em conta o posicionamento dos médicos de um modo geral, para que assim seja possível comparar os diferentes pontos de vista.

Os ministros religiosos do HCFMUSP evidenciam como a questão da presença religiosa no hospital é tratada atualmente. Acreditam que exista um conflito sim, já que pessoas ocupantes de nível de comando veem a sua presença como irrelevante, desnecessária e consideram um absurdo despender recursos para mantê-los ali (AR3). Nesse descaso, estão presentes relações de poder entre campos de atuação distintos que não abrem mão de sua independência e autonomia. O fato é que, atualmente, está nas mãos da medicina o controle do saber erudito de curar (OLIVEIRA, 1985, p. 80) e, por conta desse monopólio, ela tem o poder de desqualificar aquilo que não consiga explicar (IBIDEM).

Entretanto, apesar da propalada indiferença dos médicos em relação a aspectos religiosos do paciente, o IPQ apresenta-se de um modo um pouco distinto, 
na medida em que esforça-se por estabelecer aproximações e diálogos. Isso se deve à existência daqueles profissionais que dentro do ambiente hospitalar da psiquiatria fazem a ponte entre as partes ${ }^{165}:$ :[...] há pessoas (no IPQ) que são intensamente religiosas, intensamente pessoas de fé, pessoas que sabem exatamente o propósito da nossa presença aqui dentro, a função nossa aqui dentro, valorizam a nossa presença como ela tem que ser valorizada" (AR3). Em estudo feito recentemente, Puttini (2004) discorre sobre o que ele chama de "agente híbrido", ou seja, o sujeito que faz a ponte entre medicina e religião dentro do hospital. É necessário lembrar, entretanto, que também foi decisivo o apoio por parte da diretoria do IPQ, o apoio dos titulares que aparecem, por sua vez, como intercessores nesse processo.

A gente teve, realmente, sempre, um grande apoio da direção do Instituto de Psiquiatria, dos titulares que nunca criaram problemas para o grupo e atualmente estão abrindo cada vez mais espaço: desde a revista de Psiquiatria Clínica sobre o tema, a primeira revista em língua portuguesa, médica, só sobre esse tema; a disciplina na pós-graduação de metodologia de pesquisa em espiritualidade e saúde. (M1).

Se, de um lado, é denunciada e criticada a subestimação da religião por alguns profissionais da área médica, por outro lado, existe atualmente uma relação de aproximação (não menos evidente) que pode ser visualizada por meio da tentativa de colocar em diálogo religião e psiquiatria no IPQ do HCFMUSP. Ou seja, se, por um lado, uma parcela de profissionais - veneradores que são do campo científico - procura manter "a ilusão de uma ruptura entre a doença e o social" (LAPLANTINE, 2004, p. 225); por outro lado, existem aqueles que veem na religião, enquanto pensamento totalizante, a possibilidade de "tomar consciência daquilo que nos é oculto pelo pensamento científico: [...] a relação com o social" (IBIDEM). Nessa perspectiva, a religião representaria o elo de contato com o social mais amplo.

A ideia inicial do NEPER era trazer pesquisadores da área e aprofundar a discussão sobre a temática saúde/espiritualidade - "a gente fechou para

165 Papel desempenhado claramente pelos psiquiatras bi-posicionados, de um lado, e não tão abertamente pelos neutros/ambíguos, de outro lado. Estes últimos representam a maleabilidade na atuação dos psiquiatras: nem tanto o rigor do mono-posicionado, nem tanto a religiosidade como bandeira, no caso dos bi-posicionados. 
pesquisadores que estão, realmente, fazendo mestrado, doutorado ou que já fizeram ou que têm interesse nessa área, esse foi o foco" (M1) - e a partir daí, a intenção passou a ser, então, a de se formar multiplicadores/formadores nessa área (M1). Posteriormente, com o intuito de ampliar os objetivos deste núcleo de pesquisa houve a mudança do nome NEPER para ProSER ${ }^{166}$. Tal alteração deveu-se, entre outras coisas, à necessidade de incluir a denominação "programa" em todos os grupos de pesquisa existentes no Instituto. A partir daí a coordenação do NEPER abriu a possibilidade de que os integrantes pensassem um nome, este deveria refletir as reais intenções do grupo que era a busca pela interface entre saúde, espiritualidade e religiosidade. A decisão final foi ProSER (Programa de Saúde, Espiritualidade e Religiosidade). Mediante esse novo nome, as intenções deveriam extrapolar àquelas do NEPER que se restringiam apenas à pesquisa. Os objetivos, a partir de então, iriam também ao encontro do ensino e da assistência aos grupos religiosos que atuam no IPQ.

Além de ser um grupo de estudo e fomento de pesquisa, a gente tem ideia também de criar cursos. Já existe um curso, inclusive, que está sendo feito, que é um curso de espiritualidade na psicoterapia e de prestar assistência também. Assistência essa que ainda não está em curso, mas existe a ideia de desenvolver nesse programa ${ }^{167}$ assistência também. Então, aí, nós teríamos o tripé: pesquisa, ensino e assistência. Então, a mudança do nome tem a ver com isso. Tem a ver com essa necessidade do Instituto e tem a ver com essa ideia de ampliação da dimensão do grupo. (M27).

O ProSER ${ }^{168}$ é aberto à participação desde que se faça o contato inicial com a coordenação. No entanto, o fato de frequentar as reuniões não garante 0 pertencimento ao grupo ou ao Instituto como pesquisador. Existem os trâmites

\footnotetext{
${ }^{166} \mathrm{O}$ desligamento - por falta de disponibilidade - de pessoas que encabeçavam o NEPER e a falta de substitutos para a função fizeram com que o grupo ficasse por volta de três anos sem atividades, mantendo, entretanto, durante esse período "alguns esboços de tentativas de retomar. [...] Havia uma comunicação muito superficial e uma tentativa de querer organizar, mas não aconteceu nada a não ser uma ou outra reunião com ideias de retomar". (M27). Não houve dificuldades na retomada - que começou, de fato, em início de 2008 -, pois o referido grupo já tinha espaço garantido, contando com o apoio de alguns profissionais do Instituto anteriormente envolvidos no projeto.

${ }^{167}$ Importante frisar que esse programa de assistência encabeçado pelo ProSER encontra-se em fase de elaboração e quase implementação. As informações obtidas até o momento da finalização deste trabalho dizem respeito apenas aos encaminhamentos realizados para o desenvolvimento do programa.

${ }_{168}$ Consultar no Apêndice desta tese o quadro com a descrição dos temas abordados nas reuniões do ProSER.
} 
burocráticos que devem ser respeitados ${ }^{169}$ : para compor o quadro de pesquisadores não é necessário estar vinculado à pós-graduação com um projeto de mestrado ou doutorado; porém, exige-se que o projeto do interessado tenha passado pelo crivo do departamento de Psiquiatria. Para ser encaminhado ao departamento via ProSER, o responsável deste programa deve estar de acordo com o projeto. Depois de avaliado no departamento, o projeto precisa ser aprovado pela Comissão de Ética da faculdade. Após passar por todo esse processo é que se pode ser considerado pesquisador. Esse é o procedimento para todos os grupos de pesquisa do IPQ.

O objetivo da assistência proporcionada pelo ProSER é no sentido de acompanhar as atividades de assistência espiritual, criando para isso programas ${ }^{170}$. Inicialmente seria algo como um capelanato, o qual não necessariamente está vinculado a uma religião: "Inclusive deve ser uma pessoa de mente aberta que propicie que diversas denominações religiosas ou diversas necessidades espirituais dos pacientes sejam acolhidas" (M27). A perspectiva aqui é de acolhimento de demandas as mais diversas no âmbito do universo da religiosidade/espiritualidade.

O ProSER não vai fazer assistência espiritual. Na realidade a ideia é que a assistência espiritual seja feita pelos agentes religiosos: pastores, padres, espíritas, budistas, quem quer que seja sob a coordenação do ProSER, acompanhando/participando dessa atividade. [Este acompanhamento dar-se-ia] criando programas. $\mathrm{Na}$ realidade, o PROSER pretende, na assistência, criar programas onde as necessidades religiosas dos pacientes possam ser acolhidas. Vamos supor que o paciente tenha necessidade de receber a visita de um agente religioso da religião a que ele pertence e tudo, que existam programas que permitam/organizem esse tipo de coisa. No início seria uma espécie de capelanato. O capelão é um sujeito que faz isso, é responsável. Nos EUA, por exemplo, são contratados funcionários para esse fim. (M27).

\footnotetext{
${ }^{169}$ Segundo M27, em reposta à indagação da pesquisadora quanto a alguns desentendimentos, entre membros, na retomada do NEPER: "Tinham algumas pessoas que acharam que podiam fazer algumas coisas independentes no grupo e isso gerou, talvez, esses conflitos aí [que você está mencionando]" (M27).

${ }^{170}$ Interessante notar que a ideia de criação de um programa de assistência religiosa, ainda que tenha a intenção de se estender a todo o complexo do HCFMUSP, eclodiu do Instituto de Psiquiatria e não de outros Institutos/faculdades: "Eu acho que o ProSER é uma semente que pretende produzir bons frutos. Então, inicialmente, a gente vai estar meio focado aqui no IPQ, no complexo HC, mas à medida que esses programas forem implementados, testados e desenvolvidos, eles podem ser expandidos para outras instituições. Esse é o objetivo" (M27). Ou seja, o IPQ - assim como o grupo de psiquiatras bi-posicionados é visto no seu interior - promove uma atitude inovadora no complexo do HCFMUSP. Desse modo, a inflexão deve ser vista não somente no interior do Instituto de Psiquiatria, mas no interior do hospital como um todo.
} 
A princípio a ideia é fazer um mapeamento das necessidades espirituais dos pacientes para então criar programas que facilitem a ação dos religiosos. Com relação aos profissionais de saúde, a intenção é treiná-los para que possam diagnosticar tais necessidades e acolhê-las. A expectativa não é que esse profissional de saúde conceda assistência espiritual, mas sim que ele "seja um acolhedor" da necessidade religiosa do paciente, no sentido de valorizá-la e saber dar um encaminhamento para que essa necessidade seja atingida/atendida de algum modo (M27).

O profissional de saúde pode dar iniciativa no sentido de perguntar sobre a espiritualidade do paciente, mas para isso ele deve ser treinado (M27) - "nos EUA, por exemplo, eles dão treinamento para o médico já na faculdade de como perguntar para o paciente, por exemplo, se ele tem alguma crença religiosa" (M27). Esse treinamento poderá ajudar no sentido de "criar conforto" num diálogo que venha a se estabelecer entre o profissional de saúde e o paciente, os quais podem sentir-se constrangidos.

$\mathrm{Na}$ verdade, existem o preconceito e o desconforto, este gerado pelo primeiro. Os dois por falta de treinamento. Ou, ainda que não haja preconceito, o profissional não possui conhecimento de como lidar com uma situação que envolva religião/religiosidade. Aí reside a importância do treinamento: preparar para trabalhar com esse tipo de questão sem transformá-la "em motivo de angústia/ansiedade/problema durante o relacionamento" (M27). O argumento utilizado por alguns psiquiatras de que fazer um levantamento das necessidades espirituais do paciente seria uma sobrecarga a mais é colocado em discussão pelos que acham que quando há o treinamento para fazer uma condução suave dessas necessidades elas não irão sobrecarregar (M27).

A grande questão é ter uma equipe de profissionais que seja capaz de realizar esse trabalho e para que isso ocorra é imprescindível, acredita-se, que haja o treinamento adequado: "Na hora que você tem uma equipe de saúde treinada para reconhecer as necessidades/acolhê-las e saber encaminhá-las eu acho que grande parte do problema está atendida" (M27). Deve haver treinamento dos dois lados, tanto dos agentes de saúde quanto dos religiosos. Estes últimos recebem treinamento para atuar no complexo do HC e são chamados de leigos e, conforme acredita M27, são treinados pelo CARE. Eles recebem treinamento e orientações de 
"como devem se comportar, quais são os limites de atuação deles, não buscar confrontação/substituição, estimular o paciente a não seguir um procedimento em função de uma crença e tudo, mas fazer uma coisa de associação" (M27). Num primeiro momento, a ideia é fazer um apanhado das necessidades religiosas dos pacientes e ajudar no sentido da criação de programas para atender essas necessidades. Se, porventura, perceber-se a necessidade, no momento de desenhar estes programas, de treinar o agente religioso, os psiquiatras poderão então participar nesse sentido.

O fato de não haver um programa "mais organizado" (M27) $)^{171}$ de atendimento religioso no sentido de que "a coisa é feita de uma forma ainda muito solta" (M27) faz com que até mesmo o trabalho religioso (de padres, pastores) já existente no hospital seja comprometido, sendo "mal interpretado pelo paciente"172 (M27). A presença do padre associada à morte iminente (e à extrema-unção) é resultado da falta de um programa voltado para isso. Semelhante questão é constatada por M27, que já ouviu relatos nesse sentido: "Um dos padres já mencionou em uma apresentação que ele chega lá e o paciente fala: 'Não, doutor, mas eu vou morrer? Não preciso de padre'”. Quando não se tem um programa que organize o atendimento, corre-se o risco de más interpretações e até mesmo da interrupção de trabalhos anteriormente iniciados: "O coral não tem ocorrido, foi suspenso porque falta um programa que organize/direcione. Então fica muito da iniciativa de certas pessoas e esta iniciativa, desde que não é sustentada por um programa, ela ocorre, às vezes e às vezes não ocorre" (M27). Além do mais, complica até mesmo a entrada dos agentes religiosos visto que, sem um programa por trás, a autorização para ter acesso ao espaço é dificultada: "Se você tem um programa, essa autorização vai estar implícita no programa" (M27). Até mesmo os padres e pastores dependem de autorização. Isso porque existe uma complexidade maior do IPQ em relação às demais especialidades do HCFMUSP, pois lá "existem

\footnotetext{
171 Segundo M27, o programa de atendimento é pensado nos moldes de uma abertura para os diferentes tipos de religiosidades. Normalmente cada hospital, dependendo da sua característica ou disponibilidade, oferece determinado tipo de atendimento. Existem até mesmo hospitais que concebem um espaço para meditação e oração com música ambiente.

172 Como apontado em outra parte desta tese, onde é feita a abordagem sobre a capelania religiosa no HCFMUSP (Capítulo 2 da parte I).
} 
os delírios místicos" (M27) com os quais deve haver cautela, visto que uma prática religiosa pode alimentá-los $(\mathrm{M} 27)^{173}$.

Tem havido tentativas incipientes no sentido da criação de programas relacionando saúde e espiritualidade em outras partes do Brasil ${ }^{174}$ (na direção de começar a estudar o assunto, fazer pesquisa para levantar dados capazes de sustentar ações que tenham evidências de eficácia na relação de saúde). No fundo, acredita-se que "sempre teve gente buscando essa interface. É que às vezes essa situação foi vivida com muito conflito" (M27). Ao contrário de outros tempos, onde a atuação não era oficializada, hoje se tem o espaço garantido para isso, uma abertura maior para falar sobre a questão. No próprio IPQ houve épocas em que tratar desse assunto não era permitido. Atualmente a situação se reverteu e "não só é permitido como o Instituto acolheu o grupo, incentivou até a formação do grupo e tudo. Isso é uma mudança. Mudança paradigmática, eu diria” (M27). Realmente a curvatura realizada no modelo psiquiátrico se sobressai pela sua ousadia, por não se intimidar com as possíveis dificuldades no que diz respeito à mudança de regras há muito estabelecidas.

O ProSER não está vinculado diretamente a alguma religião, ainda que se possa perceber uma participação representativa de espíritas - o que talvez se explique pelo fato de o "espiritismo valorizar muito essa associação/interface [entre ciência e religião]" (M27). Há abertura para qualquer pessoa que queira fazer parte independente da sua religiosidade, bem como independente da sua especialidade de agente de saúde (médico, enfermeiro, dentista, psicólogo, etc), pois a ideia é ser um grupo multidisciplinar. Segundo M27, há uma proporção grande de pessoas no grupo que não segue nenhuma religião, elas "são interessadas não no aspecto

\footnotetext{
${ }^{173}$ Pode-se notar que, por vezes, até os psiquiatras bi-posicionados fazem alusão à possibilidade do delírio místico por parte do paciente (a questão do delírio místico/religioso será abordada detalhadamente no capítulo 5). Ainda que seja um revolucionário no que tange a questão de perceber o paciente inserido na sua cultura, o psiquiatra bi-posicionado não se aparta das características básicas defendidas pelos seus pares; ou seja, por mais que efetue um rompimento radical com a postura médica oficial, "ele sabe que não pode, não importa o que pense ou faça, deixar de agir e pensar em termos de medicina. Cada palavra que ele pronuncia é, quer ele queira ou não, uma palavra de médico" (DUHAMEL, 1946 apud LAPLANTINE, 2004). Em outros termos, o médico está marcado pelo fervor (religioso) à medicina, o que acaba por mostrar que assim como o empreendimento eclesiástico, o empreendimento médico é indelével (IBIDEM).

174 Além do NEPER/ProSER, outros grupos em universidades desenvolvem pesquisas na área de saúde e espiritualidade: Laboratório sobre Saúde, Espiritualidade e Religiosidade (LASER) da UNICAMP, Liga Acadêmica de Saúde e Espiritualidade (LIASE) da Universidade Federal de Goiás; Núcleo de Espiritualidade e Saúde (NUPES) da Universidade Federal de Juiz de Fora; Núcleo de Estudos da Religião (NER) da Universidade de Brasília e Núcleo Interdisciplinar de Estudos Transdisciplinares sobre Espiritualidade (NIETE) da Universidade Federal do Rio Grande do Sul.
} 
religiosidade, mas no aspecto espiritualidade" (M27). A despeito disso, a tendência é "como qualquer grupo de estudo que está começando, serem pessoas interessadas no tema que tenham alguma crença religiosa ou espiritual” (M27).

As opções religiosas do CARE são consideradas restritas, com atuação católica e protestante, e muito recentemente, a participação dos espíritas ${ }^{175}$, agora oficializada. A entrada dos espíritas não aconteceu sem que houvesse impasses e ela concretizou-se mais devido a características pessoais do candidato à vaga - o qual possuía facilidade em se relacionar com os demais membros - do que pela importância dada ao espiritismo em si. Entretanto, a rigidez das denominações religiosas e de seus representantes parece dar lugar à flexibilidade, visto que se acredita ser "o mundo de hoje mais polivalente, multicultural, mais aberto" (M27). Tal abertura acontece no que o entrevistado chama de "bordas" do religioso instituído.

Todas as religiões, no seu núcleo duro, tendem a ser mais puristas, tendem a rejeitar as outras religiões/denominações, mas nas bordas há mais comunicação, permitindo que as pessoas possam transitar. A tendência, eu acho que é da maioria ficar mesmo nas bordas. Evidente que sempre vai ter algumas pessoas que vão ficar no núcleo até para garantir a integridade dos fundamentos daquilo ${ }^{176}$. Por enquanto, pelo menos. Pode ser que no futuro essas fronteiras se dissolvam e haja uma interação maior e os movimentos sejam mais ecumênicos [...]. Eu acho que ainda há resistências a serem vencidas. Há barreiras. Por desconhecimento, por estruturação... 0 fenômeno religioso é um fenômeno muito dinâmico. (M27).

Sem essa flexibilidade anda-se em direção à intolerância, ao fanatismo religioso, os quais são considerados aspectos negativos da religiosidade. Até mesmo no ProSER, as pessoas chegam querendo demarcar uma postura religiosa de a favor ou contra, e elas têm cedido à comunicação, à troca de experiências e ideias, a um compartilhamento de algo em comum - "essas bordas onde a questão de ficar demarcando está perdendo força" (M27). O que tem tido ênfase é a ideia do ProSER enquanto representante de um projeto incipiente, por intermédio do qual todos podem associar-se com vistas ao fortalecimento no combate a inimigos como a ignorância, o preconceito, a rigidez (M27).

\footnotetext{
${ }^{175}$ Segundo M27, houve recentemente a aprovação pelo superintendente do hospital para que um membro do ProSER, que é espírita, seja o representante da comunidade espírita no CARE.

${ }^{176}$ Mediante esse relato sobre o campo religioso, o psiquiatra bi-posicionado parece dar vazão à sua própria situação de deslocamento do núcleo duro do mundo científico em direção a algo mais maleável que permite o agraciamento de questões aparentemente exteriores e estranhas à ciência.
} 
Toda religião que for intolerante e que pregar/incentivar a intolerância religiosa, vai atuar negativamente na saúde [...] Você tem que ter tolerância. Passar seu recado, divulgar suas ideias religiosas e tudo, mas deixar a opção de escolha. Isto é essencial na saúde: precisa ter opção, poder escolher, poder ter diversidade. (M27).

Acredita-se que esse movimento de atuação conjunta ou de participação de outras religiões não esteja acontecendo de forma impositiva, mas de forma natural e gradual. Aos poucos, tudo vai caminhando inevitavelmente para a acomodação da diversidade e do trabalho conjunto (no que diz respeito tanto ao campo religioso quanto ao campo psiquiátrico). 


\section{MODELO RELIGIOSO ATUAL}

\subsection{POSICIONAMENTO DO RELIGIOSO NO CAMPO RELIGIOSO}

De modo análogo à elaboração realizada em relação aos psiquiatras, a intenção aqui é também a de revelar os posicionamentos dos religiosos, exibindo assim as qualidades constitutivas da postura defendida por cada um. Dois modos de se posicionar distintos são apresentados no interior do campo religioso: o racionalizado e o "magicizado" 177 .

O racionalizado assim é definido pela presença de caracteres secularizados, com traços que se aproximam mais do discurso científico. Já o "magicizado" possui qualidades que o distanciam do primeiro no sentido de contradizer aspectos de uma religiosidade intelectualizada e eticizada (adequada ao ambiente científico), fazendo uso de discursos voltados para a cura milagrosa ${ }^{178}$, o poder de Deus em detrimento do conhecimento do psiquiatra.

O quadro a seguir apresenta mais detalhadamente quais os informantes compõem os diferentes posicionamentos.

\footnotetext{
${ }^{177}$ Parece conveniente esclarecer que ao utilizar o termo "magicizado" busca-se fazer referência a uma atitude menos racionalizada, tendendo a ser magicizada. Vale-se aqui de tais termos mais como um recurso para contrapor atitudes que se contradizem do que para classificar e enquadrar pura e simplesmente os sujeitos em categorias como magia e religião. Os voluntários religiosos chegam bem perto de uma mentalidade mais magicizada. Enquanto as autoridades religiosas ficam no discurso mais racionalizado (da cura científica), os voluntários dão ênfase à cura obtida tal como se fosse um milagre (mesmo que se obtenha mediante a súplica a Deus, a cura é um elemento muito importante dentro do universo daqueles religiosos).

${ }_{178} \mathrm{O}$ milagre é um elemento genérico da religião, contrapô-lo à racionalização seria um equívoco, porém a atitude mais presa à cura milagrosa opõe-se de certa forma ao caráter mais racionalizado da religião. A cura existe tanto dentro da religião como da magia, o meio de chegar a ela é que é diverso em ambas. A importância da cura não é central numa religião mais racionalizada, a qual normalmente foge dessa questão (pensando em termos de protestantismo clássico, o qual dá ênfase mais à ética do que propriamente à súplica ao Deus no sentido de obter a cura e a salvação; embora estas existam também, é uma questão de ênfase). Dentro do contexto protestante histórico, o milagre é algo que não existe no cotidiano da religião. Já no catolicismo ele existe, persiste. Até mesmo porque, no sentido weberiano, o protestantismo é uma religião mais racionalizada do que o catolicismo. Neste, o milagre é realizado por um ser sobrenatural a quem se intercede. Ainda que haja muitos contextos em que os santos são manipulados magicamente, a ideia de uma cura milagrosa, de se suplicar ao santo para que ele realize o milagre está dentro da essência do universo católico; nas fimbrias mais populares do catolicismo, ele pode quase chegar a uma espécie de religião magicizada.
} 


\begin{tabular}{|c|c|c|c|}
\hline \multicolumn{2}{|c|}{ Racionalizado } & \multicolumn{2}{c|}{ "Magicizado" } \\
\hline $\begin{array}{c}\text { Autoridades } \\
\text { Religiosas }\end{array}$ & $\begin{array}{c}\text { Voluntários } \\
\text { Religiosos }\end{array}$ & $\begin{array}{c}\text { Autoridades } \\
\text { Religiosas }\end{array}$ & $\begin{array}{c}\text { Voluntários } \\
\text { Religiosos }\end{array}$ \\
\hline AR1 & VR4 & & VR1 \\
\hline AR2 & VR6 & & VR2 \\
\hline AR3 & VR13 & & VR3 \\
\hline & & & VR5 \\
\hline & & & VR7 \\
\hline & & & VR8 \\
\hline & & & VR9 \\
\hline & & & VR10 \\
\hline & & & VR11 \\
\hline
\end{tabular}

Quadro 3 - Posicionamento no campo religioso

\subsubsection{Racionalizado}

A ciência contentou-se em estender a mão à teologia, - com tal segurança, que a teologia não soube enfim se devia crer em si ou na outra. (O Alienista, Machado de Assis).

Apesar das diferenças relativas a pertenças a campos distintos, os religiosos (padres, pastores) que são admitidos no Hospital das Clínicas são aqueles que possuem uma mentalidade mais secularizada. Talvez, resida nisso o fato de eles serem aceitos e de aceitarem o discurso científico.

No curso ministrado aos voluntários evangélicos, os formadores ensinam como deve ser realizada a aproximação do paciente, o que se pode e o que não se pode falar. Apesar de a Bíblia frequentemente conter relatos sobre curas realizadas (AR3), o voluntário é instruído a não fazer esse tipo de promessa. É algo perigoso e que é proibido ali dentro. Ainda que a cura seja algo considerado possível de acontecer, segundo AR3, não é adequado naquele ambiente realizar esse tipo de propaganda. Há os que parecem entender bem como funciona o princípio de contato com os pacientes ensinado pelas autoridades religiosas: deve haver cuidado com o que se fala; não prometer cura; não prometer milagres; não fazer proselitismo (VR4). 
Acima de tudo, não se deve dar falsas esperanças aos pacientes (VR4, VR13) ${ }^{179}$. Segundo VR13, nas visitas "não se fala em Deus, não se promete nada de Deus".

A despeito das formações proporcionadas aos voluntários é difícil saber se estão fazendo o que foi ensinado, se cumprem a regra que se resume a primeiramente atender o paciente no âmbito físico, sendo que "a questão espiritual/religiosa torna-se, ainda que fundamental/substantiva, um pouco acessória" (AR3). No interior de um grupo bastante heterogêneo não é possível responder por todos (VR6), entretanto, acredita-se que eles cumpram as orientações, pelo menos é a impressão que as autoridades têm quando fazem uma atividade fiscalizatória (AR3).

A importância da religião pode variar, pois tudo é uma questão de como as pessoas percebem, é uma questão de fé. Além disso, existem novas tendências no modo de encará-la. Atualmente predomina uma percepção diferente. Segundo AR1, "não existe uma verdade absoluta", é necessário responder conforme a necessidade de cada um, "de acordo com aquilo que a pessoa te dá". Normalmente, "o mal da religião" é, baseada no pensamento maniqueísta, acreditar que está com a razão em oposição aos que estão errados ${ }^{180}$. Por isso, de acordo com AR1, não é necessário ao médico crer em algo para obter sucesso, tanto que o profissional ateu realiza uma cirurgia e tem o mesmo sucesso que o cristão ou o que tem fé. Resumindo: "A manga tem o mesmo sabor para o ateu e para o cristão" (AR1). O caráter de santidade, de doação ao próximo não deve ser visto como exclusividade da pessoa que é religiosa - por exemplo, do capelão que tem formação específica para tais questões. Ao contrário, existem pessoas que, independente de posicionamentos religiosos ou de formação nesse sentido, são "bem formadas subjetivamente" e perfeitamente cabíveis ao contexto terapêutico de um hospital (AR3).

As novas tendências, o novo modo de encarar os diferentes tipos de ofertas e as demandas religiosas diversas diz muito de um campo religioso autônomo. Este

\footnotetext{
${ }^{179}$ A respeito disso, VR4 comenta o caso, de que tomou conhecimento, de evangélicas que faziam visita e disseram ao paciente: "Uma disse assim: 'Sai dessa cama. Caminha'. A doente levantou o cobertor, estava sem as duas pernas. Que choque! Choque pra quem disse: 'Caminha, anda' e choque para a doente porque é ignorância. A gente não sabe". (VR4).

${ }^{180}$ AR1 acredita que tudo o que contribui para o bem-estar da pessoa é importante. Entretanto, atenta para a questão de que o grande problema é a rigidez, o radicalismo (não só de religiosos, mas de médicos também): "A gente vê algumas religiões fundamentalistas que pensam que religião não precisa de médico. Ou o contrário. Médico que pensa que o paciente não precisa de religião, não precisa de fé" (AR1).
} 
se movimenta em função justamente, de um lado, das "relações de concorrência que opõem os diferentes especialistas no interior do campo religioso" (BOURDIEU, 1999, p. 50) e, de outro lado, das "relações de transação que se estabelecem, com base em interesses diferentes, entre os especialistas e os leigos” (IBIDEM). Aí está a dinâmica a partir da qual se move o campo religioso.

No caminho da religião racionalizada, não há espaço para colocar em dúvida o papel desempenhado por cada domínio, existem questões que a religião não explica no caso das doenças mentais, mas a maioria pode ser perfeitamente explicada pela psiquiatria sem a interferência religiosa. Entretanto, o conflito surge, por vezes, em momentos em que a medicina diagnostica como patologia mental e a religião confronta afirmando tratar-se de "coisa demoníaca" (AR1). Conflito antigo que se fez presente a partir do momento em que "a teologia se meteu em um lugar que era um campo da ciência: quem tem que explicar se é possessão, se é ataque epiléptico, se é distúrbio mental não é a teologia, é a medicina"181. Nesse sentido, o depoente afirma: "Eu estou mais do lado da medicina" (AR1).

Faz-se referência a uma "religião saudável" $(A R 1)^{182}$ para denotar o que se espera de uma religião verdadeiramente voltada para os aspectos de um agir religioso que despreza o fanatismo, o exagero, o proselitismo, estes característicos de uma "religião doentia" (AR1). Nesse sentido não é para todos que a religião faz bem, "para muitos religião faz mal à saúde" (AR1). Seguindo os rastros da divisão normal versus patológico, tem-se o limite entre religião saudável e religião patológica (ou doentia). Neste último caso, considera-se que a religião é prejudicial. Além de certas religiões não propiciarem um comportamento saudável, alguns sujeitos, mesmo dentro daquelas que são saudáveis, não conseguem elaborar os conceitos de forma sadia, descambam para o fanatismo, para o repúdio da vida no mundo: "Você vê algumas coisas doentias. Então, o cara que tem que se confessar todo dia. Espera aí. Se você acredita que Deus é amor... eu não sei, tem religião que, para muita gente, faz mal" (AR1). Assim, para evitar a generalização de que toda religiosidade é prejudicial ou - como creditam a Freud - que toda religião é fonte de

\footnotetext{
181 AR1 acredita que a maioria dos casos de possessão demoníaca são, na realidade, problemas mentais (AR1).

182 Trata-se de uma religião/religiosidade considerada tanto pelos psiquiatras bi-posicionados quanto pelos religiosos como "protetora da doença mental". M13, por exemplo, afirma haver pesquisas que mostram os "efeitos benéficos entre a vivência de uma espiritualidade saudável e uma melhora na saúde das pessoas" (M13).
} 
neurose, sabiamente (tanto religiosos racionalizados quanto psiquiatras biposicionados) fazem referência ao par religião-saudável/religião-doentia.

Uma proposta religiosa de nível mais intelectualizado, racionalizado, entre outras coisas, não visa conceder milagres, nem realizar operações mágicas. Os religiosos adeptos de tal postura têm noção perfeitamente de qual deve ser o modo de atuação da religião, os seus objetivos e os seus limites. Esta religião (do espaço hospitalar) muito bem conectada com os objetivos científicos, de um lado, sabe, por exemplo, que não tem poder para eliminar a dor do paciente (pode sim, auxiliar o moribundo a suportá-la). De outro lado, autodestitui-se do papel de falar sobre "coisas transcendentais" naquele espaço, onde o foco de atenção deve estar voltado ao que o médico propõe. Ou seja, a proposta religiosa transcendental nunca deverá ofuscar a proposta médica/oficial. O paciente pode ter muita fé, "mas se realmente ele tem um problema delicadíssimo, não vai adiantar" (VR13). Então é necessário "separar uma coisa da outra" (VR13), pois "a gente nunca vai ter certeza se ele conseguiu pela fé ou o organismo que reagiu" (VR13). Nesse sentido, as atuações psiquiátrica e religiosa devem andar de mãos dadas para maximizar resultados: "É preciso que nós façamos um bom trabalho do nosso lado para eles terem força do lado/trabalho deles" (VR13). A ideia normalmente defendida é a de que não haja a substituição de uma pela outra pelos profissionais. Os pacientes, estes sim, até podem, mediante o seu poder de escolha, fazer opções nesse sentido.

[se acha que uma crença religiosa qualquer pode interferir no tratamento médico de alguma forma] Eu acho que pode, tanto para o bem como para o mal. A partir do momento que a pessoa coloca a religião acima da questão médica... porque uma coisa é certa, a fé não tira a dor, por exemplo. A fé pode ajudar você a suportar melhor a dor mais facilmente, mas não tira [...] No fundo, quando eu venho junto com a família e faço oração lá no quarto, no leito, não que o câncer vai desaparecer. Não acredito que o câncer vai desaparecer. Mas o fato de nós estarmos juntos, a pessoa vai ter força pra enfrentar o problema causado pelo câncer. (AR1).

[...] A gente precisa ter cuidado porque muitos pacientes acham que são espíritos, demônios. Não que eu desacredite. Eu, como ministro religioso, tenho obrigação de acreditar. A Bíblia diz isso de uma maneira muito clara. Eu acredito. Agora, confirmar isso, você faz um choque entre aquilo que o hospital está oferecendo e aquilo que você acredita. E esse diálogo conflituoso, essa convivência conflituosa não pode haver de maneira alguma. Então, você tem que ter muito tato/cuidado para que, na maioria das vezes, você drible aquilo. Você faça com que o doente se encaminhe ao foco de atenção ao que o 
médico está propondo. A atividade de assistência religiosa/espiritual não tem esse caráter específico de falar das coisas transcendentais $^{183}$. (AR3).

A religião racionalizada, na tentativa de abarcar todo o universo religioso, abre espaço para as diferentes maneiras de manifestação do conteúdo religioso. Por isso, a utilização de expressões como religiosidade, espiritualidade, pois estas estão bem disseminadas entre os diversos sujeitos. O religioso racionalizado está atento às novas tendências no campo religioso e, em vez de repudiá-las, faz com que sejam agregadas ao religioso instituído. Pode tratar-se de uma estratégia pura e simplesmente, mas pode significar também um novo modelo de religião institucionalizada que procura anexar esse religioso fluido (assim como a prática sacerdotal sempre procurou anexar a profecia, a magia). Esses sujeitos não se encerram às formas institucionalizadas de crer em algo; ao contrário, mostram-se com uma postura plástica, ainda que estritamente em vistas de uma posição centralizadora para manutenção do predomínio cristão. Semelhante plasticidade pode ser confirmada mediante expressões que remetem ao credo desinstitucionalizado, ou até mesmo ao ato de fé desvinculado da figura de um Deus qualquer que seja; no seu lugar aparecem outros referenciais como: força interior (VR6, AR3), energia (AR3), espiritualidade (AR1), pensamento positivo (AR1). No final das contas, tudo gira em torno de uma "questão de fé" (AR1) - "eu posso não acreditar e não acredito que uma figa vá trazer algum benefício pra mim, mas tem gente que acredita. O cara não acredita em Deus, mas acredita em duende. Eu acho que você tem que trabalhar com os elementos que a pessoa tem" (AR1).

A dinâmica do campo religioso, segundo Bourdieu, reside justamente nas relações conflitantes que opõem os diferentes interesses materiais e simbólicos de determinado grupo, por isso a mensagem religiosa mais eficaz é justamente aquela que dá respostas às necessidades de uma determinada posição social. Assim pode ocorrer, como se vê no caso do serviço religioso no IPQ, de os especialistas terem de reinterpretar uma mensagem para que esta possa responder à necessidade de determinados grupos. E essa reinterpretação será recorrente quanto mais houver uma distância econômica, social e cultural entre os produtores, os consumidores e os receptores. Por isso a mensagem pode ir mudando conforme as necessidades e

${ }^{183}$ A despeito disso, não é bem assim que a maior parte dos voluntários compreende a função da assistência religiosa. 
afastando-se assim do seu conteúdo original - ou do seu "núcleo duro" como afirma M27 -, tendo em vista as condições sociais dos diferentes grupos em determinada época ${ }^{184}$. A sobrevivência do cristianismo, por exemplo, estaria justamente no fato de ele ir adaptando-se em favor dos grupos que o adotam ao longo da história.

Assim, uma mesma visão de mundo, supostamente unitária, está impregnada de diferentes interpretações que existem justamente para responder às necessidades diversas que estão ocultas no interior do todo que é a mensagem religiosa. A mensagem é determinada por uma relação entre as forças materiais e as forças simbólicas; é que existe uma solidez na lógica do mercado de bens religiosos que faz com que o monopólio religioso esteja numa relação diretamente proporcional com a concessão às representações religiosas dos leigos. Ou seja, o que na aparência se mostra como uma unidade de visão de mundo monopolizadora, oculta no seu interior diversidades de interpretação religiosa que respondem às necessidades de diferentes camadas sociais. Isso é o que o Bourdieu (1999) denomina de efeito da compreensão dupla. Entretanto, apesar de a mensagem religiosa estar relacionada a interesses materiais e políticos, isso deve ser ocultado pelos especialistas tanto de si mesmos quanto aos outros num processo de conhecimento-desconhecimento.

\subsection{2 "Magicizado"}

A maior parte dos voluntários, apesar de serem constantemente orientados a adotar uma postura como a exposta anteriormente, acaba comportando-se de maneira diversa. A impressão que se tem é a de que eles tentam colocar em prática a atitude recomendada, mas não conseguem sustentá-la por muito tempo, o comportamento natural, o habitus preponderante que possuem é de outro tipo: é

\footnotetext{
184 Ocorre então uma relação entre o campo religioso e o campo do poder na medida em que a manutenção da ordem política deve-se à manutenção da ordem simbólica. Pois, é mediante essa última que se instaura "o consenso acerca da ordem do mundo mediante a imposição e a inculcação de esquemas de pensamentos comuns" (Bourdieu, 1999). Existe, portanto, uma relação de complementaridade entre o campo do poder e o campo religioso; são as relações entre eles que além de constituir o campo religioso, garantem a ordem social. A religião desempenha um importante papel enquanto mantenedora de uma ordem social, composta por classes (dominadas e dominantes) que buscam uma mensagem religiosa que responda aos seus interesses sociais e materiais.
} 
"magicizado". Eles sabem de todas as regras, conhecem a hierarquia hospitalar, estão cientes do lugar que ocupam e que, acima deles, tem os médicos e os enfermeiros. Tudo parece claro a eles, entretanto, não é suficiente para que abandonem um modo de pensar já muito arraigado na sua vida religiosa. $O$ monopólio religioso, segundo Bourdieu, pode ser colocado em xeque pelos leigos, e aqui se pode remontar àquela velha oposição entre sagrado e profano. Pois na medida em que ocorrem distinções no interior do campo religioso, a tendência é aqueles que ocupam uma posição inferior nesse campo professarem crenças que são tidas pela ideologia dominante como sendo magia, e vistas, portanto, como profanadoras da religião legítima. No entanto, essa oposição camufla na verdade, a oposição entre competências religiosas que estão relacionadas à distribuição desigual de um capital cultural, isso faz com que a magia esteja relacionada às classes desfavorecidas na medida em que ela tem como traço fundamental a resposta imediata a uma situação de carência. Todas as práticas religiosas dominadas estão fadadas a serem vistas como profanadoras, pois apenas o fato de elas existirem já é suficiente para contestar o monopólio.

Assim, é possível perceber que existe uma incerteza nos posicionamentos de alguns voluntários, os quais ora se posicionam de forma racionalizada, ora de forma "magicizada"; fato este que pode, às vezes, tornar difícil o seu enquadramento classificatório. Por exemplo, um mesmo voluntário a princípio considerado "magicizado" - por falar que "na oração, nós não falamos que tem que sarar, nós falamos que nós gostaríamos que sarasse, mas fica a critério de Deus. Deus no poder, não eu. Entrega o teu caminho ao Senhor. Confia Nele e tudo Ele fará. Não sou eu que vou fazer, é Deus" ${ }^{185}$ (VR3) - em outro momento apresenta características mais próximas do religioso racionalizado - "Eu sou evangélico, mas eu não entro em um quarto convidando para ir na [sic] igreja para se converter porque 'o pecado, porque pode ser que no dia de amanhã você morra em pecado'. Isso não se fala" (VR3). Vê-se nesse relato que as atitudes do entrevistado oscilam entre os dois extremos do posicionamento religioso.

Os posicionamentos "magicizados" são aqueles onde os agentes religiosos, ainda que orientados quanto à prioridade do comportamento racionalizado, colocam

${ }^{185}$ Esse tipo de atitude apesar de não ser mágica, pois não se trata de coerção, mas sim de súplica a um Deus não manipulável, atitude esta própria do homem religioso, se contrapõe à proposta religiosa racionalizada cabível na instituição hospitalar. 
em prática atitudes menos racionalizadas. Normalmente, os responsáveis por esse tipo de conduta são os voluntários religiosos que, apesar das formações a que são submetidos, parecem não assimilar realmente a conduta racionalizada, a qual foge do transcendentalismo - ainda que nele acredite - e possui uma plasticidade mediante os preceitos médico-científicos. Assim, veem-se depoimentos em que se faz referência a "episódios terríveis na própria psiquiatria", envolvendo a atuação distorcida de religiosos: "Uma vez um grupo evangélico ficou dois ou três anos sem poder participar porque começaram a falar que o que o doente tinha era demônio, e daí o professor lá proibiu" (AR3). A conduta "magicizada" vai de encontro à proposta psiquiátrica, ou seja, opõe-se ao tratamento médico-científico.

Os ensinamentos conferidos pelas autoridades religiosas não impedem que alguns voluntários enxerguem atuações sobrenaturais acontecendo ao lado de seu trabalho. Expressões como "milagre” (VR2, VR12), "plano de Deus” (VR2), "Deus vai operar na vida da pessoa" (VR2) dão o tom a esses discursos: "E quem somos nós para dar força para ele? A palavra tem poder, mas quem faz o milagre é Deus, é Jesus". (VR12). A própria atuação do médico pode ser vista também como algo da ordem do milagre e o hospital como uma casa de milagres (VR3) ${ }^{186}$.

Às vezes é como se a gente chegasse para eles e tivesse uma porta fechada e de repente começa a se abrir porque é tudo plano de Deus [...] A gente não pode fazer muita coisa, mas a gente leva a palavra de Deus porque Deus tudo pode. Quando Deus quer fazer na vida da pessoa, Deus trabalha o coração da pessoa. Basta que a pessoa aprenda a abrir seu coração, crer porque a palavra de Deus fala que a fé vem pelo ouvir falando de Deus. Ele dando ouvido no que a gente vai falar pra ele, ele pode obter muitas coisas, principalmente a cura interior. A cura da sua alma, do seu espírito e a física também porque Jesus quando andou na Terra fazia milagres. (VR2).

Há os que associam o milagre à força da mente e não a uma força sobrenatural. O milagre pode ser concedido por Deus, mas, por outro lado, pode ser proporcionado pela força da mente associada ao desejo. A depoente procura colocar-se num posicionamento racionalizado, mas acaba por assemelhar-se ao

\footnotetext{
${ }^{186}$ VR3 faz paralelo entre ciência e religião no sentido de que ambas têm o poder de conceder milagres. De um lado, o milagre2 transcendente relacionado à religião e, de outro lado, o milagre real obtido graças à competência do médico: "Jesus Cristo, quando andou pela face da Terra, disse que ele iria curar e que nós íamos curar muito mais. Estamos curando muito mais, é que nós não estamos percebendo. Me diga uma coisa: a senhora acredita em milagres? Aqui [Hospital das Clínicas] não é uma casa de milagres?" (VR3).
} 
outro caso apresentado aqui de oscilação entre o posicionamento "magicizado" e o racionalizado. Seu comportamento é hesitante, transformando o milagre que é algo da ordem do sobrenatural em algo do âmbito da força e reação da mente. O milagre ocupa seu lugar no discurso elaborado pela entrevistada, ele faz parte do simbolismo religioso do qual ela compartilha, assim precisa ser encaixado ou adaptado de alguma forma. A adaptação acontecerá mediante a substituição do transcendente pelo imanente, este representado pela força da mente, o pensamento positivo que faz "os anticorpos reagirem", evidenciando um mecanismo real onde o "eu psíquico comanda o corpo", culminando na melhora da pessoa. Ou seja, nas palavras de VR10, "quando a pessoa faz a promessa ela acaba exigindo tanto que é ela que realiza o milagre. Às vezes o santo nem interveio em nada, mas ela deseja tanto que ela própria realiza o milagre. Então, ela fazendo a promessa, é aquele pensamento positivo pra ela realizar o milagre. A mente é muito importante" $(\text { VR10) })^{187}$.

Entretanto, existe a divisão de competências que qualificará o que cabe a cada um. Uma coisa é o milagre da alma (realizado pelos religiosos), a outra é o milagre do corpo e da mente (realizado pelo médico quando cura o paciente através da sua competência): "A gente é médico da alma. Não do corpo" (VR10)/ "O médico é o que cuida do corpo. E nós cuidamos da alma, da parte espiritual" (VR3). Assim percebe-se que, a despeito do que se prega no hospital ${ }^{188}$ quanto ao fato de que corpo e alma não devem ser vistos separadamente, "o cristianismo moderno, confirma uma separação inequívoca entre a saúde e a salvação em benefício dessa última, abandonando, por assim dizer, os corpos à medicina para apenas se ocupar das almas" (LAPLANTINE, 2004, p. 224).

Segundo Concone (2003, p. 48), alguns argumentos a respeito da divisão cartesiana corpo/alma (que a autora percebe como enganosa) devem ser considerados. Um argumento comumente utilizado é o que trata essa cisão - no âmbito das terapias populares e religiosas - como sendo consequência do processo

\footnotetext{
${ }^{187}$ VR10, inicialmente, ameaça dar crédito à atitude racionalizada, colocando o sujeito como o único responsável pela sua melhora; entretanto, não conseguindo se desvencilhar totalmente do transcendentalismo, acaba por nomear de "milagre" os resultados obtidos com a força da mente. Essa entrevistada é um exemplo claro de voluntário que tenta levar em consideração a mentalidade racionalizada pregada pelos líderes, mas que não consegue sustentá-la até o fim.

188 Vide texto (já apresentado neste trabalho no tópico Capelania e assistência religiosa no HCFMUSP) confeccionado pelo CARE, diponível em: < http://www.hcnet.usp.br/adm/care> Acesso em: 12/03/08, onde fala-se da proposta de não desmembramento corpo/alma.
} 
de constituição do campo biomédico. Nessa perspectiva, a formação do referido campo haveria conduzido ao "encolhimento progressivo e inexorável das medicinas populares e religiosas", que no final das contas foram limitadas "ao nicho das "coisas do espírito' e às explicações relacionais" (aspas da autora). A despeito disso, Concone - ao estudar a Umbanda como espaço de cura e de resposta para a aflição - afirma que a visão unitária de corpo é recorrente na sociedade brasileira. Segundo a autora, em oposição à cultura erudita, a cultura popular não nutre uma visão dicotomizada de corpo e alma. Contrariamente o que ela faz é integrá-los. E é justamente essa integração levada a cabo pela cultura popular que propicia a passagem de uma medicina à outra, pois "em virtude do 'cartesianismo' científico, a atuação religiosa cuida de repor a totalidade" (CONCONE, 2003, p. 51, aspas da autora).

\subsubsection{1 "Segunda lança" e segurança adicional}

Os religiosos classificados como "magicizados" interpretam a cura do paciente, realizada através de métodos científicos, como sendo uma "atuação" de Deus na mão do médico. Deus passa a ser visto como desempenhando o papel tanto da "segunda lança"189 (tal como a bruxaria) - no caso da doença como um

\footnotetext{
${ }^{189}$ Evans-Pritchard (1978), nos seus estudos antropológicos sobre os Azande, fala da metáfora da "segunda lança" ou umbaga utilizada para "exprimir com muita clareza as relações entre as noções de causalidade mística e causalidade natural". Segundo o autor, para os Azande "os fatos não se explicam a si mesmos, ou fazem apenas parcialmente. Eles só podem ser integralmente explicados levando-se em consideração a bruxaria" (IBIDEM, p. 62). A bruxaria normalmente é a causa última do mal que acometeu um sujeito, mas existem as causas secundárias. Ela é a "segunda lança", explica "por que os acontecimentos são nocivos, e não como eles acontecem" (IBIDEM, p. 63). A doença não mata tout court, é preciso que associado a ela esteja a bruxaria como "segunda lança". O infortúnio é atribuído à bruxaria e não ao que visivelmente seriam as causas reais. Isso não quer dizer que estas últimas estejam excluídas de toda a compreensão, mas significa que são superpostas por um evento que possui valor moral; a bruxaria. É uma forma de explicação mística para infortúnios, como a doença, a morte. Existem as causas das doenças, mas não são elas que levam à morte, e sim, a bruxaria. Os Azande exprimem a causalidade de um modo diverso da cultura ocidental. Ao darem maior ênfase à bruxaria, não querem com isso menosprezar as causas secundárias presentes em todo o processo. O que fazem, na realidade, é condensar a cadeia de eventos e selecionar "a causa que é socialmente relevante e deixam o restante de lado" (EVANS-PRITCHARD, 1978, p. 63). Ou seja, está presente na sua crença de bruxaria "o conhecimento empírico da causa e efeito" (IBIDEM). $\mathrm{Na}$ verdade, a lógica da bruxaria não exclui a causalidade natural, ao contrário ela é muito consistente com [...] uma apreciação racional da natureza" (IBIDEM, p. 69).
} 
castigo de Deus - quanto da "segurança adicional"190 (tal qual a magia) - no sentido de que sem Deus seria impossível a efetuação do procedimento de cura, Ele é a garantia decisiva além do empírico; ou seja, apenas aparentemente a cura dá-se pela mão do médico. Não é que não se apele para os meios empíricos disponíveis no caso aqui, científicos -, mas ainda assim existe a ideia da recorrência a uma força exterior que irá "guiar a mão do médico". Entretanto, diversamente de um caráter mágico tal qual a bruxaria ou a magia, a atuação divina aqui explicitada aparece com um caráter de súplica, de pedido, e não de coação ao ser supremo.

O que se vê são dois universos nos quais, para além do conhecimento empírico racional, faz-se o uso de "uma dose adicional de sucesso"191 a uma empresa realizável" apesar da magia, apesar da religião. Ou seja, "[...] o uso de um procedimento mágico é secundário em relação à técnica empírica: não pode substituí-la, apenas auxiliá-la" (EVANS-PRITCHARD, 1978, p. 253). No caso em tela, a fé e os recursos proporcionados pela ciência são vistos como complementares. Além de complementares, eles podem ser mobilizados concomitantemente, de modo que um reforce o outro: "Se ele tem fé o tratamento vai ser melhor, ele vai sarar mais depressa" (VR1); "se o paciente tem mais uma integração com Deus, uma proximidade de Deus, ele vai se recuperar muito mais rápido" (VR12).

A associação positiva de ambos os recursos (científicos e religiosos) pode ser visualizada também mediante a ideia de que uma força superior pode "guiar a mão do médico" no sentido de interceder por esse profissional para que ele tenha "aquela mão boazinha" (VR11) para atender o paciente. O religioso dizer que "Deus vai atuar na mão do médico" é, de um lado, um eufemismo para conotar algo que

\footnotetext{
${ }^{190}$ Há, por sua vez, a utilização entre os Azande de elementos mágicos tanto para neutralizar a bruxaria quanto para fornecer segurança adicional além do empírico, do racional. O ritual mágico de uma maneira genérica é aquilo que não se pode deixar de fazer quando se vai realizar qualquer atividade que tem uma parte empírica, racional. Utilizam-se os conhecimentos técnicos que se tem, mas será o ato mágico que irá proteger contra os imponderáveis. Os rituais mágicos dão uma garantia além daquilo que se tem um controle racional. Enquanto a "segunda lança" ou bruxaria é uma explicação para os infortúnios, para o mal, a magia, os rituais mágicos, além de poderem ser utilizados para neutralizar a própria bruxaria (podem ser vistos como uma contrabruxaria), são responsáveis pelo sucesso. Ao passo que a bruxaria mata, a magia cura. As noções místicas não contradizem a experiência racional, empírica, apenas a justificam: "Raramente se exige que a magia produza os resultados sozinha; ela sempre está associada à ação empírica que realmente os produz" (p. 255). No caso das doenças, os Azande mesclam elementos empíricos e elementos mágicos no tratamento, isso quer dizer que "a referência da enfermidade ao sobrenatural" (p. 247) não faz com que eles negligenciem o tratamento dos sintomas.

191 Sucesso no que diz respeito à magia, porém, infortúnios e doenças no que diz respeito à bruxaria.
} 
não pode ser dito diretamente como, por exemplo, "Deus vai curar". De outro lado, é uma estratégia para deixar Deus bem vigente. Assim, no modelo de religião não racionalizada, Deus seria responsável por tudo - "a gente fala para essas pessoas do poder de Deus, que para Deus nada é impossível, que Deus está no controle de tudo" (VR12); afinal de contas, segundo essa concepção religiosa, "só Deus pode dar e só Deus pode tirar" (VR12). Esse Deus que tudo concede por vontade própria deu ao homem sabedoria, desse modo é graças a Ele que o cientista/médico existe - "o conhecimento do homem vem da inteligência que Deus dá. A Bíblia mesmo fala: 'O que seria do homem se não fosse Deus'? Se os médicos estudaram é porque Deus deu uma inteligência para eles" (VR2). Em resumo, "a medicina não existe sem Deus" (VR3). A prática médica é, nessa perspectiva, refém de um poder transcendente, ela não se sustenta por si só.

Eu tenho que orar para que Deus segure a mão dele e que ele faça a incisão no lugar certo. Ele pode até não ser crente, pode ser até que não acredite em Deus. Não importa. Ele está fazendo o que eu quero porque Deus está do meu lado. (VR3).

Os relatos mostram não se tratar exatamente de práticas mágicas de coerção do sagrado. O que parece acontecer não é a tentativa de manipulação de Deus, mas o esforço de manipular o médico. Ou seja, não parece ser o caso de uma manipulação no sentido mágico stricto sensu, mas uma súplica a Deus, mediante a qual ocorrerá uma "orientação" divina sobre a mão do médico. De toda forma, é colocado em prática um modelo interpretativo - no qual vigora um Deus onipotente que envia as doenças (procedendo mediante suas razões e desígnios, incompreensíveis ao homem), as quais "só Ele, se o desejar, poderá dar fim" (LAPLANTINE, 2004, p. 230) - não muito intelectualizado ou racionalizado nos moldes científicos (não no sentido da intelectualização religiosa).

No modelo racionalizado, no qual vigora uma distinção com lugares específicos de atuação de Deus e do médico, religião e ciência tendem a aparecer de forma conjunta, sem investidas de substituição de uma pela outra; aí talvez resida o meio-termo encontrado para evitar o choque, o confrontamento entre o mundo científico e o mundo religioso. De certo modo, uma retradução, como pensa 
Bourdieu $^{192}$, só que desta vez por parte dos religiosos (que se empenham em falar a linguagem do mundo científico), ou seja, mediante a retradução tradicionalmente realizada: do campo dominado em relação ao dominante.

\subsubsection{Capital religioso}

É importante que se procure correlacionar todas essas práticas ao tipo de capital religioso que se apresenta do lado dos dois serviços (o católico e o evangélico): quem tem mais e quem tem menos capital religioso e como isso se relaciona ao tipo de prática de atendimento. Ou seja, dentro do campo religioso, não se pode esquecer a distinção essencial entre os especialistas (entre os quais se faz a concorrência) e entre eles e os leigos.

Acredita-se que para além de conhecimento adquirido por intermédio de cursos, formações, diplomas, o que vale mais é a capacidade de discernimento e a boa vontade (VR4): "Não precisa ser letrado, humanamente [a pessoa] acha a sua medida" (VR4) ${ }^{193}$. Entretanto, essa postura pode ser perigosa, já que o bom senso é algo que não é inato ao indivíduo, depender apenas dele é arriscado em se tratando de um ambiente hospitalar. $E$ aí faz todo sentido o relato de AR1 ao afirmar: "Eu acho que é importante separar o religioso, eu religioso e os religiosos leigos" (AR1). Os frutos de uma defasagem em capital religioso - este substituído pela propalada "boa vontade" - escandalizam os especialistas religiosos (não somente estes, mas os psiquiatras referem-se a isso) que vez ou outra testemunham posturas ${ }^{194}$

\footnotetext{
${ }^{192}$ A questão da retradução (sobre a qual foi feita referência no Capítulo 1 da Parte I e que se aprofundará no Capítulo 7 da parte IV) elaborada por Bourdieu é no sentido de retraduzir o capital econômico em capital próprio a determinado campo, no caso capital simbólico. Aqui se trata da mesma ideia, entretanto ela é concretizada pelo campo científico em relação ao religioso e vice-versa, sendo que o primeiro caso chama mais atenção por se tratar de uma retradução às avessas: uma retradução do campo dominante em relação ao dominado.

${ }^{193}$ Alguns entrevistados afirmam que não tiveram que fazer curso para começar o trabalho na assistência religiosa do hospital. É o caso, por exemplo, de VR1. Mesmo porque, como afirma VR4, "não se exige nada de cursos aqui, tinha gente que mal sabia escrever, mas a boa vontade era maravilhosa. Tem pessoas que são humildes e legais por causa disso. Não têm ostentação. E não é o estudo que faz a ostentação, mas é o próprio modo de vida de cada um. Esses são os mais indicados para ter esse contato com os doentes. Porque ele vai encontrar doente de tudo quanto é cultura" (VR4).

${ }^{194}$ Como no caso de um grupo (proibido de entrar no IPQ por mais de dois anos), não identificado pelo depoente, que acreditava em possessão demoníaca no paciente e utilizava isso como meio de
} 
extremamente inadequadas, levadas a cabo por religiosos ${ }^{195}$ que "não têm uma capacidade intelectual, uma capacidade cultural para tratar a questão" (AR3), atribuindo todos os acontecimentos à intervenção de forças demoníacas (AR3). Apesar de semelhantes acontecimentos, os especialistas religiosos são os responsáveis pela qualidade do serviço religioso, eles selecionam o corpo de voluntários e, portanto, devem responder por isso. Ou seja, a responsabilidade em relação à defasagem, talvez estratégica para a não divisão do poder, recai estritamente sobre o corpo de especialistas.

\subsection{ASSISTÊNCIA RELIGIOSA: A CONSTITUIÇÃO ATUAL}

\subsubsection{Monopólio e diversidade religiosa ${ }^{196}$}

As autoridades religiosas - apoiadas pela administração do hospital e baseando-se no discurso de que o protestantismo e o catolicismo são as religiões com maior número de adeptos no Brasil - tentam de forma "pacífica" afastar as outras denominações religiosas, utilizando até mesmo o argumento de que "o direito do paciente fica desrespeitado" (AR3). As autoridades religiosas do hospital afirmam que o direito do paciente passa pela vontade de querer (ou não) ser assistido religiosamente; entretanto, como será visto mais adiante, alguns pacientes reclamam da falta de opções religiosas. Assim, o discurso de tolerância (comumente alardeado) que "jura de pés juntos" que há espaço para todos - composto por afirmações como: "[...] A convivência é boa porque tem que ser boa. [...] E na própria ordem de serviço, nos próprios escritos e documentos se faz constar que tem que

cura. Interessante, entretanto, que esse mesmo entrevistado afirma: "Eu não nego que haja teologicamente de modo algum, e também pela minha fé, eu não nego que haja essa presença maligna agindo no indivíduo eventualmente, ocasionalmente. Mas espera lá! Dentro de um ambiente hospitalar se promover isso!" (AR3). Ou seja, ainda que acredite na possibilidade de presença maligna, AR3 descarta esse ponto de vista no que concerne à sua atuação no serviço religioso hospitalar, adequando-se à postura religiosa exigida.

${ }^{195}$ Refere-se a determinado grupo de agentes religiosos que criou um conflito no interior do serviço evangélico.

${ }^{196}$ A noção de diversidade religiosa está relacionada à noção de pluralismo religioso, sistematizada por Peter Berger (1985). Essa noção é oposta à de monopólio religioso trabalhada por Bourdieu (1999). 
haver essa convivência. (AR3)" - soa um tanto quanto deslocado da realidade desse contexto.

É constitucional. O Brasil é um país laico. A admissão, aqui, se dá de qualquer religião. [...] Passa por nós [a entrada de religiosos], mas não sob o critério de autorizar ou não. Mas de contatá-lo/convidá-lo, de dizer que ele está sendo solicitado [...] Qualquer assistência espiritual que se dê aqui nós somos obrigados a facilitar a entrada [...] Se quer um chefe do candomblé, ele é chamado. Isso o hospital tem obrigação constitucional, dever constitucional de fazer. Não é obrigado a manter/ter aqui dentro. É como eu disse para você: "Mas por que católico e protestante?" Porque são as duas maiores. Então, a gente tem uma fonte de entendimento de que, como são as duas maiores, a demanda é maior, cabe ter aquelas duas porque há uma questão, inclusive, que interfere na dinâmica do próprio hospital. Se nós formos ter aqui todas as religiões ou dentro do protestantismo, todas as vertentes: neopentecostais, pentecostais de uma maneira que faça parte fica difícil de trabalhar. Ainda mais aqui no Hospital das Clínicas. O Hospital das Clínicas não é um hospital confessional. É um hospital público. Admite todos, realmente. Agora, aqui no hospital, se for ter todo mundo, não fica um negócio bom. O direito do paciente fica desrespeitado. Porque o direito não é o de nós prestarmos assistência ao paciente. Não é esse o direito fundamental. O direito fundamental é o paciente querer ou não ser assistido religiosamente. $\mathrm{E}$ a gente tem que ter muito cuidado ${ }^{197} . E$ pondo pessoas aqui dentro porque nós deliberamos que precisa fica uma situação difícil. Fica uma torre de Babel aqui dentro. O que a gente não pode deixar de lado é a grande e real possibilidade do proselitismo. De um querer que aquele paciente se torne adepto de sua religião. Isso é terrível! Isso não se faz! Mas corremos o risco disso: de termos um grupo imenso aqui. A homogeneização fica muito difícil. (AR3).

A constituição da capelania é uma questão polêmica ${ }^{198}$ e que suscita debates $^{199}$ e reflexões não somente entre os especialistas do campo religioso, mas também entre os especialistas do campo psiquiátrico, que por estarem de fora da questão conseguem perceber com mais lucidez as reais necessidades. Assim, eles alertam ser preciso proporcionar aos pacientes um atendimento religioso diversificado, já que no contexto brasileiro a questão da religião está bastante voltada para uma diversidade de opções. É necessário, pois, não fazer tábula rasa

\footnotetext{
197 Entretanto, alguns pacientes, por vezes, sentem-se incomodados com a presença religiosa dos próprios católicos e evangélicos. Sobre essa questão, ver Capítulo 8 (parte IV).

${ }_{198}$ A inserção de um membro espírita no CARE não aconteceu sem que se interpusessem obstáculos.

199 Aqui falam sobre a questão psiquiatras (1 mono-posicionado, 2 bi-posicionados, 4 neutros), enfermeiros (1 neutro e 1 bi-posicionado) e religiosos (2 racionalizados). Os psiquiatras e enfermeiros contestam o monopólio.
} 
de uma realidade como esta. No próprio IPQ - onde "tem pacientes de várias religiões, tem até muçulmanos, se você procurar nesse hospital inteiro você vai encontrar até muçulmanos" (E11) - há uma variação de opções religiosas, que, se desprezada, pode não atingir ao público como esperado. Assim ilustra o caso apontado por M10 em que o chefe da enfermaria, por acreditar que uma assistência religiosa iria auxiliar, requereu o serviço, entretanto este não teve repercussão - com exceção entre os católicos - pois havia "muita variação na crença dos pacientes" (M10).

Por esse motivo, alguns psiquiatras acreditam que: por ser a religiosidade algo tão diversificado se for haver um atendimento, este deve, por sua vez, ser diversificado (M3); ou seja, conciliar as necessidades plurais dos pacientes que estão internados (M18). Por isso mesmo questiona-se a medida invasiva de se colocar à disposição dos pacientes um rol tão restrito de opções religosas - "sempre vem só um: por que só católico? Por que não um pastor, um espírita? Todo mundo aqui acredita em tudo, a gente não pode forçar o evangélico a ouvir o católico ou o espírita" (E7). Ao agir desse modo, os religiosos não estão assumindo - e o hospital assinando embaixo, dando seu aval - que a questão espiritual "está ligada à cultura" (M23): "Se eu sou um budista, de repente chega um cara falando pra mim de santos católicos, de frei Inácio de Loyola, quem é esse cara?" (M23).

[O CARE] é um comitê que eu acho que tem o seu valor de estar prestando um serviço, mas que tem esse viés de não ser, por exemplo, representativo. Eu acho que o comitê, na minha opinião, deveria ser representativo de todas as religiões que aqui quisessem trabalhar e obviamente que ninguém aqui, vai vir fazer o proselitismo da sua religião porque vai ter regras a serem seguidas [...] Só que, ao criar esse comitê, não se pensou na questão na pluralidade das religiões e no respeito de igualdade que cada religião tem dentro do País. Se há interesse de determinadas religiões em participar do comitê, eu acho que esse comitê deveria estar aberto para essa opção. Mesmo que o comitê venha a ficar com dez, vinte ou até trinta itens, mas a questão da liberdade também e de igualdade porque todas as religiões perante o Estado são iguais. Não tem uma maior, melhor. Mesmo que as pessoas possam, inicialmente, alegar a questão da representatividade na população. Com base nisso se constitui um comitê! Mas se fosse assim, também então não teríamos mais negros nem índios, porque eles são minorias. As minorias devem estar participando, terem opção e não é só a questão de estar, mas ter igualdade porque o diferente não quer dizer que ele seja menos valioso. (M13). 
Pode acontecer, por vezes, de esse esquema rígido de não tolerância religiosa dentro do hospital ser burlado, porquanto existe a possibilidade de que, com extrema ladinice, se consiga engrupir o esquema de monitoração de entrada e saída de religiosos: "O registro pode liberar isso. Se ele tiver a carteira de representante religioso, o registro pode fazer isso. Não precisa necessariamente passar por nós (AR1)". Não é possível afirmar com segurança que há "clandestinidade religiosa" no hospital, entretanto, pode-se aventar a real possibilidade de uma situação escapar do controle (M17). Por exemplo, como relata M14, um caso de uma visita religiosa que passou por visita informal: "Não sei se foi uma visita ou se foi uma coisa que foi clara com a instituição. Eu não sei como funcionou" (M14).

Há duas configurações distintas do universo religioso: o pluralismo religioso e o monopólio religioso. As duas foram aplicadas a contextos e momentos históricos diferentes, que são os Estados Unidos moderno e a Europa cristã tradicional sucessivamente. Essas duas conjunturas diferentes - investigadas por Peter Berger $(1985)^{200}$ e Pierre Bourdieu (1999) - permanecem atualizadas para refletir sobre a configuração religiosa contemporânea, podendo, portanto, serem resgatadas para entender o espaço ocupado pelos religiosos do HCFMUSP: de monopólio dentro de um contexto maior de diversidade e pluralismo religioso. Necessário apresentar, antes de qualquer coisa, os contrapontos que estão por trás dessas diferentes abordagens: Bourdieu contrapõe o monopólio sacerdotal ao autoconsumo religioso (quem produz também consome os bens religiosos) ${ }^{201}$, enquanto Berger o contrapõe ao pluralismo. Aparentemente poderá notar-se que os dois autores fazem uso de expressões idênticas para falar dessas duas situações diversas ${ }^{202}$, mas é necessário que fique claro que um fala de conflito numa situação de monopólio, onde as

\footnotetext{
${ }^{200}$ Peter Berger (1985) é considerado o autor que mais investigou a fundo a analogia entre economia e religião, ao fazer análise do "mercado religioso". Esse feito foi realizado na obra O Dossel sagrado. 201 Segundo Bourdieu (1999), o campo religioso foi precedido por uma situação de autoconsumo. Nesta, os produtores dos bens religiosos eram também os seus consumidores. A partir do momento que são expropriados pelos sacerdotes, os quais se tornam os detentores do monopólio legítimo da gestão desses bens, os antigos produtores são convertidos em leigos. Dessa feita, eles passam a ser estranhos ao sagrado, todavia são constituídos por um habitus religioso que os faz sentir a necessidade de consumi-los.

${ }^{202}$ Apesar de ter em mente que se trata de situações diferentes aplicadas a épocas distintas, pode-se ficar confuso com a leitura de Bourdieu quando este autor utiliza termos como: "capital religioso", "mercado de bens religiosos", "necessidades dos leigos", "produtores de bens de salvação", "serviços religiosos", "lógica do mercado de bens religiosos", "menor custo", "mínimo risco". São expressões muito próprias a uma situação de mercado e que se não vistas de forma cautelosa podem levar a crer que o autor fala de algo muito parecido com o que Berger procurou teorizar.
} 
instâncias religiosas estão hierarquizadas e o outro trata da existência de várias instâncias religiosas, as quais praticam uma concorrência racionalizada, onde há lugar para todos ${ }^{203}$. No pluralismo proposto por Berger, fala-se de uma hierarquia no interior das instâncias, mas é uma hierarquia que visa à funcionalidade, não à exclusão.

É possível perceber, na leitura dos referidos autores, dois aspectos diversos: enquanto Bourdieu fala de legitimações, distinções, inculcações na ordem social por intermédio da religião detentora do monopólio, Berger faz notar outro tipo de relação entre as instâncias religiosas e destas com o todo social que é de respostas efetivas a um mundo social, porém fragmentado, agora se fala de mundos parciais.

Na perspectiva de Berger, a imposição de uma religião dominante mediante coerção é um acontecimento que - com a secularização e a consequente separação entre Estado e religião - é tido por terminado. Agora, ao contrário, o Estado passa a desempenhar o papel de guardião imparcial da livre concorrência frente aos grupos religiosos. Mediante esse processo de livre concorrência, a religião passa a ser espontaneamente adotada; trata-se desse modo de uma religião individualizada com contornos diversos do tipo de religião definida por Durkheim, a qual teria como papel atribuir um significado único que abrigasse a todos. Esse novo formato de religiosidade deixa de construir um único mundo e, diversamente, empenha-se na construção de mundos parciais. Dessa feita, a religião passará a ter a intimidade como lugar de atuação e o pluralismo será o resultado de uma religião que se desfaz do seu caráter coletivo. Nessa nova conformação religiosa, diversos grupos adquirem status legal perante o Estado e mantêm competição uns com os outros. Ou seja, a derrocada do monopólio e a ascensão do pluralismo deveram-se, em grande medida, à secularização e ao fim da proteção fornecida pelo aparato estatal à religião dominante ${ }^{204}$.

Já a forma como Bourdieu (1999) apresenta o campo religioso é mais controversa. $\mathrm{O}$ autor pode levar frequentemente a crer que há uma sobreposição

\footnotetext{
${ }^{203} \mathrm{O}$ campo pluralista foi conflitivo em suas origens, mas sua racionalização viabilizou a concorrência entre adversários vistos como legítimos.

${ }^{204}$ Conforme Berger (1985), o primeiro deslocamento em direção ao pluralismo foi realizado pelas guerras de religiões e o rompimento da cristandade. Entretanto, o pluralismo, tal como se visualiza atualmente, aconteceu primeiramente nos Estados Unidos a partir do estabelecimento de um sistema de denominações concorrentes entre si, possuidoras de um mesmo status legal. Porém, a competição extrapola o nível das religiões entre si, ela é também extrarreligiosa, ou seja, outros grupos competem com a religião na definição do mundo.
} 
dos aspectos ideológicos aos aspectos simbólicos ${ }^{205}$, isso porque ele coloca em relevo a problemática da dominação ao refletir a respeito da questão religiosa, por exemplo. Bourdieu vê nos sistemas simbólicos princípios de estruturação do mundo, de transformação da prática social, pois existiria uma relação entre as estruturas sociais e as estruturas mentais que é intermediada pelos símbolos. É nesse sentido que ele afirma que enquanto sistema simbólico "a religião contribui para a imposição (dissimulada) dos princípios de estruturação da percepção e do pensamento do mundo e, em particular, do mundo social” (BOURDIEU, 1999). Isso acontece na medida em que ela "impõe um sistema de práticas e de representações cuja estrutura objetivamente fundada em um princípio de divisão política apresenta-se como a estrutura natural-sobrenatural do cosmos" (IBIDEM, destaque nosso).

Porém, há os que, embora atentos à importância da incorporação da dimensão política no estudo dos processos culturais, mostram-se preocupados com o perigo de alargar-se a tal ponto conceitos como dominação e ideologia, de forma que o cultural, o simbólico só faça sentido quando analisado tendo como pano de fundo o poder (DURHAM, 1984).

Apesar da perspectiva diferente abraçada pelo autor e todas as possíveis críticas a ela dirigidas, sua análise é pertinente para o que ocorre no interior do campo religioso. Neste ele vê, a priori, uma dinâmica que é constantemente movimentada por uma relação de poder, onde ocorre uma divisão de prestígio quanto ao simbólico e ao econômico. Existiria, por exemplo, na religião enquanto sistema simbólico, uma ideologia de "inculcação", "consagração", "naturalização" e "manutenção" de uma ordem social (expressões utilizadas por Bourdieu), e através dessa ideologia é que se delimitaria "o campo do que merece ser discutido em oposição ao que está fora de discussão"; a função ideológica da religião seria então uma "função prática e política de absolutização do relativo e de legitimação do arbitrário" (BOURDIEU, 1999, p. 46).

Como se sabe, Bourdieu baseia-se na epistemologia weberiana para elaborar vários dos seus conceitos, haja vista os escritos relativos à religião. Em

${ }^{205} \mathrm{O}$ autor, o qual trabalha com a ideia de que os sistemas simbólicos (no caso a religião) são veículos de poder e de política, afirma que "os etnólogos tendem hoje a descartar a questão das relações entre a estrutura social e a estrutura das representações míticas ou religiosas". Ele critica Lévi-Strauss por este "rejeitar o princípio mesmo da relação entre as estruturas dos sistemas simbólicos e as estruturas sociais" (BOURDIEU, 1999, p. 31), procurando apenas, com a sua ciência estruturalista, descobrir a lógica imanente do mito enquanto estrutura estruturada. 
seus estudos, Weber afirma contundentemente que ao se falar da religião está se falando do mundo. A linguagem religiosa tem como especialidade traduzir tudo numa língua celestial onde o mundo não é visto, onde a "alquimia religiosa faz 'da necessidade virtude"”206, é necessário por isso entender como esse discurso celestial fala do mundo. Bourdieu não é especialista da religião ${ }^{207}$, o que interessa a ele é a produção do mundo social, a reprodução, ao fazer uma leitura da religião é para mostrá-la como um elemento que intervém na produção e na reprodução do mundo social. Ou seja, a religião não é vista apenas de dentro, na sua autonomia, ela é também analisada dentro de uma construção maior que é o mundo social. Por isso, as análises do autor são tão profundas e bem realizadas.

Bourdieu preza por uma politização na abordagem sociológica dos diferentes espaços sociais de modo a investigar como os sistemas simbólicos legitimam uma situação de dominação existente, como um determinado referencial simbólico define interesses específicos. É verdade que a ação humana é construída e ordenada através de símbolos, os quais podem tomar a forma de discursos, de mitos, dogmas, e estão presentes em qualquer prática social, sendo eles que a exprimem e a justificam. Entretanto, Bourdieu não se satisfaz apenas com esse tipo de análise, ele vai além desse processo procurando buscar as relações de poder que advêm dele. Pode-se enxergar isso quando o autor afirma que "o princípio do efeito de consagração reside no fato de que a ideologia e a prática religiosa cumprem uma função de conhecimento-desconhecimento ${ }^{208}$, basta perceber que os especialistas religiosos devem forçosamente ocultar a si mesmos e aos outros que a razão de suas lutas são interesses políticos" (BOURDIEU, 1999, p. 54). Isso fica mais evidente ainda na seguinte afirmação:

A estrutura das relações objetivas entre as instâncias que ocupam posições diferentes nas relações de produção, reprodução e distribuição de bens religiosos tende a reproduzir a estrutura das relações de força entre os grupos ou classes, embora sob a forma transfigurada e disfarçada de um campo de relações de força entre

\footnotetext{
206 Inspirado na teoria de Weber, o qual "nos conduz ao núcleo do sistema de produção da ideologia religiosa" (BOURDIEU, 1999, p. 33), Bourdieu faz referência ao que ele chama "alquimia religiosa", mediante a qual é realizada a metamorfose das relações sociais em relações sobrenaturais, "inscritas na natureza das coisas e portanto justificadas" (IBIDEM).

207 Assim como faz uma leitura da escola e não é um especialista da educação, ele percebe a escola como elemento que intervém no sistema de classificação das sociedades.

${ }^{208}$ Questão sobre a qual já foi feita referência em outro momento do texto.
} 
instâncias em luta pela manutenção ou pela subversão da ordem simbólica. (BOURDIEU, 1999, p. 70, destaque do autor).

Ou seja, apesar de tomar como ponto de partida os sistemas simbólicos, Bourdieu os enxerga como meios de ação e expressão. Por isso, aqueles antropólogos que tratam a cultura como linguagem são criticados, pois eles veem a cultura como um texto a ser decifrado, e ademais, ao abandonar a perspectiva dos "homens atuantes", separam o significado da ação transformadora do homem. Entretanto, ao trabalhar de forma insistente uma relação entre o campo do poder e o campo religioso ${ }^{209}$, o autor não deixa de estar atento à autonomia. Como já comentado em outro momento, para Bourdieu, contrariamente à ideia de determinismo, há a autonomia dos diferentes campos. Com isso, quer evidenciar-se que a prática social não é determinada, ela admite improvisações e transformações.

\subsubsection{Dominação religiosa ${ }^{210}$}

O serviço religioso católico e o serviço religioso evangélico compõem a capelania hospitalar e oficialmente têm a autorização para enquadrar o que é permitido ("o que faz bem") e o que é proibido ("o que faz mal"). Afirma-se, normalmente, que qualquer grupo pode atender o seu paciente, o que se proíbe é "fazer trabalho direto dentro" (AR1) do HCFMUSP.

Qualquer grupo religioso tem a permissão de entrar porque todo paciente tem direito, se quiser, de receber o seu representante religioso. Porém, pra fazer trabalho aqui hoje só quem tem permissão... O trabalho que eu falo é você ter uma atividade aqui, você visitar todos os leitos porque quem vem atender o paciente vem atender só aquele paciente especificamente. Hoje, pela determinação da superintendência, é o serviço religioso católico e evangélico. Agora, se uma comunidade judaica ou islamita, aí teria que fazer um processo diferente porque o pessoal tem que se enquadrar dentro das normas que existem. Porém, se a pessoa é judeu, ele não vai querer seguir as mesmas normas de católicos ou evangélicos. [...] Nós temos dois serviços cristãos. Na época achou-

209 Segundo Bourdieu (1999, p. 73), "ao que tudo indica, a estrutura das relações entre o campo do poder e o campo religioso comanda a configuração da estrutura das relações constitutivas do campo religioso".

210 Aqui religiosos (3 "magicizados" e 3 racionalizados) abordam a questão. 
se por bem que se algum outro serviço de uma outra denominação não cristã quisesse poderia fazer parte, mas na época falou: "Bom, vamos deixar em aberto. Se alguém procurar, tudo bem. Se ninguém procurar, vamos deixar". (AR1).

E, assim, amparados no argumento de "não confundir a cabeça do paciente" e de que tudo passa "pela determinação da superintendência", os especialistas religiosos restringem a participação de outros grupos atrelando-a à questão da competência e da necessidade. Mesmo a participação residual de pentecostais e a predominância dos históricos no serviço de capelania são justificadas em função além do argumento de que o movimento neopentecostal não existia na época da criação do serviço religioso - da falta de formação desses grupos, os quais não possuem "qualquer estudo ou formação teológica e filosófica". (AR3). Dessa forma, eles cerram fileiras, ainda que não assumidamente, contra a ideia de uma igualdade de oportunidades para todos os grupos, defendida no contexto de diversidade religiosa. Ao contrário, acreditam que a oportunidade de participação deve ser muito bem avaliada em cada contexto e não necessariamente estar vinculada à máxima "Se fizer para um vai ter que fazer para todo mundo!" (AR1). "Se tiver um capelão padre então tem que contratar tudo porque todo mundo tem! Você contrata todo médico que vem aqui porque tem CRM ou você contrata porque o cara tem competência e o hospital tem necessidade?" [...] (AR1).

Segundo Bourdieu (1999), a estrutura social é vista como um sistema hierarquizado de poder e privilégio, tanto no que concerne às relações materiais como às relações simbólicas. Por isso, é necessário, para entender a dinâmica do campo religioso, levar-se em conta uma série de interesses que estão por trás da mensagem religiosa e dos seus portadores, os quais, no final das contas, cumprem o papel de defensores de determinados grupos.

Em vista do monopólio, a religião assume uma função ideológica, a qual determinará o que merece ou não ser discutido, colocando em prática "a absolutização do relativo e a legitimação do arbitrário" (BOURDIEU, 1999, p. 46), legitimando assim determinadas posições sociais existentes na sociedade $\mathrm{e}$ reproduzindo a estrutura das relações econômicas e sociais. É que a religião, ao cumprir funções sociais, não apenas dá respostas às aflições existenciais do indivíduo (teodiceia do sofrimento), mas, além disso, fornece a ele justificativas quanto à posição social que ele ocupa (sociodiceia). 
Tendo em vista uma distribuição desigual de capital religioso, os grupos que estão no topo dessa hierarquia encontram-se em condições de se impor, enquanto detentores de um maior capital, na concorrência pelo monopólio da gestão dos bens de salvação, é uma verdadeira competição pela legitimidade religiosa. Assim, a luta pelo monopólio inicialmente gira em torno da oposição entre Igreja e a seita, com a Igreja constantemente tentando barrar a entrada de novas empresas de salvação. A Igreja possui um capital de graça institucional, que faz com que os sacerdotes tenham a sua autoridade legitimada ${ }^{211}$ em contraposição ao profeta e ao feiticeiro.

A despeito disso, o profeta consegue realizar um acúmulo inicial de capital religioso, mediante a conquista de uma autoridade que é instável, e coloca em questão o monopólio dos instrumentos de salvação. E o feiticeiro, o qual é sustentado pelas classes inferiores, impõe à Igreja a ritualização das práticas religiosas. Essas contestações fazem com que a Igreja seja obrigada a fazer concessões (obviamente que com intuito de eliminar tanto o profeta quanto 0 feiticeiro) no sentido de acomodações que no final das contas tenderão a absorver essas formas de religiosidades de modo a não reconhecê-las. É que somente uma burocratização da religião pode manter o capital religioso de forma a dar-lhe um caráter contínuo e duradouro e reproduzi-lo, o que nem a profecia nem a feitiçaria conseguem fazer.

Outra oposição que se desenvolve paralelamente àquela entre Igreja e profeta é a oposição dentro da própria Igreja entre a ortodoxia e a heresia; é luta por poder que se dá não só externamente em relação aos leigos e ao profeta e feiticeiro, bem como dentro do próprio subcampo teológico entre os especialistas. Começam a se desenvolver conflitos pela conquista da autoridade espiritual ${ }^{212}$.

211 No campo religioso, Bourdieu (1999, p. 61) fala frequentemente de uma conservação do monopólio do poder simbólico que só pode ocorrer se a instituição que o detém tenha a seguinte aptidão: "Fazer reconhecer, por parte daqueles que dela estão excluídos, a legitimidade de sua exclusão (ou seja, fazendo com que desconheçam o arbitrário da monopolização de um poder e de uma competência acessíveis a qualquer arrivista)". Existem, consequentemente, nesse cenário de luta por monopólio e poder, as contraideologias, levadas a cabo pelo profeta e o feiticeiro, e até mesmo pelos sacerdotes heréticos, que visam contestar esse monopólio, mas que no final das contas, segundo o autor, quando se legitimam, assumem a mesma função de dominação e atraem, assim, novas contestações. E é segundo essa lógica que o campo religioso movimenta-se e mantémse vivo, é essa luta por poder que é o motor e as engrenagens responsáveis pela dinâmica desse campo.

212 Os cismas clericais se transformam em heresias ao defenderem a igualdade de qualificações religiosas. 
O discurso das autoridades religiosas no HCFMUSP, mormente, apresentase como favorável à presença de outros grupos, mas sem representação no CARE, o qual tem como proposta "servir de apoio ou de ponte para determinadas religiões que não estão presentes no comitê", mas que são referidas nas necessidades espirituais dos pacientes. A institucionalização conduziria a presença de uma miríade de religiões. Isso possivelmente colocaria em risco a autonomia e o monopólio dos cultos cristãos, já que nesse espaço - onde é proibida a disputa religiosa pelo paciente (como apregoado pelas autoridades religiosas aí presentes) haveria que se concorrer com outros tipos de propostas religiosas. Assim, outros grupos não têm livre acesso, a sua entrada é possível, mas "depende da liberação do CARE, que é o grupo de assistência religiosa do hospital” (AR3).

Eu acho normal, até porque eu vejo religião uma coisa cultural. Se eu tivesse nascido em Israel, eu seria judeu. Se tivesse nascido na China, provavelmente seria budista. Eu não vejo nenhum problema em ter outra conviç̧ão religiosa aqui dentro. Eu acho que não pode misturar coisas. Por exemplo, o espiritismo: "Nós somos religião" Não, não é religião, porque o evangelho é diferente, porque 0 evangelho é segundo Allan Kardec. "Mas é o mesmo de Jesus." "Se é o mesmo de Jesus, pra que fazer outro?" "Mas nós somos cristãos." "Se vocês são cristãos, não se enquadra [sic] no serviço... deve se enquadrar no serviço católico e evangélico, não num outro". Agora, eu não teria nenhum problema em ter outra religião aqui. (AR1).

O preconceito com relação à presença de outras religiões é real e, frequentemente, constatado nas falas dos voluntários. Chega-se mesmo a afirmar que realmente só deveriam ter representação na assistência religiosa os católicos e evangélicos, pois "o resto não é religião" (VR8); ou ainda, como VR1, ao dizer que "depende da religião, não dá pra ter certas religiões fanáticas [inclui a Igreja Universal do Reino de Deus (IURD) entre estas, que classifica como um comércio e não uma religião]" (VR1). Entretanto, é interessante a boa convivência (divulgada por alguns religiosos) entre católicos e evangélicos. Estes, até mesmo fazem uso do espaço católico para se reunirem: "Fazemos culto na capela cheia de santo [...] Agora tem gente que não entra por causa do santo" (VR3).

Os relatos anteriores apontam para dois aspectos (compartilhados tanto por voluntários quanto pelas autoridades religiosas), o conflito religioso e a exclusividade religiosa que, no final das contas, tem como expectativa uma coisa apenas: a 
detenção de uma "posição sacerdotal central". Assim, inevitavelmente, a centralização religiosa que coloca em parceria os católicos e evangélicos é levada a cabo na assistência religiosa hospitalar a despeito da diversidade de religião/religiosidade que possa ser demandada tanto pelos profissionais de saúde quanto pelos pacientes e seus familiares.

\subsubsection{Posição sacerdotal central: estratégia ${ }^{213}$}

Ainda que não seja oficializada, há certamente uma aliança entre autoridades religiosas católica e evangélica (pastor e padre), pois estas consideram que a abertura para a presença oficializada de outros grupos religiosos pode complexificar a ação religiosa dentro do espaço hospitalar. Dessa forma, fazem resistência para não deixar entrar. Isso exemplifica a asserção feita por Bourdieu (e anteriormente muito bem trabalhada por $W^{2} e^{214}$ ) de que as religiões não são apenas ideias, mas também interesses.

Não as idéias, mas os interesses material e ideal governam diretamente a coduta do homem. Muito frequentemente, as 'imagens mundiais' criadas pelas 'idéias' determinaram, qual manobreiros, os trilhos pelos quais a ação foi levada pela dinâmica do interesse. 'De que' e 'para que' o homem desejava ser redimido e, não nos esqueçamos, 'podia' ser redimido, dependia da imagem que ele tinha do mundo. (WEBER, 1963, p. 323, aspas do autor).

Pode haver riscos de uma contaminação de elementos considerados "mágicos" na prática religiosa intelectualizada. Talvez seja por essa razão que as duas autoridades religiosas (padre e pastor) são aliadas numa posição sacerdotal central, e sintam os outros grupos ${ }^{215}$ como feiticeiros, isto é, como fazendo parte de uma religião mágica, já que eles vêm fazendo concorrência mediante promessas como "Deus pode curar, vai ter milagre" (que é o lado feiticeiro da religião). Entretanto, a religião nos moldes éticos, ainda que esteja voltada para este mundo,

\footnotetext{
${ }^{213}$ Cinco religiosos "magicizados" e três racionalizados abordam a questão.

${ }^{214}$ Segundo Ortiz (1983, p. 22), a análise feita por Bourdieu da ação enquanto maximização dos lucros ou investimento é, na verdade, uma retomada da sociologia dos interesses de Max Weber.

${ }^{215}$ Entretanto, como é possível notar, os próprios voluntários ligados aos dois serviços religiosos possuem esse tipo de comportamento rechaçado pelas autoridades religiosas.
} 
fazendo com que o homem atue nele de acordo com os mandatos divinos ${ }^{216}$, dá ênfase mais à ética do que propriamente à súplica ao Deus no sentido de obter a salvação, a cura milagrosa.

Os especialistas precisam dos leigos, por intermédio dos quais procuram alargar sua participação para ocupar o espaço. Ou seja, preencher o espaço é uma estratégia religiosa - se a autoridade religiosa não pode ir, envia no seu lugar um voluntário, assim o doente se sente ligado e não vai receber, por exemplo, outro grupo religioso. Para isso, as autoridades religiosas precisam ter à sua disposição um grupo de pessoas, que na sua maior parte não é composto por especialistas, há pessoas de todos os níveis de capital religioso, o que faz com que elas façam "nas costas" dos especialistas um trabalho antinômico ao esperado, o qual propala curas, milagres.

A posição centralizadora ${ }^{217}$ colocada em prática facilita a homogeneização da assistência religiosa, visto que possibilita o entrosamento entre os religiosos. Obviamente, o relacionamento entre religiosos de uma mesma linhagem tem probabilidades maiores de acontecer de forma tranquila, sem grandes tumultos (ainda que possa haver alguns atritos). Por exemplo, é possível notar uma postura de tolerância dos evangélicos em relação aos católicos, pois estes se aproximam da perspectiva evangélica, já que são cristãos. Eles podem ser encarados como diferentes no sentido de terem um modo distinto de enxergar o cristianismo, mas isso não os torna totalmente contrários. Além do mais, a ideia de que "Deus é um só" ajuda a amenizar as discrepâncias (entre cristãos, naturalmente), ela é o lugarcomum dos religiosos, especialmente dos protestantes/pentecostais. Para estes não importa (VR12) o fato de existirem várias denominações dentro do protestantismo, pois "ultimamente têm surgido muitas placas de igreja, mas Deus é um só". (VR2). Os católicos também acreditam que "a palavra de Deus é uma só (VR13) e que por isso não se deve "desfazer de uma para a outra" (VR13), entretanto, é conhecimento

\footnotetext{
${ }^{216}$ Sendo que a cura da alma para que se atinja o outro mundo na condição de salvo tem que se dar (ou ao menos se evidenciar) no mundo temporal. Segundo Weber (2004), a ação do protestante dáse nesse mundo, especialmente no econômico e profissional. Ele retira-se do mundo, não usufruindo dos seus prazeres, numa recusa seletiva. Porém, não se trata de uma atitude religiosa extramundana; ao contrário diz respeito ao ascetismo intramundano. Ou seja, a salvação é uma finalidade, mas em função dela dá-se a atuação no mundo conforme requerida por Deus.

${ }^{217}$ A ideia de ampliar a representação do CARE, por intermédio da participação de outros grupos posta em prática pela recente inserção dos espíritas no referido comitê - ainda não é forte o suficiente. Tal iniciativa tem sido, ainda que disfarçadamente, embargada.
} 
de todos que sempre "tem uns mais radicais" (VR4). Os voluntários católicos são mais tolerantes em relação aos espíritas, pois acreditam que estes "dão muito valor à pessoa doente" (VR1) e "aceitam a Igreja Católica, rezam juntos, vêm à missa, faz [sic] uma fusão" (VR10).

Deus pode aparecer como um só também na perspectiva de alguns pacientes que, de seu lado, não fazem distinção, às vezes, entre as denominações confundindo a missa católica com o culto evangélico, o que se pode explicar pelo fato de que, para além da indistinção, "a pessoa que está doente aceita tudo que vem" (VR13). Além disso, acontece, por exemplo, de o evangélico convertido sentir falta do passado católico e querer um contato ainda que provisório: "Geralmente são os evangélicos, os que já foram católicos, toda hora que a gente vai fazer as orações, vai receber a comunhão que é muito sagrada, tem aquela saudade" (VR7).

O ecumenismo é a quinta-essência do discurso dos religiosos ${ }^{218}$, seja no sentido de querer expressar a importância do trabalho em conjunto - "a gente trabalha em uma linha ecumênica; ninguém está escrito aqui católico, evangélico" (VR4) - seja para demarcar uma característica do serviço religioso, que é o seu traço cristão: "Ecumênico são todas as religiões porque o papa, quando esteve no Brasil, falou que a gente tem que ser ecumênico, respeitar todas as religiões que tenham batismo e tenham tido Pai, Filho e Espírito Santo. Cristãs" (VR10).

A situação pluralista, descrita por Berger (1985), é análoga à situação e à lógica de mercado. Desse modo, as instituições religiosas assemelham-se a agências de mercado $e$ as tradições religiosas tornam-se muito parecidas a mercadorias de consumo. A partir do momento em que a religião adquire esse caráter mercadológico, ela será obrigada, assim como o mercado econômico, a produzir resultados e a reduzir os riscos nas suas empreitadas. Na busca por resultados, ela será forçada a se burocratizar para que se torne mais eficiente. Tais características mercantis farão com que todas as religiões dessa configuração venham a ser muito semelhantes umas em relação às outras, a ponto de haver o nivelamento de tipos distintos, como o sacerdote e o profeta, visto que agora não

\footnotetext{
${ }^{218} \mathrm{O}$ discurso do ecumenismo parece funcionar no que concerne ao protestantismo de um modo geral, o que não acontece em relação ao espiritismo kardecista com o qual se choca em muitos aspectos, já que este último não é considerado como fazendo parte do cristianismo pelos religiosos. Como já foi notado em outro momento, o ecumenismo é em relação aos cultos cristãos; ou seja, é tomado de um ponto de vista teológico.
} 
importa o perfil, mas sim a adaptação às exigências do papel burocrático. estabelecimento de vários pontos em comum em decorrência da burocratização faz com que se abra caminho para o ecumenismo, para uma colaboração amigável entre os vários grupos, a qual é exigida pelo processo de pluralização ${ }^{219}$. O relato de AR1 ilustra muito bem essa questão: "Acho que isso é uma tendência que vai caminhar porque hoje tudo é a questão do cliente: isso satisfaz a pessoa, traz o bem-estar da pessoa? Isso é coisa que, na minha maneira de ver, vai caminhar". O depoente curva-se, pois, ao que parece ser a realidade e um caminho sem volta para o campo religioso: a criação de um mercado religioso onde todas as religiões competem formalmente ${ }^{220}$ em igualdade de condições.

A definição do produto religioso pela clientela ${ }^{221}$ será um dos resultados da situação pluralista. Assim, o conteúdo religioso é alterado de acordo com suas necessidades, pois, o que conta agora, em última instância, é a preferência do consumidor, tal qual numa economia de mercado. Sendo que a secularização e o tipo de camada social também influenciam na direção da mudança do produto. $O$ lugar institucional da religião é outro fator responsável por essa mudança, ou seja, produtos que correspondam às necessidades da esfera privada são preferidos pelo consumidor.

\footnotetext{
${ }^{219}$ Segundo Berger (1985), a cooperação é necessária para que haja a racionalização da própria competição, de forma que esta seja viabilizada e venha a funcionar realmente. Ou seja, a livre concorrência impõe restrições para impedir possíveis deslealdades nas disputas. Com isso, a competição é racionalizada por meio da cartelização, o que possibilita um acordo entre os diversos concorrentes e auxilia na redução dos possíveis riscos de uma empreitada. Em outras palavras, a cartelização reduz o número de concorrentes mediante incorporações, e faz com que os restantes estruturem o mercado por intermédio de acordos mútuos. Não obstante, contrariamente ao que se tende a concluir, a referida cartelização não reconduz ao monopólio, a sua tendência é oligopolística (BERGER, 1985).

220 Essa é uma competição formal, isso não quer dizer que aconteça realmente. No Brasil, por exemplo, ela não acontece: a tradição católica é tão forte que a Igreja está sempre querendo interferir. O acordo que o governo Lula fez com o Vaticano é algo inusitado. Sob o pretexto de o Vaticano ser um Estado constituído, alega-se ser possível fazer acordo; entretanto, o acordo é sobre religião.

${ }^{221}$ Apesar de Berger (1985) ter lembrado que os conteúdos religiosos não são determinados pela preferência do consumidor tout court, ele não aborda especificamente, como faz Bourdieu (1999), a importância dos produtores religiosos nesse processo.
} 


\subsubsection{Dois modelos opostos de assistência religiosa}

\section{- O monopólio da capelania brasileira e a diversidade da aumônerie}

\section{francesa}

A reflexão sobre o modelo de assistência religiosa existente atualmente pode ser ainda mais enriquecedora se confrontada a uma realidade cultural distinta daquela do Brasil, como é o caso da França; pois, apesar de possuírem uma diversidade cultural-religiosa complexa, portam propostas distintas e paradigmáticas no âmbito do serviço religioso hospitalar. Por intermédio de casos específicos, como o do HCFMUSP e o do AP-HP (Assistance Publique Hopitaux de Paris), é possível mediante a visualização das aproximações e diferenças existentes entre esses dois hospitais públicos no que diz respeito ao formato dos serviços religiosos oferecidos colocar em pauta o tipo de assistência religiosa hospitalar oferecida atualmente no Brasil.

O caso francês, ao contrário do brasileiro, tendo em vista a maior organização e abrangência do serviço religioso colocado à disposição do paciente nos hospitais na França, pode servir como uma ferramenta importante para se pensar sobre a qualidade de um mesmo serviço religioso, em toda sua diversidade, no Brasil.

Na França, país secular por tradição, as funções da ciência e da religião estão desde muito tempo bem delimitadas e, talvez por conta disso, o serviço da aumônerie (equivalente à capelania religiosa hospitalar brasileira) está bem distribuído entre as diferentes denominações religiosas ${ }^{222}$. Existe um rol definitivamente amplo e culturalmente rico de serviços religiosos (católico, muçulmano, israelita, protestante, budista, evangélico armênio, ortodoxo russo) nos

\footnotetext{
${ }^{222}$ Mesmo sendo o catolicismo a principal religião estruturante da identidade religiosa francesa - de forma que Bréchon (2000, p. 15) caracteriza a França como "un pays catholique de culture laïque et/ou un pays laïque de culture catholique" - as religiões minoritárias se desenvolvem e tem espaço garantido na sociedade. $O$ fato de não haver a identificação com uma determinada religião faz com que o Estado francês tenha uma atitude mais neutra no trato com as diferentes religiões.
} 
hospitais franceses ${ }^{223}$ que, comparados ao serviço religioso de um hospital da envergadura do HCFMUSP - cuja oferta restringe-se à ordem cristã - suscita o questionamento sobre os motivos de uma tal limitação em um país comprovadamente multirreligioso como o Brasil.

É válido lembrar que a multiplicidade religiosa na França e no Brasil é consequência de um processo histórico diverso, o qual merece atenção. De uma maneira geral, a convivência de cultos distintos no Brasil, como se sabe, está ligada ao próprio processo colonial, ao longo do qual ocorreu o sincretismo de religiões originárias de seus dois grandes elementos étnicos, portugueses e africanos, além daquelas religiões trazidas por imigrantes no final do século XIX e início do século XX (protestantes, budistas, mulçumanos, judeus, etc.); enquanto que na França, majoritariamente católica, a coexistência, nem sempre pacífica, de outras religiões (como o islamismo) está ligada à história mais recente da imigração de indivíduos pertencentes às ex-colônias francesas (Argélia, Marrocos, Senegal, Gabão).

Os hospitais parisienses são claros com relação aos direitos do paciente, dentre os quais inclui o de ter atendimento religioso: "A AP-HP proporciona, deste modo, o livre exercício da prática religiosa em seus hospitais, em conformidade com a lei de 9 de dezembro de 1905 que separa a Igreja do Estado". (Disponível em: <http://www.aphp.fr/site/actualite/mag_droits_malade_cultes.htm> Acesso em: 13/02/07, tradução nossa). Esse livre exercício de culto é o que os representantes dos hospitais chamam, por um lado, de liberdade de consciência dos doentes - "O respeito à liberdade de consciência dos doentes hospitalizados constitui uma regra fundamental" - e por outro lado, apontam como sendo o respeito a uma laicidade aberta. (Disponível em : <http://www.aphp.fr> Acesso em: 13/02/07, tradução nossa).

Em respeito a uma laicidade aberta, todo doente pode, na medida do possível, seguir os preceitos da sua religião. Ministros dos cultos católico, ortodoxo, protestante, muçulmano e israelita estão à sua disposição e a de sua família. Para solicitar a visita de um ministro, basta fazer o pedido ao enfermeiro chefe. (Disponível em : <http://www.aphp.fr> Acesso em: 13/02/07, tradução nossa).

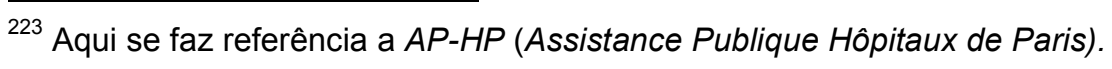


Outro exemplo do apoio dado à diversidade religiosa nos hospitais franceses é a existência do que eles chamam de L'oratoire multiconfessionnel ${ }^{224}$, situado no hospital Bretonneau. Trata-se de um espaço do qual todas as pessoas podem fazer uso, independente da sua crença, quando necessitam de um ambiente reservado para entrarem em contato com o seu "eu" religioso.

O espaço de culto e de recolhimento está localizado num local de 35 $\mathrm{m}^{2}$, completamente neutro [...] um oratório aberto aos que pertencem às três religiões do livro sagrado como também àqueles que não pertencem a nenhuma confissão religiosa. Prova disto, são as inscrições nas paredes: uma passagem da Bíblia (Livro do Exôdo 3, 2-5), uma passagem do Alcorão (a Surata XXV 58) e uma passagem da Torá (o mesmo excerto do Livro do Exôdo, mas em hebraico). As paredes servem também como suporte a molduras vazias, testemunhas da ausência de religião, um convite à reflexão e à meditação ${ }^{225}$. (Disponível em <http://www.aphp.fr/site/actualite/ mag_droits_malade_cultes.htm> Acesso em: 13/02/07, tradução nossa).

A França, assim como o Brasil, é um país de imigrantes, mas lá, ao contrário daqui, as particularidades culturais relativas ao religioso parecem ter um status maior de importância. Muçulmanos, judeus, ortodoxos russos, evangélicos armênios, budistas têm seu espaço de culto garantido e muito bem organizado nos hospitais. No Brasil, onde também existem esses mesmos grupos religiosos e outros mais, como os espíritas kardecistas, os seguidores das religiões afro e de religiões orientais diversas, etc., o que se percebe em relação ao serviço religioso hospitalar é uma garantia que se restringe à Igreja católica e a denominações protestantes. Ou seja, apesar da diversidade religiosa brasileira, observa-se no interior do HCFMUSP o monopólio dos cultos de origem cristã, não existindo dessa forma uma abertura tão grande para a participação de outras denominações religiosas.

Talvez não tenha havido no Brasil o total desenlace entre Igreja e Estado como ocorrido na França, onde é clara a não interferência "legal" da religião nos outros setores da vida, por ter sido o seu lugar bem definido no seio da sociedade, fato este que permite uma maior participação de outras crenças. A religião e os seus representantes conhecem bem o seu papel na sociedade e, no caso em questão, tem noção do seu lugar junto ao hospital. E, ao contrário de se fazer impor, o

${ }^{224}$ Essa obra foi realizada no âmbito de uma encomenda pública fundada sob uma parceria entre o AP-HP e o Ministério da Cultura e da Comunicação Francesa.

225 "L'oratoire multiconfessionnel de l'hôpital Bretonneau" 
ministro religioso do hospital (L'aumônier) deve procurar "se convertir au monde hospitalier", é o que afirma o pastor Hamon, que é aumônier protestante há treze anos. (Disponível em: <http://www.aphp.fr/site/actualite/mag_droits_malade_cultes. htm> Acesso em: 13/02/07).

A ideia de um serviço democrático de capelania religiosa no HCFMUSP, que dê abertura para a participação de diferentes crenças (ainda que essa participação não se restrinja à garantia de um espaço físico), é muito tímida, sendo enxergada somente num futuro bem distante. Neste, a tendência, como acredita AR1, será de cada Igreja ter o seu meio de contato, não necessitando haver um religioso presente diretamente no hospital: "Eu acho que um dia vai chegar [o momento] que - porque hoje tudo você respeita direito do paciente - não vai ter mais essa coisa de ir a todos os leitos: quem quer assistência religiosa chama" (AR1). Nesse formato será necessário haver, segundo o depoente, um espaço onde isso se processe. Isso ocorrerá em oposição à presença fixa de religiosos, pois não há espaço físico - "não vai montar uma galeria de capelas" (AR1) - para que cada um tenha seu representante presente. Além do que, como afirma AR1, semelhante atitude não se faz necessária, visto que existem credos que não têm representatividade entre os pacientes: "Por exemplo, quantos islamitas internam aqui?" (AR1).

A análise comparativa específica dos casos francês e brasileiro, no que se refere à presença religiosa no interior dos hospitais, traz os elementos para reflexão na medida em que há no país europeu em questão uma organização de serviços religiosos intra-hospitalar que não ocorre aqui. Provavelmente tal fato deva-se à forte presença de uma imigração recente, de nacionalidades e culturas diversas, que devido a uma confrontação mais acirrada com a comunidade francesa metropolitana conseguiu colocar em primeiro plano a diversidade religiosa e cultural dos indivíduos, em detrimento da vontade de um único segmento religioso que se encara como o oficial e exclusivo.

Pode-se deduzir, a partir dessa análise comparativa entre esses dois modelos de assistência religiosa, a existência de modos de relacionamento diversos no que diz respeito ao diálogo entre as diferentes religiões no interior dos hospitais. O paralelo entre duas alternativas de atuação paradigmáticas como essas indica que, apesar da pretensa maioria cristã, é possível proporcionar a todos os internos o contato com não importa qual tipo de crença ou religiosidade. Evidencia, ainda, que 
um modelo que contemple a diversidade de opções religiosas não é fantasioso, nem impossível, muito pelo contrário, pois, como se viu, ele é posto em prática num país radicalmente laico como a França. Resta, portanto, refletir a partir da seguinte indagação: Por que no Brasil - considerado um país laico assim como a França - os serviços de assistência religiosa hospitalares não abrem a possibilidade para participação das diferentes crenças que representam a população nacional? 
PARTE III - CAMPO PSIQUIÁTRICO E CAMPO RELIGIOSO: PERCEPÇÕES 
A advertência daquela inscrição me falava cada vez mais claramente: "Só para raros!" "Só para loucos!" Louco eu deveria ser e sem dúvida era um dos "raros", se não aquela voz não me teria alcançado, se não aquele mundo não me teria o que dizer [...]. Compreendi muito bem no íntimo do meu ser o chamado, o convite à loucura, o alijamento da razão, a escapada dos estorvos da convenção para entregar-me a um mundo flutuante $e$ anárquico, da alma e da fantasia. (O lobo da Estepe, Hermann Hesse). 


\title{
5. PERCEPÇÃO NO INTERIOR DO CAMPO PSIQUIÁTRICO
}

\subsection{PATOLOGIA PSIQUIÁTRICA E RELIGIOSIDADE}

\subsubsection{Normal versus patológico: questão cultural versus delírio ${ }^{226}$}

\begin{abstract}
[...] Efetivamente, todos nós, e com muita frequência, somos quase dementes [...] é verdade que não existe o homem normal, de maneira nenhuma; talvez entre dezenas, e pode até ser que entre centenas de milhares, apenas se encontre um, e, ainda assim, em exemplares bastante fracos... (Crime e Castigo, Dostoiévski).
\end{abstract}

O fator religião/religiosidade pode muitas vezes ser associado a um estado patológico momentâneo, o que faz com que tal questão seja colocada em pauta pela equipe de profissionais. O delineamento de uma linha divisória muito bem delimitada pelo corpo médico ${ }^{227}$ ditando as regras do que compreende o âmbito da razão e do que é recorrente no mundo da loucura faz com que haja receio de se tocar no assunto: "[...] como muitos pacientes sabem que eu trabalho, pesquiso na área de espiritualidade, eles falam: 'Eu nunca falei pra nenhum médico, mas pra o senhor eu sei que eu posso falar. Para aquele outro médico, para aquele outro terapeuta, se eu falasse isso, ele ia achar que eu estava louco'" (M1). Segundo Goffman (2005, p. 115), no que diz respeito a uma visão de si mesmo, a ideia da perda de controle de si fundamenta-se em modelos culturalmente aceitos. Ou seja, dependendo da cultura $^{228}$, pode haver diferença "na quantidade de fantasia e estímulo para as visões de si mesmo, o que leva a diferentes proporções de auto-avaliação".

\footnotetext{
${ }^{226}$ Psiquiatras (6 bi-posicionados, 16 neutros, 2 mono-posicionados) e enfermeiros (6 neutros, 1 biposicionado) falam sobre a questão.

${ }^{227}$ Segundo Szasz (1979, p. 17), "na realidade, muitos conceitos psicossociais são definidos segundo as intenções, interesses e valores de seus próprios conhecedores. Virtualmente todos os conceitos psiquiátricos atuais são desse tipo".

${ }_{228}$ O autor faz referência ao que ele chama de "algumas subculturas na sociedade norte-americana". (GOFFMAN, 2005, p. 115).
} 
A percepção de "perder a cabeça" se baseia em estereótipos culturalmente derivados, e socialmente impostos, quanto à significação de alguns sintomas - por exemplo, ouvir vozes, perder a orientação espacial e temporal, sentir-se perseguido - e muitos dos mais espetaculares e convincentes de tais sintomas em alguns casos significam, psiquiatricamente, apenas uma perturbação emocional temporária em situação de tensão, por mais aterrorizantes que sejam para a pessoa nesse momento. (GOFFMAN, 2005, p. 115).

O que é denominado "doença mental"229 pode ser manifestado algumas vezes mediante excessiva religiosidade, acredita a maior parte dos informantes. Pode ocorrer de uma pessoa ficar religiosa sem que seja na verdade uma escolha pessoal, mas algo relacionado ao quadro patológico (M22). A doença, então, pode afetar a escolha que a pessoa realiza e, por vezes, é justamente isso que acontece: "o sintoma da doença faz com que ela fique religiosa"230. Entretanto, segundo M22, essa não é uma religiosidade, ao contrário é um sintoma da doença: "Na medida em que a gente tira a doença ${ }^{231}$ e faz com que a pessoa tenha a liberdade de escolha dela, aí sim eu quero que ela tenha os valores políticos, sociais e inclusive religiosos" (M22). Nessa perspectiva, julga-se importante procurar detectar de que lado a religião está naquele momento, de uma escolha racional ou da doença - "É muito importante você conversar profundamente e ver se aquilo é sintoma ou aquilo são os valores da pessoa. Isso existe. Infelizmente, em psiquiatria, tem muito disso. Como a gente fala o seguinte: Da doença eu trato, dos valores da pessoa eu apenas converso" (M22).

Entretanto, cuidar do delírio tout court e não proporcionar algo em troca pode simplesmente impingir uma cura, já que se retira uma base de sustentação com a qual o sujeito familiarizara-se e deixa-se um vazio: "Enquanto ele estava com

\footnotetext{
${ }^{229}$ Ao longo deste trabalho os termos doente mental/doença mental serão utilizados entre aspas, pois parece uma definição arbitrária, muitas vezes atrelada a preconceitos e interesses, e por isso, propensa a cometer abusos. De acordo com a perspectiva de Szasz (1978, p. 15), a própria arbitrariedade do conceito de doença mental já mostra muito o engodo e a farsa que estão por trás de uma ideologia que tem como princípios servir a uma necessidade moral, a qual tem na sua base certa permissividade. Esta concebe que "membros 'sadios' da sociedade lidem, como quiserem, com os seus semelhantes que são categorizados como 'insanos', livrando-se assim "das coerções corretivas do diálogo" (SAZSZ, 1978, p. 16, aspas do autor). Para esse autor, os psiquiatras lidam com problemas morais, os quais não podem ser resolvidos mediante métodos médicos que desprezam "explicações do comportamento humano em termos de liberdade, escolha e responsabilidade". (IBIDEM, p. 20).

${ }_{230}$ M22 ilustra tal questão com o caso de uma paciente: "Ela está recebendo uma voz na cabeça: 'Olha, é Deus que está falando. Vai lá e mata a sua filha que nem fez o Abraão'. Então, o paciente vai lá e mata".

${ }^{231}$ Segundo Birman (1978b, p. 209 apud SILVA, 2001, p. 159), "a extirpação sintomática, qualquer que seja o procedimento técnico adotado, revela a presença de uma representação cirúrgica [...]".
} 
aqueles delírios até esdrúxulos era uma vinculação dele com o mundo. Na medida em que deu remédio e acabou com aquela absurdidade, mas também não devolvemos nada, o paciente se matou. Por isso que a gente precisa dar coisas. A religião seria um complemento" (M22).

Szasz (1978), ao comparar a crença em feitiçaria (a perseguição a feiticeiras) e a crença em "doença mental" (a perseguição a "doentes mentais"), vê tanto na religião quanto na psiquiatria - que ele chama psiquiatria institucional, onde o paciente não é internado voluntariamente - duas formas de ideologia da intolerância. M24 faz referência, de um lado, à quantidade expressiva de mulheres e homens que foram queimados pela Santa Inquisição e que eram, na verdade, esquizofrênicos e, de outro lado, à elevada quantidade de "loucos" que atualmente são tomados nas igrejas por endemoniados (M24). O depoente, ao trazer à tona essas reflexões, inclui a religião e não a psiquiatria na modalidade negativa pensada por Szasz, para quem com o declínio da Igreja e da interpretação religiosa do mundo, ocorrida no século XVII, o complexo inquisidor-feiticeira foi dissipado, e em substituição, surgiu o complexo alienista-insano (SZASZ, 1978). Uma explicação possível para a passagem de um complexo ao outro reside, muito provavelmente, na problemática moral, a qual está na base tanto das intervenções psiquiátricas - o que não é voluntariamente acatado - quanto das intervenções religiosas (IDEM, 1979). Segundo M18, existe uma relação entre medicina e religião no sentido de ambas possuírem em comum, em termos conceituais, um "cunho de valores morais bastante importante" (M18). De acordo com o depoente, tanto o médico como o religioso incorporam tais valores morais "de uma maneira até inconsciente, natural" e os transforma em uma parte importante da sua vida (M18). Evidentemente não se pode deixar de apontar o quanto o habitus corresponde a tais comportamentos introjetados.

Ao ser nomeado, ipsis litteris, como "médico da alma" (M3), o psiquiatra é chamado a um papel que, embora muito voluntariosamente desempenhado por religiosos, o coloca numa situação delicada de ter de entrar em contato com os demais aspectos do sujeito, que não apenas o biológico. Num determinado momento, que Foucault vai chamar de "novo mundo asilar" (mundo moral que 
castiga) $)^{232}$, a loucura deixa de ser vista como um fenômeno relativo simultaneamente ao corpo e à alma, passando a ser vista em relação apenas à última: "A loucura tornou-se um fato que concerne essencialmente à alma humana, sua culpa e liberdade; ela inscreve-se doravante na dimensão da interioridade ${ }^{233}$; e por isso, pela primeira vez, no mundo ocidental, a loucura vai receber status, estrutura e significação psicológicos" (FOUCAULT, 2000, p. 83, destaque nosso).

A postura dos psiquiatras frente à loucura é um pouco opaca dada a forma como eles acabam por se colocar em relação a ela - "é uma coisa meio assim: eles cuidam do paciente, mas é como se de repente aquilo não pudesse acontecer com eles" (M11). Essa atitude é prova prima facie de que o psiquiatra coloca-se, sem questionamentos, numa condição de superioridade que o torna imune de ser eivado pela loucura e suas quimeras. Entretanto, a sabedoria dos pacientes pode ser considerada superior à dos médicos ao se levar em conta que aqueles possuem mais informações sobre esses profissionais e não o contrário, porquanto "a posição que o profissional ainda ocupa no mundo do teatro social eles já ocuparam, enquanto que o inverso não é verdadeiro" (BAZZO, 2000, p. 28). Ou seja, o louco já foi "normal" e já experimentou o seu inverso; portanto, tem mais propriedade, mais conhecimento do que o psiquiatra que não experenciou o status de louco e que por conta disso não possui a vivência (na pele), apenas o conhecimento do observador, do cientista.

Essa divisão razão/loucura contaminada de preconceitos e de arbitrariedades sugere que, ao guiar-se conforme seus desejos - em contraposição às regras do bom convívio -, o sujeito quebra um protocolo de comportamento que postula o que é certo ou errado, colocando em risco a manutenção da ordem social.

\footnotetext{
${ }^{232}$ Que data do novo modelo proposto por Pinel, o qual retoma técnicas antigas "num contexto puramente repressivo e moral". (FOUCAULT, 2000, p. 83). Nesse sentido, segundo Szasz (1979, p. 33), "a libertação do paciente mental da masmorra [atribuída a Pinel] não foi de modo algum uma conquista psiquiátrica. Foi uma conquista moral". Ou seja, tal empreitada deve ser encarada antes como uma reforma social "do que como uma inovação no tratamento médico".

${ }^{233}$ Esse pode ser considerado não apenas um dos exemplos possíveis de semelhança entre psiquiatria e religião como também um dos elementos que explica as lutas travadas entre os dois campos na busca pelo monopólio (que é em torno da interioridade, da alma humana). Tanto que se percebe até hoje a intromissão de religiosos no sentido de atribuírem a questões psiquiátricas o status de possessão demoníaca bem como a atribuição, feita pelos médicos, de neurose ou psicose a comportamentos religiosos.
} 
Entretanto, como é possível fixar aonde termina o normal e começa o patológico ${ }^{234}$ ? Canguilhem (2006) alerta quanto ao fato de não ser o normal um conceito estático ou pacífico, ao contrário trata-se de concepção dinâmica e polêmica. Essa é uma questão controversa e que coloca os psiquiatras, principalmente em contraposição à presença religiosa, na medida em que os delírios, o comportamento patológico frequentemente vem associado a questões de ordem religiosa. Segundo E4 é muito subjetiva essa questão, pois como é possível dizer o que é normal ou anormal “segundo o poeta Caetano Veloso: 'De perto ninguém é normal'. Parte por aí” (E4). Podem acontecer, por exemplo, casos em que um paciente considerado psicótico mantém, entretanto, um diálogo coerente, o que faz com que o profissional tenha dúvidas se quando ele fala algo sobre espiritualidade está delirando ou não. Até mesmo porque psiquiatras que estudam 0 assunto concluíram quanto à possibilidade de "algumas pessoas terem mediunidade" (E4). Por isso mesmo, E4 considera que não dá pra descartar as coisas (E4). Ou seja, não se deve desconsiderar as possibilidades de compreensão que existem sobre um mesmo fato.

Partir de uma norma que é resultante da média com o intuito de estabelecer comparações não parece recomendável, deve-se ao contrário ter como fundamento as condições do indivíduo que está sendo examinado (CANGUILHEM, 2006, p. 135). Segundo o autor, há uma relação entre o conceito empírico de doença e o conceito axiológico da doença: "Não é, portanto, um método objetivo que qualifica como patológico um determinado fenômeno biológico. É sempre a relação com o indivíduo doente, por intermédio da clínica, que justifica a qualificação de patológico" (IBIDEM, p. 177).

Se o normal não tem a rigidez de um fato coercitivo coletivo, e sim a flexibilidade de uma norma que se transforma em sua relação com condições individuais, é claro que o limite entre o normal e o patológico torna-se impreciso. [...] A fronteira entre o normal e o patológico é imprecisa para diversos indivíduos considerados simultaneamente, mas é perfeitamente precisa para um único e mesmo indivíduo considerado sucessivamente. Aquilo que é normal, apesar de ser normativo em determinadas condições, pode se tornar patológico em outra situação, se permanecer inalterado. O indivíduo é que avalia essa transformação porque é ele que sofre suas

${ }^{234}$ Contrariando o pensamento dominante na sua época, segundo o qual a distinção entre normal e patológico era de natureza quantitativa, Canguilhem defendia a ideia de que se tratava de dois fenômenos qualitativamente diferentes e opostos. 
conseqüências, no próprio momento em que se sente incapaz de realizar as tarefas que a nova situação Ihe impõe. (CANGUILHEM, 2006, p. 135, destaque nosso).

Como definir a doença mental? Normalmente os critérios utilizados levam em consideração "o afastamento com relação a uma norma estatística de comportamento" (SZASZ, 1978, p. 27). O sujeito "suposto louco" não tem muitas opções quando diagnosticado, ou ele reconhece o seu estado ou a sua própria "incapacidade para 'reconhecer' que está louco é considerada como sinal de sua doença" (IBIDEM, p. 16, aspas do autor). Quando Szasz (1978, p. 21) afirma que, assim como não existiam as feiticeiras, os doentes mentais não existem, isso não quer dizer que não exista "a conduta pessoal apresentada pelas pessoas classificadas como mentalmente doentes". O fato é que "o conceito de doença mental serve, no mundo contemporâneo, à mesma função social que tinha o conceito de feitiçaria no fim da Idade Média", ou seja, a crença na doença mental tem as mesmas consequências morais e políticas que a crença na feitiçaria (IBIDEM, p. 19): "Na realidade, rotular os indivíduos que se sobressaem, ou que são incapacitados por problemas da vida, de 'doentes mentais' apenas impediu e retardou o reconhecimento da natureza política e moral dos fenômenos para os quais se dirigem os psiquiatras" (SZASZ, 1979, p. 35).

Existe um posicionamento recorrente tanto entre os psiquiatras biposicionados quanto entre os psiquiatras mono-posicionados e os neutros/ambíguos, que é relativo ao papel ocupado pela religião junto ao doente. Quando inquiridos sobre o papel exercido pela religião na vida do paciente - seja sob a forma do atendimento religioso, seja no sentido do paciente apresentar esse tipo de questão para o seu médico -, a maior parte dos psiquiatras, amiúde, concordavam em que seria necessário haver muita cautela quanto a essa temática. Isso porque, no contexto psiquiátrico, ela poderia aparecer quase como um epifenômeno da patologia mental ${ }^{235}$. Mentalidade, por vezes, associada, como já visto em outro momento, à visão freudiana que encara a religião como uma fonte de neurose (vide "Estudos em saúde e espiritualidade").

235 Alguns profissionais não assumem diretamente esse posicionamento, ao contrário, fazem referência ao que normalmente acreditam que é colocado em prática pela maior parte dos colegas de profissão. 
Por isso, os psiquiatras "fogem desse tipo de conversa" (M24), que é um tanto quanto enevoada (M24) na prática médica, onde profissionais considerados "radicais" (M24) "falam que qualquer tipo de religião é uma forma de psicose/delírio" (M24). Ou seja, os comentários sobre a questão religiosa "normalmente são pejorativos", principalmente nas questões tangentes ao que é religioso em si e o que é transtorno psiquiátrico (M21). Assim, é comum ouvir no ambiente hospitalar pareceres desfavoráveis, pois a realidade normalmente leva a crer que na patologia do paciente entrou a questão da religião (E10): "Os médicos são assim: 'Ah, tá vendo! São fanáticos! Foi a igreja que fez com que ele se perdesse”" (E2); "Ah, é delírio! É fanático". (E9). Desse modo, ao fazerem ressalvas, afirmando que "depende do momento" ${ }^{236}$, psiquiatras neutros retraduzem, ou seja, não estão de todo fechados às possibilidades do contato com o campo religioso.

Seria incúria por parte do profissional dessa área - acredita a maior parte dos depoentes - não estar atento ao perigo que pode representar um comportamento religioso. Tal comportamento pode ser sinônimo de delírio (“Depende da patologia porque às vezes o paciente está delirando, por exemplo, com conteúdo religioso e pode ser complicado. Talvez em uma determinada fase o melhor seja afastar o paciente dessa parte religiosa porque isso seria prejudicial" M2), de mania ("No mau sentido: a mania, por exemplo, você só fica alimentando a mania, este seria um efeito nocivo" - M4). Invariavelmente irá depender da patologia do paciente (esse é o Leitmotiv no discurso dos psiquiatras), já que muitas vezes a religião pode ser um sintoma da doença (outro Leitmotiv): "Na maioria das vezes o psiquiatra tende a ver o paciente que fala sobre assuntos religiosos como um aspecto da doença do paciente do que como algo religioso em si, mas depende muito da história do paciente" (M12). Assim, não é raro ouvir afirmações que se refiram à: Interface entre psicopatologia e religião (M3, M4); Religião como fruto da doença (M25); Incidência de pacientes místicos na psiquiatria que acham que são personagens religiosos importantes (E6, E11); Religião como sintoma da doença (M9); Depende da patologia, do diagnóstico (M5, M6, E2).

Vai depender da patologia do paciente. Um paciente com esquizofrenia que começa a falar muito de religião pode ter algum link/elo com o quadro dele. Mas eu acho que é o meio-termo. Em

${ }^{236}$ Psiquiatras utilizam essa expressão quando inquiridos sobre a assistência religiosa junto ao paciente psiquiátrico. 
alguns quadros mais graves o médico pode gerenciar, mas na maioria das vezes, tirando os quadros extremos de esquizofrenia, por exemplo, acho que vale a pena chamar um profissional [da religião] para interceder, para escutar. (M5).

$\mathrm{Na}$ verdade vai depender do paciente. Acho que para alguns pacientes, sim. Para aqueles pacientes que já são religiosos de base, sim. Mas a gente tem que lembrar também que tem um monte de doença psiquiátrica que acaba tendo um componente religioso que não tem a ver com religião. Um delírio religioso, alguma coisa assim. (M6).

Existem doenças psiquiátricas cujos sintomas, pelo menos alguns deles são: hiper-religiosidade, um discurso religioso bastante proeminente, mas de toda forma, mesmo sendo sintoma ou não, faz parte da realidade psíquica do paciente. Então interfere. Vai interferir de qualquer jeito, seja de uma forma positiva ou negativa. Então, eu acho que o médico tem que ficar atento. Não é simplesmente falar: isso é um sintoma. Pode até ser eminentemente um sintoma, mas tem uma influência sobre a pessoa. Eu acho que é uma área muito importante da vida do sujeito que não dá pra desprezar, mesmo se eventualmente sofrer a influência da patologia. (M14).

Tem muitos [pacientes] que chegam aqui totalmente místicos. Chegam orando em cima da cabeça de outros pacientes. Tem uns que chegam dizendo que são Jesus Cristo. Então, a fé sempre está presente. De uma maneira ou de outra a religião perante eles está presente. Uns pensam que são Jesus Cristo, outros: por que Deus os abandonou? Sempre está presente [...] Às vezes a parte religiosa deles está tão aflorada que os pensamentos deles passam a ser incoerentes. (E11).

A visão que coloca a religião, a princípio, como patológica no sentido de caracterizá-la como sintoma da doença pode ser inexpressiva em relação à totalidade dos casos ("Existem situações em que transtornos mentais podem assumir sintomatologias religiosas. Pode acontecer, mas isso é a exceção. A média da população não é assim. Na maioria dos pacientes" - M1). Entretanto, a postura que enxerga na religiosidade um sintoma da doença reverbera a tendência (muitas vezes dissimulada) de patologizar o que não se conhece ou o que se considera como culturalmente inadequado. A prática psiquiátrica, como mostrou Costa (2007), esteve relacionada, em outro contexto, à vulnerabilidade a certos preconceitos culturais e, vinculada a isso, à não delimitação do campo psiquiátrico (o que fazia 
com que o psiquiatra confundisse problemas psiquiátricos e problemas culturais $)^{237}$. Ou seja, há um histórico e uma inclinação do campo psiquiátrico nessa direção.

Práticas culturais diferentes não necessariamente serão alvo de empatia, o que pode causar dificuldades no sentido de o psiquiatra ignorar ou patologizar, já que ele "não compreende bem essa vivência" (M1). Assim um paciente que personifica uma pessoa (os exemplos de Jesus Cristo) é rotulado de psicótico ${ }^{238}$. Ocorre, pura e simplesmente, que "quanto mais insuportável for publicamente a personificação de uma pessoa, e quanto mais tenazmente ela se agarrar a essa personifição a despeito das tentativas do outro em rejeitá-la" (SZASZ, 1979, p. 209), maiores serão as chances de ser considerada, ou melhor, rotulada como louca ou psicótica. Pode muito facilmente ocorrer, nos casos aqui estudados, um encontro entre experiências de vida totalmente distintas (médico e paciente), as quais são passíveis de serem recebidas com aversão, preconceito. A consciência das diferenças existentes é necessária para que o profissional tenha cuidado "com o julgamento pessoal" (M15) e esteja atento para o que é valor para si próprio sem esquecer os valores que o paciente carrega consigo ${ }^{239}$.

Há os que reconhecem a importância dos contextos antes de avaliar o que é delírio, o que é patológico; no meio psiquiátrico pode haver esse tipo de atuação (considerada infrequente). Dentre esses, há até mesmo os que procuram informarse sobre um tipo de religiosidade ${ }^{240}$ que pode ajudar a entender manifestações culturais específicas, as quais podem ser confundidas com patologias: "Às vezes tem paciente que age de uma maneira que para a gente é estranho, mas foi a doutrina religiosa dele que levou àquilo" (E2). Conhecer a religião, levar em

\footnotetext{
${ }^{237}$ Isso aconteceu mesmo após a revolução propiciada por Juliano Moreira, figura que, embora tenha contribuído na implantação de um sistema psiquiátrico coerente, esteve preso a preconceitos culturais da época.

${ }^{238}$ A atitude delirante do paciente pode ser vista, dependendo do registro em que é lida, como verdadeira. Se assim for entendida, segundo Cooper (1989, p. 44), "valorizar-se-á a afirmação do psiquiatra americano, que definiu o delírio como uma idéia verdadeira mantida pelo paciente, com a qual o psiquiatra se ilude a si próprio ao aceitá-la literalmente. Mas o contrário do literal não é necessariamente o metafórico. A realidade existencial de uma pessoa transcende esta oposição" (destaque nosso).

${ }^{239}$ Segundo M24, as crenças do profissional podem interferir - "Um médico muito ateu pode achar que não: 'Isso continua delírio, vou aumentar o remédio'. O médico que acha que não: 'Isso pode ser a crença dela' e já manteria o remédio aí. A grande questão é nos momentos limítrofes. Ninguém tem dúvida que tem que medicar quando a pessoa está lá sofrendo, inadequada, falando que precisa fazer sexo com espírito na enfermaria. Mas quando há melhora, a gente fica em dúvida" (M24).

240 Segundo um paciente entrevistado, esse tipo de psiquiatra - que fala sobre religião com o paciente - é "mosca branca" (P6), ou seja, não existe.
} 
consideração o contexto cultural/religioso para saber diferenciar patologia de religiosidade (M21, M3, M8, M16) são atitudes consideradas relevantes ${ }^{241}$.

Uma pessoa que está tendo o que eles chamam de emergência espiritual, está emergindo, surgindo um potencial espiritual nessa pessoa, por exemplo, um médium começando a se desenvolver, pode ficar confuso, achar que aquilo ali é loucura e ter sofrimento com aquilo. Isso também seria um problema espiritual/religioso, mas não um transtorno mental. (M1).

É importante, eu acho, você conhecer as religiões. Às vezes você acha que aquilo é psicótico, mas dentro daquela religião aquilo faz sentido e é compartilhado por outras pessoas. Desde aquele momento deixa de ser psicótico, deixa de ser anormal. (M7).

Eu acho que faz parte do nosso aprendizado a gente saber diferenciar quando aquilo é uma crença religiosa e quando é um delírio de fato. Acho que esse é um desafio muito interessante na prática médica e eu tento exercitar isso aqui. (M15).

A gente tenta estudar. Através disso a gente sabe que em algumas religiões a alucinação é normal. Por isso que eu sei...o pai de santo fala que na messiânica é normal você ter visões, essas coisas. Isso a gente tem que saber. (M17).

Eu acredito que ele mesmo deve resolver essa situação porque cabe ao psiquiatra que está atendendo uma pessoa diferenciar se a religiosidade daquele paciente é patológica, é influenciada por um delírio que ele está vendo Deus, por uma alucinação ou a religiosidade dele faz parte do homem em si. Então, ele é a pessoa mais importante nesse momento pra saber se aquela religiosidade é sintoma de uma doença ou faz parte dos valores daquela pessoa. Se for sintoma, ele tem que tratar. E se for os valores daquela pessoa, ele tem que saber conversar. (M22).

Como medir o limite entre normal e patológico no que diz respeito ao comportamento religioso? A arbitrariedade presente em tal julgamento coloca a importância de deixar de lado conceitos fechados, ideias obtusas. Alguns profissionais chegam a admitir a propensão a cometerem-se erros nesse tipo de julgamento: "Vacilos sempre pode ter, a gente tá propenso a cometer erros, vacilos, comida de bola, essa propensão, esse risco aumenta quanto maior for o desconhecimento ou o preconceito em relação a isso" (M3). Como afirma Becker

${ }^{241}$ A necessidade de levar em consideração tanto as questões biológicas quanto as culturais de fenômenos relacionados ao desvio da norma fez com que a psiquiatria e a antropologia iniciassem uma parceria constituindo dessa maneira o campo da etnopsiquiatria. Nesse sentido, seria possível entender, mediante a combinação de categorias antropológicas e biológicas, um normal e um patológico próprios a determinadas culturas. 
(2008, p. 19) não há um consenso quanto ao que constitui um pensamento saudável, até mesmo entre os psiquiatras é difícil encontrar uma definição que os satisfaça. Dificilmente tem-se em mãos, tal como acontece nos casos da aceitação dos "critérios de saúde para o organismo", uma definição "que as pessoas aceitem em geral" no caso de comportamentos considerados desviantes.

Assim como as normas podem variar culturalmente no que diz respeito a contextos diversos, elas podem estar relacionadas, de acordo com Becker (2008), numa mesma sociedade a grupos plurais que competem para fazer reconhecer a sua visão de mundo. As normas assim se tornam relativas, no sentido de que o que é considerado válido para certos grupos não o é para outros. Automaticamente, ao se criar uma norma, criam-se também desviantes ${ }^{242}$. Levando em consideração que não há normas que sejam universais ou que estejam isentas dos interesses de determinados grupos, a sua simples criação implica necessariamente a criação de desviantes. Por serem criações de grupos sociais específicos, os quais estão inseridos em sociedades modernas complexas - altamente diferenciadas ao longo de linhas de classe social, étnicas, ocupacionais e culturais -, as regras podem variar em função disso.

[...] grupos sociais criam desvio ao fazer as regras cuja infração constitui desvio, e ao aplicar essas regras a pessoas particulares e rotulá-las como outsiders. Desse ponto de vista, o desvio não é uma qualidade do ato que a pessoa comete, mas uma conseqüência da aplicação por outros de regras e sanções a um 'infrator'. O desviante é alguém a quem esse rótulo foi aplicado com sucesso; o comportamento desviante é aquele que as pessoas rotulam como tal. (BECKER, 2008, p. 22, destaque e aspas do autor).

O fato é que normalmente a incerteza (e com esta a ausência de uma classificação) é pouco tolerada pelas pessoas, as quais teimam em que o mau comportamento "seja classificado como pecado ou como doença" (SZASZ, 1979, p. 46). Na realidade, se bem é possível notar, no momento em que a sociedade (na pele dos psiquiatras) estabelece uma regra de saúde mental, ela cria, classifica uma classe de indivíduos mentalmente doentes. Assim como as feiticeiras na Idade

242 "Venho usando o termo 'outsiders' para designar aquelas pessoas que são consideradas desviantes por outras, situando-se por isso fora do círculo dos membros 'normais' do grupo. Mas o termo contém um segundo significado, cuja análise leva a um outro importante conjunto de problemas sociais: 'outsiders', do ponto de vista da pessoa rotulada de desviante, podem ser aquelas que fazem as regras de cuja violação ela foi considerada culpada". (BECKER, 2008, p. 27, aspas do autor). 
Média, como lembrou Szasz (1978), não optavam pelo papel que Ihes era atribuído, o mesmo ocorre em relação ao "doente mental", que não escolheu tal papel. Nesse sentido, é possível reparar que a degradação psiquiátrica atua muitas vezes no sentido de atender "a importantes necessidades dos membros 'mentalmente sadios' do grupo" (IBIDEM, p. 21). Segundo Szasz (1979, p. 10), uma pessoa pode considerar-se doente, mas dificilmente vai achar-se "mentalmente doente", este tipo de rótulo normalmente é sugerido por outra pessoa, o que faz com que, ao contrário das doenças corporais, as doenças mentais sejam tratadas sem o consentimento das pessoas: "Uma pessoa pode sentir-se triste ou radiante, insignificante ou grandiosa, suicida ou homicida, e assim por diante, mas provavelmente não vai classificar-se de mentalmente doente ou insana".

Desse modo, colocam-se sob suspeita atitudes que poderiam ser tidas como naturais em outros contextos: "Às vezes é duvidoso ${ }^{243}$. Um paciente que reza um pouco além do costume pode ficar no limite entre o normal e o patológico, mas geralmente a gente percebe" (M2). Cabe ao psiquiatra distinguir o que é "um discurso religioso ou patológico, dentro da psicopatologia do paciente". Em alguns casos, seria negativo colocar uma pessoa religiosa perto de alguns pacientes ${ }^{244}$, pois "só alimentaria o quadro". (M4). Na verdade, para ser considerado doente mental, basta não estar de acordo "com regras de saúde mental psiquiatricamente definidas e impostas" (SZASZ, 1978, p. 27). Isso é ser considerado divergente social e a divergência social (expressão considerada insatisfatória para ser utilizada ${ }^{245}$ ) "é um termo que abrange vasta categoria" (IBIDEM, p. 27). Entretanto, vale lembrar que se os papéis são artefatos sociais, a questão complica-se ainda mais, já que a divergência no papel "só tem sentido no contexto de leis e costumes sociais específicos" (IBIDEM).

\footnotetext{
243 "Oscilava entre a crença de que aquilo fosse verdade e a suspeita de que fosse loucura pura e simples" (Lima Barreto, O triste fim de Policarpo Quaresma, 17. ed. São Paulo: Ática, [s.d.]).

${ }^{244}$ Segundo M4, é comum "pacientes que têm mania terem discurso religioso querendo curar todo mundo".

${ }^{245}$ De acordo com Szasz (1978, p. 26, aspas do autor), as palavras têm vida própria, por isso ele sempre procurou evitar o uso do termo "divergentes" para se reportar às feiticeiras e aos doentes mentais. Segundo o autor, "por mais que os sociólogos insistam que o termo 'divergente' não diminui o valor da pessoa ou do grupo que são assim classificados, a suposição de inferioridade está presa à palavra". Quanto a isso, o autor atribui culpa aos sociólogos, os quais "descrevem os viciados em drogas e os homossexuais como divergentes, embora nunca empreguem o termo para falar dos vencedores de prêmio Nobel ou de campeões olímpicos".
} 
Como caracterizar um delírio? Talvez se esteja voltando àquela questão recorrente relativa ao par de opostos (não tão opostos como querem muitos) que inquire sobre os limites de fronteira tão tênue. Koenig ${ }^{246}$ (2007) afirma haver um consenso quanto à existência de critérios específicos que podem auxiliar a distinguir "a pessoa mentalmente doente com psicose da pessoa religiosa e devota que tem experiências místicas".

A pessoa religiosa tem insight na natureza extraordinária dos seus relatos, normalmente faz parte de um grupo de pessoas que compartilha as suas crenças e experiências (culturalmente apropriado), não tem outros sintomas de doença mental que afetem o processo de seus pensamentos, é capaz de manter um trabalho e evitar problemas legais, não causar danos a si mesma e, normalmente, tem resultado positivo com o passar do tempo. Porém, claro que há sempre a possibilidade de que uma pessoa mentalmente doente (até mesmo aquelas com doença psicótica) tenha crenças religiosas e experiências místicas que sejam culturalmente normativas e possam, de fato, ajudar a mais bem lidar com a sua doença mental. (KOENIG, 2007).

O fato é que é colocado ao conhecimento dos profissionais um conjunto de fatores que, se alcançados, os auxiliará a decidir se o paciente tem delírio. Tem que "ter muito olho" (M3) para saber onde está a fronteira entre a religião-delírio e a religião-cultura/valor, pois assim como pode "estar escarrado" (M3) quando a religião aparece de forma patológica pode também o limite ser tênue (M3, M15, E9). Por isso, para além da rotulação de "doença", é necessário captar, em primeira instância, se o que o profissional "oferece pode ajudar o paciente ou não, se ele sofre ou não" (M15). Essa ponderação deve abrir caminho para as demais reflexões que possam vir a ser feitas.

Para você dizer que a pessoa está doente, você não tem uma coisa apenas, tem uma série de coisas que configuram a doença. Se a pessoa meramente disser especificamente "tive a impressão que tive um chamado de Deus", alguma coisa assim, não significa necessariamente que ela tenha uma doença psiquiátrica. Mas se isso vem com outras coisas, aí você vai ter uma chance bem maior de que isso seja uma doença mental. Não dá pra dizer: "É isso". Não é uma coisa sim ou não. Em algumas vezes até se misturam. Por

246 Psiquiatra norte-americano reconhecido no meio dos psiquiatras bi-posicionados do IPQ, estudioso do impacto da espiritualidade na saúde, fundador do Center for the Study of Religion/Spirituality and Health da Universidade de Duke, na Carolina do Norte, EUA. Dentre as suas publicações traduzidas para o português está o livro "Espiritualidade no cuidado com o paciente" (2005) (ver referência bibliográfica ao final). 
exemplo: eu tenho uma paciente que a família considera que ela é médium, só que ela também tem alucinações. (M6).

Eu já atendi paciente que abandonou a escola... um rapaz jovem que abandonou a escola, todos os compromissos sociais dele e passava o dia deitado na cama porque ele achava que Deus mandou uma mensagem para ele e ele estava em um estado de êxtase religioso. Esse é um paciente que gerou altas discussões aqui porque eu falando assim é difícil da gente ter uma compreensão exata do caso, mas na hora deixou muitas dúvidas se aquilo era simplesmente uma crença religiosa ou se tratava de um estado psicótico, como a gente costuma chamar. Esse foi um paciente em que eu mais tive contato com a dificuldade que é você delimitar até onde é crença e até onde a coisa extrapolou para o incompreensível. Que é o que a gente tenta diferenciar pra dizer se a coisa é patológica ou não. (M15).

Eu tinha uma paciente que me contava que tinha visto Deus, o diabo e aí ela começou a ficar muito mística. Ela sentia o espírito das pessoas, a alma das pessoas. Dentro da psiquiatria e das condutas que são tomadas no hospital, ela foi tomada como uma paciente com delírios místicos, com quadro psicótico e muitas vezes se for levar em consideração talvez outros segmentos da sociedade como talvez alguns padres, outros religiosos, podem achar outra coisa dessa pessoa. (M24).

Uma medida utilizada para saber se é delírio ou não é verificar se a religião fazia parte da vida do paciente antes da doença. Segundo M24, os psiquiatras da "velha guarda" normalmente utilizam o seguinte medidor: "Se [a religião] não fazia parte da vida do paciente antes de isso acontecer [de começar os delírios], provavelmente é uma doença" (M24). Concordam com esse procedimento M9 e E1, que alertam respectivamente: "Quando a pessoa não é religiosa, então ela tem outros sintomas mais uma hiper-religiosidade, por exemplo"; "Tem que ver se ele está com princípio religioso de um tempo para cá ou se ele já frequentava uma igreja". Segundo M17, o paciente, dependendo de sua patologia, pode entrar "em uma fase onde ele tem uma dúvida sobre a vida e inclusive a religião" (M17), daí inicia-se um processo onde ocorre a passagem por várias religiões, sendo que em cada uma delas ele pode viver um período de fervor religioso (M17).

Como avaliar a situação do sujeito que não se enquadra nas normas sociais? Ele pode ser considerado anormal? É conveniente pensar sobre a arbitrariedade contida nessa definição. Por isso, considera-se necessário o cuidado no uso de categorias que costumeiramente são referidas para abordar este tema. Assim como Velho (2003, p. 11), acredita-se indispensável "superar a camisa-deforça de preconceitos e intolerância". Se se permanecer no nível do senso comum, 
muito provavelmente o comportamento desviante ${ }^{247}$ acaba por ser "remetido a uma perspectiva de patologia" (VELHO, 2003, p. 11). Na concepção médica em tela, o que ocorre comumente é o sujeito desviante ser entendido a partir do binômio normal/patológico, o qual remete a um mal "localizado no indivíduo". No interior do panorama médico mais amplo, há os que acreditam ${ }^{248}$ haver a mobilização de mecanismos socioculturais na identificação do desvio.

A questão do delírio pode ser vista sob a ótica do social - faz-se, assim, a inflexão "de uma patologia do indivíduo para uma patologia social" (IBIDEM, p. 14). Dessa feita, sobressai a ideia de “uma sociedade 'doente', 'instável' e mal-integrada, em situação de anomie ${ }^{249}$, [a qual] representaria um desvio [...] de um ritmo e funcionamento 'normais'. É óbvia a analogia organicista” (IBIDEM, aspas e destaque do autor). Nessa concepção vê-se avultar a questão da anomie em oposição à integração da sociedade. O caráter "conservador", atribuído normalmente a uma perspectiva como a anterior, reside não somente na questão de dar ênfase à harmonia e ao equilíbrio social (que no final das contas parecem ser tratados como inevitáveis); mas também na apresentação de uma "estrutura social não problematizada", onde o foco é "um sistema social já dado, 'funcionando'” (IBIDEM, p. 15 , destaques e aspas do autor).

A postura dos interacionistas simbólicos frente à questão do comportamento desviante consegue ir além da teoria da anomie, na medida em que - e já foi possível apreciar isso com Becker (2008) quando trata dos outsiders - defendem a ideia de que "não existem desviantes em si mesmos, mas sim uma relação entre atores (indivíduos, grupos) que acusam outros atores de estarem consciente ou inconscientemente quebrando, com seu comportamento, limites e valores de determinada situação sociocultural” (VELHO, 2003, p. 23). Contrariamente a uma sociedade do consenso "com ocasionais 'inadaptados"' (IBIDEM, p. 25, aspas do

\footnotetext{
${ }^{247}$ O interacionismo simbólico produziu as melhores análises da conduta desviante.

${ }^{248}$ Dentre estes é possível citar, por exemplo, os filiados à corrente da antipsiquiatria: Szasz, Laing, Cooper. Apenas para citar alguns.

${ }^{249}$ Esta seria "condição do ambiente social, não de indivíduos particulares" (MERTON, 1967, apud VELHO, 2003), diferentemente da anomia, relativa ao indivíduo. Segundo Velho (2003, p. 15), apesar de muito utilizado no estudo do comportamento desviante, o conceito de anomie, não foi adotado integralmente pelos estudiosos que dele fizeram uso. Exemplo disso é o caso de Merton, que faz uma revisão do conceito distinguindo-o de anomia. Também é possível notar uma modificação no uso deste conceito na medida em que alguns autores não veem no comportamento desviante apenas um sintoma de doença na sociedade, ele pode ser encarado também, para além de uma ameaça à existência da sociedade, como a "redenção" desta.
} 
autor), existem facções em conflito que se apresentam no confronto entre acusadores e acusados. A perspectiva de Becker em relação ao comportamento desviante não é aquela de uma "inadaptação cultural", ao contrário, é a de uma problemática política e de identidade (VELHO, 2003, p. 24).

São diversas as possibilidades de abordar a questão normalidade/anormalidade. Não é a intenção aqui cerrar fileiras contra esta ou aquela perspectiva. Trata-se apenas de apresentá-las, e ao mesmo tempo, alertar para o devido cuidado no seu manuseio, dando liberdade para que o leitor tire suas próprias conclusões. Tem-se clareza aqui quanto ao fato de a noção de desviante vir "carregada de conotações problemáticas" (IBIDEM, p. 17) como aquela, apontada por Becker (2008) e enfatizada por Velho (2003), relativa à "existência de um comportamento 'médio' ou 'ideal' que expressaria uma harmonia com as exigências do funcionamento do sistema social" (IBIDEM, aspas do autor). Também é dada a advertência para o perigo de se tratar o fenômeno em nível da individualidade, de "inadaptado" que, a despeito de um sistema social coercitivo, contraria os padrões existentes.

Desse modo, pode-se perceber que a noção de desviante carrega problemas na medida em que oscila "entre um psicologismo e um sociologismo" (VELHO, 2003, p. 17, destaque do autor). Isso resulta na tentativa de enquadrar o comportamento dos sujeitos em duas modalidades estanques, onde "ou se cria uma individualidade 'pura', uma 'essência' defrontando-se com o meio ambiente exterior [...], ou então um fato social 'puro', também todo-poderoso, que paira sobre as pessoas". (IBIDEM, p. 19, aspas do autor). Semelhante divisão indivíduo/sociedade, tão cara às Ciências Sociais, faz com que se perca de vista o "inter-relacionamento complexo e permanente" (IBIDEM) de algo que não está apartado. Nesse mesmo sentido, o uso de conceitos como o de "desviante" e "inadaptado" impossibilita trabalhar com uma visão dinâmica da vida sociocultural. É preocupado com essas questões que Velho (2003) previne a todos ao procurar "chamar a atenção para um grande hiato existente entre estudos 'individuais', 'psicologizantes' e grandes teorias sobre a natureza da sociedade, ou seja, o abismo entre a Psicologia, Psiquiatria etc e as Ciências Sociais como um todo" (IBIDEM, p. 23, aspas do autor). Acredita-se neste estudo, assim como o autor, ser imprescindível estar-se empenhado contra uma postura acrítica frente a essas questões. 
Os familiares, as autoridades religiosas, os profissionais de saúde são os que definem o que é socialmente aceitável e o que está passando dos limites, ou seja, a família, a Igreja, a psiquiatria são as instituições por meio das quais se elabora o diagnóstico dos pacientes. O patológico pode ser medido tanto em relação ao que se considera uma atitude religiosa saudável, como em relação às outras regras sociais em geral. O confronto entre acusadores e acusados do qual fala Becker (2008) - no que diz respeito à questão do sujeito rotulado desviante - deve ser cotejado aqui no que tange às decisões dos familiares, das autoridades religiosas em relação ao suposto transgressor. Nesse caso também, é possível perceber - tanto a partir de autores que trabalham com a temática (Cooper, Laing, Szasz) como mediante a perspectiva bourdieusiana - a conexão de tais decisões com o "confronto entre indivíduos que ocupam posições estruturalmente desiguais" (VELHO, 2003, p. 25). Assim, por exemplo, segundo Cooper (1989, p. 17, aspas do autor):

Esquizofrenia é uma situação de crise microssocial ${ }^{250}$, na qual os atos e a experiência de determinada pessoa são invalidados por outras, em virtude de certas razões inteligíveis, culturais e microculturais (geralmente familiais), a tal ponto que essa pessoa é eleita e identificada como sendo 'mentalmente doente' de certa maneira e, a seguir, é confirmada (por processos específicos, mas altamente arbitrários de rotulação) na identidade de 'paciente esquizofrênico’ pelos agentes médicos ou quase-médicos.

A medição dos níveis de normalidade acontece a partir de parâmetros que podem ser estabelecidos injustamente e que, a despeito disso, facilmente são acatados pelos profissionais que (por comodidade ou por necessidade) parecem, na verdade, buscar um reforço para o diagnóstico apoiando-se em falsas certezas: "A grande questão para a gente tentar errar menos nesses pontos é nunca ficar sozinho na avaliação" (M24). Recorre-se, portanto, à família, ao grupo religioso numa tentativa de solidificar um parecer sobre o paciente. Assim, as expressões "está exagerado", "aceitável para a família", "está um pouco demais", "não está adequado", "não é compartilhado", "não está dentro do contexto”, "passou dos limites", "está completamente desproporcional" ilustram este tipo de perspectiva ${ }^{251}$.

\footnotetext{
${ }^{250}$ Segundo o autor, "o termo microssocial se refere a um grupo finito de pessoas em interação face a face - pessoas que veem e são vistas, uma pela outra" (COOPER, 1989, p. 17).

${ }^{251} \mathrm{Na}$ concepção dos seguintes depoentes: M2, M6, M8, M9, M13, M16, M21, M26, E10.
} 
Já tive casos de, por exemplo, a pessoa que é evangélica e começa a entrar a fundo na religião, o que a gente chama de fanatismo e a família, sendo evangélica, falar: "Doutor, está demais. Está exagerado. Partindo da concepção que a família tem. Aí eu entendo um pouco da cultura do que é aceitável para aquela família, do que é saudável para aquela família e a família acaba me ajudando a entender o que está sendo saudável para o paciente. (M15).

Às vezes, os próprios [religiosos da comunidade] falam para a família trazer ou até trazem pra fazer uma avaliação psiquiátrica para ver se não tem alguma coisa a mais, então às vezes as próprias pessoas que estão naquele meio percebem que está um pouquinho demais, então eu acho que isso é legal, você tentar ver se dentro do contexto aquilo está adequado ou está saindo muito, se está causando prejuízo, prejuízo às vezes na própria igreja, na própria comunidade religiosa. (M3).

Dá para perceber quando é uma coisa que foge muito à regra. $E$ quando não é compartilhado pelas pessoas que convivem com o paciente. Essa é uma coisa que a gente sempre deve levar em consideração. Porque muitas vezes, quando é uma determinada manifestação cultural, é compartilhada pelo grupo de convívio da pessoa, pelos familiares, mas quando as próprias pessoas percebem que passou do limite [...]. (M14).

Sinceramente acho que pode [confundir o que é cultural e o que é sintoma], mas para eu não escorregar eu sempre pego outras pessoas que estão no meio da pessoa e pergunto. Muitos dos pacientes que a gente pega são encaminhados dos centros espíritas que as próprias pessoas que convivem e os religiosos acham estranho e encaminham para cá. (M24).

Ao mesmo tempo, há aqueles que procuram ter uma perspectiva mais moderada do que é "anormal" no paciente. Esse ponto de vista procura ater-se não ao conteúdo do que se fala, mas a forma como se fala, como se comporta. Nem sempre o que se fala sobre algo pode dar pistas sobre a doença - "Não depende só do que se fala. Mas de como se fala" (M16). Apesar de diferente e um pouco mais maleável, essa postura também está presa ao feedback do outro que não o paciente (a família, a igreja, etc): "[...] É o que falei: uma coisa é você ver e ouvir, outra coisa é o indivíduo ser diferente das pessoas que estão ao seu redor, que estão convivendo com ela" (M24). Segundo o depoente, uma coisa importante em psiquiatria é o fato de que não é exatamente o que o paciente relata que vai proporcionar o seu diagnóstico. É necessário, portanto, não se ater ao conteúdo do que é descrito pelo paciente: "Não é porque envolve um conteúdo religioso, porque às vezes os conteúdos, em psiquiatria, são os menos importantes" (M24). paciente pode falar de um conteúdo religioso bem como de qualquer outro tipo de 
conteúdo (por exemplo, político). Portanto, em oposição, o importante é estar atento à forma como a pessoa apresenta-se, à maneira como ela estrutura esse conteúdo na vida dela: "As pessoas podem ser religiosas/fanáticas e não ter nenhum problema na vida" (M24). À forma está associado um não enquadramento nas normas sociais, um conjunto de atitudes não compartilhadas com outras pessoas. Disso pode resultar o sofrimento e, desse modo, pode-se constatar que a doença esteja instalada na vida do sujeito.

Verdade seja dita, na psiquiatria - mais do que em outras áreas médicas que com mais segurança definem o saudável e o não saudável -, as fronteiras entre o normal e o patológico aparecem como mais difíceis de demarcar. A visibilidade dos fenômenos mentais é de outra ordem e não possuem uma clareza como ocorre em outros setores. Assim não é de se espantar o desabafo de E2 ao afirmar: "Eu fico pensando... vai que é espiritual, que o homem está vendo, que ele está ouvindo tudo aquilo. A ciência diz que é uma coisa da cabeça, mas vai que é um lado espiritual?" (E2). Não é fácil diferenciar os dois estados, admite M15. Mesmo porque "nada em psiquiatria é fácil, nem as categorizações nem o contato com o paciente" (M15). É um grande desafio lançado a esses profissionais, os quais têm de lidar a todo o tempo com limites tão tênues como os que existem entre o normal e o patológico (M15).

Se constatar que o paciente não está tendo um delírio religioso, é possível dar a ele a possibilidade de trabalhar suas questões religiosas: "Eu acho que o primeiro passo é a avaliação para saber se é uma doença. Depois, se você descartar a possibilidade, aí você pode até cogitar a ideia, trazer um apoio [religioso]" (M6). Assim, acredita-se que o primeiro passo seja "cuidar da área delirante" (M23) e evitar que as pessoas embaralhem questão psiquiátrica com questão espiritual, o que é comum, principalmente, entre os espíritas: "Porque muita gente confunde, fala: 'Meu problema não é médico, é espiritual, eu sou médium'; mas se for mediunidade é completamente encaroçada" (M23). Por isso, é importante tomar o devido cuidado no momento de avaliar, ser perspicaz e perceber, por exemplo, "que a medicação do paciente já deveria estar fazendo efeito, o que resta pode ser mesmo um discurso de cunho cultural, um fator ambiental." (E9.) 
A presença da religião (especificamente de um atendimento religioso) é delicada, pois ela suscita questões como as de culpa e perdão (M10) $)^{252}$ que podem prejudicar os pacientes, principalmente os psiquiátricos para os quais a religião seria "uma forma de pressão a mais" (M10). E não esbarra nisso somente, a religião pode ser prejudicial nos casos em que o paciente "está bem psicótico e o delírio dele tem um conteúdo religioso muito forte" (M11) a ponto, por exemplo, de falar que nas visões que teve foi orientado a não tomar a medicação. Além do que, o delírio pode se agravar (M12) com um contato religioso. Desse modo, o serviço religioso pode ser desairoso e visto com ressalvas no caso da psiquiatria; ao contrário é até recomendado para outras áreas da medicina, "para pacientes em estado terminal, os quais precisam muito desse tipo de suporte" (M12).

À religião, alguns psiquiatras creditam os seguintes adjetivos: "saudável" e "não saudável". A partir dessa classificação, eles a caracterizam respectivamente, de um lado, como sustentação para o paciente e, de outro lado, como sintoma da doença. Assim, ao mesmo tempo em que é considerada causa de delírios, a ela é também designado o papel de disciplinadora, doadora de regras, fortalecedora. Ou seja, um papel ambíguo de redentora e algoz. Os casos mais exemplares da religião enquanto doadora de regras são os de dependência química. Nessas situações, particularmente, a religiosidade e as normas a ela relacionadas conseguem uma tranformação no sentido da abstinência e da disciplina (M9).

Se a religião é classificada valorativamente como "saudável" ou "não saudável", ela também é categorizada em termos de utilidade. A religiosidade do paciente pode ser uma informação importante no sentido de que talvez ela possa ser usada para ajudar (M3) e aí ela pode ser trazida à tona. O auxílio, entretanto, pode ocorrer em duas direções ${ }^{253}$ : 1) para diferenciar o estado da patologia ${ }^{254}$ 2) para ajudar a explicar a doença (tanto por parte dos religiosos quanto dos pacientes). Nesse último caso, a religião pode ser vista, mesmo dentro do quadro do delírio, como uma forma de elaboração, de melhor entendimento do quadro patológico, ajudando o paciente a dar sentido, a explicar a doença. Ela pode ser um recurso

\footnotetext{
${ }^{252}$ M10 é psiquiatra mono-posicionado.

${ }^{253}$ Fora desses objetivos existe um ceticismo, um estranhamento mediante tal questão.

254 M15 afirma que as discussões quanto ao tema "religião" aparecem nos casos de saber se é questão cultural ou delírio, fora desses casos o depoente diz nunca ter participado de nenhuma discussão.
} 
para compreender tanto o surgimento da doença como o seu fim. Já as significações concedidas à doença, no âmbito da simbologia religiosa (como já visto), fazem referência a milagres, ao demônio (conhecido também pelo nome de "inimigo") enquanto propiciador da doença, a Deus enquanto guiador da mão do médico.

A paciente reelaborou, mas mantém ainda algumas coisas que não dá mais pra saber se é psicose ou não porque pode ser crença e crença é crença. "Deus entrou em mim e aí..." ela ficou psicótica, mas se ela acredita nisso, se é a maneira como ela elaborou isso... porque a mente estava lá toda fragmentada e melhorou e pousou, do jeito que pousa é como fica. É como ela explica a vivência que ela teve. Ela precisa explicar se não ela fica louca. Nesse momento, a questão é: ela está ainda delirante, a gente aumenta o remédio? Não aumenta o remédio? Ou é crença dela? (M24).

$\mathrm{Na}$ esteira do modelo de um discurso competente e superespecializado que não abre possibilidade para enxergar "o sujeito humano como uma realidade plural e imprevisível” (COSTA, 2007, p. 34), desaparecem, por exemplo, os modelos teóricos que poderiam "solidarizar-se com aqueles que, por uma ou outra razão, são estigmatizados como minoria pela cultura hegemônica, e impedidos, em maior ou menor grau, de exprimirem livremente o que pensam ou sentem" (IBIDEM, p. 35). Nenhum dos profissionais de saúde aqui analisados - sejam eles bi-posicionados, mono-posicionados ou neutros - escapa de um modelo a muito arraigado, o qual gera o habitus para sentir a necessidade de tal prática. Todos eles, mesmo os que contestam o modelo vigente, acabam por corresponder a tais exigências, visto que como afirma Bourdieu, agentes nativos têm o "jogo na pele”. Ou seja, o biológico é um modelo claramente hegemônico no sentido de exercer uma influência, penetrar no ambiente psiquiátrico. Entretanto, isso não significa que ele seja dominante (no sentido de relação de poder, de imposição) entre os profissionais; ao contrário, como se pode notar, há os que não se identificam com ele no seu formato duro (que é de exclusão e não maleabilidade aos fatores culturais). 


\subsubsection{Sintoma da doença versus Reestruturação da vida, dois sintagmas $^{255}$}

\section{- "Negativamente ou positivamente" (tanto para o mal como para o bem)}

O posicionamento ambíguo de alguns psiquiatras pode ser visualizado por intermédio da função também ambígua por eles atribuída à religião. A influência da religião na vida do paciente pode acontecer em dois sentidos sempre muito bem lembrados pelos psiquiatras: tanto pode interferir negativamente quanto positivamente. No primeiro caso, quando ela aparece como sintoma da doença (trazendo consigo questões como culpa e pecado; fazendo com que o paciente abandone o tratamento ou não tome os remédios) e não como necessidade religiosa de fato. No segundo caso, quando ela proporciona uma sustentação ao paciente, ajudando-o a superar de forma menos dolorosa possível a doença. Há os dois lados: a religião pode ajudar, mas ela pode também atrapalhar (M16, M13, E2).

Eu acho que tem pessoas que foram criadas nisso e se apoiam nisso. Que contam com a religião como um suporte para as agruras da vida. Nesse sentido eu acho que é positivo, sim, quando a pessoa consegue equacionar isso é positivo. Eu acho negativo quando isso impede que a pessoa olhe para si mesma e se responsabilize pelos atos da vida dela. Quando a pessoa delega todos os fatos da vida dela a uma possível influência espiritual, qualquer coisa assim, simplesmente. $(\mathrm{M} 15)^{256}$.

Acho uma coisa positiva no geral. Acho que ajuda, que traz apoio, determinação e ao mesmo tempo eu tive algumas experiências que são muito negativas. Como tudo, tem os dois lados. Eu já tive pacientes que estavam totalmente psicóticos e que foram em determinadas igrejas que não houve dúvida em dizer: "Olha, você esta possuído pelo demônio". (M20).

Há religiões que impedem o tratamento psiquiátrico, têm atitudes "contraproducentes para o tratamento" (M2). São opositoras, por exemplo, como é o caso de alguns grupos serem "contra o tratamento porque acham que o paciente

${ }^{255}$ Psiquiatras ( 2 mono-posicionados, 4 bi-posicionados, 12 neutros) e enfermeiros ( 1 neutro) foram arrolados para discutir a problemática.

${ }^{256}$ M15 é psiquiatra mono-posicionado. 
tem espírito obsessor, que não é o psiquiatra que vai curar" (M2). Elas podem "interferir no mau sentido" na medida em que ficam "alimentando a mania". Os médicos tentam "tirar o excesso de estimulação da mente [...] baixar a bola", enquanto que a religião, algumas vezes colabora para o contrário. Esse lado é encarado como sendo nocivo (M4). A interferência negativa pode ocorrer mediante a "crença de que Deus vai curar, então não precisa de remédio". Essas seriam consideradas "crenças incompatíveis" 257 com a medicina. Há o caso clássico dos Testemunhas de Jeová, entre os quais é comum a crença de que não pode receber sangue, com esse grupo há "problemas sobre alguns procedimentos" (M10). Nesse sentido, grande parte dos psiquiatras vê a religião como "uma forma fechada de se pensar" (M24).

É uma questão controversa entre os profissionais, os quais apontam que "em certos momentos o apego exagerado a certas religiões atrapalha a saúde do próprio paciente" (M17). Tudo vai depender de como a religião aparece na vida do sujeito: se surge como uma necessidade ou se desponta como uma forma de "esconder/mitigar sintomas" (M20). Neste último caso, irá atrapalhar muito o tratamento (M20), na medida em que é utilizada de forma patológica (um exemplo é o caso de uma paciente judia que tem anorexia nervosa e apoia-se na religião para não comer, relatado por M22). Dessa maneira, acredita-se que, assim como pode ajudar, a religião pode também mascarar uma compreensão de si mesmo e tirar a responsabilidade sobre a própria vida (M15).

São diversas as características de cada religião, é necessário que haja acuidade por parte do profissional para captar essas peculiaridades (exemplificadas mediante os Testemunhas de Jeová e a questão da transfusão de sangue). Por isso, informações básicas sobre as religiões podem ser de grande valia para o psiquiatra enquanto profissional que lida com a vida humana, acredita M24; bem como é imprescindível ter conhecimento (caso haja um serviço religioso) quanto ao tipo de abordagem oferecida e obter informação se a pessoa que o faz é coerente, se o ministro religioso "não está mais psicótico do que o paciente" (M7). Acredita-se, assim, que a religião pode e deve ser utilizada como uma ferramenta para compreender melhor o paciente (M4) - "[...] A busca de uma informação, de uma compreensão da religiosidade do paciente isso é desejável na avaliação" (M26).

${ }^{257}$ Em contraposição ao que se considera, como já visto anteriormente, uma religião saudável. 
Desse modo, a formação do médico na graduação e nos demais cursos deveria conferir espaço para disciplinas que deem maior atenção para essa questão. Principalmente ao se considerar que a população brasileira é, em grande parte, religiosa.

O conhecimento das crenças dos pacientes pode auxiliar nas conclusões, nos diagnósticos, fornecer um parâmetro de avaliação, já que muitos deles são diagnosticados como tendo delírios religiosos. O caso, por exemplo, de uma "religião menos comum" (M9) que sai "um pouco da média da cultura brasileira" (M9) pode assim chamar a atenção do profissional o qual procurará conhecê-la melhor. É importante considerar, ainda, o fato de que o profissional pode carregar preconceitos em relação a determinadas crenças, o que poderá influenciar em relação ao diagnóstico. Se o profissional não possui uma "vivência interna" em relação à religiososidade, segundo $M 21$, muito provavelmente ele não compreenderá atitudes religiosas do paciente; por exemplo, Ihe será incompreensível "porque um crente vai num culto e entra num transe cultural, religioso" (M21). Isso é relativamente complicado, pois na medida em que não há entendimento pode haver um préjulgamento nocivo: "Quem falou que quando a gente fala que o paciente está delirando, a gente não está emitindo um juízo de valor?" (M15). Todo o cuidado é pouco, pois as fronteiras não são rígidas e por conta disso muita cautela é necessária "para que isso não vire uma questão estritamente pessoal" $(\mathrm{M} 15)^{258}$.

Para ter o conhecimento dos diversos tipos de crenças e para abordá-las junto ao paciente, se necessário, o profissional de saúde deveria estar informado. Como já comentado em outra parte da tese, há uma demanda por aprendizagem sobre esses aspectos, no entanto, não existe um projeto sério nos hospitais nesse sentido $^{259}$. Na anamnese do paciente, a questão religiosa tem grandes chances de aparecer e, neste momento, certamente ela deve ser abordada, destrinchada. Para que isso aconteça com sucesso, o psiquiatra deve estar bem preparado, munido de informações básicas a respeito deste objeto. Por vezes, não considerar a religião do paciente pode conduzir a um fracasso no tratamento. A compreensão da religião

\footnotetext{
${ }^{258} \mathrm{M} 15$, apesar de ser mono-posicionado (contra a fixação de um atendimento religioso no hospital), é autocrítico em relação à postura médica.

259 Aí surge novamente a questão de que, ao contrário do que acontece na maior parte das universidades norte-americanas, que oferecem cursos na graduação, no Brasil, estima-se que haja por volta de oito faculdades de medicina com cursos, disciplinas que tratem da questão, no total das faculdades. (M13).
} 
como estratégia ${ }^{260}$ para o tratamento é algo levado em consideração por alguns psiquiatras: "Se o médico não entender, não souber abordar a doença sob a perspectiva do paciente e essa perspectiva pode ser religiosa, ele seguramente vai fracassar no tratamento" (M16).

Mesmo não sendo função do médico conversar sobre questões religiosas com o paciente, na perspectiva de alguns informantes, não se deve considerar como irrisória a função da religião enquanto "uma ferramenta terapêutica" (M10) ${ }^{261}$. Mesmo aquelas religiões que são consideradas como oponentes ao trabalho do psiquiatra, que dificultam a sua atividade profissional devem ser levadas em consideração "até para poder perceber e entender uma melhor forma de lidar ou de esclarecer essas pessoas, de saber como lidar" (M14). Ou seja, dependendo do impacto que tem na vida do paciente, deve ser visto como mais um dado relevante (M15).

A vulnerabilidade do paciente no momento da internação leva a crer que é perigoso incentivar uma religiosidade/espiritualidade nessa situação. Se ela existia antes da internação, se já era importante para o paciente (pensando em como ela poderia ser importante para o paciente lidar com a doença), talvez até possa ser uma aliada no tratamento; caso contrário, é necessário avaliar, pois "qualquer coisa que se falar para ele tem uma influência muito grande no psiquismo" (M4). Por isso mesmo, afirmar que pacientes que possuem alguma religião melhoram com mais rapidez do que os que não possuem ${ }^{262}$ é arriscado, pois trata-se de um "elo de pensamento que até atrapalha o tratamento. É uma dificuldade muito grande para ajudar a pessoa a encontrar o eixo, aceitar. Na psiquiatria acho que isso é um pouquinho meio fora do restante da medicina". (M19)

\footnotetext{
260 "Por exemplo, o paciente que tentou o suicídio, eu preciso saber: 'Eu não quero mais viver, eu não acredito em mais nada'. Você, dentro da história, pergunta: 'Qual é a sua religião?' Dentro da religião esse é um ponto de apoio importante. 'Você é católico?' 'Sou católico' 'Cadê a sua fé? No que você acredita?'. Ou outros dizem: ‘Eu penso em me matar, mas eu não me matei ainda'. 'Por quê?' 'Porque dentro da religião católica o suicídio é [sic] uma conotação negativa'”. (M16).

${ }^{261}$ M10 acha que se o médico e o paciente compartilham a mesma fé e podem ter o vínculo mais fortalecido por causa disso, o médico pode conversar com o paciente sobre questões relacionadas à fé/religião: "Eu vejo isso mais entre os casos de pacientes judeus. Porque eles têm uma identificação maior, médico judeu com paciente judeu. Eu acho que é um vínculo a mais que se forma e fortalece a confiança, as decisões tomadas em conjunto". (M10).

${ }^{262}$ Questão aplicada aos psiquiatras e enfermeiros para captar como eles percebiam a relação religião/saúde. A questão foi realizada da seguinte forma: "O que você acha da afirmação de que pacientes que possuem alguma religião melhoram mais rapidamente do que aqueles que não possuem?".
} 
Os que concordam que as pessoas que têm crenças religiosas, são religiosas praticantes tendem a ter melhor qualidade de vida ${ }^{263}$ e saúde do que aquelas que não têm ${ }^{264}$ alertam quanto ao fato de que para pensar essa questão seria necessário saber quanto tempo a pessoa pratica a religião (M8) ou se ela começou a frequentar quando ficou doente. Reflexão importante para que não se faça julgamentos equivocados, pois ao tentar estabelecer uma relação como esta existe grande possibilidade de se encontrar um número elevado com problemas psiquiátricos, visto que normalmente essas pessoas procuram a religião porque "tinham problemas e não o contrário" (M8). Assim, no caso de "pessoas que previamente não tenham antecedentes psiquiátricos, aquelas que são praticantes eu tenho impressão que a religião ajuda" (M8). Alguns acreditam: o correto não é simplesmente afirmar que o paciente que tem religião melhora comparado ao que não tem. A experiência de alguns profissionais não indica exatamente isso, mas sim, a relação "entre as diversas religiões e a maneira como as pessoas compreendem a doença e tomam o rumo da sua vida" (M15).

Considera-se também a relação que há entre ter ou não ter religião e o contexto social do indivíduo. Nesse caso, aparece a religião como uma forma de salvação das agruras da vida, perspectiva conhecida nas ciências sociais da religião. O apego à questão religiosa é cotejado em relação à precariedade em que vivem certas pessoas, inseridas que estão no contexto de um país sem recursos em que "são muito sofridas" (M16). Assim, sob esse ponto de vista, a religião desponta graças ao apoio emocional nos momentos difíceis, por "dar um suporte aonde o serviço de saúde é falho" (M18). Essa pode ser uma das maneiras de se pensar a questão. Segundo Concone (2003, p. 47-48), na ânsia por explicações para a questão da busca de solução para a doença e o sofrimento fora do espaço médico,

\footnotetext{
${ }^{263}$ Parece não haver consenso na literatura em relação ao conceito de qualidade de vida, a qual é considerada diferente do conceito de padrão de vida. Este, segundo PANZINI et al. (2007), estaria relacionado a questões socioeconômicas, demográficas, de cuidados básicos de saúde. Já a qualidade de vida "baseia-se em parâmetros que se referem à percepção subjetiva dos aspectos importantes da vida de uma pessoa, os quais podem ou não coincidir com indicadores de padrão de vida [...] O Grupo de Avaliação da Qualidade de Vida da Divisão de Saúde Mental da OMS (Grupo WHOQOL) propôs que essas percepções se originam na cultura à qual a pessoa pertence. Por isso, a questão cultural é fundamental na Qualidade de Vida (QV), já que diferentes culturas tendem a priorizar diferentes aspectos [...]".

${ }^{264}$ Questão aplicada aos psiquiatras e enfermeiros para captar como eles percebiam a relação religião/saúde. A questão foi realizada da seguinte forma: "O que você acha da afirmação - que se baseia em pesquisas - segundo a qual, na maioria dos casos, as pessoas que têm crenças religiosas, que são religiosos praticantes, tendem a ter melhor qualidade de vida e saúde que as que não as têm?".
} 
os motivos podem ser "arrolados com maior ou menor sofisticação". Uma perspectiva mais crítica seria justamente a que aponta - associada à questão da pobreza de boa parte da população - para os problemas existentes no sistema de atendimento à saúde, "no qual a universalidade seria apenas nominal" (CONCONE, 2003, p. 47-48). Claro está que as conclusões não podem encerrar-se apenas em tal perspectiva, provavelmente existem outras questões além dessas que circundam a problemática do apelo às religiões.

Sob outros aspectos que não o econômico, a religião pode ser uma aliada, ter um efeito positivo (e que fique claro: desde que solicitado ${ }^{265}$ ), podendo ajudar o paciente deprimido "que tem fé e acredita na religião como uma fonte de apoio/cura" (M2), "reintegrando/reinserindo esse sujeito nos valores dele" (M4). Ou seja, por ser um mecanismo "para o indivíduo poder se estruturar, vencer uma angústia existencial, [...] se segurar um pouco" (M24), os conceitos da religião podem, portanto, ser úteis.

No entanto, os psiquiatras acreditam que, assim como existe o contexto social/cultural, existe o contexto da doença e manifestações religiosas consideradas exageradas são vistas como fazendo parte deste último contexto: "Então, a gente acaba tratando isso como uma manifestação da própria doença naquele momento" (M8). Ou seja, a abordagem científica do comportamento religioso não é deixada de lado. Onde a religião aponta um caso de possessão demoníaca, a psiquiatria demonstra, por meio de recursos, de técnicas científicas, tratar-se de crise epiléptica: "Eu tenho uma paciente hoje que teve uma possessão demoníaca na minha consulta, mas, incrivelmente, essa possessão demoníaca dela é uma crise epiléptica. Foi feito um exame e mostrou-se no cérebro: ela teve uma crise epiléptica e, durante essa crise, parece que está tendo uma possessão demoníaca. Que entra bem como um quadro de psicose. E melhora com remédios" (M24). A psiquiatria e seus profissionais, vez ou outra, são defrontados com situações em que explicações religiosas antecipam-se ao "verdadeiro" diagnóstico.

\footnotetext{
${ }^{265}$ Tanto o atendimento religioso como a conversa sobre religião com algum profissional deve partir, segundo a maior parte dos profissionais de saúde mental (médicos e enfermeiros), de demanda do paciente.
} 


\subsubsection{Religião enquanto sintoma da doença ${ }^{266}$ : sintagma 1}

Como apontado anteriormente, a religião como sintoma da doença é um dos Leitmotiv do discurso psiquiátrico. Ele é utilizado para alertar sobre o lado negativo da religião e para justificar o temor de se falar da questão num ambiente médico ${ }^{267}$ É praticamente um consenso que, muitas vezes, a religião aparece como sintoma da doença no chamado "delírio religioso". Nesse caso, o procedimento deve ser o cuidado para não reforçá-lo (M3, M8): "Tem pacientes psiquiátricos que às vezes essas questões ligadas à religião fazem parte do discurso do paciente, às vezes o paciente tem uma ideia delirante/fantástica que envolve temas religiosos" (M8). Por isso, é necessário ser muito bem avaliado para captar até onde a questão é mesmo "religiosa ou até quando isso já está virando um problema para o paciente" (E7).

Eu penso o seguinte: se for só o lado religioso não vai melhorar com remédio. O remédio não vai melhorar. $\mathrm{E}$ muitas vezes só ajustando doses da medicação ela para de ter. Então, eu já considero que não é uma coisa mediúnica, nada disso. Na verdade era a doença que estava agindo. [...] Por exemplo: uma pessoa que tem transtorno obsessivo compulsivo que fica com a ideia que tá pecando o tempo inteiro, na verdade aquilo é uma obsessão e não tem nada a ver com pecado, com religião. Eu acho que primeiro você tem que descartar a causa clínica. [...] Eu tive paciente que estava no ambulatório que eu atendia ele ia muito/demais à igreja, aqui no hospital e ele era esquizofrênico e basicamente quase tudo que ele tinha de delírio era relacionado a coisas religiosas. Ele ficava achando que estava pecador. E a gente, em determinado momento, fez um gráfico de idas/frequência à igreja e frequência dos sintomas. Quanto mais ele ia para a igreja/culto, mais sintomas ele tinha. A partir do momento que ele reduzia ele ficava um tempo melhor. Ele ia à igreja era como se fortalecesse todas aquelas crenças delirantes que ele tinha. (M6).

Acho que é um tema que sempre vem. Nós acabamos de internar uma paciente ontem dizendo que é Maria Madalena. É uma questão que está sempre presente no conteúdo dos delírios dos pacientes psicóticos. [...] Tem população mais simples, que é evangélica, tem muito essa coisa do dom. O dom da oratória, da palavra, da cura. É muito comum. [...] Dentro da epilepsia tem psicoses... impressionante... religiosos com dom de línguas estrangeiras. (M16).

\footnotetext{
${ }^{266}$ Psiquiatras (3 bi-posicionados, 6 neutros) e enfermeiros ( 2 neutros) falam do seu ponto de vista.

${ }^{267} \mathrm{Na}$ concepção dos seguintes depoentes: M3, M6, M8, M16, M21, M23, M24, E5, E7.
} 
Especiosa essa ideia? Da mesma forma em que se acredita ser a religião, em certas ocasiões (não raras), sintoma da doença, há outra perspectiva que considera existir uma religião saudável. A reflexão sobre a medida do que é uma "religião saudável", vez ou outra vem à tona tanto na perspectiva religiosa quanto na perspectiva médico-psiquiátrica. Nessa última, acredita-se que "algumas maneiras de ser religioso podem ter um efeito benéfico ou prejudicial sobre a saúde" (LOTUFO-NETO, 1997, p. 33). Desse modo, o profissional do campo das psi deve procurar identificar "as formas de religião que podem conduzir a uma saúde mental madura e saudável e quais as que podem ser prejudiciais ou patológicas" (IBIDEM). Isso porque a religião pode tanto ser um benefício quanto um empecilho: "A religião pode ser um abrigo, um perigo, uma terapia, uma expressão ou uma supressão de doença mental" (IBIDEM).

Essa classificação maniqueísta e, portanto, valorativa aparece (quando vinda dos psiquiatras e enfermeiros) ${ }^{268}$ numa tentativa de selecionar um estilo de vida uniforme que dê conta de toda necessidade humana, determinando que o que é bom para um indivíduo, o será também para todos, fazendo lembrar aquele velho adágio conhecido: "O interesse coletivo supera o individual". Assim, é possível deparar-se com afirmações que se referem às possíveis "visões distorcidas do paciente", a uma "religião fanática" (M13), uma religião fora do eixo da normalidade: "Se for uma coisa moderada pode até ajudar. Se não for aquela da pessoa ficar muito bitolada [...] se for uma coisa sadia, dentro dos normais parâmetros" (E7). Normalmente irá se esbarrar numa "questão muito delicada que sai fora da população geral" (M19), no caso da psiquiatria, que é a de que seus pacientes, principalmente nos quadros denominados psicóticos, "tendem a ter ideias delirantes religiosas" (M19). E, nesses casos, se não se souber diferenciar "o que é patológico e o que é pensamento saudável religioso" (M19), poderá haver uma interferência no tratamento psiquiátrico (pensando em termos de uma atuação de religiosos junto a pacientes psiquiátricos).

Assim como em outros tempos, os psiquiatras da $\mathrm{LBHM}^{269}$ pediam que se "educasse o povo segundo os princípios de uma religião sadia", a católica no caso (COSTA, 2007, p. 105), hoje existem, ainda, aqueles que nomeiam certas religiões

\footnotetext{
${ }^{268}$ Esse tipo de discurso, quando vindo dos religiosos, está ligado à disputa religiosa relacionada a uma realidade de diversidade e conflito religioso.

${ }^{269}$ Liga Brasileira de Higiene Mental.
} 
como saudáveis. Essas são vistas como mais protetoras da doença mental; ao contrário, uma religião não saudável estimularia os delírios naqueles que os têm e incitaria os delírios naqueles que ainda não os têm ${ }^{270}$.

\subsubsection{Religião enquanto reestruturação da vida ${ }^{271}$ : sintagma 2}

O lado positivo de se valer do mundo religioso é referido em expressões como: "socialização", "estilo de vida”, "regras", “apoio”, “interação social”, “ajuda”, "lidar melhor com a doença e o sofrimento humano", "impedir o suicídio", "ter outra visão em relação à morte". É comum essa constatação, apesar de não ser nova tal descoberta, há muito tem se falado da importância que, normalmente, é atribuída à religião para a compreensão do sofrimento humano ou mesmo dos privilégios, como mostrou Weber, em relação à teodiceia dos favorecidos e desfavorecidos, e Bourdieu, em relação à justificação da posição ocupada (sociodiceia). Como já comentado no início deste trabalho, a religião - ao contrário da ciência - é doadora de sentido, mediante o apelo aos seus recursos o indivíduo consegue fazer a ponte entre o como e o porquê de sua enfermidade.

[O indivíduo] não pode, principalmente se o que o aflige é grave e doloroso, ater-se ao como do episódio mórbido, mas passa subrepticiamente, de um momento para outro, a um questionamento do porquê, ou seja, a uma busca, procurando nos materiais postos à sua disposição por sua cultura uma explicação quanto à origem última de sua doença: ele não cessa de buscar, até que a tenha encontrado, uma responsabilidade decisiva, quando não um responsável e até mesmo um culpado. Em suma, trata-se da questão do sentido (e principalmente do sentido metafísico). (LAPLANTINE, 2004, p. 235).

É possível averiguar esse tipo de comportamento ao longo dos tempos: seja por intermédio das religiões fortemente clericais, seja por meio das religiosidades anti-institucionais (místicas) ou ainda mediante a peculiaridade da realidade religiosa

\footnotetext{
${ }^{270}$ Isso na perspectiva dos psiquiatras. Já para os religiosos, como visto em outro momento, a religião não saudável é aquela que se encaminha na direção do fanatismo.

${ }^{271}$ Psiquiatras (2 mono-posicionados, 6 bi-posicionados, 14 neutros) e enfermeiros (1 bi-posicionado, 7 neutros) abordam a questão.
} 
brasileira, na qual há "[...] certa tradição popular em considerar as diferentes religiões como equivalentes funcionais no que se refere à concessão de proteção e quanto à orientação comportamental” (NEGRÃO, 2008, p. 130).

A religiosidade, na maior parte das vezes, impacta positivamente a saúde, afirmam categoricamente alguns psiquiatras bi-posicionados e psiquiatras neutros/ambíguos. Como os médicos têm obrigação de conhecer os fatores que influenciam a saúde - seja positivamente, seja negativamente -, eles precisam estar informados sobre os aspectos religiosos presentes na vida do paciente (M1), os quais podem estar relacionados à qualidade de vida ${ }^{272}$ : "Acho que a religião é um suporte importante na vida da pessoa, na qualidade de vida dela. Principalmente quando vêm os problemas" (M7). Segundo Peres et al. (2007), a maioria dos estudos tem demonstrado que índices de saúde (por exemplo, maior longevidade, qualidade de vida, menor ansiedade, depressão e suicídio) estão relacionados a envolvimento religioso e espiritualidade. Assim sendo, alguns profissionais não fazem tábula rasa dos benefícios da religião na saúde dos pacientes. Ainda que possa haver aspectos negativos $^{273}$ relacionados a determinada religião ou religiosidade, as crenças espirituais podem interferir, na maior parte das vezes, de forma positiva.

Entretanto, alerta-se quanto ao fato de que é difícil concluir qual a direção da causalidade: a religião ou a qualidade de vida. O paciente vai mais à igreja porque está bem de saúde ou está bem de saúde porque vai à igreja? Deve-se considerar, alertam alguns, que o paciente que é religioso já o era antes de ficar doente (M24), além do que, são tantos os fatores que podem tanto ajudar na melhora quanto o contrário que é arriscado fazer qualquer tipo de afirmação (M24).

Mas aí tem uma coisa também que a gente discute. Por exemplo: você pega, de um grupo de religiosos, pessoas que estão menos

\footnotetext{
${ }^{272}$ Podem estar relacionados quer dizer que não se pode afirmar categoricamente que estejam. É o que acredita E4: "Eu acho que é uma coisa muito subjetiva. Não dá pra gente afirmar que qualidade de vida é religião ou não ter religião. Acho que é fácil: você pega um grupo de pessoas católicas praticantes, aqueles jovens na igreja cantando, praticando alguma atividade na igreja, quando eles olham na televisão que tem um rapaz que foi para o baile funk e levou um tiro, eles falam: 'Se ele tivesse na igreja teria melhor qualidade de vida e não tinha levado um tiro'. Mas eu acho que é muito subjetivo. O contraponto disso é o cara que está no baile achar que eles estão perdendo tempo. Acho que a qualidade vida é muito subjetiva". (E4).

${ }^{273}$ Nesse sentido, afirma M24 quanto a pessoas que são religiosas terem melhor qualidade de vida: "Eu já conheci muitos religiosos praticantes que têm muitos problemas na própria vida em decorrência da religião. Conflitos com a religião que ele não segura. As pessoas... principalmente no ambulatório de sexualidade que a gente atende. Que a religião, principalmente a católica, é bastante contra qualquer forma de sexualidade que não seja a matrimonial".
} 
doentes. Por outro lado, as pessoas que vão à igreja elas vão porque estão com saúde, quem não tem saúde fica em casa, não consegue sair nem de casa. Então, a gente não sabe se isso é causa ou consequência. É muito difícil definir a direção da causalidade. Quem causa o quê? Eu vou muito à igreja porque tenho saúde, estou disposto, posso andar, não estou deprimido para ficar deitado na cama. Então, eu vou mais à igreja. Ou não? Eu tenho mais saúde porque eu vou mais à igreja? (M6).

Aí fica naquela coisa do mecanismo causal: será que a pessoa é religiosa e, por isso, ela tem melhor qualidade de vida ou será que ele tem melhor qualidade de vida e aí... não dá pra saber. Na nossa cultura parece fazer sentido isso. Essa religião seja lá qual for o mecanismo causal. As religiões na nossa cultura têm uma relação com qualidade vida importante. Seja a qualidade de vida levando a uma religião, seja a religião levando a uma qualidade de vida. Faz sentido na nossa cultura. (M18).

[Resposta à afirmação de que pacientes que possuem alguma religião melhoram mais rapidamente do que aqueles que não possuem] Geralmente quem é religioso já era religioso. Não dá pra você comparar essa pessoa com uma outra pessoa porque essa pessoa é única. É difícil você arranjar um controle para esse indivíduo [...] É difícil porque é tudo muito multi-fatorial, principalmente em psiquiatria. Você vai pegar um grupo de religiosos, desse pega os deprimidos e um grupo de não religiosos, desses pega os deprimidos. Trata e vê qual melhora. Pode ser, mas é tanto fator que causa depressão que não dá pra saber se não tem outros fatores aí conflitando. (M24).

Diversos estudos têm sido realizados nessa direção, correlacionando maior envolvimento religioso e menor Score de depressão (M1, M2) bem como menores índices de suicídios, menor uso de álcool/drogas e melhor qualidade de vida ${ }^{274}$. Ideias consideradas preconceituosas - que foram sendo transmitidas sem muito critério e que quando testadas na população "não se sustentam" (M1) -, de que o religioso é mais deprimido, despreza o corpo, são rechaçadas e aponta-se o contrário: "[...] espiritualidade é um fator benéfico na grande maioria das vezes para a recuperação do paciente" (M13).

Na perspectiva de alguns psiquiatras é necessário, pelo menos, sondar se a religião é importante na vida dos pacientes (M1). A religião pode trazer benefícios não só do ponto de vista espiritual, mas também do ponto de vista social (M4): de interação social (M4, E9), de fazer parte de um grupo social (M10, M14). A organização moral rígida, a disciplina - "Um código de comportamento, de regras e

\footnotetext{
${ }^{274} \mathrm{Em}$ relação à saúde de um modo geral, o dado mais consistente diz respeito à mortalidade, no sentido de que, em média, os mais religiosos têm maior sobrevida do que os não-religiosos (M1).
} 
de valores bastante restritivo, organizado" (M14) - vinculadas à religião são apontadas como auxiliares no restabelecimento do paciente, uma vez que favorecem uma mudança no estilo de vida que ajuda principalmente dependentes de álcool e drogas (M4, M6, M9, M14) e impedem, até mesmo, que os não usuários entrem no caminho das drogas (E2, E9). Segundo sugere Sanchez e Nappo (2007), "a religiosidade e a espiritualidade vêm sendo claramente identificadas como fatores protetores ao consumo de drogas em diversos níveis". Na verdade, existe algo por trás desse poder da religião que é relativo ao fato de que "os seus mecanismos de ação são muito mais psicológicos e sociais do que uma questão transcendental" (M14). Entretanto, independente de transcendental ou de social/psicológica, acredita-se que a religião "é uma força que a gente não pode desprezar" (M14).

Pessoas com grupo religioso bem estabelecido têm uma vida social mais rica, mais integrada na sociedade dele. Então eu acho que não é só a crença isolada que faz isso. Eu acho que a crença ajuda isoladamente em momentos mais reflexivos/introspectivos. Mas eu acho que para a pessoa faz diferença, sim, ter uma religião/fé. Seja qual for eu acho que ajuda. [...] A crença pela crença eu acho difícil que faça isso. Agora, a pessoa que tem um contato social via religião e recebe visita, tem uma atenção maior, tem alguém para ouvir suas queixas, que se sente acolhida... (M10).

Eu acho que funciona na medida em que várias pessoas se beneficiam com aquele suporte religioso, principalmente a pessoa que é dependente. Isso acontece muito. Aquelas pessoas que têm dificuldade de controle de impulso acabam se beneficiando de religião por causa dos dogmas. Aquelas pessoas que não têm meio termo. É sim ou não. Ou acredita ou não acredita. Então, acaba que uma série de pacientes se beneficiam dessa coisa mais estruturada, desse ambiente com normas mais estabelecidas que você tem que cumprir, pronto e acabou. (M6).

Professam-se também outras ideias como as de que a religião: faz com que o paciente sinta-se mais acolhido (M6)/ mais amparado (M10); dá uma perspectiva de futuro (M22); está relacionada com vida saudável $(\mathrm{M} 12)^{275}$; é um "fator protetor para a doença mental" (M4, M11, M25). Neste último caso, acredita-se que "as pessoas que possuem uma religião têm menos doença mental” (M11). Resgatam-se, então, os exemplos clássicos que são: a relação entre falta de religião e maior risco de suicídio, a religião como forma de sair do isolamento.

275 Frisa-se, porém, "uma religiosidade normal" (M25); em outras palavras, uma religiosidade "saudável". 
A opinião de que a fé do paciente pode interferir no processo de cura (M4) não é apanágio da religião ${ }^{276}$, há psiquiatras que apontam possibilidades outras: "desde a fé numa crença religiosa até a fé de que o remédio pode ajudar" (M15). Ou seja, a fé pode dar-se em direções diversas. Uma delas diz respeito a uma fé abrangente que não se prende ao domínio do sagrado/transcendental e muito menos às formas clericais (M16, M22, M10, M17, E1, E2). Assim, não importa qual (pode ser religiosa ou não) o tipo de crença (M4, M22, M16), a "fé é a melhor palavra" (M15, M4): "O paciente que tem fé evolui melhor do que o paciente que não tem" (M16). Por vezes, pondera-se bastante antes de concluir sobre os possíveis e tão propalados benefícios trazidos pela religião - "Parece um dogma: 'as pessoas melhoram a partir da religião!'. Parece uma coisa meio dogmática, mas será que melhora mesmo? Eu não sei, não tenho essa resposta, não" (M6). De outro modo, pode haver dogmatismo ao se afirmar que o paciente melhora a partir do remédio, como faz a medicina psiquiátrica.

Entretanto, ainda assim, consegue-se enumerar algumas vantagens visíveis a ela conferidos: pode ajudar a controlar os sintomas (M9); prega um estilo de vida terapêutico $(\mathrm{M} 9, \mathrm{M} 12)^{277}$. A lista é extensa, a religião pode ainda: regular "os problemas da vida", tornando-os mais toleráveis (M14, M19); dar mais esperança e conforto (M9); dar sentido de futuro (M22), ajudar a lidar melhor com a doença (M11, E3). Os profissionais percebem que as pessoas são sugestionáveis - aí reside a brecha para a atuação da religião - e em certas ocasiões isso é positivo, no sentido de ajudar a "passar por situações de vida difíceis" (M21) ${ }^{278}$. No caso de pacientes terminais, por exemplo, a religião proporciona uma "outra visão em relação à morte" (E4) e esse entendimento faz com que as pessoas sofram menos (E4). De um modo geral, ela também é apontada como importante para que alguns pacientes mantenham o elo com a vida ao evitar possíveis tentativas de suicídio (M7, M16, M19, M21, M24), por exemplo. É anuência entre os profissionais o fato de que os pacientes que nutrem uma fé em algo, que têm uma espiritualidade acabam sendo mais aferrados à vida: "Pacientes suicidas, um dos critérios que a gente usa para ver

\footnotetext{
${ }^{276}$ Não obstante, essa perspectiva está presente em alguns relatos que creditam à religião esta qualidade: "Eu acho que a pessoa que tem essa fé viva, por meio da fé ela recebe ajuda de Deus. Ela tem uma confiança de que Deus vai lhe ajudar" (E10).

${ }^{277}$ No sentido de combater a doença. Por exemplo, as normas da Igreja, a disciplina pode ajudar um dependente químico.

${ }^{278}$ Para pacientes psiquiátricos considera-se discutível, mas, para pacientes terminais, acredita-se na eficácia (M12).
} 
a potencialidade de executar o ato é a religiosidade, a religião" (M19). Ou seja, a religião pode ser vista como impeditiva do ato suicida.

O que parece ser consenso é que, de alguma forma, há uma mobilização de forças interiores (M23) que ajudam o paciente. O suporte psicológico, que é promovido pela religião, não pode ser desconsiderado (M26), ela ajuda a melhorar o emocional (E1), tranquiliza, acalma (E3, E5, M7), proporciona conforto espiritual (M19, M9, E4, E5, E7, E10), traz mais segurança (E10), abarca o sujeito (M24). Ou seja, a questão religiosa pode ser muito importante não necessariamente na eliminação do sofrimento, mas na sua melhor administração (M22); isso pode ocorrer porque ela possibilita uma mudança com relação ao foco da doença - que se desloca do sofrimento para a crença (E4). Assim, a religião ajuda na amenização do sofrimento, este não obrigatoriamente deixará de existir, mas será ressignificado. A religião, considerada "a instituição mais antiga" no proporcionamento de "suporte psicológico para as pessoas que sofrem" (M26) - mediante seus métodos particulares, obviamente -, "tem uma continência no sentido de abarcar, segurar, envolver, engolfar o paciente" (M24).

Resumindo, a religiosidade traz consigo duas possibilidades na visão dos profissionais: ela pode tanto integrar o indivíduo quanto o contrário. Essa dupla face a ela atribuída pode estar associada ao caráter ambíguo que predomina entre os entrevistados. Nos extremos da ambigüidade da religião, as atuações são distintas, variando, por um lado, de "função integradora do indivíduo na sociedade" (acalma conflitos internos, apazigua a exclusão social, continente para a expressão psicopatológica) e, por outro lado, de "função desintegradora" (agrava o sintoma psíquico, desampara mediante questões como culpa e pecado). Tal anfibologia pode estar relacionada, de um lado, à história social e emocional do sujeito e, de outro lado, à interpretação que a sociedade dá ao que ele sente: "manifestação psicopatológica ou cultural" (MACHADO, 2001, p. 115). 


\title{
5.2 A RELIGIÃO dOS PSIQUIATRAS E A RELIGIÃO PARA OS PSIQUIATRAS
}

\begin{abstract}
Eu não sei se você consegue perceber isso, mas as pessoas que fazem psiquiatria geralmente são diferentes das pessoas que fazem as outras áreas da medicina. São pessoas que já são mais críticas. Que se colocam de forma mais crítica em relação a determinados valores. (M14).
\end{abstract}

Dos médicos entrevistados, apenas um se denominou ateu e mesmo assim fez referência à sua formação familiar católica e à importância do templo enquanto "lugar de paz", que lhe possibilita fazer reflexões, acalmar-se; colocar o "resto do mundo à parte" (M19). Alguns se denominaram sem religião (M2, M4, M6, M9, M10, $M 11, M 17, M 21)^{279}$ e outros agnósticos (M14, M15), destes últimos, um chegou a frequentar a Igreja Católica e o espiritismo kardecista até a adolescência, quando foi tornando-se "cada vez mais agnóstico" e distanciou-se da religião: "Cheguei a ter um período de negar completamente, de ter horror à religião, falar mal, mas com o tempo eu acabei tendo uma posição mais conciliatória" (M14). Este último encara a religião, por meio das cerimônias, como uma forma de entrar em contato com outras pessoas, mas não acredita que haja nela uma força transcendente: "Eu acredito no rito, mas não acredito no mito" (M14).

M14, M16, M17 e M22 acham que, de um modo geral, os colegas psiquiatras ou não têm religião ${ }^{280}$ ou são ateus (M14, M16, M22) ou têm preconceito de religião 281 (M16): "Tem muito médico psiquiatra ateu. Ateu mesmo, que despreza qualquer forma de religião e que chega a condenar, mesmo. [...] Eu acho que a

\footnotetext{
${ }^{279}$ Destes, um é psiquiatra mono-posicionado e sete são psiquiatras neutros. Alguns trechos podem ilustrar o posicionamento deles: "Eu acho mesmo que existe uma explicação celular darwinista" (M21)/ "Eu costumo dizer que a minha religião é Spinoza, não acredito em alguma coisa além" (M6)/ "A religiosidade é a esperança de que o princípio de justiça, de compensação de alguma forma tenha uma ascendência sobre o universo" (M10)/ "Não sou ateia, eu acredito em uma coisa maior, controlando as coisas" (M17).

${ }^{280}$ Há uma diferença entre autodenominar-se sem religião e autodenominar-se ateu. $\mathrm{O}$ ateu não crê na existência de Deus e pode ser contra ou não à religião/religiosidade, já o sem religião pode crer na existência de Deus (imanente ou transcendente) ou deuses, mas pode simplesmente não se considerar vinculado a nenhuma instituição ou pode, no momento, não ter religião.

${ }^{281}$ Afirmar que se tem preconceito de religião parece diferente de se considerar ateu ou de se considerar sem religião. A pessoa pode ter preconceito contra religião enquanto instituição, mas ser favorável à espiritualidade, à religiosidade.
} 
proporção de médicos ateus é mais na psiquiatria do que em outras áreas da medicina" (M14). No entanto, acredita-se que, em geral, haja uma diversificação de atitudes que varia do mais ao menos religioso, culminando no ateísmo: "Eu sei que existem ateus, agnósticos, evangélicos, espíritas, católicos. Eu sei que tem de tudo. $\mathrm{Na}$ psiquiatria, pelo menos" (M15). São possíveis diferentes combinações em se tratando de religião/religiosidade. Por exemplo, existe o profissional que se diz de tal ou qual religião e que, ao mesmo tempo, afirma que práticas religiosas não existem na sua vida atualmente (M5 - Católico). Ou aquele que sustenta que "na teoria" tem religião (M3), pois foi batizado na Igreja ortodoxa e frequentou quando adolescente, com o tempo desinteressou-se, não segue nenhuma religião; porém, também não se considera ateu - passou a ler sobre algumas religiões a título de conhecimento apenas: "Não era um interesse religioso, era uma coisa mais da parte filosófica do pensamento, aquilo acho que é bem legal" (M3).

Os informantes que disseram que a religião é importante ${ }^{282}$ justificam-se afirmando que ela: dá um sentido para sua vida (M7); tem conceitos como o de fazer o bem ao outro que considera importante (M8); move enquanto ideal, ela integra tudo que se faz na vida (M13); é importante não só no sentido do culto, mas de ter fé em algo maior (M16); atrai mediante sua simbologia $(M 22)^{283}$; é algo que não te diz como agir, é só uma maneira de encarar a vida $(\mathrm{M} 24)^{284}$.

Alguns afirmaram ter religião sem especificamente atribuir a ela um valor particular em suas vidas: foram socializados, porém não praticam ( $M 3, M 18, M 20$, M25, M12, M26). Há os que acreditam que quanto maior o nível de escolaridade do médico mais ele tem propensão a não acreditar e, por consequência, a não achar necessário abordar questões relacionadas à espiritualidade do paciente. E mesmo os que têm uma religião a separam muito bem da ciência, "não acham que sejam coisas que possam se juntar. Então eles conseguem, ao mesmo tempo, ser médicos no hospital e ir à igreja. Como se elas fossem duas coisas completamente separadas e distintas. Eu acho isso também incrível! [...]" (M13). De um modo geral - e aí se toma como referência pesquisas realizadas nos EUA - acredita-se que quanto mais estudo tem o médico, mais ele tem uma tendência a não abordar a

\footnotetext{
${ }^{282}$ M7, M13 e M24 são espíritas. M16, M22 são católicos e M8 é protestante.

${ }^{283}$ "Se você for na minha casa você vai ver artigos religiosos católicos, espíritas, de índios, xamanistas" (M22).

284 "Não tem certo ou errado no espiritismo. Por isso que eu gosto" (M24).
} 
questão da espiritualidade, a desacreditar, ou achar que é uma coisa irrelevante (M13). A despeito dessas conclusões, M13 acredita que a grande maioria dos médicos brasileiros tem uma vivência religiosa.

Talvez isso possa explicar-se pelo fato de a psiquiatria estar inserida num contexto mais amplo do mundo intelectual, no interior do qual, normalmente, é emblemática a questão do avanço científico como sendo inversamente proporcional à força dos mitos. Há uma tendência a esse tipo de pensamento - o qual norteia grande parte de intelectuais das diversas áreas - e que se traduz em: "de um lado, um saber 'mitológico' leve e ambivalente e, de outro, o saber 'objetivo' do naturalista médico"285 (LAPLANTINE, 2004, p. 216).

Eu não acho que a resistência é só médico-psiquiatra, eu acho que é dos acadêmicos em geral. É uma teoria pessoal minha: acho que no meio universitário como um todo há uma resistência muito grande e há um certo mito construído meio estereotipado de que religião está ligado a intolerância, dogmatismo e anti-ciência e que a ciência, para ser ciência, tem que ser materialista, antirreligiosa, etc... E essas coisas não se misturam de jeito nenhum. Existe um mito nesse sentido até porque essa resistência existe em qualquer área. Quer dizer: em várias áreas a gente sabe... na área de ciências humanas também a gente tem bastante resistência nessa área, também na área de saúde, etc... (M1).

Possuindo ou não religião, os psiquiatras não se isentam de duras críticas com relação a um modo obtuso de pensar. Tem-se a autocrítica de a própria medicina ser considerada como uma religião pelo médico, "uma coisa meio dogmática" (M3). Alerta-se, por vezes, quanto às diferenças primordiais entre o que quer a religião e o que pretende a ciência - uma baseia-se na fé, a outra no método investigativo - e do fato de que uma fé cega na ciência também pode ser prejudicial e desvirtuar o seu sentido último investigativo: "Muitas vezes é uma questão de acreditar, se você fica com fé na ciência perdeu-se o princípio da ciência, da verdade que é desconfiar de tudo, tentar investigar tudo. Se você simplesmente diz 'acredito nisso', aí vira dogma, deixa de ser ciência e passa a ser religião". Ou seja, não existe uma verdade absoluta, mas sim diferentes modalidades de verdade, diferentes

\footnotetext{
${ }^{285}$ Aí Laplantine (2004, p. 215) faz referência, especificamente, às considerações do psiquiatra Henry Ey (1981) para quem existe uma verdadeira medicina e uma falsa (esta também denominada mágica, mitológica, sacerdotal, pseudomedicina). Segundo o referido psiquiatra, é necessário desmitologizar a doença: "Arrancar' a doença da religião, da filosofia e das ciências humanas a fim de resgatar uma 'ordem natural'”.
} 
modos de interpretação (M6). Os cientistas devem estar atentos, então, à questão da flexibilidade - e da "reflexividade", nos termos de Bourdieu, no que concerne ao campo científico - necessária quando se trata do conhecimento não religioso.

Entre os enfermeiros, na situação religiosa atual, tem-se: o católico (E1), o que diz apenas acreditar em Deus (E2), o evangélico da Congregação Cristã (E3), o espírita Kardecista (E4) que não frequenta, mas que afirma ter tido "uma formação mais focada na questão da espiritualidade". Tem E5, que diz ter sido ensinada a ser católica, mas tem uma relação diferente com a religião em que acredita não ter que ir à igreja para encontrar Deus: "Eu já pensei tanto sobre religião e defini que agora eu sigo a minha ideia, o meu Deus" (E5). Há também a católica praticante que afirma ser extremamente apegada a Deus a ponto de ir à missa todo domingo, acreditar muitíssimo em Nossa Senhora, em anjo da guarda e gostar de ler salmos (E7). Há aquele que se considera católico, mas frequenta a Congregação Cristã (E9), o que é frequentador da Igreja Evangélica Brasil para Cristo $(E 10)$ e para quem a religião é o suporte de tudo: "Para mim é a base da minha vida. É acreditar que o que vivemos hoje é passageiro e que há uma esperança de algo melhor. De algo eterno" (E10). Há o católico esporádico (E8), o que vai à missa de sétimo dia e casamento e que frequenta a Igreja Evangélica Renascer em Cristo (E11).

Alguns enfermeiros pensam que os colegas, de um modo geral, são heterogêneos em relação à religião: uns acham que a maior parte acredita em Deus (E1); outros acreditam que é dividido, com alguns não acreditando e outros acreditando e tendo religião (evangélicos, espíritas, católicos) (E4); e tem os que acham que há profissionais de religiões diversas (E11).

Para os médicos, a religião tem significados diversos. Numa visão pessoal, ela é tida para pensar na lógica da vida: "É uma forma de pensar como vai ser, o que vai acontecer. Para mim a religião é muito mais uma maneira de tentar explicar o que acontece depois, [...] usar a religião para poder, de uma maneira até um pouco metafísica, pensar na lógica da vida e tudo o mais" (M24). Nesse sentido, ela possui o atributo mais voltado para a ideia de "um espaço muito interessante para a reflexão filosófica" (M26). Já na perspectiva de alguns enfermeiros, a religião dá a possibilidade de construir ideias sobre a finitude, o que proporciona conforto espiritual, pois a concepção de uma outra dimensão onde se pode vivenciar uma vida espiritual não somente fornece tranquilidade ao sujeito, mas também incentiva o 
respeito ao próximo (E4). Alguns chegam a admitir que dependem da religião, de Deus para levar a cabo as suas atividades do dia a dia (E11).

Pode-se notar uma característica comum entre os psiquiatras: normalmente, não abrem espaço para a proposição de crença num ser transcendente. $O$ que parece notória é uma atitude de desvinculação institucional (isso mesmo entre aqueles que anteriormente tiveram uma formação religiosa), de abertura para algo que se aproxima de um conhecimento filosófico. Algumas religiões aparecem como sendo próximas dessa ideia, caso do budismo e do espiritismo. Este último, ao ser encarado não como algo que diz como agir, mas simplesmente como uma maneira de encarar a vida (M24). Provavelmente, resida aí o estranhamento - que irá aparecer ao longo das entrevistas - quanto ao uso do termo "religião" e a preferência por expressões como "religiosidade", "espiritualidade" 286.

\subsubsection{Religião, religiosidade ou espiritualidade? ${ }^{287}$}

Existe uma polêmica em relação a qual é a expressão mais coerente quando se trata de crenças espirituais ${ }^{288}$. Assim, os informantes, frequentemente, mostramse atentos ao que consideram como sendo formas distintas de falar do transcendental, quais sejam: religião, religiosidade, espiritualidade. Elas são aparentemente semelhantes, o que pode conduzir ao seu embaralhamento, porém são distintas (M4). Nesse sentido, acredita-se ser necessário "usar a religiosidade e não a religião" (M7, M26, E4, M6), ou que a questão é a espiritualidade e não uma religião específica (M13, M21, E8, M20).

No intuito de fazer notar que o importante é o contato com algo superior, que não necessariamente seria considerado uma religião, coloca-se como exemplo o grupo dos "Alcoólicos Anônimos (AA)". Este é análogo à religião, os pacientes

\footnotetext{
${ }^{286}$ Ao longo das entrevistas, quando a pesquisadora empregava o termo religião, os informantes (em especial, os psiquiatras) procuravam fazer a diferenciação entre religião, religiosidade $e$ espiritualidade, evidenciando ser mais apropriado o emprego das duas últimas.

287 Psiquiatras ( 3 bi-posicionados, 6 neutros) e enfermeiros (4 neutros, 1 bi-posicionado) trazem à tona a questão da fé em oposição à religião.

288 No I Simpósio Paulista: Saúde, Espiritualidade e Educação, palestrante afirma ser "mais politicamente correto" falar em espiritualidade do que em religiosidade.
} 
beneficiam-se muito do contato com aquele grupo, na medida em que ele faz referência a um poder superior, tem uma organização moral rígida, apoiada nos doze passos ${ }^{289}$ (M4). Assim, considera-se que o mais adequado é - para além de concepções como religião, religiosidade, espiritualidade - a ideia da "fé", da crença não importa no que seja ${ }^{290}$. Isso, talvez, em vista do que alguns estudos têm apontado por meio de pesquisas com placebo ${ }^{291}$ mediante as quais se evidencia que crença/fé/confiança não é um atributo religioso. Dessa forma, faz-se necessário levar em consideração o que o paciente traz em relação a esses conceitos no sentido de incentivá-lo "a fazer o que ele acredita" (M17), atentando sempre para o fato de que, acima de tudo, o importante não é ter "necessariamente religião, mas uma referência" (M17). A religião em si é colocada em contraste com as seguintes propostas: a fé (E5); a crença em algo superior que protege (M24, E2, E8).

Esses casos assemelham-se à religiosidade no sentido da "religião mística" da qual fala Troeltsch (1958). Esse autor, ao analisar a relação entre modernidade e religião, introduz uma terceira modalidade ${ }^{292}$ para entender a dinâmica religiosa moderna: a "religião espiritual e mística", a qual seria "uma religiosidade antiinstitucional que extravasa as fronteiras das igrejas, não radicalmente racionalizada, já que é mística, e não ascética, porém individualizada e com fortes tendências sincréticas e pluralistas" (TROELTSCH, 1958 apud NEGRÃO, 2008, p. 116). Uma crise na religião eclesiástica ${ }^{293}$ e a abertura para uma religião individualizada (não clerical) foram mudanças que chegaram junto com a modernidade e com todas as modificações resultantes desta.

Religiões que aparecem como fontes da religiosidade individual são apresentadas como filosofias. Isso mostra tratar-se da "ênfase, portanto, não na verdade revelada e dogmática, mas em filosofias orientadoras da conduta individual" (IBIDEM, p. 129). Essa mudança de configuração não coloca totalmente de lado,

\footnotetext{
289 "Os Doze Passos de A.A. consistem em um grupo de princípios, espirituais em sua natureza que, se praticados como um modo de vida, podem expulsar a obsessão pela bebida e permitir que o sofredor se torne íntegro, feliz e útil. Não são teorias abstratas; são baseadas na experiência dos êxitos e fracassos dos primeiros membros de A.A" (Disponível em $<$ http://www.alcoolicosanonimos.org.br> Acesso em 01/03/10).

${ }^{290}$ Muitas vezes apoiado na ideia, frequentemente utilizada, de que "todas as religiões vão para um caminho só" (E11).

${ }^{291}$ Conforme lembrado pela professora Maria Helena Villas Bôas Concone, em defesa do relatório de qualificação da presente tese.

${ }^{292} \mathrm{O}$ autor já havia tratado pormenorizadamente de outros dois tipos, Igreja e seita.

${ }^{293}$ Troeltsch (1958) refere-se ao período da passagem do século XIX ao XX.
} 
entretanto, as tradições religiosas, a estas se remete de alguma forma: "essa ausência de exclusivismo sectário abre a possibilidade de construção dos mais variados sistemas próprios e alternativos às religiões institucionalizadas, ao mesmo tempo em que, paradoxalmente, as legitima, por se reportar às suas tradições" (TROELTSCH, 1958 apud NEGRÃO, 2008, p. 129). Entre os psiquiatras entrevistados, por exemplo, o contato com as religiões pode acontecer não mediante a presença física, mas através da simples leitura de livros que falem a respeito da temática, com o argumento de apenas querer obter conhecimento.

O que ocorre, a olhos vistos, é que "as religiões não mais se esgotam nas igrejas" (IBIDEM), existem construções religiosas personalizadas que ultrapassam as fronteiras do clericalismo tout court. Essa mudança faz pensar que o universo religioso é transformado continuamente na direção da rejeição do clericalismo e da adoção da individualização. Esses são fatores que se fazem notar muito claramente nos discursos dos entrevistados. Na literatura médico-psiquiatra, normalmente, as definições destacam a distinção entre religião e espiritualidade. Ainda que essas duas estejam relacionadas, alerta-se para o fato de não se tratar de sinônimos. $A$ espiritualidade é definida como "uma propensão humana a buscar significado para a vida por meio de conceitos que transcendem o tangível: um sentido de conexão com algo maior que si próprio, que pode ou não incluir uma participação religiosa formal" (SAAD et al., 2001; VOLCAN, 2003 apud GUIMARÃES e AVEZUM, 2007). Já a religiosidade envolve outras questões como: sistematização de culto e doutrina, as quais são compartilhadas por um grupo (IBIDEM).

[A religião seria] um sistema organizado de crenças, práticas, rituais e símbolos delineados para facilitar a proximidade com o sagrado e o transcendente (Deus, Poder Maior ou Verdade/Realidade Final/Máxima) e a espiritualidade uma busca pessoal por respostas compreensíveis para questões existenciais sobre a vida, seu significado e a relação com o sagrado ou transcendente que podem (ou não) levar a ou resultar do desenvolvimento de rituais religiosos e formação de uma comunidade. (KOENIG et al, 2001 apud PANZINI et al, 2007).

Existem análises mais recentes que, na linha do pensamento de Troeltsch, realizam uma reflexão voltada para os tempos atuais. Nessa perspectiva, estaria ocorrendo, entre nós ocidentais, um processo de "orientalização", o qual se caracterizaria especificamente "pelo deslocamento da teodicéia tradicional por outra 
que é essencialmente oriental em sua natureza" (CAMPBELL, 1997, p. 5). O que representaria uma mudança de teodiceia ${ }^{294}$ e junto com esta, a substituição da crença em um Deus transcendente e pessoal pela concepção de um Deus imanente e impessoal, a qual se caracteriza por "atitudes religiosas místicas não salvacionistas, de auto-aperfeiçoamento ou de auto-deificação (cujo exemplo histórico mais acabado é a lei cármica hindu)" (NEGRÃO, 2008, p. 117).

Interessante a colocação de Campbell, ela faz com que se conjecture sobre o possível sucesso "de uma religião de misticismo troeltschiano" entre os psiquiatras, ou ainda como pretende o autor, a provável predominância da teodiceia ${ }^{295}$ oriental em meio a esses profissionais. A vantagem da teodiceia oriental sobre a ocidental residiria na menor vulnerabilidade da primeira aos ataques da ciência ${ }^{296}$ e na sua compatibilidade com o pensamento moderno representada pela "aparente abertura e individualismo" (CAMPBELL, 1997, p. 18). Portanto, o seu sucesso reside muito possivelmente no fato de - mediante questões como "o individualismo extremo, juntamente com o antidualismo e a relativização das pretensões de verdade" (IBIDEM) - essa teodiceia ser um "alvo muito difícil para o ataque dos racionalistas e cientistas" (IBIDEM).

Os psiquiatras (sejam os bi-posicionados, sejam os neutros/ambíguos) apoiam-se, pois, num modelo religioso mais descentralizado, fluido, não vulnerável aos ataques da ciência. Eles, enquanto cientistas, procuram esquivar-se dos ataques desta no âmbito religioso. Ou seja, conhecedores dos critérios científicos, sabem muito bem das incompatibilidades destes com o mundo religioso. Para assegurar não serem eles mesmos "alvos do seu próprio veneno", valem-se de uma mentalidade religiosa resguardada da fúria científica. Assim, participam de um

\footnotetext{
${ }^{294}$ O que, segundo Negrão (2008, p. 117), não significa uma influência direta da religiosidade oriental sobre a ocidental, trata-se sim de um processo de "transformação do próprio campo religioso ocidental pós-moderno", ocorrida graças a aspectos religiosos minoritários que ganham importância "por sua maior compatibilidade com os rumos das transformações societárias". Também pode ser interpretado em relação ao fato de tratar-se de "religiões monistas que encaminham para a aceitação de um relativismo religioso", no qual diferentes verdades religiosas são reconhecidas (CAMPBELL, 1997, p. 12). Dessa forma, "não apenas são toleradas visões largamente diferentes das verdades centrais do cristianismo, mas todas as formas de religião são vistas como idênticas" (IBIDEM).

${ }^{295}$ Faz-se necessário, aqui, explicar como o paradigma oriental sobressaiu-se no Ocidente. Isso aconteceu devido ao surgimento da ciência e por esta haver minado, em primeiro lugar, a fé na religião tradicional e, na sequência, por ter dissipado o otimismo relacionado à ciência e à tecnologia (IBIDEM, p. 18).

${ }^{296}$ Visto que não é baseada em verdades literais, históricas. (IBIDEM).
} 
mundo científico e de um mundo religioso, seguros de que ambos não irão defrontarse.

\subsubsection{Religião: esfera da intimidade ${ }^{297}$}

Muito provavelmente relacionado ao aspecto místico/não clerical, que caracteriza o modo como os psiquiatras experenciam o sagrado; a religião é colocada, por vezes, como algo estritamente referente à esfera da intimidade de cada um. Denota-se isso nas expressões "privado", "individual” (M6, M18), "pessoal” (M4, M8, M18): "de foro absolutamente privado e estrito do paciente" (M4); "acho que isso é uma coisa tão pessoal!" (M25).

O alerta quanto ao caráter íntimo da religião aparece nas afirmações de que o médico deve tomar cuidado quanto a falar de religião com o paciente, pois se deve levar em consideração: 1) a formação religiosa de cada $u^{298}$ e a "dificuldade interna" associada a isto (M21) com o agravante da real chance de o profissional que é religioso fazer proselitismo (M13); 2) a possibilidade de dar valorização excessiva $^{299}$, quando qualquer demonstração de interesse (em relação à religião/religiosidade do paciente) pode imputar valor, sugerir importância (M4); 3) o fato de estar despreparado para falar sobre algo tão delicado e a necessidade de conhecer as religiões para abordá-las: "O médico não pode falar de religião sem ter conhecimento de como abordar" (M13).

Por ser algo tão individual e delicado, deve-se procurar não estimular essas conversas (M8). Além do que, acredita-se que o psiquiatra, diferentemente do restante dos médicos, deve ter uma postura mais neutra frente ao doente (M8, M17). Ele deve não influenciá-lo (M17), procurar não se intrometer nessas questões (M9), cada um com os seus valores (M25): "as minhas crenças, para o paciente, não valem. [...] Eu acho ruim a gente ter essas valorações, conceitos de valor" (M24). O

\footnotetext{
297 Psiquiatras (2 mono-posicionados, 2 bi-posicionados, 11 neutros) e enfermeiros (1 bi-posicionado, 4 neutros) abordam a questão.

${ }^{298}$ Desse modo, pode ser complicado tanto para o médico quanto para o paciente falar sobre, já que cada um tem a sua religião.

${ }^{299}$ No sentido de desprezar outras variáveis que podem ser tão importantes quanto à religião.
} 
caráter privado, pessoal das crenças dificulta até mesmo a possível ideia de que seja proporcionado algum tipo de formação voltado para esses aspectos ao longo do curso de graduação dos psiquiatras ${ }^{300}$.

Abordar a questão religiosa - seja entre médico e paciente, seja entre os profissionais de saúde - pode gerar conflitos, pode trazer incômodo no sentido da existência de diferenças e do que é socialmente aceito para ambas as partes envolvidas num diálogo. Isso pode resultar na tentativa de desqualificar "desmerecer a religião do outro" (M9) - o que se considera como um tipo de crença errada e querer impôr aquilo em que se crê (M3). Por isso, às vezes, é melhor não tocar no assunto, pois facilmente pode haver desrespeito (M9), "religião é difícil de discutir" (E9). Finalizando, como afirma M25, a religião tem muito de visão pessoal: "Às vezes a pessoa fala de um jeito e a outra quer do outro, sai briga. Religião, para sair briga!". Assim, reforça-se a tão propalada "crença"301 de que religião é "bom nem discutir" (M25). Como lembra Pierucci \& Prandi (1996), "o conflito religioso faz parte da vida e é por isso que 'gosto e religião não se discute'”.

Assim, é possível que haja uma dificuldade do psiquiatra em falar de questões religiosas quando ele mesmo possui uma crença qualquer. Torna-se dificultoso para esse profissional entrar no mérito de outras crenças que sejam incompatíveis com as suas, às vezes pode ser incômodo (M3), pois "tem os preconceitos do que você acha da sua religião, o que está determinado pra você" (M21). Ao mesmo tempo, por não ser religioso, o psiquiatra pode não sentir que haja necessidade para o paciente: "Nunca tive uma presença religiosa importante na minha vida, acho que é mais uma questão pessoal e talvez por eu não sentir essa demanda e por não ver nos pacientes essa demanda" (M15). Por ser questão pessoal, a abordagem da religião vai depender de como o profissional a encara, qual o significado a ela atribuído.

Entretanto, é recomendável manter-se informado sobre essa questão tão polêmica. Por isso mesmo, no momento da anamnese do paciente, ela deve ser investigada (M14, M15, M21), pois pode ser uma aliada no tratamento, um dado

\footnotetext{
${ }^{300}$ Os relatos dos informantes confirmam esse fato: "Acho que tem que ter para quem gosta, para quem quer se aprofundar" (E4)/ "Precisa ver o quanto a pessoa está envolvida, o quanto a pessoa quer e acredita, depende dos valores, das crenças" (E5)/ "Dependendo do que for colocado, tem pessoas que não creem em Deus, não creem em nada [...] Seria um pouco forçoso" (E10)/ "Como cada um teve uma doutrina diferente no seu crescimento, em sua cultura, é muito difícil" (E11).

${ }^{301}$ Conforme reza o dito popular de que "religião, política e futebol não se discutem".
} 
relevante (M15) no sentido de: "Entender o que o paciente está falando" (M9); saber discernir uma prática religiosa de um sintoma (M9, M17, M21, M13); ser uma ferramenta terapêutica que une o paciente e o médico (M10). Frisa-se, porém, que a priori não é função do médico tratar desse assunto com o paciente (M10).

Além do benefício de se manter informado sobre a religiosidade do paciente para a compreensão da doença, esse conhecimento ajuda em termos de um maior respeito pela crença do paciente, um maior discernimento (E4). As dificuldades de respeitar, entender ou até mesmo abordar a questão religião/ religiosidade/ espiritualidade estão mormente relacionadas ao fato de esta temática aparecer, normalmente, descolada da prática médica (M13, M18, M25). A despeito dessa realidade, há os que pensam que se o paciente falar de assuntos relacionados à fé/religião com o médico, este tem obrigação de saber falar disso com o paciente (M24). Assim como nada impede que uma conversa sobre o tema "religião" seja iniciada pelo profissional: "Não é tabu" (M12). Acredita-se que todo psiquiatra tem que ter uma concepção sobre o homem e deve ser dada ao paciente a oportunidade de saber qual é esta concepção (M14).

\subsubsection{Demanda religiosa e/ou demanda psiquiátrica? ${ }^{302}$}

Qual é, de fato, a "verdadeira" demanda por parte dos pacientes? Uma demanda exclui a outra? Ou elas podem sobrepor-se? A verdade é que as demandas psiquiátricas e religiosas podem ser concomitantes, a despeito da concorrência que as separa. Isso porque “não existem práticas puramente 'médicas' ou puramente 'mágico religiosas', mas no máximo, recursos distintos, [...] dois níveis interpretativos estreitamente ligados" (LAPLANTINE, 2004, p. 217). Ao se alertar para a necessidade do tratamento conjunto ${ }^{303}$, medicamentoso e religioso, a ideia é

302 Psiquiatras (1 mono-posicionado, 5 bi-posicionados, 13 neutros) e enfermeiros (3 neutros) abordam a questão.

${ }^{303}$ O psiquiatra mono-posicionado contesta essa ideia: "O diálogo entre o médico e o religioso direto, no sentido de uma atuação conjunta, eu não vejo necessidade". (M15). 
que o aspecto religioso atue, sobretudo, no sentido de ser um aliado ao tratamento (M7, M6), uma complementação (M22) ${ }^{304}$.

Grande parte dos psiquiatras (alguns neutros/ ambíguos, outros biposicionados) $)^{305}$ aprova a religião como forma alternativa, mas conjunta com a psiquiatria; ou seja, eles concordam que a religião seja importante, mas sempre em associação com o tratamento médico. Como já visto, os psiquiatras aprendem no início da faculdade que devem perguntar sobre a religião na etapa de anamnese. É possível concluir que essa questão, então, tem alguma importância na vida dos pacientes - "É muito comum o paciente falar da religiosidade dele, da crença, do que ele espera" (M9) - bem como na forma como o psiquiatra irá dar andamento ao tratamento. Deve-se estar alerta à possibilidade de "uma demanda religiosa além, apenas, de uma demanda medicamentosa" (M5). O paciente psiquiátrico pode ter necessidade de conversar sobre questões relacionadas à religiosidade (E2) até mais do que outros pacientes clínicos (M1). Há pesquisas, segundo M1, indicando que "os pacientes internados em psiquiatria referem necessidades espirituais desde conversar sobre questões religiosas, dúvidas ou precisar de apoio, conforto religioso".

Existem aqueles profissionais que falam da possibilidade de o paciente sentir-se mais confortável tendo "uma abordagem dupla" (M9). Outros chegam a afirmar, até mesmo, que se busca o profissional de saúde mental como "último recurso terapêutico" (M8, M14) ${ }^{306}$. Acredita-se que a comunidade e seus recursos que varia de familiares e vizinhos a igrejas - sejam bem eficazes, podendo exercer um papel importante na filtragem do sofrimento até mesmo antes dele chegar ao psiquiatra, o qual acaba sendo o último a ser procurado ${ }^{307}$. Na rede de ajuda mútua,

${ }^{304}$ Os seguintes depoimentos ilustram a questão: "Acho que a religião é importante, mas a pessoa não pode excluir o tratamento, tem que ser uma coisa mesmo conjunta" (M7)/ "Se aquilo [a religião] está trazendo um bem-estar, então está ótimo! Eu só não descarto a ideia de a pessoa receber também o tratamento convencional". (M6).

305 O psiquiatra mono-posicionado, ao contrário, não percebe nenhuma demanda religiosa: "Sinceramente, na psiquiatria, nunca senti essa demanda por parte dos pacientes nem nunca surgiu espontaneamente para mim essa demanda [...]. (M15).

${ }^{306}$ Alguns psiquiatras, muitas vezes, têm preconceito, entretanto, é recorrente que o paciente antes de procurar a ajuda do médico, recorra ao religioso: "Para desespero dos profissionais (que explicam o comportamento popular como ignorância), os indivíduos recorrem a outras explicações, a outras atitudes e a outras estratégias, pois não crêem nas prescrições biomédicas apenas. Por isso, tomam a liberdade de reinterpretar os preceitos eruditos, de integrá-los dentro de suas condições existenciais e, ao mesmo tempo, de prescindir deles ou de subestimá-los [...]". (MYNAIO, 2007, p. 255).

${ }_{307}$ Segundo $\mathrm{M} 14$, até mesmo em relação à medicina, outros profissionais, como o cardiologista, o clínico geral, também antecedem o psiquiatra em prioridade. 
na prática comunitária da igreja, por exemplo, o líder religioso pode ter acesso mais próximo às pessoas que sofrem do que o psiquiatra, por meio de sua prática de atendimento individual no consultório (M14).

Ocorrem casos, não obstante, em que o líder religioso da comunidade percebe, em certos momentos, que a demanda do sujeito não é religiosa, mas sim médica, daí ele encaminha para o profissional da área de saúde mental ${ }^{308}$. Resta indagar se o psiquiatra teria o mesmo tipo de atitude ao detectar uma demanda religiosa no paciente: Ele o encaminharia para o profissional desta área? Assim como o religioso, o psiquiatra estaria aberto à "multiplicidade de discursos" (M14) existente? O fato de se optar por uma ou outra modalidade de especialistas não é nenhum pouco contraditório para a clientela que assim procede. A contradição, se é que existe, só existe quando é vista de fora: "[...] Geralmente, são os olhares do profissional e do acadêmico que vêem aí um problema ou um objeto de reflexão. $A$ clientela, ela mesma, busca respostas" (CONCONE, 2003, p. 47, destaque nosso).

Eu não fiz faculdade aqui, eu fiz faculdade em Salvador. Eu fiz a residência aqui. Lá em Salvador tem um professor que sempre falava, não sei se ele fala mais, que tinha uma mãe de santo que de vez em quando encaminhava pacientes pra ele. Ela falava: "Olha, doutor, isso aqui não é mais do Candomblé. Isso aqui já é da psiquiatria". Eu acho isso muito interessante, a gente pode interpretar isso também de outra forma: "Eu acho que isso aqui não é mais da psiquiatria, isso aí já é do Candomblé”. Eu acho que é se permitir, se deixar aberto para essa multiplicidade de discursos. Eu acho realmente que seria uma pretensão muito grande achar que a psiquiatria poderia resolver todos os problemas. (M14).

Entretanto, ainda que possa haver abertura dos profissionais em detectar demandas $^{309}$, estas quem definirá, de fato, será o próprio paciente (M23), o qual, a partir das suas necessidades, postulará qual o aspecto (religioso ou médico) mais Ihe apraz. Assim, pode-se conceder atendimento religioso a paciente psiquiátrico desde que "dentro de uma demanda específica"310 (M26) e havendo um trabalho

\footnotetext{
${ }^{308}$ Não se pode deixar de mencionar que também ocorrem casos (são vários os relatos de psiquiatras sobre isso), por outro lado, em que o líder religioso exclui a possibilidade de intervenção médica, ainda que esta seja necessária, chegando ao extremo de aconselhar o paciente a não tomar medicação, comprometendo assim a sua saúde e qualidade de vida.

${ }^{309} \mathrm{O}$ profissinal, acredita E7, tem condições de captar "quando o paciente está precisando de um remédio ou quando o paciente está precisando de uma conversa" (E7).

310 "Teve paciente, por exemplo, que eu atendi, que na licença do passeio o que ele queria fazer era ir para a igreja porque fazia muito tempo que ele não ia. É uma coisa que eu acho que estava fazendo falta pra ele" (M18).
} 
conjunto entre psiquiatras e religiosos (M26). De acordo com M7, "os pacientes pedem, procuram" (exemplifica com o caso de paciente que sentiu necessidade de se abrir e contar que frequentava um centro de Umbanda e que isso a ajudava muito); ou seja, se o médico der espaço o paciente colocará questões muito importantes, inclusive religiosas (M14).

Sabe-se, comprovadamente, por intermédio de pesquisas - é recorrente haver referência a pesquisas, principalmente por parte dos psiquiatras biposicionados -, dos benefícios da religiosidade/espiritualidade para a saúde. Munidos com este argumento, os profissionais vinculados ao ProSER têm se mobilizado no sentido de fazer um levantamento das necessidades espirituais ${ }^{311}$ dos pacientes. Há um projeto em andamento mediante o qual será possível obter "dados concretos" com vistas a criar programas - primeiramente no IPQ, estendendo-se futuramente para todo o complexo do HCFMUSP - onde as necessidades espirituais de pacientes e familiares possam ser acolhidas (M27).

Porém, não se deve deixar de ponderar sobre o contexto de utilização ${ }^{312}$ da religiosidade/espiritualidade bem como da sua adequabilidade. Ou seja, deve-se levar em conta que a religião não pode fazer bem a todos em qualquer momento e em qualquer situação ${ }^{313}$, pois, como acredita M27, "nada na vida serve para tudo a qualquer hora", em alguns momentos é indicado, em outros não (E9). A ação religiosa/espiritual tem que estar contextualizada com o todo, ela não pode ser considerada algo absoluto, que está acima da dinâmica. Esse psiquiatra biposicionado faz notar que, no final das contas, mesmo na contestação e no confronto, há uma conformação necessária ao campo psiquiátrico mais amplo com relação a elementos básicos que o constitutem. Com isso, evidencia-se que, no

\footnotetext{
311 Esse levantamento faz parte do projeto do Ambulatório do ProSER, que se encontra - até informações obtidas recentemente - em vias de ser implementado no IPQ. Esse projeto tem por objetivo "promover uma assistência mais integral aos pacientes e seus familiares, assim como humanizar e espiritualizar cada vez mais os profissionais da área da Saúde" (LEÃO, F. C. Publicação eletrônica [mensagem pessoal]. Mensagem recebida por <leaofc@yahoo.com> em 28 jan. 2010).

312 Segundo M27, é necessário saber o momento adequado de intervenção: "Existem até muitos religiosos que mencionam isso. Por exemplo: você está em uma situação de risco de vida, você tem que tomar providências, você não vai poder parar para ficar rezando, por exemplo. Então você vai lá, faz o que tem que ser feito, depois você reza, por exemplo" (M27).

${ }^{313}$ De acordo com M27, dependendo do momento em que é usada pode ser positiva como pode ser negativa: "Existem trabalhos que mostram aspectos negativos da religiosidade/espiritualidade que, no meu entender, são negativos porque são mal conduzidos, impostos, não são feitos da forma adequada ou são feitos na hora errada, do jeito errado e aquilo, ao invés de atingir os objetivos a que se destina, fica um estorvo".
} 
fundo, é necessário fazer o que o campo mais amplo requer, curvando-se a um jogo anterior que nele é jogado e para o qual não se pode estar desatento.

Ou seja, o fato de estar atento à religiosidade ou até mesmo de propiciar o diálogo sobre este tema não anula a visão realista de alguns profissionais em relação ao papel da religião atualmente. Não invalida também a visão pessimista sobre a religião, a qual, como acreditam outros profissionais, tem se desvirtuado da sua ideia inicial enquanto modelo "interessado ou capaz de dar direções para a humanidade como um todo" (M20); ao contrário, tornou-se um "comércio aviltante", onde o "modelo espiritual/ético/filosófico está se esvaindo" (M20).

Além do mais, a religião/religiosidade como fator relevante é encarada, no campo psiquiátrico, como um entre muitos fatores importantes na vida do paciente é o que pensam psiquiatras (mono-posicionados, bi-posicionados e neutros) ${ }^{314}$. Subtrai-se, dessa forma, um quantum de importância que possa, por vezes, ser atribuído a esta variável. Ou seja, não desmerecendo diretamente o fator religioso, os psiquiatras procuram colocá-lo no seu devido lugar: fora do pedestal. Assim como a profissão, a família, o relacionamento amoroso, a sexualidade, entre outras coisas, a religião tem grandes chances de ocupar um lugar de destaque na vida do indivíduo, mas não detém o monopólio deste lugar (M1, M4, M6, M21, M22, M11, M15, M19, E9). Acredita-se que não se deve valorizar a religião como um dado de suma importância. Ao contrário, ela deve ser compreendida "como mais um dado da história do paciente" (M15); em outras palavras, "não é a religião, eu acho que é um conjunto todo das coisas e a religião faz parte" (M17).

Assim, a importância da religião está relacionada à atribuição de valor. Ela não deve a priori estar vinculada ao profissional de saúde, ao contrário, a princípio deve partir do paciente; entretanto, o fato de o médico valorizar esse aspecto não quer dizer necessariamente que ele espere que surja enquanto necessidade do paciente.

\footnotetext{
${ }^{314}$ Psiquiatras (1 mono-posicionado, 2 bi-posicionados, 6 neutros) e enfermeiros (1 neutro) discorrem sobre a questão.
} 


\section{PERCEPÇÃO NO INTERIOR DO CAMPO RELIGIOSO}

\subsection{SERVIÇO RELIGIOSO}

\subsubsection{Alcance: quem conhece?}

A presença religiosa no $\mathrm{HC}$ e no IPQ, especificamente, não é normalmente notada pelos profissionais. Muitos se espantam quando indagados sobre o serviço religioso. A capela é o ponto de referência: alguns se remetem a ela quando consultados quanto ao conhecimento do serviço religioso, outros, mesmo estando informados da existência da capela não associam o termo "serviço religioso" a ela. Entre os psiquiatras e os enfermeiros (mono-posicionados, bi-posicionados, neutros), há os seguintes casos de contato com o serviço religioso:

- Conhecem o serviço religioso ${ }^{315}$ (M1, M2, M5, M6, M7, M8, M10, M11, M12, M13, M15, M16, M17, M23, M25, M27, E9).

- Sabem que existe ${ }^{316}$ (M9, M14, M19, M20, M22, M24, E3, E4, E6, E7, E8, E10).

- Não conhecem o serviço religioso ${ }^{317}$ (M3, M4, M26, E1).

315 Considera-se que conhecem o serviço religioso aqueles depoentes que expressam uma consciência do significado de um serviço religioso estruturado. Dessa categoria fazem parte os que: "conhecem, mas só viram no IC (Instituto Central)"; "conhece e já viu no IPQ"; "conhece e já viu pessoas fazendo esse tipo de trabalho tanto no IPQ quanto no IC"; "conhece o trabalho, já usou e tem bom relacionamento com eles"; "conhece o pessoal da capelania e já viu fazerem um trabalho nas enfermarias em finais de semana". Compõem esse grupo Psiquiatras ( 5 bi-posicionados, 9 neutros, 2 mono-posicionados) e enfermeiros (1 neutro).

${ }^{316}$ Diferenciam-se os que conhecem dos que sabem que existe, visto que estes últimos não associam imediatamente a presença de religiosos a um serviço religioso estruturado. $O$ que sabem é que aparecem alguns religiosos na enfermaria, mas não associam isso a um serviço religioso. Dessa categoria fazem parte os que: "sabem que existe, mas desconhecem como funciona"; "ouviu falar e viu no IC"; "sabe que tem no IC, mas nunca teve contato"; "sabe que existe e tem contato com o padre porque faz parte da comissão de bioética"; "sabe de um padre que passa nas enfermarias"; "sabe de um pessoal que vem cantar no domingo", "já levou pacientes à missa", "já levou pacientes até a capela, mas não sabe como funciona o serviço religioso", "já viu um padre fazer visita"; "já levou pacientes até a capela no domingo"; "já viu visitas de padre e pastor", "sabe da missa que tinha às quartas-feiras". Compõem esse grupo Psiquiatras (2 bi-posicionados, 4 neutros) e enfermeiros (1 biposicionado, 5 neutros).

317 Dessa categoria fazem parte os que: "não conhecem o serviço religioso, mas sabem da capela"; "nunca ouviu falar, mas já viu 'um pessoal cantando"'. Compõem esse grupo Psiquiatras (3 neutros) e enfermeiros (1 neutro). 
É comum saber da existência, mas não notar uma presença efetiva dos religiosos no espaço hospitalar, a qual se restringe a um coral e, no passado, a uma missa semanal. Os comentários são de que não há uma frequência (E2, E4), nem uma visibilidade, mas há uma demanda por parte dos pacientes (E2). Comenta-se que talvez seja por falta de tempo dos religiosos (E4, E5) ou por falta de recursos, de pessoal (E5). Se solicitados, eles comparecem.

Alguns pacientes têm uma vaga ideia do serviço religioso. De modo similar aos psiquiatras e enfermeiros, já ouviram falar (P4), as informações que normalmente se tem são sobre a capela, a missa (P6, P17, P5), um coral que aparece às vezes (P1, P6, P7, P14, P15, P16), um padre que fazia visitas, mas que não apareceu mais (P8). Outros pacientes não conhecem e nunca receberam nenhuma visita (P5, P7, P9, P10, P12, P13, P14, P15, P16, P17). Entretanto, como relata um enfermeiro, quando havia alguma atividade religiosa, os pacientes não se envolviam, não queriam participar, conversar (E7).

A explicação das autoridades religiosas para a tímida participação (no IPQ), por um lado, é a de que a missa era a forma de contato, depois que acabou também se perdeu essa comunicação (AR1). Por outro lado, mesmo este trabalho de apenas ofertar a missa era estranho, pois não propiciava o estabelecimento de vínculo com o paciente, já que o movimento era somente de celebrar a missa e ir embora (AR1). Há uma somatória de fatores no que diz respeito à interrupção dessa atividade no $I P Q$, uma delas é a falta de tempo, associada a ela existe o fato de não haver um grupo de pessoas realmente apto a fazer um contato inicial, no sentido de "preparar o terreno para que a missa seja celebrada" (AR1), para que não seja uma oferta de missa simplesmente.

\subsubsection{Atuação: casual e seletiva}

A realidade de atendimento religioso atual apresentada pelas autoridades, principalmente no caso da psiquiatria, é de presença em casos de emergências e chamados (AR1) e de atuação de alguns corais (AR3). É feita alusão, pelos 
profissionais de saúde, à época em que se celebrava missa semanal (M23, E9) e faz-se referência a uma "equipe de irmãos leigos" (M23) que assessoram o padre.

O argumento para a atuação irrisória é a falta de tempo - relacionada a uma demanda grandiosa, que é o HCFMUSP, para um pequeno número de profissionais (AR1) - e a questão dos horários rígidos (medicação, atividades terapêuticas, visita familiar) dos pacientes do IPQ, mediante os quais fica difícil adequar os horários dos padres, pastores, voluntários: "Os horários dos pacientes são muito complicados" (AR1). Além do mais, a psiquiatria é assunto para poucos. A entrada liberada é para padres e pastores ou para alguns voluntários (raros) a pedido do paciente: "Eu já visitei lá [IPQ]. Nós visitamos quando o pessoal pede. Não é uma visita como eu faço aqui [Instituto Central] (VR3)". Como afirma um entrevistado quanto ao fato de não haver participação dos voluntários no IPQ: "Isso é assunto do capelão. Voluntários, mesmo, eu não sei se tem alguém que vá lá. (VR4)”.

\subsubsection{Proposta: objetivos e como agir ${ }^{318}$}

A proposta primordial do serviço religioso é atingir os seguintes objetivos junto ao paciente: ajudar e confortar (VR1), escutar (VR6), respeitar as diferenças (VR13). Isso é o que as autoridades religiosas normalmente pregam e o que todos os voluntários respondem quando inquiridos. Algumas estratégias são utilizadas para a realização do atendimento religioso ${ }^{319}$ : aproximar-se de uma forma alegre (VR1, VR9, VR13); se o paciente é brincalhão, entrar com uma brincadeira para que ele aceite a presença (VR9, VR13); fazer a apresentação (VR1, VR4, VR6, VR13, AR1); mais ouvir do que falar (VR1, VR4, VR6); avaliar o momento: às vezes apenas entregar um folheto, às vezes ouvir o desabafo do paciente, outras vezes convidar para o culto (VR2); acalmar o paciente com palavras brandas (VR2); normalmente não perguntar a religião ${ }^{320}$, entender o paciente nas suas diferentes fases da doença

\footnotetext{
${ }^{318}$ Religiosos (6 racionalizados e 10 "magicizados") falam sobre a questão.

319 Importante lembrar que algumas destas posturas refletem um tipo de posicionamento no campo religioso: "magicizado" ou racionalizado, sobre o que já se discorreu.

320 A orientação do serviço religioso é para que não se pergunte qual a religião do paciente, mas alguns voluntários o fazem. Existe um impasse: uns acham que se deve perguntar qual a religião do paciente e outros acreditam que não.
} 
(VR4); estar presente para o paciente desabafar (VR4, VR9); não prometer cura/não prometer nada de Deus (VR7, VR13); pegar o nome para oração (VR8); convidar para a missa (VR8, VR9, VR11); respeitar as recusas, as diferenças (VR10, VR13); ser observador (VR13); levar conforto (AR2).

Uma das principais atitudes dentro do ambiente hospitalar deve ser 0 respeito, o qual precisa ser colocado em prática não somente em relação ao paciente, mas também no tocante ao trabalho do médico - se este se encontra junto ao paciente não se deve atrapalhar (VR2, VR5, VR10, VR13) - e no que concerne à autoridade do enfermeiro (VR3, VR4, VR12). O respeito em relação ao paciente deve acontecer: quando este se recusa a ouvir (VR2, VR4); não fazendo propaganda de igreja (VR3, VR4); não prometendo cura (VR2, VR4, VR13); não impondo, respeitando a vontade do paciente (VR7, VR10, VR13); pedindo licença para entrar (VR6). As orientações passadas aos voluntários são: respeitar o espaço do paciente (VR6); "entrar pela porta que o paciente abrir" (AR1); não opinar sobre o tratamento (AR1, VR10, VR11); entender que a ajuda é sempre para o paciente independente da religião que ele tenha (AR1); observar (AR1); procurar ser uma pessoa consoladora/terapêutica sem necessariamente falar de Deus (AR3); não falar de cura da parte de Deus (AR3); ter escuta, disponibilidade para ouvir (AR3).

Por fim, para desempenhar um bom papel enquanto religioso é necessário ser astuto, estar atento aos sinais que o paciente emite. O trabalho de assistência religiosa hospitalar é para o sujeito hábil e observador. Indispensável, portanto, saber o momento de falar, o que falar, observar o quarto (que tipo de livro está lendo), os adornos (o que traz amarrado no pescoço ou na mão), as preferências, o discurso do paciente (se reza, se ora, se fala de encarnação, vidas passadas), os sinais (virar as costas, fechar o olho, ficar muito calado, que podem indicar contrariedade com a presença do religioso). A partir disso, engatar uma interação que possa ser satisfatória: "Você tem que estar muito atento para perceber o que a pessoa está querendo te dizer através dos sinais (AR3). É necessário, portanto, "observar o ambiente porque isso dá informações importantes" (AR1). Dessa forma, os religiosos jamais precisarão perguntar diretamente ao paciente qual a sua religião, e ainda assim saberão com quem estão falando (AR1). VR6 durante as suas visitas, por exemplo, observa se "na cabeceira da cama tem uma Bíblia", VR13 
sabe que os evangélicos são mais missionários e que, por isso, é possível sempre notar que eles têm uma Bíblia ao lado.

Ao se considerar o predomínio do modelo psiquiátrico identificado como organicista, restrito à patologia do corpo físico, a importância no atendimento religioso residiria na valorização que ele concede ao corpo subjetivo (afetos, sentimentos, emoções).

O discurso explicativo e orientador de ações para a assistência da psiquiatria clássica pode ficar fragmentado diante do sujeito que se percebe com alterações no corpo físico, mas também está ciente que suas dores são de outra ordem. Assim, poderá haver um certo alento diante de instituições outras que demarcam suas atividades no âmbito da subjetividade, de um sentir que vai além das percepções físicas. (MACHADO, 2001, p. 76).

No entanto, mesmo havendo aqueles psiquiatras e enfermeiros, denominados bi-posicionados e neutros/ambíguos, que conseguem enxergar uma importância no trabalho religioso junto ao paciente, o que irá predominar de um modo geral, como atestam os próprios depoentes desta pesquisa, é o modelo voltado para o corpo biológico em oposição ao "corpo cultural".

\subsubsection{Formação: capacitação e treinamento ${ }^{321}$}

Quem quer exercer a função de assistente/voluntário religioso deve: participar ativamente de alguma comunidade/pastoral religiosa (no caso do serviço religioso católico); fazer pelo menos algum curso de formação (AR1); ter perseverança (AR1, VR2). A capacitação dos religiosos é sempre colocada como uma questão importante para reflexão, o que é feito tanto pelos médicos e enfermeiros quanto pelas próprias autoridades religiosas. Para estas últimas, o religioso capacitado deve ter sempre em mente que o paciente necessita de atendimento primeiramente no "âmbito físico" (AR3), para depois ser atendido no que concerne ao aspecto espiritual. Ou seja, deve estar muito bem claro que, frente ao tratamento médico, "a questão espiritual/religiosa torna-se, ainda que

\footnotetext{
${ }^{321}$ Religiosos (6 racionalizados e 10 "magicizados") discorrem sobre a questão.
} 
fundamental/substantiva, um pouco acessória" (AR3). Além disso, os religiosos são orientados a não entrar em questões do tratamento médico com o paciente. Assim, como é possível perceber claramente, há um empenho em destacar e fazer vigorar o valor prioritário dos procedimentos psiquiátricos.

As recomendações das autoridades religiosas aos voluntários parecem ser enfáticas: o tratamento médico em primeiro lugar, o cuidado com o que se fala, não dar opinião sobre o que fazer em relação ao tratamento (AR1), a importância do trabalho de escuta, o não proselitismo, entre outras coisas. O objetivo do curso de formação é o de instruir sobre a maneira de se aproximar dos pacientes (AR2) e como lidar com eles (VR1), mostrando ao voluntário que não se deve emitir qualquer tipo de julgamento junto ao paciente: "É muito bom o curso porque fala muito de como lidar com os doentes" (VR1). Os católicos e os evangélicos, segundo informações das autoridades e dos próprios voluntários, recebem orientação semanalmente, antes do horário de visita.

Entretanto, os objetivos do curso de formação - que são os propósitos do atendimento religioso difundidos pelas autoridades religiosas - não são os mesmos assumidos pelos voluntários religiosos. Aqueles com mentalidade racionalizada entendem bem as regras do atendimento, os "magicizados" assimilam algumas regras, mas passam por cima de outras. Neste último caso, pode-se citar como exemplo a utilização do discurso que atribui ao demônio a responsabilidade pelas doenças (VR2) e a crença de se estar lidando, no caso dos transtornos psiquiátricos, com "doença espiritual" (VR2): "Nem todas as pessoas que têm esse tipo de problema têm uma doença, vamos dizer, carnalmente; às vezes é espiritualmente. Porque a gente sabe que tem aquelas doenças que o inimigo pôs e são essas que não têm diagnósticos, [...] é uma doença espiritual" (VR2).

Ao mesmo tempo em que se vê ser colocado em prática semelhante discurso, é possível visualizar, em contraposição, uma crítica das autoridades religiosas que execram esse tipo de atuação. Trata-se de depoimentos coletados de religiosos de um mesmo serviço religioso e numa mesma época, mas claramente com atitudes em desacordo. Muito provavelmente elas aconteçam paralelamente. Os leigos atuam contrariamente ao postulado pelos especialistas. Esses acontecimentos são sintomáticos de um modelo de assistência religiosa que não 
aglutina verdadeiramente os participantes em torno dos especialistas (padre, pastor) - figuras emblemáticas do serviço religioso - e de sua orientação secularizada.

Como lembrado por Bourdieu, os especialistas ao moralizarem o saber religioso o tomam como seu e fecham-se ao restante dos sujeitos que compõem o campo. Ocorre com isso uma monopolização do saber religioso e, portanto, dos bens de salvação por uma camada de especialistas que se tornam os detentores da produção e reprodução do conhecimento religioso. A outra parcela que constitui o campo religioso (os leigos) é desapropriada desse conhecimento, e aceitam isso por não terem consciência do fato. Esses últimos ocupariam uma posição inferior na divisão do trabalho religioso por não possuírem um capital religioso significativo.

A necessidade de uma reatualização, uma reciclagem é sentida por parte de alguns voluntários que percebem a defasagem de formação de colegas que agem de maneira contrária ao que foi ensinado (VR13). Por exemplo, há os que veem no atendimento religioso uma maneira de realizar o desejo de cuidar fisicamente dos doentes (VR8): "[...] Pra mim, que eu gosto muito de medicina. Eu gosto demais. Eu leio livros. Eu gosto de tratar de doentes. Muita coisa eu queria saber" (VR8).

A questão passa não somente pela falta de formação ${ }^{322}$, mas também pelo fato de - quando ela existe - como é absorvida, enxergada pelo religioso (VR13). Às vezes, numa postura de intolerância religiosa - "já aconteceu aqui, da pessoa dizer que é evangélico ou é uma coisa, [o voluntário] virar e não conversar" (VR13) evidencia-se a premência de reciclagem (VR13). Esta também é urgente para aqueles que consideram que o imprescindível para o voluntário é ter conhecimento das orações (VR11), ter a devida informação sobre a doutrina religiosa da qual é portador. Ou seja, não se trata apenas de questão de falta de formação, mas também de não assimilação e aceitação do que foi orientado (VR13) e, assim, o que acaba acontecendo é que: "Coisas faz que não pode ser feito" [...] (VR13). Por

\footnotetext{
${ }^{322}$ Alguns confessam não ter tido ainda a oportunidade de fazer o curso de formação (VR12, VR6), mas participam de uma reunião semanal de orientação para o trabalho, ou até mesmo, acompanham outros agentes no trabalho até que estejam familiarizados e seguros. Entretanto, como afirma VR6: "[...] no fundo você acaba sendo você mesma. Quer dizer: eu visitei todos, mas eu tenho o meu jeito (VR6)". Há também os casos em que o voluntário inicia o trabalho - ainda que não possua o curso de capacitação - mediante o contato com pessoas que já fazem parte da equipe. Nesse tipo de seleção, eles são observados pelos responsáveis no sentido de serem avaliados em relação à permanência (VR2), como é o caso citado por alguns evangélicos: "Se a pessoa tem uma pessoa que já conhece, já está aqui... por exemplo: o que muitas pessoas fazem é o que fizeram comigo, trazem, [o responsável pelo serviço religioso] vê a permanência porque tem pessoas tipo fogo de palha" (VR2).
} 
exemplo, eles são orientados não somente em relação a não prometer cura, milagres como também a não fornecer comida, água para os pacientes. Porém, muitos ficam sensibilizados e acabam contrariando as regras: "Nós somos proibidos até de estar mexendo, dando uma água para um paciente. Não pode se fazer nada. E tem muitos aqui que dão. Que vão auxiliar, que ficam com dó, mas não é certo" (VR13).

As autoridades religiosas afirmam que o objetivo não é fazer referência a este ou àquele credo junto ao paciente. Essa orientação é acatada por uns e desconsiderada por outros, que enxergam como condições sine quibus non da função de voluntário: "dar uma de psicólogo" (sinônimo de ouvir o desabafo do paciente) e "falar de Jesus". Estas são vistas como requisitos para que sua presença faça sentido no hospital (VR2) - "vai surgindo assunto, entrando na palavra de Deus porque esse é o nosso objetivo: falar de Jesus para eles; se abre oportunidade, a gente entra com a palavra do evangelho" (VR2). Os que acatam as orientações assimilaram que a visita realizada não tem como objetivo "falar de Deus" ou "evangelizar/catequizar" (VR9), ao contrário a finalidade é "ser solidário com o doente", "estar mais aberto para ouvir do que falar" (VR9).

Mesmo ocorrendo esses desencontros entre voluntários e autoridades, para fazer parte da equipe de assistência religiosa existem critérios. Ajuda o fato de haver feito o curso de agente de pastoral da saúde $(\mathrm{VR} 10)^{323}$, no caso dos católicos por exemplo. Para ter acesso a esse curso é necessário pertencer a uma comunidade religiosa (no sentido de ter atuação na Igreja Católica) e ser indicado pelo padre dessa comunidade, o qual precisa reconhecer se a pessoa tem um bom histórico pessoal, familiar - se tem condições psicológicas, se não é drogado (VR10). Dessa forma, o serviço religioso católico parece estar relacionado, em grande medida, ao trabalho da pastoral da saúde, visto que os voluntários normalmente a ele se referem (VR6, VR7, VR9, VR10, VR13). Entretanto, a concepção de pastoral da saúde e a de capelania hospitalar são avaliadas como distintas, já que a primeira volta-se para aspectos do catolicismo e a segunda para aspectos mais amplos, relacionados a uma espiritualidade que não necessariamente está vinculada a uma religião: "Pastoral da saúde tem uma visão enviesada do catolicismo que vem

${ }^{323}$ Muitos entrevistados faziam referência à pastoral da saúde, dando a entender estarem ligados a ela de alguma forma. Mesmo em relação ao curso da referida pastoral não é qualquer pessoa que pode fazer, existem critérios (VR10). 
enfocando exclusivamente determinados aspectos daquela religião. [...] A capelania é uma coisa mais envolvendo a espiritualidade" (M13). Com isso, alerta-se para o aspecto tendencioso do serviço de assistência religiosa hospitalar, o qual não deveria estar vinculado a uma religião em especial.

Dentre a diversidade de voluntários e a multiplicidade de atitudes com relação ao trabalho de assistência religiosa encontram-se aqueles que sabem de cor o que dita a cartilha da assistência religiosa. Estão conscientes, por exemplo, de que: não se deve fazer proselitismo, propaganda, pregar (VR3, VR4, VR6); não se deve prometer cura (VR7); é necessário fazer os cursos (VR5); respeitar a vontade e o espaço do paciente (VR6); não opinar quanto ao tratamento do paciente (VR9, VR10, VR11). Entretanto, é necessário frisar que o fato de saber as regras não garante o seu cumprimento. Nem todos "andam na linha", ou seja, não são todos que acatam as orientações dos especialistas ${ }^{324}$ (os "magicizados", por exemplo, obedecem e desobecem as regras ao mesmo tempo). De um lado, há os que se garantem: "Eu posso responder por mim e a orientação que nós temos é sempre respeitar o espaço do paciente" (VR6). De outro lado, há os que estão convencidos de que sua atuação está de acordo com as regras, mas que apresentam contradições mediante seus relatos - "[A gente fala]: 'Deus vai fazer o que há de melhor pra sua vida'. A gente nunca pode falar para o doente que ele vai ser curado. Ninguém sabe. Tem doença que não tem cura. 'Pode ter certeza que Ele vai fazer o que há de melhor na sua vida'” (VR7).

As autoridades religiosas têm conhecimento da "teimosia" dos leigos, considerados "cabeças duras" (AR1), no sentido de que são orientados quanto ao procedimento correto e não agem em conformidade com ele: confundem os seus problemas pessoais ${ }^{325}$ com as dificuldades dos pacientes; acham que "tudo que fala de Deus é bom"326 (AR1). Além do que, contrariando tanto o posicionamento dos psiquiatras quanto das autoridades religiosas, que consideram importante uma

\footnotetext{
${ }^{324}$ Trata-se desta questão no Capítulo 4 da segunda parte.

${ }^{325}$ AR1 percebeu numa ocasião de reunião, na qual a proposta era refletir sobre um texto, que os voluntários se ativeram a falar de problemas pessoais e familiares. O depoente admoestou-os afirmando: "Eu estou preocupado porque, se vocês saem daqui e, ao chegar no quarto, ficam falando dos problemas da família de vocês, coitado dos pacientes! Eu estou assustado com o que eu estou ouvindo aqui" (AR1).

${ }^{326}$ Esse argumento pode ser usado, na verdade, como subterfúgio para não se fazer os cursos de preparação.
} 
formação para além da boa vontade, alguns voluntários acreditam que a boa vontade é suficiente para se iniciar um trabalho ${ }^{327}$.

[...] O pessoal fala: "Você tem boa vontade está bom. Eu deixo que Deus fala". Que Deus fala? Se você não se prepara... É uma coisa que eu repito sempre: você tem um bom coração, é caridoso, você acredita em Deus, tem fé, você pode fazer uma cirurgia? Eu falo: "Você deixaria o papa fazer uma cirurgia em você porque ele é papa? Eu não deixaria". Agora nós estamos exigindo que todos façam [o curso] porque o duro do religioso é aquela bendita coisa: "Jesus falou que não precisa se preocupar com o que você vai falar, o Espírito Santo vai pôr na sua boca o que você vai falar". Bonito! Vai lá nos EUA sem aprender inglês vê se os outros conseguem entender o que você fala. É aquele negócio: "tudo que fala de Deus é bom". Nem toda boa fé é uma fé boa. (AR1).

O curso preparatório, na percepção dos voluntários, poderia ajudar nos sentidos de: ser uma "fonte" de fortalecimento espiritual para poder transmitir alguma coisa ao doente (VR6); ajudar a estar atualizado (VR7); ser um instrumento de avaliação das condições psicológicas e emocionais do voluntário religioso (VR10), pois não é "qualquer leigo" (VR10) que pode fazer esse tipo de trabalho.

A formação religiosa, entretanto, parece não dar conta da realidade com que se depara o voluntário, o qual se confronta com situação diferente, na qual há uma diversidade religiosa que não fora contabilizada - "É obrigatório [o curso], mas a realidade é diferente: não temos só católicos, tem evangélicos, tem espíritas, tem Testemunha de Jeová. Nós atendemos todos". (VR5). Situações adversas podem surgir ao longo do trabalho de assistência religiosa, como relata VR7, que se deparou com uma pessoa de outra religião e não soube qual a atitude a ser tomada: "A semana passada tinha um budista. Como você vai falar? 'Que o Buda te abençoe'!?" (VR7) ou como no caso relatado por VR13 - "eu pensei na hora e falei: 'Meu Deus, ele é Testemunha de Jeová, que oração eu vou fazer pra esse senhor?'” (VR13). Nesses momentos desponta o problema, criticado pelas autoridades, de acreditar que não é necessário preocupar-se porque "Deus fala" (AR1). É o que confirma VR13 quando diz: "Na hora parece que o Espírito Santo ilumina a cabeça da gente" (VR13).

\footnotetext{
${ }^{327}$ Parece que quanto menor o capital religioso, há mais chances de o discurso da "boa vontade" ser assumido. Ao contrário, a maior posse de capital religioso faz com que se valorizem as formações e os treinamentos.
} 
Ou seja, a formação religiosa por si só não é suficiente para a realização de um bom trabalho de assistência religiosa. É preciso disponibilizar - já que a realidade brasileira é de pluralidade religiosa - uma diversidade de opções que correspondam às necessidades de todos os pacientes, e não somente de uma maioria cristã, que acaba sendo a única favorecida.

\title{
6.1.5 Pontos de vista: o olhar sobre a doença psiquiátrica ${ }^{328}$
}

\begin{abstract}
Suponho o espirito humano uma vasta concha; o meu fim [...] é ver se posso extrair a pérola, que é a razão; por outros termos, demarquemos definitivamente os limites da razão e da loucura. A razão é o perfeito equilíbrio de todas as faculdades; fora daí insânia; insânia e só insânia. [...] Com a definição atual que é a de todos os tempos [...] a loucura e a razão estão perfeitamente delimitadas. Sabe-se onde uma acaba e onde a outra começa. Para que transpor a cerca? (O Alienista, Machado de Assis).
\end{abstract}

Aproveitando o ensejo de que não é "qualquer leigo" que pode realizar um trabalho nos hospitais junto aos enfermos, procurar-se-á verificar em que medida esta afirmação corresponde à realidade. Assim, a ideia é abordar neste momento a maneira como os religiosos referem-se à doença mental: quais as expressões utilizados e se existe preconceito ou não. Como eles traduzem a loucura e qual o papel que lhe atribuem.

A doença psiquiátrica, assim como as doenças físicas, pode ser vista como doença espiritual (VR13) e, desse modo, é encarada como sendo de difícil diagnóstico. Por sua vez, os pacientes do setor psiquiátrico podem ser vistos como pessoas não conscientes, de humor instável (VR2, VR13) com comportamento imprevisível, "malucos" (VR3), "facilmente sugestionáveis" (AR3), agressivos (VR12), pessoas que "sempre têm um lado na parte espiritual" (VR13), que podem variar de violentas a super calmas. A percepção sobre a doença psiquiátrica e o "doente

${ }^{328}$ Religiosos (4 racionalizados e 5 "magicizados") falam sobre a questão. 
mental" é caudatária da antiga perspectiva cartesiana do "penso, logo existo" que declaradamente cerra fileiras contra a desrazão. Semelhante ponto de vista não faz mais do que detratar a loucura fazendo com que se perceba a "doença psiquiátrica" como algo "terrível” (VR7), o “doente da cabeça 'parada”" (VR3).

A visão aqui é compartilhada não somente pelos religiosos "magicizados", evidenciando dessa forma que o posicionamento dos racionalizados - considerado adequado para o ambiente hospitalar - pode ser tendencioso. Como faz AR3 ao afirmar, por um lado, que "o hospital psiquiátrico é ímpar", dando a entender que nele as pessoas necessitam de um tratamento diferenciado. Por outro lado, é hesitante quando sugere que "os pacientes psiquiátricos são facilmente sugestionáveis; tem aquelas coisas deles, aqueles delírios de ver Deus" ou ainda ao vê-los como pessoas que "querem uma coisa imediatista, [que] se remetem a esse transcendentalismo e a gente precisa ter cuidado porque muitos acham que são espíritos, demônios". (AR3). A forma como os religiosos fazem referência aos pacientes psiquiátricos, quando inquiridos sobre um possível atendimento religioso a essa modalidade de paciente, é prova prima facie do desconhecimento e preconceito que possuem sobre os transtornos considerados psiquiátricos.

Não obstante tais percepções, alguns acreditam que com uma formação de assistência religiosa voltada para estes casos, com "aprofundamento do tipo de doença" (VR4) seja possível realizar um bom trabalho no setor psiquiátrico (VR6, VR9, VR12). As autoridades religiosas são mais pessimistas a esse respeito: não se consideram preparadas para este tipo de atendimento e acreditam que o voluntário muito menos estaria apto para tanto (AR1). Ainda que percebida como infausta a situação do "louco" pelos voluntários; estes, dentro de toda suposta sanidade que se autoatribuem, não são considerados preparados para atuar no setor psiquiátrico.

Eu acho que não teria uma formação própria para trabalhar .[...] Naquele momento de confusão... Eu falo por mim. Muito mais o voluntário que de repente ele começa a entender que aquilo é [inaudível]. Teve uma senhora, uma vez, evangélica que achou que aquilo era demônio, que não sei o que, e não é. [...] Me assusta um pouco porque eu vejo que as pessoas são muito limitadas. Então, o meu receio sempre foi não deixá-los [os pacientes] piores do que já estão. Posso estar errado, mas eu penso que nós não temos pessoas voluntárias preparadas para fazer esse tipo de trabalho. Eu penso que é melhor não fazer. (AR1). 
Assim, a grande questão a ser retomada aqui é a disparidade entre o saber do especialista religioso e a condição do leigo. Entre eles há um diferencial - que é possível perceber não apenas mediante as posturas, mas igualmente pela diferenciação que os próprios especialistas procuram fazer quando deixam subentendido que "uma coisa são os leigos, outra coisa bem diferente são os ministros religiosos" (AR1). Essa demarcação é realizada, provavelmente, com intuito de deixar bem evidente que há um saber secreto conferido a poucos e inacessível a muitos outros (leigos). Ou seja, fazendo uso da leitura bourdieusiana, tem-se a divisão entre os que possuem um capital elevado e os que estão destituídos desse mesmo capital. Todos, engrenados num mecanismo de luta por poder que faz parte do funcionamento do campo religioso.

\subsubsection{Convivência: relacionamento entre os agentes religiosos ${ }^{329}$}

O encontro entre o voluntariado católico e o voluntariado evangélico é pouco frequente, pois os dias de trabalho de ambos os grupos é diferente (VR1, VR3, VR6, VR9) ${ }^{330}$, o que faz com que se sugira algum tipo de confraternização com a finalidade de os dois lados encontrarem-se mais vezes. Parece haver respeito e tolerância em relação à presença e ao trabalho de cada um ("Não tenho nada contra eles" - VR1). Entretanto, comentários "desinteressados" acabam sendo feitos para fazer notar 1) quem está com a verdade: por exemplo, no modo como se interpreta a Bíblia (VR2), 2) quem invade o espaço do outro: as ocasiões em que voluntários de um serviço fazem seu trabalho no dia dos outros voluntários - "até eu falei para o padre Anísio porque calhou que eu fui levar a comunhão para a pessoa e elas estavam lá orando pra pessoa" (VR13). Entretanto, afirma-se que cada um tem um modo de ver que deve ser respeitado na sua particularidade (VR3). Entre os líderes acredita-se que não haja desavenças ${ }^{331}$, mas entre os voluntários pode haver e

\footnotetext{
${ }^{329}$ Religiosos (3 racionalizados e 5 "magicizados").

330 Os evangélicos reúnem-se nas segundas e quartas-feiras e os católicos nas terças e quintasfeiras.

${ }^{331}$ A despeito dessa afirmação, é conhecido o episódio de atrito no serviço religioso evangélico entre líderes da ala mais tradiconal e líderes da ala pentecostalizada, estes acusados de proselitismo, entre outras coisas.
} 
principalmente por parte dos evangélicos, pois se supõe que "quem deixou uma religião tem uma tendência maior em rejeitar a antiga" (AR1). Assim, é possível compreender quando a voluntária evangélica refere-se aos colegas católicos como pessoas que aprenderam "a palavra" (VR2) de forma errada; o que faz com que eles distorçam os ensinamentos bíblicos (VR2).

A afinidade entre eles é sugerida pelo fato de utilizarem o mesmo espaço físico (a capela) ${ }^{332}$, de indicarem a celebração concorrente ao paciente com o argumento de que "qualquer religião faz bem" (VR5). Afinal de contas, como se posiciona VR3, "a gente não pode achar que os outros só estão errados. Eles têm o modo de eles verem, nós temos o nosso". Algum atrito no interior de cada serviço religioso pode acontecer no sentido de as autoridades religiosas "darem uma puxada de orelha" (VR2) ao perceberem comportamentos inadequados - "às vezes tem uma briguinha com o padre, mas é por conta da religião porque eu acredito em reencarnação, ele não acredita" (VR5). Entre os voluntários de um mesmo serviço a convivência aparece como sendo tranquila, pois mesmo havendo membros pertencentes a denominações religiosas distintas (no caso do protestantismo: Presbiteriana, Batista, Assembleia, etc.) a relação é boa, não importando tais diferenças (VR2).

\subsubsection{Divisão do espaço: diversidade religiosa e conflito religioso ${ }^{333}$}

É necessário revelar aqui como é realizado o diálogo entre as religiões dentro do IPQ, que espaço é dado aos diferentes credos e como ele é ocupado. Quando se fala em atendimento religioso, algumas questões afloram automaticamente. As principais que aparecem nas falas dizem respeito à diversidade religiosa e ao conflito religioso no hospital. Uma demanda religiosa pede uma diversidade de ofertas religiosas. Entretanto, o problema já começa com a falta de representatividade do Comitê de Assistência Religiosa (CARE), o conflito

332 Os evangélicos usam a capela, mas não deixam de desqualificar a atitude católica de venerar santos, o que traz à tona discussões antigas. Entretanto, chega-se a um acordo diplomático como informa VR4: "Aqui tem um monte de imagens. Quando eles começam a falar de imagens a gente procura alguns textos bíblicos que possam exemplificar que eles possam aceitar".

${ }^{333}$ Religiosos (3 racionalizados e 5 "magicizados") abordam a questão. 
religioso torna-se patente a partir do momento em que religiões não cristãs vislumbram a possibilidade de fazer parte do serviço religioso oficializado, onde as religiões cristãs (que predominam no espaço hospitalar) estabeleceram um modus operandi (uma posição sacerdotal central) para que seu domínio não fosse desestabilizado.

É uma questão de natureza constitucional: qualquer instituição de saúde no Brasil é obrigada a fazer com que o ministro religioso daquele paciente possa assistí-lo. Obrigado é assim: se o paciente quer aquele ministro que o assiste paroquialmente, ou seja, que pertence à comunidade específica dele lá fora, então o hospital é obrigado a chamar esse ministro e dar todas as condições de assistência ao paciente que o chamou/pediu. Aqui no hospital isso se faz através de nós. [...] Nós já tivemos, aqui, rabinos que trabalharam conosco e temos aqueles que são espíritas que tem trabalhado, mas o cargo em si, dentro do CARE, que é a Coordenadoria Administrativa do Serviço Religioso está realmente vago. O critério que a gente adota aqui é no sentido de admitir as duas religiões mais predominantes no Brasil, que são a católica e a protestante. E a demanda de assistência aqui muito maior se dá dentro dessas duas correntes cristãs. Então se mantém essas duas religiões. Agora, esse cargo está realmente, digamos assim, sem função. Mas se você ler o texto, diz assim: "se for necessário a admissão de um outro". Não teria dificuldade de admitir. Mas só que eles [os espíritas], como não têm uma ordem hierárquica, fica difícil a gente, até mesmo, admitir porque a gente não sabe a quem se reportar. (AR3).

Assim como no caso do profeta, do feiticeiro, do sacerdote, o que existe atualmente entre os agentes religiosos de denominações diversas não é uma fronteira administrativa, é sim uma fronteira simbólica, a qual pode, por vezes, ser colocada em discussão no interior da morfologia de determinado grupo religioso. Aqui talvez essa fronteira (de concorrência) seja melhor visualizada não diretamente com o confrontamento entre as religiões, mas mediante atitudes como: a tentativa da introdução dos espíritas no serviço religioso; a atuação "magicizada" num modelo que se pretende racionalizado e "cientificizado"; as querelas em torno dos Testemunhas de Jeová.

O Testemunha de Jeová (TJ) é um exemplo paradigmático, utilizado tanto por religiosos quanto por psiquiatras, para identificar a possibilidade do conflito. Se na visão dos últimos trata-se de um tipo de religião radical que impede o seu trabalho de um modo geral, na perspectiva dos religiosos trata-se de concorrentes de difícil relacionamento reconhecidos mais como aqueles que se veem como 
profetas que vêm para predizer um tipo de verdade, sendo referidos ao modelo seita $^{334}$. Apesar de o modelo recorrente de inquietação apresentado pelos psiquiatras sejam os $\mathrm{TJ}$, o conflito pode ocorrer com relação a religiões como as neopentecostais, a espírita. Identificadas como: indústria de ganhar dinheiro - as neopentecostais (VR1); radicais - os Testemunhas de Jeová e algumas neopentecostais (VR5, VR3, VR1, VR13); os que "atravessam a ala da fé" - os espíritas (VR8). Todas essas religiões desempenham um papel particular que movimenta o campo religioso em torno da concorrência.

Por vezes, alardeia-se: “A gente é democrático!” (VR10). Entretanto, o argumento recorrente de que "Deus é um só"335 (aprendido de cor) reaparece para esconder fissuras e até mesmo para passar por cima da realidade da diversidade religiosa e do necessário espaço para as outras religiões. Mediante tal argumento torna-se possível colocar crenças diversas (aqui, no caso, restritas ao campo protestante) sob um mesmo teto. Nesse "ecumenismo protestante", segundo Negrão (2001, p. 28), “há apenas uma crença, portanto, que é fundamental: no Deus único e no qual se deve acreditar e confiar [...] Neste sentido, pouco importa pertencer a um outro grupo, ou ainda a nenhum deles, pois são vistos como meios alternativos de se chegar a Deus [...]". Como já comentado em outro momento, o contexto de pluralidade religiosa proporciona um certo ecumenismo religioso.

Considerando a diversidade religiosa brasileira e a predominância das práticas cristãs na assistência religiosa hospitalar, acredita-se que a democracia darse-ia não pelo fato de - como propala o discurso religioso dominante - ser permitido receber religiosos de denominações não cristãs a pedido do paciente; mas sim, pelo fim do favorecimento proporcionado - sinônimo de mais regalias e espaço - aos grupos cristãos em detrimento dos restantes.

\footnotetext{
${ }^{334}$ Troeltsch (1987) foi o grande divulgador dos conceitos igreja/seita. No que diz respeito à aplicação desses conceitos ao Brasil, Souza (1969, p. 18, aspas da autora), na obra intitulada Experiência da salvação, realizou um trabalho pioneiro sobre os pentecostais em São Paulo onde ela usa a tipologia igreja/seita como instrumento de análise da realidade. Entretanto, a utilização desses conceitos pela autora não coincide com a maneira até então empregada pela sociologia da religião, para a qual "os grupos pentecostais são vistos como sectários, em confronto com as organizações mais institucionalizadas, que representam a modalidade 'igreja". Considera-se aqui, porém, que a linguagem classificatória igreja/seita parece não se adequar totalmente ao contexto brasileiro, onde todas as religiões organizam-se institucionalmente. Não havendo, portanto, uma divisão rígida, fala-se em novos movimentos religiosos.

${ }^{335}$ A mudança no interior do campo protestante, muito recorrente, ampara-se, como demonstram alguns estudos (FERNANDES, 1998; NEGRÃO, 2001; ASSUNÇÃO, 2004) no argumento de que "Deus é um só".
} 


\subsubsection{Práticas: contradição 336}

Dentro do contexto de assistência religiosa, alguns relatos revelam um modo de pensar oposto às expectativas do serviço religioso, o qual prega, por exemplo, que a ajuda não é para si próprio, ao contrário, "é sempre para o outro" (AR1). Mediante os discursos dos voluntários, foi possível constatar uma mentalidade que encara o trabalho religioso no hospital enquanto terapia para o próprio religioso e enquanto chamado de Deus. No primeiro caso, porque é o voluntário que: "recebe a caridade" e que por isso "se sente bem" (VR13); afasta de si a solidão e recebe atenção e carinho (VR1); consegue manter-se em constante alegria (VR3). No segundo, no sentido de: não ser necessário conhecer, pois quem é chamado por Deus já possui uma preparação que lhe é concedida pelo poder divino (VR2); ter-se um dom especial (VR7); a ajuda ao paciente ser uma forma de contemplar a Deus (VR4), de conversar com Deus (VR9). Por seu turno, as autoridades religiosas fazem severas críticas, pois essa mentalidade vem associada a não perseverança ao trabalho - "está cheio de gente que quer começar, se entusiasma: 'encontrei o Salvador', mas depois... porque o novo é legal, né?" (AR1).

Assim, o atendimento religioso tem uma meta diversa daquela que é ajudar ao outro; em oposição, passa a ser uma forma de autorrealização, de se completar, de estar em canal direto com Deus. Os benefícios são, nesse caso, totalmente voltados para o bem-estar do próprio religioso e não do paciente. A intenção não é salvar ou recuperar o outro, mas a si mesmo através dessa proposta de trabalho. Uma crítica a esse tipo de manifestação é feita por aqueles que são a autoridade religiosa lá dentro e que veem em semelhante postura uma falta de engajamento com a verdadeira proposta do serviço religioso - "O mais importante é perceber que a ajuda é sempre para o outro, não pra mim. Então, o outro é que deve dizer no que eu posso ajudar" (AR1). Dessa feita, mais uma vez coloca-se a questão do desencontro entre a linguagem falada pelas autoridades religiosas e a linguagem ouvida e assumida pelos leigos/voluntários.

No trabalho realizado pelos religiosos supracitados ocorrem também outras situações que contradizem as orientações dadas pelas autoridades religiosas no

\footnotetext{
${ }^{336}$ Religiosos (5 racionalizados e 8 "magicizados") discorrem sobre a questão.
} 
curso de formação. O contrassenso reside nas seguintes práticas: 1) Pegar nomes para colocar para oração ${ }^{337}$ (VR3, VR13, VR7), 2) Fazer oração/falar da "palavra de Deus"/evangelizar (VR3, VR12, VR2, VR7, VR10), 3) Convidar para missa/culto (VR1, VR9, VR11, VR10, VR2), 4) Entregar folhetos (VR3, VR12), 5) Perguntar qual a religião do paciente $(\mathrm{VR} 7, \mathrm{VR} 10)^{338}$, 6) Fazer benzimento (VR10). Embora em alguns trechos tenha sido possível perceber nas falas dos especialistas a referência positiva à oração, o comportamento dos não especialistas em relação a isso toma uma proporção maior ao colocarem no âmbito do "indispensável" procedimentos que deveriam ser apenas consequência de algo mais urgente: ouvir o paciente.

[...] A gente faz uma oração pra ele e depois a gente dá uns panfletos para ele, tudo versículo bíblico de fortalecimento. Se o paciente mesmo está meio sedado a gente lê para ele porque de alguma forma ele vai assimilar. [...] A gente fala que é para confiar no Senhor, que Deus jamais desamparará seus filhos [...] $E$ as enfermeiras padrões, que são responsáveis: a gente os evangeliza, dá livrinhos. (VR12).

Tem alguns que não têm condições de ir porque está no soro, está em repouso ou está esperando o médico e às vezes, se abre oportunidade, a gente entra com a palavra do evangelho, que esse é o nosso objetivo [...]. (VR2).

[Eu falo]: "Como nós temos a missa hoje, se vocês permitem que a gente coloque o nome de vocês na oração". Muita gente não quer. Muitas religiões não aceitam [...] Geralmente os católicos querem que ponha o nome na oração. Você não vê que, nas igrejas às vezes os que são devotos de algum santo sempre põe os bilhetinhos e leva para o santo? $(\mathrm{VR} 13)^{339}$.

Cada um tem uma cruz pra carregar. Então, o paciente está carregando uma cruz? Está. Só que a gente não pode carregar para ele, mas a gente pode dar conforto com palavras e aliviar o peso. Se ele quiser uma oração, um benzimento, uma eucaristia... (VR10).

Todas essas atitudes revelam a preponderância de um caráter "magicizado" em detrimento do racionalizado defendido pelas autoridades religiosas. $\mathrm{O}$ caráter

\footnotetext{
${ }^{337}$ Voluntário católico faz referência ao que ele denomina "missa pela saúde". Esta, ao que tudo indica, acontece em um dia específico. Importante notar nesse caso a semelhança dos católicos com os neopentecostais, os quais constituíram essa prática - cultos específicos (culto para a saúde, culto para a prosperidade financeira, etc) em dias também específicos - antes mesmo que os católicos.

${ }_{338}$ Segundo orientação das autoridades religiosas, não é recomendável perguntar a religião. A ideia é observar o quarto, os adornos para, se for necessário, saber se a pessoa tem alguma religião/religiosidade.

339 Interessante notar que esse informante situa-se neste estudo no polo racionalizado, requerido pela proposta religiosa hospitalar.
} 
racionalizado distancia-se de qualquer forma de proselitismo e é totalmente contrário a promessas de cura. De um lado, a panfletagem, o convite para a missa/culto, ainda que não sejam escancaradamente proselitistas, podem ser entendidos como investidas conversionistas. Assim como falar da palavra de Deus (seja lendo a Bíblia, seja fazendo testemunhos da bondade divina) é uma tentativa de evangelização. Por último, pegar nomes para oração remete a uma forma de empreendimento menos racionalizado: o milagre. Pegar o nome para oração é, de certa forma, prometer ao enfermo algum tipo de intervenção divina no processo de cura. Esses comportamentos distanciam-se em demasia da proposta de presença religiosa como alento e do religioso como aquele que muito ouve e pouco fala. Afastam-se ainda da ideia de não necessariamente falar de Deus, de igreja, de religião e, ao contrário, realizar um trabalho terapêutico, de integração do indivíduo. Por isso mesmo, AR1 acredita que o aspecto mais importante da religião é "no sentido comunitário", não reside particularmente nos ritos (confessar, comungar, rezar, ir à missa). Comunitário no sentido de o paciente saber que existe um grupo de pessoas, uma comunidade torcendo por ele e pela qual ele se sente mobilizado, entusiasmado a "continuar batalhando" (AR1).

Não necessariamente estar falando de Deus, em Bíblia. Não é isso. Você chegar perto de um doente e ficar descarregando Bíblia na cabeça dele, descarregando o seu discurso de Deus, de Cristo. Não é isso. É você ter o caráter de Deus, de Cristo em si, se deixar moldar por isso, por esse caráter e ser uma pessoa consoladora, fraterna, terapêutica junto ao doente. (AR3).

Uma realidade que salta aos olhos é a de que os agentes religiosos, em alguns momentos, repetem um discurso automático conforme o que lhes foi ensinado (para não serem repreendidos ou desligados do serviço) sem, entretanto, terem a real convicção; em outros momentos - e parece tratar-se da maioria das vezes - eles reproduzem um discurso mais conhecido seu e, por isso, mais genuíno. Este último discurso tem relação com o tipo de prática religiosa da qual participam fora do hospital: os evangélicos com o seu vocabulário e expressões específicas (composto de frases como "Deus tudo pode"340 (VR2), "Deus vai operar na vida" (VR2); os católicos com as suas ações, rituais e também com "pérolas" como "Deus

${ }^{340}$ De acordo com VR2 "o paciente que é religioso e tem fé, mesmo que ele saiba que está com uma doença grave e ele tem uma fé viva, aquilo não o abate. Não o abala porque ele sabe que está com Deus que tudo pode". 
manda a doença para cada um" (VR7). O habitus que trazem consigo possui essas propriedades. Mediante tais características particulares, o fato é que eles burlam as regras do serviço religioso, o qual não deveria teoricamente estar vinculado a não importa qual religião e seus mandamentos. Essa postura ambígua dos religiosos "magicizados" - ora se aproximam de características "mágicas", ora enfatizam aspectos racionais da religião - pode ser bem compreendida (afora a constituição de um habitus específico) ao considerar o que fala Weber sobre a fluidez que existe na separação entre categorias como magia e religião.

Para além de posicicionamentos como esses, o papel mais amplo da religião/religiosidade é o de ajudar na recuperação do paciente no sentido de proporcionar-Ihe esperança, ajudar a lidar melhor com a doença (AR2). Aí está a questão central que deve ser norteadora de um serviço religioso hospitalar que esteja dentro das normas de um hospital não confessional como o HCFMUSP. 
PARTE IV - CAMPO PSIQUIÁTRICO E CAMPO RELIGIOSO: RELAÇÕES 


\section{RELAÇÃO ENTRE CAMPO PSIQUIÁTRICO E CAMPO RELIGIOSO}

\subsection{LUGAR-COMUM E PONTOS DE CONFLUÊNCIA}

\subsubsection{Paciente, imaterialidade e exclusão ${ }^{341}$}

Se acontece algum tipo de relação entre psiquiatras e religiosos é em função dos pacientes. Ou seja, o paciente é o intermediário nessa relação, seja no que diz respeito ao conflito, seja em relação ao diálogo. Isso porque independentemente de ser adepto ou não desses dois domínios ${ }^{342}$, o paciente é o vértice para o qual convergem os investimentos tanto dos religiosos quanto dos psiquiatras.

Cada um dos dois domínios (psiquiátrico e religioso) percebe um ao outro direta ou indiretamente mediante os pedidos dos pacientes. Haverá uma retradução (como se verá nas páginas a seguir) dos possíveis pedidos realizados tanto no âmbito da psiquiatria quanto no âmbito da religião, visto que os profissionais encontram-se nesse "lugar" de reflexão (a partir do qual eles farão referência um ao outro).

Embora os objetivos e caminhos de cada qual pareçam distintos, há um ponto comum, um único propósito (E1) que os coloca em contato: o paciente e o seu sofrimento e juntamente com isso a cura (não importa se medicamentosa, psicológica, espiritual). Assim, os psiquiatras bi-posicionados e neutros, do seu lado, consideram que o bem-estar (M1, M20) do sujeito adoecido é o que, pelo menos teoricamente, os assemelham (médicos e religiosos), seja no sentido de curar alguma dor, algum incômodo (M6), seja no sentido de aliviar o sofrimento (M8,

\footnotetext{
341 Psiquiatras (1 mono-posicionado, 3 bi-posicionados, 13 neutros), enfermeiros (2 neutros) e religiosos (3 racionalizados) falam sobre a questão.

342 Pode-se levantar a seguinte indagação: a religião não seria atuante apenas no paciente fiel e a psiquiatria atuante apenas no paciente que procura tratamento voluntariamente? Faria sentido falar em lugar-comum para aqueles pacientes que não têm uma religiosidade e para os que não são adeptos do tratamento psiquiátrico, ou seja, aqueles para os quais os dois domínios de atuação são impostos? Considera-se que, a despeito de o paciente não ser fiel ou não receber o tratamento psiquiátrico voluntariamente, o contato não deixa de existir.
} 
$\mathrm{M} 20)^{343}$. Entretanto, o que se percebe é que, pensando em termos de colaborar com a melhora do paciente, há "uma baixíssima integração entre corpo clínico e os cuidadores do ponto de vista religioso" (M1). O que é visto como uma falha. M1 acredita que deva haver um trabalho em conjunto respeitando os limites de cada um e evitando a desconfiança mútua. O suporte duplo bem como o multidisciplinar pode ajudar o paciente (M18).

A fé é algo que, normalmente, habita em ambos os domínios: medicina e religião. Assim como nesta última, na medicina também ocorre a mobilização da fé, tanto no sentido do médico fazer com que o paciente acredite que vai melhorar quanto no sentido do profissional também acreditar nisso (M17). Há outra associação entre ambas - desta vez de caráter negativo do ponto de vista da psiquiatria - que é quanto ao fato de a psiquiatria/doença psiquiátrica vir "muitas vezes como um castigo de Deus" (M21). Essa ideia, constituída historicamente, é forte e permanece no imaginário popular que - por não haver no seu seio a divulgação do conhecimento médico - acaba por perceber, por exemplo, "uma crise epiléptica como uma possessão demoníaca" (M21).

Os religiosos, por seu turno, atribuem a semelhança dos dois domínios a questões como: fazer com que as pessoas sintam-se bem (AR1); buscar o bem do outro (AR2). Nos escritos bíblicos mesmo, acredita-se ser possível encontrar passagens que mostrem afinidades - no que concerne ao bem-estar dos homens entre o pensamento das escrituras e o pensamento médico.

Na Bíblia tem muita coisa a ver ali com medicina. Esses dias eu estava lendo em uma tradução um tema interessantíssimo. Hoje existe uma técnica, uma psicoterapia chamada terapia cognitiva comportamental [a qual] propõe que, para melhorar situações de depressão, de ansiedade, coisa e tal é ter cuidado com aquilo que se pensa. O pensamento é o fundamento de toda a desordem. Ou de todo o equilíbrio. E eu, lendo um dia desses na Bíblia no livro de provérbios, eu vi exatamente isso: cuidado com o que você pensa porque toda vida deriva do seu pensamento. Você entendeu a relação? Uma coisa que foi escrita sabe lá quando, há quantos mil anos, é exatamente o fundamento de uma técnica psicoterápica que

\footnotetext{
${ }^{343}$ No entanto, no caso da religião, o alívio do sofrimento acontece por intermédio do conforto, já na medicina acontece mediante a cura, o tratamento (M19), são posturas diferentes. Além disso, as diferencia o fato de o sujeito adoecido ter mais coragem de buscar a religião do que a medicina. Isso porque, acredita-se, "há menos medo na religião do que na medicina. As pessoas têm medo de ir pra um médico e de ouvir notícia ruim. Às vezes acaba se apegando na religião, de certa maneira. Deus vai curar. E se apegam nisso". (M6).
} 
se propõe nos dias de hoje! E outras coisas mais. Há especialistas nisso: de procurar na Bíblia fatos e coisas descritas que se relacionam à saúde. A questão mesmo da circuncisão nas crianças hebréias. Eu não sei exatamente como descrever, mas tinha a ver com uma doença que se estabeleceu nos judeuzinhos daquela época que até o oitavo dia tinha uma inflamação/infecção no pênis, na glande exatamente porque a glande não era exposta. O prepúcio cobria. Então, por uma medida higiênica... se supõe que Deus falou: "Façam isso e isso vai ser um sinal de comunhão entre mim e vocês," mas tinha também um caráter sanitário. Interessante! (AR3).

Além disso, pontos de encontro entre psiquiatras e religiosos podem se efetivar no sentido da imaterialidade relativa aos seus respectivos objetos, visto que nem as questões psíquicas nem as espirituais são palpáveis ${ }^{344}$ : "A doença psiquiátrica é uma coisa que a gente não vê" (E9). Desse modo, encontram-se no plano do indizível, do irracional. A semelhança é historicamente verificada ${ }^{345}$. O que não se vê é mais difícil de classificar, de traduzir. Segundo E9, é necessário ter fé, pois "analisamos imagens que [sic] não aparece nada. Um cérebro de um esquizofrênico e às vezes um cérebro de um normal, entre aspas, é igual" (E9).

Outro ponto de encontro diz respeito à exclusão, no sentido de que ambas ditam as regras do que é bom ou mau, certo ou errado, normal ou patológico: uma diz quem é louco, a outra diz quem é pecador: "O psiquiatra é o dono de uma verdade e o religioso é dono de uma outra verdade" (M24). As duas podem desempenhar o papel tanto de redentoras quanto de algozes. A consequência advinda dessa ambiguidade é a exclusão daqueles que estão fora das normas estabelecidas tanto por uma como por outra.

Eu acho que a psiquiatria é uma coisa bastante interessante. $A$ medicina psiquiátrica, de alguma maneira, vai agir nas ações do indivíduo também da mesma maneira como o religioso. Se você for parar para pensar na posição que o psiquiatra e o religioso estão na sociedade, eles podem entrar numa certa competição porque 0 psiquiatra diz o que é louco e o que não é, o que é certo e o que não é. Quem é esse cara que estudou seis anos e pode determinar se eu

\footnotetext{
${ }^{344}$ Há os que acreditam que as questões psicológicas, ao contrário das espirituais, são palpáveis (M12). Nesse ponto de vista, as primeiras podem ser capturadas de alguma forma mediante estudos e pesquisas cientificamente comprovadas, o que não é possível às segundas.

${ }^{345}$ M16 acredita que não é possível separar psiquiatria e religião: "Se for analisar do ponto de vista histórico, as doenças psiquiátricas durante séculos eram vistas como doenças da alma. A epilepsia era uma doença dos deuses. Que os deuses enviavam. Era uma doença divina. Historicamente as coisas andam juntas". (M16).
} 
estou certo ou se eu estou errado? Se eu estou errado, então eu sou louco, tenho que tomar remédio? [...] É o Alienista e tudo o mais. E o religioso tem uma posição parecida porque o religioso tem uma verdade, cada religioso tem a sua, pode ser mais eclético, menos eclético, mais aberto para outras verdades ou não, mas tem uma forma de agir. Tem uma forma certa de agir. Geralmente, em todas as religiões que eu conheço você tem uma maneira de agir que é a maneira considerada correta e se você fugir dessa maneira correta existem consequências. (M24).

Não obstante as possíveis semelhanças e diferenças, em determinados momentos ocorrem empreitadas de substituição (de uso exclusivo) de uma pela outra realizadas pelo próprio paciente. Essas ocasiões servem para elucidar o poder de decisão que o paciente tem em relação às possíveis ofertas. O paciente, provavelmente, não está preocupado - como é o caso dos psiquiatras e religiosos com a contradição de se valer concomitantemente de discursos opostos ou de substituir um pelo outro. Ele pode depositar a sua esperança na religião, na cura religiosa e abandonar o tratamento médico tradicional, o medicamento (M8, M9) "às vezes o doente se fecha mais para o médico e se abre mais para o religioso" (AR2) - como pode acontecer o contrário. A sua demanda, que ultrapassa a adesão exclusiva a esta ou àquela oferta, é por resultados imediatos.

\title{
7.1.2 O Médico e o seu dom: um poder (quase) religioso ${ }^{346}$
}

\begin{abstract}
Nenhuma outra [profissão] requer dos que a exercem uma doação total [...] Talvez apenas o padre. Ela exige sacrifícios materiais e espirituais, votos de renúncia, uma servidão. O leigo só tem de nós uma impressão superficial, ele nem imagina o que pode ser uma missão que por vezes merece o nome de sacerdócio ${ }^{347}$.
\end{abstract}

Já no começo da civilização grega, com Hipócrates teve início a primeira tentativa de separar medicina e religião ao se procurar fugir de explicações religiosas

\footnotetext{
${ }^{346}$ Psiquiatras (3 bi-posicionados, 1 mono-posicionado, 4 neutros) e religiosos (3 racionalizados) dicorrem sobre a questão.

${ }^{347}$ Dr. Soupault - que na citação faz referência à profissão de médico-cirurgião - no livro Chirurgie, mon métier (1966) citado por Laplantine (2004).
} 
e sobrenaturais para as doenças ${ }^{348}$. Laplantine (2004, p. 215, aspas do autor), nas leituras que realizou sobre a história da medicina, afirma haver constatado a recorrência de uma descrição relativa ao "longo percurso que vai do obscurantismo pré-hipocrático até o surgimento da 'ciência médica' fundamentada na objetivação de desarranjos do corpo". Entretanto, segundo afirma um dos médicos entrevistados nesta tese, mesmo tendo havido a racionalização dos tratamentos ou dos princípios terapêuticos, a questão da espiritualidade nunca foi afastada totalmente ${ }^{349}$. Isso vai se perpetuar ao longo de toda a história da humanidade (M13). A medicina esteve imbricada por longo período da história na religião, consequentemente era a esta que os doentes recorriam em situações de enfermidade. É ponto pacífico, assim, "o fato de os monges terem sido, por muito tempo, os únicos depositários da sabedoria médica clássica no Ocidente e de terem aplicado seus conhecimentos em prol dos doentes" (ANTUNES, 1991, p. 160).

Na ldade Média, por exemplo, os responsáveis por emitir o certificado de médico, o diploma de médico, era [sic] a lgreja. E grande parte dos médicos eram monges, na ldade Média. Isso se perpetua. Aliás, quem constrói os primeiros hospitais e mantém os hospitais até o final do século XVIII foram [sic] as religiões. [...] A medicina vem da religião, começa com a religião. Os primeiros médicos, os primeiros curandeiros eram, na verdade, os grandes iniciados nas religiões. Eram eles que eram os responsáveis pelos tratamentos. (M13).

Embora essa relação não se mantenha ainda tão profunda como antigamente, ela continua sendo preservada, em outros moldes, por meio de uma percepção que consagra a ambas (medicina e religião) um papel salvacionista.

\footnotetext{
${ }^{348}$ Se bem que o próprio juramento de Hipócrates assemelha-se a uma verdadeira profissão de fé (religiosa) com referências a termos - deuses, punição, pureza, promessa, segredo confessional que muito remetem ao universo religioso (ainda que não tivesse sido este o ponto de referência): "Eu juro, por Apolo médico, por Esculápio, Hígia e Panacea, e tomo por testemunhas todos os deuses e todas as deusas, cumprir, segundo meu poder e minha razão, a promessa que se segue: [...] Conservarei imaculada minha vida e minha arte. [...] Àquilo que no exercício ou fora do exercício da profissão e no convívio da sociedade, eu tiver visto ou ouvido, que não seja preciso divulgar, eu conservarei inteiramente secreto. [...] Se eu cumprir este juramento com fidelidade, que me seja dado gozar felizmente da vida e da minha profissão, honrado para sempre entre os homens; se eu dele me afastar ou infringir, o contrário aconteça". (Disponível em: <www.cremesp.org.br> Acesso em: 10/12/09).

${ }^{349}$ Mesmo porque ao se levar_em consideração a definição de saúde proposta pela OMS - um "estado de completo bem-estar físico, mental e social" - é possível atentar para o fato de que "o discurso médico que se apresenta como o mais 'objetivo' e despojado de qualquer pressuposto religioso" (LAPLANTINE, 2004, p. 243, aspas do autor) não faz outra coisa senão "promessas de salvação comuns a todas as religiões"; ou seja, fala de "juventude, beleza, força, serenidade, felicidade e paz". (IBIDEM).
} 
Parece haver na autoridade médica algo de religioso, na medida em que o seu conhecimento (oculto ao paciente) pode trazer melhoras e, em certo sentido, a "salvação" do doente. Nessa direção, o discurso médico é visto como semelhante ao discurso profético, na medida em que ele prediz o futuro e, ao fazê-lo, contribui para produzi-lo. Por conseguinte, o médico pode alterar o curso da doença - mesmo sem a intervenção de medicamentos - a partir do momento em que ele proporciona uma mudança na relação que o doente estabelece com a doença (CLAVREUL, 1983).

[...] entre as muitas experiências religiosas, está a de ser curado, na perspectiva religiosa também chamada de salvação. Os médicos crêem que sua atividade requer experiência clínica e base na racionalidade científica. Não se dão conta do quanto de sua autoridade efetiva é de natureza religiosa em caráter. Esta autoridade deriva do poder último da morte, ao qual a prática médica procura resistir, e a autoridade vem pela posse real, do ponto de vista do paciente, de conhecimento oculto e mágico. (LOTUFONETO, 1997, p. 15).

Good (2003) procura fazer consideração, a partir de reflexão sobre a medicina clínica norte-americana (tomando a Escola de medicina de Harvard), quanto ao papel da medicina na mediação entre fisiologia e soteriologia. Nesse sentido, o autor afirma que, como a enfermidade combina dimensões físicas e existenciais, a medicina por mais baseada que esteja nas ciências naturais, reúne os aspectos moral e material da vida humana. Assim sendo, ela cumpriria uma função soteriológica bem específica nas sociedades modernas, as quais se definem em função de um individualismo materialista. Em conexão a isso, o autor faz referência ao que Weber sugeria quanto ao importante papel das ideias de redenção ou salvação - a compreensão da natureza do sofrimento e dos meios de transformá-lo ou transcendê-lo e conseguir a salvação - na organização da civilização. Defende que na civilização ocidental contemporânea, "la medicina es el núcleo de nuestra visión soteriológica" (GOOD, 2003, p. 138). Assim, ela estaria profundamente envolvida

en nuestra imagen de lo que constituye el sofrimento, del que todos deseamos vernos libres, y en la visión que tiene nuestra cultura de los medios de redención. En una civilización profundamente comprometida con el individualismo biológico, en la que el espíritu es una categoría cada vez más residual, la preservación de la vida humana y la mitigación del sufrimiento físico se han convertido en primordiales. La salud sustituye a la salvación [...] La enfermedad, la 
muerte y la finitud se concretan en el cadáver, em el cuerpo humano. Y la salvación o, por lo menos, uma representación parcial de la misma, está presente en la eficacia técnica de la medicina. (GOOD, 2003, p. 166 e 167, destaque nosso).

O poder que o médico almeja no sentido de controlar a vida e a morte acaba por colocá-lo num "lugar" quase religioso. Além de excluir da sua prática as questões relacionadas à subjetividade, ele mantém uma postura de domínio sobre a finitude, caracterizando-se dessa forma por uma "visão de depositário da vida e da morte" (MINAYO, 2007, p. 245). Nesse sentido, os médicos lidam com a morte como uma oponente (não da vida), mas deles próprios, os quais parecem assumir o papel e vestir a roupa do "guerreiro" que combate a morte. Assim, Laplantine (2004, p. 238), faz referência ao "combate militante", o qual cerra fileiras não somente contra a doença, mas contra a própria morte, a qual passa a ser vista "menos como um limite necessário à vida que como um limite provisório da medicina".

Pelo comportamento médico se pode observar como existe uma crença disfarçada de que a morte pode ser controlada, dominada. Não somente a morte, também a vida e a criação estariam sob seu domínio através da engenheira genética. Acreditamos que não estaríamos sendo demasiado fantasiosos se disséssemos que a aspiração da medicina é a de chegar a ter, de dentro de seus laboratórios, o poder de controlar a vida e a morte. (QUINTANA, 1999, p. 38, destaque nosso).

Aproxima-se da perspectiva do médico enquanto guerreiro e "redentor" tema recorrente em diversas obras segundo informa Laplantine (2004, p. 238) - a ideia (professada pelos próprios médicos) da prática médica enquanto missão, chegando mesmo a ser qualificada como "missão apostólica"350.

O prestígio indiscutível de religiosos e de médicos sustenta-se no conhecimento específico de que são portadores, conhecimento esse que possui o poder de "driblar" a morte e proporcionar a salvação (física e espiritual) ${ }^{351}$, na perspectiva do doente. A credibilidade que é conferida a estes dois campos (médico e religioso) e a seus respectivos discursos continua forte até os dias de hoje, quando "a palavra do médico e do líder religioso tem um peso fundamental na vida das pessoas" (AR1), o que esses profissionais falam tem credibilidade maior junto à

\footnotetext{
${ }^{350}$ Assim qualificada, segundo Laplantine (2004), por Balint.

${ }^{351}$ Laplantine (2004, p. 213) aborda a estreita relação entre saúde e salvação, a qual segundo o autor surge graças as diferentes respostas à questão do porquê da doença.
} 
população ${ }^{352}$ (AR1). O poder que a prescrição dos dois tem é sem precedentes: "O médico fala 'você tem que fazer exercícios tantas vezes por dia para ser mais saudável', a pessoa vai e faz e o religioso também diz 'você precisa fazer isso, aquilo que as coisas boas vão acontecer'” (M24).

Eu acho que, por exemplo, a psicanálise pode se assemelhar muito a questão da confissão. O paciente vai e fala uma série de coisas para o psicanalista. A pessoa religiosa vai e confessa seus pecados. Essa coisa de alívio, de catarse, de poder falar acho que tem muito a ver. [...] A psiquiatria também. Classicamente quem ouve é o psicanalista, terapeuta. O psiquiatra também ouve, claro, mas ele tem uma função de medicar. Ou seja: tem uma coisa ativa. Que também se assemelharia ao padre: "Reza tantos Pais Nossos, tantas Aves Marias e você está perdoado". Existe uma prescrição também por parte do padre, como existe a prescrição do psiquiatra. (M2).

O raciocínio que identifica uma associação entre saúde e salvação ${ }^{353}$, Laplantine (2004, p. 247) apresenta os modos possíveis de acedê-la. Um deles é denominado pelo autor de "a justificação pelas obras", a qual engloba "a saúde como recompensa", de um lado, e "a doença como punição", de outro lado. A primeira associada à obediência às prescrições médicas, a segunda relacionada à desobediência e ao pecado. Nessa perspectiva, onde "a medicina é nossa religião" e onde a saúde passa a ocupar o lugar dantes ocupado pela salvação, é possível falar de desencantamento do mundo às avessas ${ }^{354}$, no qual "a fé médica preenche o vazio deixado pelo desencanto com as grandes religiões em que não mais cremos" (IBIDEM, p. 238).

Tal como observado por Weber (1994), o leigo só teria acesso ao êxtase através do mago, o qual possuiria o saber secreto para tal, sendo, portanto, portador de uma arte própria. Aqui é conveniente apontar-se a semelhança entre o "leigo" que procura o mago e o paciente que procura o médico: ambos acreditam na capacidade dos dois profissionais, acreditam na eficácia de sua ação que deriva de

352 "O médico queira ou não é um líder, se o médico falou... Principalmente essas pessoas um pouco mais humildes, o que o médico falou acaba sendo verdadeiro, bem como o que o padre e o pastor falou". (AR1).

${ }^{353}$ Segundo Laplantine (2004, p. 236), as tentativas de fornecer uma "explicação global do indivíduo e do social", que normalmente eram dadas pela religião, pela política, pela economia, "pela primeira vez na história da humanidade, elas tendem a se tornar sanitárias (e mais precisamente biomédicas)".

${ }^{354}$ Às avessas porque diferentemente do desencantamento do mundo levado a cabo pela ciência, o qual não traz necessariamente um sentido à vida dos homens, o desencantamento do mundo pela medicina, mediante a busca pela saúde (equivalente a salvação nos termos religiosos) garantiria o preenchimento de um vazio. 
conhecimentos apenas detidos por eles, portanto ocultos, ignorados pelo cliente em qualquer das duas situações. Na verdade, o poder de ambos - que "só pode ser plenamente exercido fazendo de seus sacerdotes os detentores de segredos inacessíveis aos profanos" (BOLTANSKI, 2004, p. 40) - está sempre em alerta, pois há o temor constante, dos dois lados, de se ver ameaçado por uma autoridade concorrente (IBIDEM).

Assim como as figuras religiosas, os médicos são vistos quase como sobrehumanos, transcendentais: "De vez em quando me perguntam se eu também adoeço. Claro! [eu respondo]" $(\mathrm{M} 14)^{355}$. Se, de um lado, há uma percepção equivocada dos pacientes em relação à figura do psiquiatra; por outro lado, existe a possibilidade de o próprio profissional considerar "a medicina como uma religião, uma coisa meio dogmática [...]" (M3), transformando dessa forma "a psiquiatria no seu próprio discurso religioso no sentido ruim da palavra religiosa" (M14).

O médico-psiquiatra abraça "o mito da onipotência" (BASAGLIA, 1985, p. 258) que o paciente lhe confere. É por esse poder que lhe é atribuído que ele consegue dar continuidade à sua imagem de todo-poderoso. Soma-se a isso o fato de que, ao contrário dos outros médicos, o psiquiatra possui um poder mais amplo, mediante o qual ele age não apenas "setorialmente sobre uma parte do corpo que pertence ao doente"; em sentido oposto, ele atua "de modo global sobre o doente, que lhe pertence" (IBIDEM). Esse poderio sem limites faz com que o profissional sinta-se "senhor de todas as coisas", como ilustra M17 com o comentário: "O paciente fala 'Graças a Deus eu estou melhor' e o médico responde 'Graças a Deus e ao seu médico'”. É possível que, acredita a depoente, semelhante postura esteja relacionada com a "onipotência do próprio médico", resultado de uma extrapolação de uma autoconfiança exigida pela própria profissão (M17).

Tanto o médico quanto o religioso exercem um poder sobre as pessoas, são profissionais nos quais se deposita uma esperança (M19) num porvir melhor, para os quais se confia o seu corpo e a sua alma. São funções sagradas que chegam a pesar nos ombros daqueles que, pertencentes ao próprio campo religioso, veem

\footnotetext{
${ }^{355}$ Ao analisar o encontro do médico e do religioso no romance popular, Laplantine (2004, p. 246) fala das "qualidades de onipotência e de santidade creditadas aos médicos". O autor aponta para o fato de que nessa literatura os médicos jamais ficam doentes, o que leva a crer que "[...] em medicina como em religião, tudo se passa como se o caminho da salvação só pudesse ser percorrido por aquele que está em perfeita saúde. O Cristo, isento do pecado, era também isento da doença".
} 
essa atribuição com certa ressalva: "Colocaram tanta coisa nas nossas costas! Do padre, do médico" (AR1). A consequência disso é a fabricação de uma imagem distorcida desses especialistas que - por mais que desempenhem um importante papel - não são seres divinos nem exercem funções extraordinárias - "às vezes extrapola um pouco para uma coisa que nós não somos: não somos sagrados, exercemos funções diferentes só. Mas o povão tem isso" (AR1).

As semelhanças estão longe de se esgotar. A competência, habilidade ou inspiração dos dois profissionais passa pela outorga de um ser supremo. Segundo os religiosos "magicizados", o sagrado que existe nos médicos passa por uma concessão de Deus. Eles somente realizam a cura porque Deus os "ilumina": "Não que Deus vai curar o doente, mas Deus está guiando/conduzindo os médicos para que façam alguma coisa nele..." (AR2). Nessa direção também é possível trazer para a reflexão a questão da "vocação" ${ }^{356}$. Esta aparece nas duas especialidades, nas quais normalmente pressupõe-se que para cuidar do sofrimento físico, psicológico ou espiritual há de se possuir um dom especial, uma espécie de chamado.

De certo modo, psiquiatras e religiosos são cuidadores da alma humana: "O psiquiatra como o médico da alma, o nome, né, a psiquê, atria: medicina” (M3). Alma no sentido de mente, de algo que não pode ser visualizado, mas que tem, assim como a primeira, poder sobre o corpo físico e as suas atuações. O xamã, líder religioso e terapêutico, pode ser lembrado no intuito de apontar semelhanças dos dois lados: o psiquiatra cuida da psique (alma) bem como do bem-estar físico, desse modo ele reflete o xamanismo, acredita M14. Assim como os "rituais terapêuticos" (M14) da medicina aparentam-se, em grande medida, com os rituais religiosos: eles vão do simples avental do médico e o manto do religioso até a consulta do médico e o oráculo do religioso, passando pela fé (do paciente) no procedimento do médico e a fé (do fiel) no procedimento da autoridade religiosa ${ }^{357}$. Ou seja, os dois casos são

\footnotetext{
${ }^{356}$ Importante relembrar aqui a reflexão que Bourdieu faz sobre a noção de "vocação", a qual não é outra coisa senão escolhas relacionadas à exposição a condições objetivas diferentes. No final das contas, o campo é o "verdadeiro 'sujeito' das obras humanas mais bem sucedidas" (BOURDIEU, 2001 , p. 140, aspas do autor), pois é graças a ele e contra ele que elas realizam-se.

${ }_{357}$ Pode-se ir além: pensar o consultório médico como uma espécie de confessionário, onde assim como no confessionário religioso, os sujeitos compartilham de questões íntimas, pedem conselho, orientação. Nos dois casos, ao final, são feitas recomendações que, se seguidas, podem "salvar" o sujeito nesta vida (perspectiva médica) e na outra vida (perspectiva religiosa). Ou seja, trata-se de duas propostas declaradas de redenção humana.
} 
permeados por questões parecidas: "Eu acho que envolve fé, ritual, mito. Existe mito também em psiquiatria e muito" (M14).

O campo médico-psiquiátrico, como todos os outros campos, vai se compondo, delineando-se, criando um corpus específico: "A psiquiatria, como, de resto, todo saber erigido em ciência, constitui seu objeto. Vale dizer, 'cria' a loucura, tece ao seu redor a teia do discurso competente, estabelece sutis relações de poder em face do objeto de sua fala essencialmente normativa e impositiva" (CUNHA, 1986, p. 115, aspas da autora). Ele vai se expandindo e, concomitantemente, adquirindo prestígio e poder, graças a uma crescente abrangência de sua área de atuação associada à "definição cada vez maior dos fenômenos como pertencentes ao campo de ação de sua disciplina" (SZASZ, 1979, p. 47).

A loucura torna-se verdade médica. Cria-se uma clínica das enfermidades mentais e uma concepção de terapêutica: o louco, como qualquer doente, necessita de cuidados, de apoio de remédios. Cria-se um corpo de conceitos, a teoria psiquiátrica, que instrumentalizariam esta prática clínica. (BIRMAN, 1978a, p. 2).

Os agentes desse campo - os psiquiatras - vão aos poucos ocupar um "lugar", assim como os religiosos ocuparam em outra época, de donos da verdade. O seu papel é aquele de "árbitro competente encarregado de decidir quem está ou não doente" (SZASZ, 1979, p. 47). Considerando o que Foucault afirma quanto à inversão de poder no interior dos hospitais ${ }^{358}$ que ocorreu no século XVIII - tema sobre o qual já se discorreu neste estudo -, não se pode deixar de notar as características "religiosas" que impregnavam a atuação do médico: "Essa inversão das relações hierárquicas no hospital, a tomada de poder pelo médico, se manifesta no ritual da visita, desfile quase religioso [...] Essa codificação ritual da visita [...] em que se diz onde cada pessoa deve estar colocada, que o médico deve ser anunciado por uma sineta [...]" (FOUCAULT, 1979, p. 110, destaque nosso).

Entretanto, o campo médico com toda a sua conceituação teórica e sua prática clínica, com toda a sua autoridade abre espaço para a participação de práticas de cura não científicas. É o que repara Pereira Neto (2001, p. 20 e 21) ao descrever o campo médico no final do século XIX, quando ele ainda "apresentava

358 "Muitas instituições de saúde tiveram uma origem religiosa - os hospitais, mesmo, como um todo, no mundo, no Brasil, as Santas Casas - e teve um certo tempo nessa tomada de poder desses hospitais pelos médicos e tudo o mais um certo conflito com os grupos religiosos também." (M1). 
baixo poder de resolutibilidade" e abria caminho para outros formatos e concepções de cura. Havia, nessa situação, uma grande concorrência com outras práticas, visando à "conquista e preservação do mercado de serviços de cura" (PEREIRA NETO, 2001, p. 20 e 21). Para além dos muros dos hospitais, outros especialistas "médiuns, espíritas, bruxas, curandeiros, herbanários" (IBIDEM) - estavam a postos apenas aguardando "o momento da convocação" (IBIDEM). Assim, conforme constata o autor, "o monopólio médico, neste campo, não era um fato dado".

$\mathrm{Na}$ prática médica atual, isso pode ser igualmente verificado, visto que, como já apontado em outro momento, antes de o médico ser procurado há todo um percurso passando por diversas instâncias que não a científica: "[...] o psiquiatra é o último a ser procurado ${ }^{359}$ mesmo. A pessoa vai em um clínico geral, vai às vezes na igreja procurar o padre ou o pastor. Eu já recebi casos que foram, entre aspas, encaminhados por religiosos" (M8). Não necessariamente apenas as instâncias religiosas são contactadas ao longo desse percurso; as pessoas podem buscar por recursos disponíveis na própria comunidade, seja por intermédio de familiares, de vizinhos, seja por meio de instituições mais próximas ao local de residência (M14), as quais podem funcionar como uma espécie de filtro do sofrimento humano (M14). Ou seja, as maneiras de se proporcionar o bem-estar são diversas, não existe um único modo de acessar o sofrimento humano e de saná-lo; desse modo não faz sentido a medicina, a psiquiatria colocar-se como exclusiva, fica até mesmo parecendo "um pouco presunçoso a psiquiatria se colocar como um discurso hegemônico, discurso principal ou como principal ferramenta para ajudar o paciente". (M14). Até mesmo porque, acredita-se que é o paciente que vai determinar o tipo de demanda; a última palavra sempre será dele (ou pelo menos deveria ser).

Talvez, pelo fato de o religioso ter um contato mais próximo com as pessoas que sofrem, ele pode ser frequentemente acionado: "Tem coisas que ele (o paciente) não fala para o médico. [...] Os pacientes se curam com o médico, sem o médico ou apesar do médico. Isso é inegável. O efeito da espiritualidade sobre a doença" (AR3). O apoio em outros tipos de terapêuticas pode estar relacionado ao modo nenhum pouco didático ou distanciado com que o médico coloca-se em relação ao

\footnotetext{
${ }^{359} \mathrm{Na}$ dissertação de mestrado desenvolvida pela pesquisadora, intitulada "Religião e migração: revisitando uma velha questão", foi possível entrar em contato com várias situações em que indivíduos procuravam a cura, para além da medicina, em alguma religião, pois o tratamento da doença, se fosse depender só do trabalho do médico, ia ser mais demorado (ASSUNÇÃO, 2004).
} 
doente e à sua doença. Boltanski (2004), na obra As classes sociais e o corpo, afirma que, especificamente no caso dos membros das classes populares, um dos principais méritos reconhecidos ao curandeiro é o fato de ele explicar ao doente a doença de que ele sofre. E, acertadamente, ele explica utilizando "uma linguagem imediatamente acessível", a qual comporta elementos constitutivos de uma determinada classe social. Desse modo, ele "fornece explicações que contêm representações da doença [...]" (BOLTANSKI, 2004, p. 49).

Acredita-se que religião e psiquiatria sejam de fato duas formas de linguagens distintas, não obstante o papel desempenhado por ambas é similar, possui o mesmo propósito ${ }^{360}$ : o bem-estar de quem as procura. Ou seja, elas falam de uma mesma coisa com palavras diferentes, fazem um trabalho muito parecido "com técnicas/estratégias/linguagens diferentes" (M15) visando, pura e simplesmente, "à melhora da pessoa". (M15). O papel equivalente a elas atribuído pode ser o responsável por passar-se de uma empresa a outra sem grandes problemas. Na analogia realizada por Szasz (1978, p. 19) entre a doença mental do mundo contemporâneo e a feitiçaria da Idade Média, ele procura revelar que ambas têm um mesmo "status lógico e empírico", visto que "são conceitos imprecisos e excessivamente abrangentes, livremente adaptáveis a quaisquer usos que deles queiram fazer o sacerdote ou o médico" (IBIDEM). O autor concorda com alguns historiadores quanto ao fato de que "a psiquiatria se desenvolveu na medida em que a perseguição às feiticeiras declinou e desapareceu" (IBIDEM); entretanto, diferentemente desses estudiosos, ele acredita que isso aconteceu devido a uma transformação de uma ideologia religiosa numa ideologia científica: "O alienista substituiu o inquisidor, o insano substituiu a feiticeira" (IBIDEM, p. 20). Nessa mesma linha de pensamento, é possível afirmar que o sacerdócio médico substituiu o sacerdócio religioso e algumas das suas funções, a principal delas: a definição de regras a serem seguidas para a obtenção do bem-estar.

A cultura urbana passou de religiosa a agnóstica. O espaço de representações do bem e do mal transformou-se. [...] A felicidade, na cultura agnóstica e hedonista, pode ser obtida na terra. $O$ maniqueísmo religioso subsiste apenas como forma marginal de representação do bem e do mal [...] $O$ pecado e a culpa não são mais fontes de sofrimento [...] A origem do sofrimento reside, agora,

${ }^{360}$ Quem faz esta afirmação é um psiquiatra mono-posicionado. O mesmo que afirma não valorizar a religião como um dado importante. 
no corpo e no psiquismo, e não mais na alma. [...] O médico tornouse o sacerdote do corpo e o médico-psiquiatra, em particular, do espírito. As regras de conduta, determinadas pelo saber religioso, transformaram-se em regras de higiene mental. A alegria do espírito pode ser obtida, contanto que se conheçam os mandamentos do comportamento sadio e da estrutura psíquica normal. (COSTA, 2007, p. 24, destaques do autor).

Decerto, ideologias que são "bem entrincheiradas" dificilmente são colocadas de lado, um exemplo disso segundo Szasz (1978, p. 16) foi o cristianismo messiânico e é hoje a psiquiatria messiânica. A partir do momento em que premissas básicas de uma ideologia são aceitas, as novas observações são percebidas de acordo com suas imagens e apresentadas em seu vocabulário. Assim, os valores outrora estruturados pela religião (COSTA, 2007, p. 23), ainda que travestidos por nova roupagem, são hoje responsabilidade da psiquiatria, que fazendo parte do saber científico não pode deixar de corresponder ao "mito do saber científico", pelo qual a época atual é dominada. Dessa forma, a tarefa de definir o que é "bom" ou "mau" cabe então ao sacerdócio médico.

\subsection{DOXA NO(S) CAMPO(S): A “VERDADE” SOBRE O OUTRO}

Ó Voltaire! Ó humanidade! Ó imbecilidade! A "verdade", a busca da verdade, tem lá a sua importância; e se o homem a conduz de modo demasiado humano - "Il ne cherche le vrai que pour faire le bien",361 -, aposto que não encontra nada! (Além do bem e do mal, F. Nietzsche, Aspas do autor).

A doxa é o senso comum, o reinado da opinião, o que parece ser evidente, ser uma verdade óbvia e transparente, mas que, no entanto, não passa de ilusão a ser superada. Segundo Bourdieu, "conjunto de pressupostos que os antagonistas admitem como sendo evidentes, aquém de qualquer discussão, porque constituem a condição tácita da discussão"362 (BOURDIEU, 1983a, p. 145). A opinião que os

\footnotetext{
361 "Não busca a verdade senão para fazer o bem".

362 Embora o autor esteja falando da doxa no interior de um campo determinado - onde os agentes "que estão engajados no campo [...] partilham a adesão tácita à mesma doxa que torna possível a
} 
especialistas da saúde mental e os especialistas religiosos possam ter um dos outros, ainda que reproduza a realidade a partir da lente de cada um deles, deve ser encarada com cautela. Ao contrário do adágio que diz "a primeira impressão é a que fica", a busca pela objetividade deve ir além da ingenuidade presente nas opiniões, ultrapasando-as e resgatando o seu real sentido. Procurar-se-á, portanto, ir além do que os depoimentos em si sugerem, averiguando o que de fato está por trás dos diferentes pontos de vista.

As relações entre os campos psiquiátrico e religioso ocorrem tanto sob forma de aproximações, semelhanças, tipos de abordagem, alianças feitas quanto de conflitos, desentendimentos. Verificar como essa relação é percebida pelos profissionais de cada lado, um em relação ao outro, e pelos pacientes em relação a eles é o objetivo central - ainda que dele desdobrem outras reflexões e problematizações não menos relevantes. Existem, portanto, três verdades a serem deslindadas: a "verdade" dos psiquiatras, a "verdade" dos religiosos e a "verdade" dos pacientes ${ }^{363}$. Elas podem ser apreendidas sob a forma seja de reclamações e discordâncias, seja de elogios.

Inicia-se essa reflexão partindo de uma indagação que foi feita no início deste trabalho: quem estará apto a dizer a "verdade" sobre o mundo social?

\subsubsection{A "verdade" dos psiquiatras ${ }^{364}$ sobre o campo religioso}

Cada campo impõe um preço de entrada tácito: "que não entre aqui quem não for geômetra", isto é, que ninguém entre aqui se não estiver pronto a morrer por um teorema. (Razões práticas, Pierre Bourdieu).

Do lado dos profissionais de saúde, a religião é percebida sob diferentes frentes. Aqui se discorrerá sobre os discursos dos psiquiatras em relação às

concorrência entre eles e Ihes impõe seu limite [...]: ela impede de fato o questionamento dos princípios da crença, que ameaçaria a própria existência do campo". (BOURDIEU, 2001, p. 124) aqui a crença, a "verdade" é de um campo em relação ao outro.

363 Esta será apresentada no último capítulo, onde se discorrerá sobre o posicionamento dos pacientes em relação aos campos psiquiátrico e religioso.

${ }^{364}$ No título, é feita referência aos psiquiatras, mas entram aí os posicionamentos dos enfermeiros. 
religiões e aos religiosos, como encaram sua atuação no hospital e o que isso significa para eles enquanto profissionais.

\section{- Verdade n.1: Falta de treinamento ${ }^{365}$}

Os psiquiatras carregam uma visão pessimista com relação à postura de alguns religiosos ${ }^{366}$ que normalmente "não têm preparo" (M6), dando sentido religioso a questões psicológicas, e até mesmo, orientando o paciente a interromper a medicação (M6). Quanto a isso, consideram-se os espíritas sensatos, no sentido de terem uma perspicácia para detectar quando a questão não é religiosa e o paciente necessita de atendimento psicológico/psiquiátrico (M6). O atendimento religioso é reconhecido como importante já que proporciona esperança, suporte tanto para o paciente quanto para a família. No entanto, discorda-se de certos tipos de abordagens religiosas, consideradas descabidas, que acidentalmente acontece de serem postas em prática (M7).

É necessário ao religioso ter um treinamento que o prepare para entender as características do lugar onde ele está atuando, para que saiba com o que está lidando (M17): "Se vou fazer um serviço em uma favela, eu tenho que saber qual risco estou correndo, eu não posso estar pregando exatamente contra a droga do lado de um traficante porque vou levar um tiro" (M17). Ou seja, é importante que se tenha noção dos riscos de não estar atento à proposta fundamental do local. Assim, o que conta não é apenas a boa vontade, mas ter uma formação técnica a respeito (M13), e ainda, ter noção sobre as questões de saúde e doença, os tipos de patologias mais frequentes, as limitações do paciente (M13): "Não é só a boa vontade. [...] Precisam ser treinados a exercer um papel que pode trazer benefícios, mas também pode trazer malefícios para o próprio paciente" (M13). Por fim, é necessário haver discernimento "para não estar falando bobagens", para "não ferir sentimentos" (E4). Vê-se, portanto, que neste ponto psiquiatras e autoridades

\footnotetext{
${ }^{365}$ Psiquiatras (3 bi-posicionados, 7 neutros) e enfermeiros (1 neutro) discorrem sobre a problemática. ${ }^{366}$ Muitas vezes a referência é aos religiosos de um modo geral, bem como a casos que aconteceram em outros momentos e outros lugares, fora do IPQ. Isso mostra que, independente da presença religiosa atuante lá dentro, a religião não deixa de interferir na vida de alguns pacientes (seja positivamente, seja negativamente). Ou seja, existe uma visão que os psiquiatras têm dos religiosos que extrapola o âmbito hospitalar, é uma percepção em relação aos religiosos de um modo geral.
} 
religiosas ficam de acordo. Assim como AR1 fala em outro momento (fazendo referência aos voluntários) que está assustado com a postura dos religiosos, M20 afirma ser "amedrontador" observar (em relação aos religiosos em geral) as pessoas que atuam nessa área, as quais não têm "bagagem" espiritual e muito menos bagagem "ética/filosófica" e cultural (M20).

A ideia de que o religioso deve, primeiramente, entrar em contato para entender do que se trata, saber o que é um pensamento patológico e como lidar com ele (M19), ter conhecimento e uma "vivência pessoal do que é doença mental" (M20) e atentar para os limites de "até onde ele pode ir" (M19), tudo isso é de fundamental importância. Imprescindível, no caso da psiquiatria, ter esse tipo de discernimento. Entretanto, por conta da falta de formação de muitos religiosos, os psiquiatras relatam casos e mostram-se conscientes quanto ao fato de que, muitas vezes, os religiosos colocam "tudo como sendo coisa religiosa"367 (M6) e incentivam o paciente a parar a medicação. Por isso, existem aqueles psiquiatras que acreditam ser importante orientar o paciente, mesmo que ele esteja com delírio, quanto ao fato de a religião ser importante, "mas que é importante também ele tomar o remédio" (M7). A questão está muito relacionada ao que se diz e como se diz, pois dependendo da maneira como é feito pode piorar o quadro de enfermidade. Frisa-se, portanto, que o profissional religioso ideal é aquele que esteja "aberto a entender o funcionamento dos transtornos mentais, o prejuízo que isso traz para o paciente e como se colocar em um momento de crise" (M16). No mínimo, deve haver ética (M20) na postura do religioso. Por isso, sugere-se uma pré-triagem de quem irá fazer o atendimento religioso, de modo a selecionar aqueles que se disponibilizem a uma "formação de como se colocar na situação do ambiente hospitalar" (M14), dando a entender que neste local vigora "um determinado código de comportamento" (M14). É o que sugere, por sua vez, M23, para quem é necessário haver uma "boa triagem", a ponto de o religioso perceber que é outra a perspectiva de religiosidade ${ }^{368}$ no contato com o paciente.

\footnotetext{
${ }^{367}$ Há constatações no sentido inverso também, casos em que a autoridade religiosa aconselha que o paciente seja encaminhado para um tratamento psiquiátrico ao perceber tratar-se de "algo fora do normal" (M8).

${ }^{368}$ M23 toma como exemplo os espíritas, que ele considera não estarem bem treinados: "Não tem cabimento um espírita chegar aqui e começar a dar passe. É uma outra perspectiva da religiosidade o contato com o doente no sentido de ajudá-lo a passar por aquele transe, inclusive o transe da morte".
} 
Aquele antigo quiproquó - entre religião e psiquiatria - do doente mental visto como endemoniado pode aparecer quando religiosos não são "bem treinados" para lidar com a questão da doença mental: "[...] entravam falando que eram religiosos. Chegavam na enfermaria e começavam a falar com o paciente que ele estava com demônio. O paciente ficava assustado (E4)". Acima de tudo, é necessário haver bom senso e apenas o conhecimento pode gerar discernimento (E4). Por isso, é necessário haver um preparo para estas pessoas, pois não basta apenas a boa vontade e o fato de se pertencer a uma igreja. Estão em jogo questões muito delicadas. A maturidade em termos religiosos (no sentido de saber o que se fala e como se fala) e o conhecimento básico no que diz respeito às questões médicas são imprescindíveis para que se concretize um formato de assistência religiosa seminal.

As experiências narradas anteriormente quanto ao caráter não racionalizado dos religiosos que incomoda os psiquiatras - promessas de cura (M7), posturas exaltadas "de religiões que são um pouco mais exuberantes" (M14) - não se restringem aos muros do hospital. Muitos pacientes que fazem tratamento procuram igrejas fora do ambiente hospitalar; nestas ocasiões o paciente psicótico é colocado no papel de endemoniado perante os membros da igreja (M20). O depoente afirma haver testemunhos de colegas de trabalho de outros hospitais que vivenciaram situações análogas. Isso reforça a visão de que é necessário aprender a se portar no ambiente hospitalar, falando a linguagem exigida naquele recinto: "Outro dia teve um problema com um rapaz que vem cantar, um voluntário. Parece que ele veio falar para os pacientes que eles iam ser curados. Aí é que a gente conversou um pouco sobre isso, de que não podia ter esse tipo de abordagem aqui dentro" (M7). Associado a promessas de cura, há também confusões advindas de situação em que o religioso encoraja o paciente a interromper a medicação, como afirma ter acontecido $\mathrm{M} 7$, atitude que resultou na proibição de entrada nas enfermarias.

Com isso, alguns consideram pertinente que se capacite o Comitê de Assistência Religiosa (CARE) para que ele fale uma linguagem médico-científica e não uma linguagem religiosa (M13): "Pelo que eu já conversei com os religiosos, eles não têm formação suficiente para ter uma visão mais crítica sobre essa situação entre espiritualidade e saúde" (M13). A proposta é, de um lado, formar os religiosos com vistas a um "ensino inter-religioso no sentido de quebrar preconceitos e ver que 
cada religião tem a sua particularidade" (M13) e, de outro lado, mudar o conceito de capelania existente no HCFMUSP por outro mais adequado ${ }^{369}$. Conforme acreditam alguns profissionais, o que predomina é uma "visão sectária da assistência religiosa", a qual "deveria ser assistência espiritual e não religiosa" (M13). Na realidade, a capelania deveria ser um trabalho envolvendo a espiritualidade, "um conceito mais geral" (M13). Além do que, segundo M13, "a própria formação dos religiosos não é uma formação de capelania hospitalar, é uma formação em teologia e filosofia". Acredita-se que a formação em capelania auxilia em relação a uma "visão mais libertária, menos preconceituosa" (M13). Nesse caso especificamente, aparecem novamente os EUA como exemplo a ser seguido ${ }^{370}$, agora a referência é ao modelo estruturado de capelania hospitalar, ao comitê de assistência religiosa do referido país, que não existe no mesmo formato no Brasil.

Nos EUA as pessoas, em primeiro lugar, são formadas em capelania. São quatro anos o curso, tem área de ensino inter-religioso. 0 capelão hospitalar é o responsável por prestar assistência religiosa/espiritual aos pacientes que estão internados independente da religião que eles têm. Ele presta assistência $24 \mathrm{~h}$. E não dá para agilizar... chamar o representante daquela religião. Então ele, no papel de capelão, vai ter que prestar assistência para aquela pessoa e, para isso, existe uma visão mais ampla, uma formação que não tem aqui no Brasil. Não existem cursos de capelania hospitalar no Brasil. (M13).

[...] Nos EUA, por exemplo, todos os hospitais que queiram ter a creditação como um hospital de ponta é [sic] obrigado a ter esse comitê [de assistência religiosa] e prestar assistência espiritual para o paciente. Não é só perguntar a religião para o paciente, mas oferecer um suporte/apoio para ele nesse sentido. Se isso não é contemplado pela organização do hospital, ele não recebe a creditação. Mas isso ainda está muito longe dos hospitais brasileiros. Os hospitais brasileiros, por exemplo, só tem cinco hospitais que têm essa creditação lá dos EUA. (M13).

A necessidade de uma visão inter-religiosa, libertária e sem preconceitos conduz inevitavelmente a outra questão que é a da pluralidade religiosa e do conflito relacionada a ela. Questão que abre o próximo tópico.

\footnotetext{
${ }^{369}$ Tomando como parâmetro o modelo existente nos EUA, que está voltado para a espiritualidade de maneira geral sem estar preso a nenhuma religião. Além do que, pontua-se a diferença entre o conceito de capelania hospitalar e o de pastoral da saúde.

${ }^{370} \mathrm{Na}$ abordagem acerca da questão do capital religioso (no Capítulo 4) essa mesma questão apareceu, só que a partir do ponto de vista religioso. Aqui a referência é ao modelo de capelania dos EUA, entretanto, sob a perspectiva médica.
} 
- Verdade n. 2: O monopólio religioso e a não diversidade ${ }^{371}$

O fato de oferecer-se, oficialmente, no HCFMUSP "uma proposta religiosa única" (M10) ${ }^{372}$ mediante apenas duas modalidades de religião, é visto pelos próprios médicos e enfermeiros como algo "invasivo", no sentido de homogeneizarse uma população que não se apresenta como uniforme (M10): "Aqui a gente tem questões de todos os tipos, refugiados que são muçulmanos, que têm crenças outras". A atitude de desqualificação de outras religiões pode ter relação com a falta de treinamento apontada anteriormente, visto que uma deficiência na formação contribui para posturas inadequadas, a disputa religiosa pelo paciente é uma delas. O Comitê de Assistência Religiosa "peca" por sua falta de representatividade ${ }^{373}$, a qual se restringe às "duas religiões majoritárias no Brasil" (M13). Semelhante carência de opções religiosas é observada pelos profissionais de saúde ${ }^{374}$.

Embora se tratando de uma situação de pouca diversificação religiosa, há espaço para reclamações dos psiquiatras com relação a uma postura religiosa que advém de uma lógica de mercado. Como aponta Berger (1985), no contexto de diversidade e pluralismo religioso vivenciados atualmente, a religião é caracterizada como mercadoria, como um produto a ser adquirido por um consumidor. Nesse modelo, há grande probabilidade também de a qualidade do produto oferecido ser discutível. M25 apresenta a sua indignação com tal modelo, no qual é possível ver "as coisas horrorosas que [certas religiões] fazem contra as pessoas" ${ }^{375}$. O depoente

${ }^{371}$ Psiquiatras (1 mono-posicionado, 1 bi-posicionado, 1 neutro) e enfermeiros (1 bi-posicionado, 5 neutros) falam sobre a questão.

372 O que não deixa de ser verdade, já que o cristianismo detém a exclusividade na assistência religiosa hospitalar: "Foi normatizado que todos os religiosos que viessem aqui para conversar com o paciente, fazer culto seriam encaminhados para lá, para a Leni [autoridade evangélica] ou para o padre Anísio para eles darem autorização para entrar". (E4).

${ }^{373}$ Fala-se da possibilidade da representação de mais uma religião no comitê. Entretanto, não é mencionada qual a religião. Além do mais, os entraves para ter acesso a essa vaga são muitos: "A gente então tem que preencher um formulário, fazer um pedido por escrito, tem que ter uma carta de uma autoridade religiosa à qual essa religião pertence, recomendando essa pessoa. Além dessa carta também precisa que o interessado participe de um curso de capacitação que o CARE instituiu aqui no hospital". (M13).

${ }^{374}$ É o que pode ser notado a partir dos relatos a seguir: "Prevalece no hospital é a católica e a evangélica" (E2, E6)/ "Por que só o católico? Cada um tem um tipo de religião" (E7)/ "Se é uma coisa totalmente adequada, acho que todas as religiões estão abertas" (E5)/ "Religião, qualquer uma. Religião é uma coisa que a empresa não pode proibir. Isso é de lei. Cada um tem a sua religião". (E11).

375 Muito provavelmente se a intenção é buscar ser criterioso e fidedigno ao que aponta a história da humanidade, deve-se lembrar as atrocidades cometidas em nome da religião (as pessoas queimadas 
requer instâncias que se responsabilizem, leis que punam os religiosos pelos seus "desatinos". Afinal, se "o conselho médico só pode punir médico" (M25) e se o médico é punido por seu mau comportamento, há de existir quem ou o que responda pelos atos dos religiosos e faça com que sejam, por sua vez, enquadrados. Caso contrário, pode acontecer de, no final das contas, o feitiço voltar-se contra o feiticeiro: "É uma coisa que eu acho preocupante porque depois vem esse negócio de liberdade de religião, começa a misturar a coisa, depois ainda ficam vítimas" (M25).

Acredita-se, dessa forma, que seria prudente que, do mesmo modo que há regras e sanções para outros setores, deveria haver leis regulamentadoras, instâncias que dessem respaldo às vítimas de excessos por parte dos produtores e ofertantes de religiões. Contra posturas inadequadas e exploração da fé talvez fosse oportuno "o uso do modelo 'defesa do consumidor" em resposta "à tapeação e à fraude religiosa, promessas não cumpridas, milagres não acontecidos" (PIERUCCI\&PRANDI, 1996).

\section{- Outras verdades ${ }^{376}$}

Outras verdades aparecem de forma dispersa entre os entrevistados. Verdades que atribuem ao campo psiquiátrico como um todo, mas não a si próprios - a religião como neurose $(\mathrm{M} 1, \mathrm{M} 14)^{377}$; o preconceito do médico porque acha que a religiosidade vai afastar o paciente do tratamento (M22). Verdades do que eles observaram no IPQ - uma relação tranquila (M6, M22); boa convivência (M25); o temor da influência da religião num momento em que o paciente está sem autonomia (M22); a religião é fator importante (E2).

Parece que os serviços religiosos aqui dentro sempre transcorreram tranquilamente e os pacientes com quem eu tive contato, que

nas fogueiras, por exemplo), bem como não se pode deixar de advertir que a psiquiatria também cometeu a sua parcela de horrores com tratamentos rudimentares e invasivos como a lobotomia e o eletrochoque.

${ }^{376}$ Psiquiatras (1 mono-posicionado, 5 bi-posicionados, 9 neutros) e enfermeiros (2 neutros).

377 Talvez, seja possível arriscar afirmar que essa seja a maior das "verdades" que circunda todas as outras. 
freqüentavam os serviços religiosos, se sentiam mais confortados. (M22).

Eu sei que o capelão evangélico vive na sala dos médicos, vai lá conversar, ver algumas coisas. Então, acaba tendo a convivência. [...]. (M25).

$\mathrm{Na}$ psiquiatria, eu sei que o pessoal sempre ficou um pouco preocupado de entrada de religiões porque o paciente não tem autonomia e a gente sempre ficava, pelo menos quando eu era diretor, do paciente não ser influenciado porque ele está em um estado mental que ele não está com a autonomia dele. (M22).

[...] no setor que eu trabalho, a maioria dos pacientes, sendo religioso ou não, vê que a ausência da religião é um fator importante deles [sic]. No meu setor, principalmente, o fator religioso é muito importante, mas é ausente. Tanto é que o chefe de transtorno alimentar sugeriu uma dinâmica religiosa que, no caso, foi chamado um padre para vir e não deu certo. (E2).

Verdades que eles carregam consigo independente de qual a instituição se trate - possibilidade de trabalhar juntos (M6); estabelecer uma aliança terapêutica (M14); religiosos não devem opinar (M10); religião pode interferir tanto para o bem quanto para o mal (M12, M22); cada um deve se ater ao seu campo de trabalho (M19); deve haver ética e discernimento (M20); necessidade de respeito do ponto de vista de ambos os domínios (M21, M23); o necessário conhecimento das questões psiquiátricas (M26); quadros psiquiátricos envolvem temas religiosos ${ }^{378}$ (M6, M26, M2); o abandono de medicação por conta da religião (M25); opiniões religiosas que são contrárias à postura médica (E1); existem religiões que têm aversão à proposta médica (M26); religião como aliada no tratamento (M8, M7, M21).

As opiniões a respeito da religião acontecem tomando como base tanto o contexto particular do IPQ quanto o contexto médico geral. O que evidencia, de um lado, que o fator religião está presente, ainda que de forma marginal, na questão da saúde/doença e destaca, de outro lado, a real relação conflituosa entre medicina e religião.

\footnotetext{
${ }^{378}$ Dentro desta questão aparecem as seguintes frases: "Religião relacionada ao delírio do paciente faz como que a psiquiatria tenha 'bronca' da religião"/"religião mantém o paciente delirante"/"religiões podem fomentar patologias a que o indivíduo está suscetível".
} 


\subsubsection{A "verdade" dos religiosos ${ }^{379}$ sobre o campo psiquiátrico}

Ao contrário dos psiquiatras, as verdades dos religiosos são mais parcas. Há, por um lado, verdades generalizáveis ao campo médico como um todo: hospital como uma casa de milagres (VR3); ideal que os médicos sejam sacerdotes naturais no sentido de serem consoladores e solidários (AR3); a prioridade deve ser do trabalho do médico (AR3); deve ser "cada macaco no seu galho" (VR3); o paciente pode se curar apesar do médico (VR2, AR3); ocorre apropriação e monopólio do paciente por parte do médico (AR3).

Muitos [médicos] são ateus aqui dentro. Eu não digo [que deveriam ser] religiosos carolas, ortodoxos... não é isso, mas que percebam o coração do outro, a necessidade do outro. [...] Ser consolador, solidário. Isso é maravilhoso. Isso vem de uma espiritualidade, de uma percepção espiritual de si mesmo.[...] Já pensou que coisa maravilhosa! O paciente crendo em um médico por ser médico e crendo também nele por ele ser um sacerdote. Não um sacerdote como nós, que recebemos as ordens, essas coisas, não. Mas um sacerdote natural de Deus ali ao lado do doente. Isso é maravilhoso! (AR3)

[Há também] a ideia de superioridade do médico, a ideia de soberania que ele tem a respeito da profissão, do exercício dele. Ele acha que o doente, no hospital, pertence a ele. O termo é esse: pertence. (AR3)

Como diz o ditado muito popular, bem grosseiro: "Cada macaco no seu galho". (VR3)

Por outro lado, há verdades relativas ao IPQ: os psiquiatras toleram a presença religiosa (AR3); há abertura para a participação nas reuniões clínicas (AR1); necessário conquistar o espaço (AR3); são bem receptivos (VR10); enfermeiros têm uma percepção muito mais aguçada da necessidade subjetiva do paciente do que o médico (AR3).

[...] a gente acha, ainda não concluímos ou, se concluímos, foi empiricamente, de que nós aqui no Hospital das Clínicas somos tolerados. Nós somos, muito, chamados para fazer casamento de médicos, mas aqui dentro mesmo não há essa interação perfeita. [...] Há um tempo atrás até falávamos a respeito da gente participar e, para participar, a gente é que tem que abrir o buraco. [...]. Por

\footnotetext{
${ }^{379}$ Religiosos (3 “magicizados”, 2 racionalizados) discorrem sobre a questão.
} 
exemplo: os ministros podem e devem participar das reuniões clínicas. [...] Necessária uma interação muito mais ampla para gente também participar dos destinos do hospital, discutir as questões do hospital de administração. A gente está ali. (AR3)

Assim como nas considerações que os psiquiatras fazem a respeito da religião e dos religiosos, a reflexão feita por estes últimos no que concerne à psiquiatria e aos psiquiatras toma como parâmetro tanto o campo médico como um todo quanto o Instituto de Psiquiatria em específico. As ponderações são realizadas tomando como foco experiências passadas e não apenas os acontecimentos do momento, bem como assumindo como referência outros hospitais e não somente o HCFMUSP. Os religiosos não se atêm a este, trazem para pauta de discussão o posicionamento dos profissionais da área de saúde de um modo geral. Com isso, provavelmente pretendem reforçar o seu ponto de vista, advertindo para o fato de o seu posicionamento não se restringir a uma única instituição hospitalar, ao contrário dirige-se para algo generalizado. No que concerne ao IPQ, em especial, o posicionamento é em relação à falta de espaço para o serviço religioso e a não valorização deste e dos profissionais que dele fazem parte.

\subsection{DUPLA RELAÇÃO: INVASÃO OU RETRADUÇÃO NO CAMPO?}

\subsubsection{Invasão: o lugar do conflito ${ }^{380}$}

$\mathrm{Na}$ dinâmica do campo médico-científico, algumas atitudes parecem ser comuns $^{381}$ : o desinteresse do médico pelo paciente, o preconceito com relação às questões religiosas. Trata-se aqui de um discurso hegemônico com poder, regras, códigos de comportamento, discurso específico. Esse campo, assim como os demais possui regras próprias, uma dinâmica interna. Sua constituição impõe o

\footnotetext{
${ }^{380}$ Psiquiatras (1 mono-posicionado, 4 bi-posicionados, 8 neutros) e enfermeiro (1 neutro) discorrem sobre a questão.

${ }^{381}$ Atitudes com relação ao campo médico como um todo, não especificamente em relação à psiquiatria.
} 
seguimento dessas normas internas, a sua manutenção depende do rigor e do respeito a uma pureza dos seus mecanismos.

[...] existe um universo intermediário que chamo o campo literário, artístico, jurídico ou científico, isto é, o universo no qual estão inseridos os agentes e as instituições que produzem, reproduzem ou difundem a arte, a literatura ou a ciência. Esse universo é um mundo social como os outros, mas que obedece a leis sociais mais ou menos específicas. (BOURDIEU, 2004a, p. 20, destaque do autor).

Quando as normas do campo são desrespeitadas, quando é quebrado o protocolo, conflitos são estabelecidos. Para jogar o jogo de um campo é necessário possuir o "habitus do sentido do jogo" (IDEM, 1996, p. 144). Os agentes que se aventuram a aproximar-se de um campo desconhecido precisam falar o seu idioma. Aqui especificamente é necessário falar a linguagem do campo médico-científico. Linguagem é o termo ideal para ilustrar o que se quer dizer com o necessário entrosamento entre os campos. Falar a mesma linguagem significa, por exemplo, saber como se colocar na situação hospitalar. É o que indicam os depoimentos:

É necessário todo mundo falar a mesma língua porque é muito complicado você sendo médica você fala uma coisa e outra pessoa vem e responde outra. (M11).

Eu acho que ambos precisam conhecer o outro lado, conhecer para poder ter troca porque senão fica uma coisa que fica completamente separado. (M7).

A gente vai ter que ensinar uma linguagem, eles vão ter que ensinar pra gente também [a linguagem deles]. (M18).

A participação de um campo social na dinâmica de outro campo, como foi visto, pode ser contestada. As visões de mundo empunhadas por cada um dos campos não se coadunam. É comum ouvir-se a seguinte frase: "Cada um no seu lugar. Traduzindo: cada macaco no seu galho" (E8). O que mais concretamente aparece nas palavras: "[...] eu acho que médico não mexe com religião e religião não deve mexer com medicina" (M25). Falar a mesma linguagem é um pré-requisito para se fazer parte de um determinado campo $^{382}$, só aqueles que de fato a ele pertencem

${ }^{382}$ Quanto à participação dos médicos no CARE e dos religiosos nas reuniões clínicas, M13 acredita que isso seja positivo, pois "ao mesmo tempo agrega essa questão da espiritualidade dizendo que isso não é uma questão só de fé. Então, eu acho que é benéfico para ambos os lados. Ao mesmo 
tem condições de possuir o conhecimento adequado. Esse é um tipo de argumento muito comum "para desacreditar qualquer conhecimento externo, não autóctone ('você não pode entender', 'é preciso ter vivido isso', 'não é assim que isso acontece, etc'), e contém uma parcela de verdade". (BOURDIEU, 2004b, p. 110). Entretanto, falar a mesma linguagem é tentar uniformizar algo que é impossível de ser padronizado: a diversidade de idiomas que comporta a vida humana.

Acho que é um pouco como o contrário: se a gente começasse a entrar no Mosteiro de São Bento e mexer nas coisas lá e mudar o jardim, mudar os horários de missa. Acho que tem as áreas deles. Acho que eles não têm nem direito de opinar. (M10).

Existem, por outro lado, os profissionais (bi-posicionados e neutros) que veem com mais maleabilidade a questão da aproximação dos dois campos e fazem uma autocrítica ao próprio campo ao qual são pertencentes, dentro do qual existe muito preconceito (M7, M16, M22) contra a religião. Assim, admite-se que a psiquiatria por longo período de tempo colocou-se contra a religião enxergando esta última como "uma força de retrocesso", de impedimento do "pleno desenvolvimento do humano" ou até mesmo encarando-a como "uma neurose, em termos psicanalíticos" (M14). Entretanto, são formas diferentes de ver o mundo (M11). A medicina é pragmática, imediatista, enquanto que a religião "dá uma outra dimensão" (M11). Naturalmente, o limite acaba sendo estabelecido pela própria visão de mundo.

A religião faz a pessoa ter alguma crença do que nós estamos fazendo nesse mundo, a ciência só diz o seguinte: "Você vive setenta anos de idade, morreu, acabou e pronto". As pessoas não se sentem felizes com isso. A gente quer um significado. Por que eu estou vindo aqui no mundo? Então, a filosofia, os valores e a religião tentam dar algo que a ciência não dá. (M22).

O campo médico-psiquiatra pode, por vezes, sofrer pressões externas, mas a elas deve fazer frente, procurando eliminá-las ou, como afirma Bourdieu, refratálas: "Uma das manifestações mais visíveis da autonomia do campo é sua capacidade de refratar, retraduzindo sob uma forma específica as pressões ou as demandas externas". (BOURDIEU, 2004a, p. 22, destaque do autor). O campo

tempo que cientifica, vamos dizer assim, a fé no comitê/na assistência religiosa, ela espiritualiza esse mesmo comitê do ponto de vista científico". (M13). 
científico possui suas imposições que são relativamente independentes das pressões sociais que o envolve. Essas pressões só poderão ser exercidas por intermédio do campo, "são mediatizadas pela lógica do campo" (BOURDIEU, 2004a, p. 22). Ou seja, essa retradução ${ }^{383}$ é uma das evidências da autonomia do campo. Um exemplo é a pressão externa sofrida pelos médicos quando do atendimento aos Testemunhas de Jeová - a situação "mais óbvia" (M24) $)^{384}$ - que proíbem a transfusão de sangue e suscitam assim "discussões éticas clássicas” (M26). Essa é normalmente uma situação delicada com a qual os médicos têm de lidar e que, em algumas situações, eles podem relativizar, retraduzir. Ou seja, "uma religiosidade muito forte" (M26) passa a ser considerada na avaliação dos pacientes, visto que "pode interferir no processo terapêutico, no processo de avaliação médica" (M26). Julga-se importante "saber um pouco de todas as religiões" (M24), pois o médico ao lidar com a vida humana deve "saber o que o indivíduo acredita para não ferir isso" (M24).

Quando não há uma retradução, uma refração, os atritos e as discordâncias se tornam mais visíveis. Daí pode ocorrer de a autonomia do campo ser temporariamente desestabilizada e enfraquecida. Nota-se, então, que as imposições de um outro campo social se fazem presentes e procuram determinar as regras do jogo: "A diferença maior entre um campo e um jogo é que o campo é um jogo no qual as regras do jogo estão elas próprias postas em jogo" (BOURDIEU, 2004a, p. 29). Como já dito, se o campo for autônomo maior poder de refração, de retradução ele terá e "mais as imposições externas serão transfiguradas, a ponto, frequentemente, de se tornarem perfeitamente irreconhecíveis" (IBIDEM, p. 22). Ao contrário, a manifestação direta de problemas externos põe em evidência a heteronomia do campo (IBIDEM).

\footnotetext{
${ }^{383}$ Bourdieu utiliza essa noção para mostrar a relação entre os campos político e econômico e os campos intelectual e literário. É a retradução no campo dominado dos pedidos dos dominantes; por exemplo, como a política, a economia influenciam o campo literário. Ao contrário, o que se vê ocorrer aqui é a retradução no campo dominante (psiquiátrico) dos pedidos dos dominados (religiosos). Intrigante este acontecimento, pois se são dominantes, por que precisam realizar esta retradução? Uma resposta possível é a de que existe a liberdade de escolha do paciente, a demanda.

384 O caso dos Testemunhas de Jeová, apesar de não ser uma situação vivenciada no IPQ diretamente, é trazida como exemplo por se tratar de situação limítrofre (caso de vida ou morte) que os médicos em geral já vivenciaram de algum modo ou ouviram comentários de colegas. São tão conhecidas e recorrentes que se faz referência a elas como "essas situações clássicas dos Testemunhas de Jeová". (M26).
} 
A interferência direta de religiões como a Testemunha de Jeová, o judaísmo, o neopentecostalismo, por exemplo, na dinâmica do campo médico pode, por seu turno, indicar a ausência de retradução. Nesse caso, pode acontecer o que um entrevistado lembra bem: "Eu acho que se um pisar no calo do outro sai briga" (M25). Os depoentes apresentam a dificuldade de trabalhar numa situação de interferência externa como essa, a qual frusta a equipe (M10); dificulta o trabalho do médico (M14). Algumas religiões neopentecostais são mal vistas, pois "reforçam o discurso da possessão" e dificultam a estabilização do paciente (M14). Os Testemunhas de Jeová são responsabilizados por impedirem que o médico salve vidas (M3). Eles também, juntamente com os judeus ortodoxos, são apontados como aqueles que consomem os recursos do hospital. Os desabafos são em função de a instituição de saúde ser obrigada a gastar inutilmente os seus recursos ${ }^{385}$, medicamentos - já que poderiam ser usados de forma mais eficiente com pessoas que realmente queiram e estejam envolvidas no tratamento - "em nome da religião" (M10). Além do consumo desnecessário de recursos, os princípios e a ética médica são colocados em questão, na medida em que o médico tenta "salvar o paciente" e a família ameaça processá-lo ${ }^{386}$ (M22). Para um médico, passar por cima do código de ética é inaceitável (M2): "Se eu não puder salvar vida vou estar desonrando o meu juramento". Resumindo: é ter um direito invadido, no caso, o direito de exercer a profissão médica com ética.

A reivindicação de autonomia é retomada nesses momentos críticos em que o profissional se vê paralisado diante de algumas situações que se colocam apesar da sua suposta autonomia. Uma reivindicação que teve início há muito tempo e que prega "o direito dos cientistas a decidir as questões científicas ('a matemática aos matemáticos') em nome da legitimidade específica que lhes confere sua competência" (BOURDIEU, 1983a, p. 142).

Associada à questão da autonomia do campo está a não abertura a fatores externos: "Lugar de padre pra mim é na igreja" (M2); "Talvez eu ache que não seja o hospital o local para isso" (M15). A comunidade acadêmica cria barreiras à entrada

\footnotetext{
${ }^{385} \mathrm{M} 10$ faz referência aos judeus ortodoxos e à postura religiosa adotada por eles na qual "não pode fazer determinada coisa depois de determinado horário, não pode comer não sei o quê". M22 cita o caso de uma paciente judia, anoréxica nervosa, que "está se baseando na religião" para não comer: "Não posso comer isso, não posso comer aquilo, não posso comer nada do que o hospital tenha". (M22).

${ }^{386}$ Como é comum em relação às polêmicas com os Testemunhas de Jeová.
} 
de forças não científicas. Para manter a autonomia e a pureza do campo é preciso fazer com que, na luta científica, apenas aqueles que são seus porta-vozes tenham a devida credibilidade: "Eu acho que o nosso trabalho é delimitado à parte médica e, claro, psicoterapêutica também" (M15). Cientificidade e autonomia estão diretamente relacionadas, o que faz com que o progresso de uma se dê a partir da manutenção da outra, realidade apenas possível de se concretizar "[...] criando barreiras na entrada, excluindo a introdução e a utilização de armas não-específicas, favorecendo formas reguladas de competição, somente submetidas às imposições da coerência lógica e da verificação experimental” (BOURDIEU, 2004a, p. 42). A religião pode ser encarada como um fator externo contraventor. Por exemplo, "grupos espíritas que são contra o tratamento porque acham que o paciente tem espírito obsessor" (M2). Esse tipo de interferência é vista como contraproducente ao tratamento (M2): "Eu só acho problema quando passa a interferir na ciência, quando o dogma passa a ser mais importante" (M6).

Se o campo se torna heterônomo, segundo Bourdieu (2004a, p. 32), a concorrência torna-se imperfeita "e é mais lícito para os agentes fazer intervir forças não-científicas nas lutas científicas". Ao contrário, quanto mais um campo é autônomo mais ele se aproxima de uma concorrência pura e perfeita e mais "a censura é puramente científica e exclui a intervenção de forças puramente sociais [...]" (IBIDEM). O que dizer então dos profissionais de saúde mental que abrem as portas para discutir a religiosidade/espiritualidade relacionada à saúde ${ }^{387}$ ? Eles estariam colocando em risco a autonomia do campo? Ou eles estariam apenas fazendo uma retradução dentro do campo? M1 afirma sempre ter havido um temor, no que concerne à mistura de ciência e religião, no sentido de uma imposição de crenças $^{388}$. Entretanto, o depoente acredita ter ocorrido, na verdade, uma "imposição inversa", pois ao se "interditar de falar sobre religiosidade" - a qual é importante para a maior parte da população do mundo - o que se faz é forçar "uma secularização da humanidade que não ocorreu" (M1).

\footnotetext{
387 Segundo M13, pesquisas mostram que se o médico afirma ser religioso ou se discute essa questão com o paciente, este terá um aumento de confiança no profissional, o que, consequentemente, poderá ajudá-lo a aderir ao tratamento, a observar as condutas que o médico prescreve (M13).

${ }^{888}$ Uma visão negativa que prevaleceu por muito tempo, segundo $M 1$, no campo da psiquiatria e da psicologia: "Então, nós fomos formados com essa visão" (M1).
} 


\subsubsection{Retradução: o lugar do diálogo ${ }^{389}$}

A retradução, parece, é uma forma de proporcionar diálogo sem que haja um embate direto entre os campos; afinal de contas, não é sempre possível desbancar o campo concorrente: "E aí você querer argumentar contra a religião é praticamente impossível" (M11). A estratégia de sobrevivência do campo e sua autonomia estão nessa capacidade que ele tem de não se curvar às pressões externas, sejam elas religiosas, políticas, etc, mas ao contrário, reformular o discurso utilizando de estratégias que joguem a seu favor. A relação, por exemplo, do kardecismo com a ciência levada a cabo por alguns médicos é de certa maneira uma forma de retraduzir. Quando o espiritismo se propõe a ser uma ciência da espiritualidade ${ }^{390}$ e alguns médicos tomam isso como uma verdade eles estão de certa forma refratando um contato que em vez de acontecer na forma de um embate, se dá sob a forma de um diálogo.

A partir do momento em que alguns médicos mostram-se abertos a: entrar em contato com a visão dos religiosos; saber qual é o ponto de vista deles (M3); aproveitar o aspecto religioso como instrumento terapêutico (M6); pensar na possibilidade de estabelecer uma "aliança terapêutica" entre médicos e religiosos (M14); questionar a presunção da psiquiatria em colocar-se como um discurso hegemônico (M14), a partir desse momento pode ocorrer a retradução. É importante a busca por um "discurso conciliatório" (M14) para que seja possível "dirimir determinados preconceitos e resistências", visto que a religão pode ajudar na melhora do indivíduo, acreditam alguns profissionais de saúde.

Retraduzir é estar aberto a uma multiplicidade de discursos, buscar uma atitude mais apaziguadora, não excluir as outras percepções que possam existir sobre a vida (M14). Mesmo que em alguns pontos os valores da ciência e da religião entrechoquem, a opção por uma não invalida a outra (M18). Com exceção dos profissionais mono-posicionados, fala-se de flexibilidade e contrapontos (E4), da possibilidade de "razoavelmente transitar entre a medicina e a religião sem muito

\footnotetext{
${ }^{389}$ Psiquiatras (2 mono-posicionados, 4 bi-posicionados, 8 neutros) e enfermeiros (2 neutros) falam sobre a questão.

${ }^{390}$ Os espíritas mostram-se mais interessados pela interface entre espiritualidade e ciência, visto que um dos pressupostos do qual partem é o da "relação entre ciência e espiritualidade" (M1).
} 
conflito" (M16). É possível ser maleável como M23 - que conhece os religiosos, já participou das reuniões deles e até assistiu missa quando convidado - bem como é possível respeitar a espiritualidade dos pacientes como M19 - que assim procede ${ }^{391}$ e acredita que os colegas de profissão também agem da mesma forma. Ou ainda como E9 que, por sua vez, já dialogou com um Testemunha de Jeová sobre a transfusão de sangue e convenceu-se da validade do seu argumento ${ }^{392}$ contra a transfusão de sangue.

Entretanto, retraduzir não significa jogar o jogo duplo: "O que me preocupa é se a pessoa excede e acaba confundindo discurso religioso com o discurso médico" (M14). Bourdieu diz que existe uma possibilidade de sair do campo sem haver realmente saído dele, dá como exemplo os bispos sociólogos, fazendo notar assim que "a fronteira do campo religioso se tornou imprecisa" (BOURDIEU, 2004b, p. 109). Psiquiatras bi-posicionados podem estar investidos desse mesmo caráter ambíguo $^{393}$. Trata-se aí do jogo duplo e da dupla vantagem que possibilita acumular as vantagens da "cientificidade (aparente)" e da religiosidade (IBIDEM, p. 112). No entanto, jogar o jogo duplo de pertencer a dois campos distintos pode desacreditar aquele que o faz.

É necessário não ter uma postura de presunção, perceber que a religião pode ser uma aliada na melhora do paciente; entretanto, não se deve esquecer o lugar que cada um ocupa. O ideal, nas palavras de M14, é jamais se descuidar de que se está ali no papel de médico, porém "aberto em questões religiosas". Pois, afinal de contas, se o médico foi procurado é porque, de certa forma, o sujeito "está buscando a medicina". É preciso resguardar a função ocupada, "se eu estou nessa posição é para ser um psiquiatra" (M14). O preocupante, segundo M14, é o contrário: profissionais, o que porventura pode ocorrer ${ }^{394}$, que acabam "passando

\footnotetext{
${ }^{391}$ M19 pensa que uma abordagem espiritual em paralelo à abordagem médica pode proporcionar conforto ao paciente num momento em que "ele está doente porque é uma situação limite" (M19).

392 Conforme E9: "Tem até médicos Testemunha de Jeová que fazem outro tipo de terapêutica que não precise [sic] de sangue e me convenceram, realmente, que os prejuízos para receber sangue são muito maiores do que não receber". (E9).

${ }^{393}$ Esta atitude ambígua do psiquiatra bi-posicionado não deve ser confundida com aquela do psiquiatra neutro/ambíguo. A ambiguidade do primeiro reside, hipoteticamente, no fato de pertencer a dois mundos distintos, assumidamente, fazendo as vezes do campo psiquiátrico e do campo religioso. Já no segundo caso, o caráter ambíguo reside justamente no fato de um pertencimento/não pertencimento, visto que ao mesmo tempo em que faz ressalvas ao contato com a religião, posicionase tolerante em relação a ela. Ou seja, não assume nem uma oposição clara, nem uma permissividade declarada em relação à presença religiosa.

394 "Eu vejo alguns colegas que têm um discurso místico acientífico, acrítico" (M14).
} 
para um discurso místico no sentido ruim do termo" (M14). Nesses casos, o profissional "excede e acaba confundindo discurso religioso com discurso médico", o que resultará na atitude inconveniente de lançar mão "apenas de argumentos/proposições religiosos para tratar um problema que eminentemente é um problema médico"395 (M14).

É importante a questão do perigo de o profissional jogar um jogo duplo dentro do campo ${ }^{396}$ (como já apontado anteriormente). Um profissional médico que é religioso corre o risco de viver uma relação ambígua no campo científico, produzindo "uma espécie de ciência edificante, destinada, a servir de fundamento a uma religiosidade científica, permitindo acumular as vantagens da lucidez científica e as vantagens da fidelidade religiosa" (BOURDIEU, 2004b, p. 112-113). Trata-se da "tentação do jogo duplo e da dupla vantagem", que tem por trás de si a recusa da “objetivação das adesões” (IBIDEM).

A retradução feita pelo campo médico-científico talvez ocorra por conta de pessoas que, dentro dele, possuem visões específicas. As tomadas de posição possibilitam que haja um rearranjo nos jogos do campo, visto que os agentes sociais resistem às suas forças, "não são partículas passivamente conduzidas pelas forças do campo" (BOURDIEU, 2004a, p. 28).

Ou seja, o campo médico assim como o campo científico de um modo geral é elaborado a partir da posição que os agentes nele ocupam. Esses agentes "fazem os fatos científicos" (IBIDEM, p. 25) por intermédio da posição que ocupam, mas a qual não fizeram (IBIDEM). E é essa posição que é, em última instância, responsável pela tomada de posição (IBIDEM, p. 23).

Esses profissionais que possuem visões específicas, ou seja, que tomam uma posição dentro do campo, para conquistar "a palavra" precisam possuir um capital científico considerável, este diz respeito a uma "espécie particular do capital

\footnotetext{
395 Pode haver uma interferência no tratamento, por exemplo, no sentido de o "paciente escolher determinados profissionais de acordo com a crença religiosa de cada um e a contaminação da prática médica por esse preceito religioso" (M19). Havendo essa contaminação, o depoente acredita que é negativo, principalmente na psiquiatria: "Essa dificuldade de separar o que é uma busca sadia de uma busca patológica que tem a ver com a doença mental. Vai procurar um profissional daquela religião porque ele usa aquela religião ou os conhecimentos da religião para curar. Aí eu acho negativo" (M19).

396 Segundo Bourdieu, o jogo duplo e a dupla vantagem ameaçam principalmente os especialistas das grandes religiões universais. Exemplo: católicos que estudam o catolicismo, protestantes 0 protestantismo. Aqui se faz referência ao que se denominou psiquiatras bi-posicionados.
} 
simbólico que consiste no reconhecimento (ou no crédito) atribuído pelo conjunto de pares-concorrentes no interior do campo científico" (BOURDIEU, 2004a, p. 26). Ou seja, os agentes que querem opor-se às regras do próprio campo do qual fazem parte, devem possuir forças dentro dele, isso quer dizer que eles precisam ter um capital científico à altura. Caso contrário, dificilmente eles serão escutados ou minimamente respeitados em seus argumentos. Muito provavelmente eles poderão ser questionados nas suas atitudes, descreditados por seus pares-concorrentes. É o caso do fator anti-tenure relatado no tópico "Estudos em saúde e espiritualidade", do capítulo terceiro.

[...] é preciso, primeiramente, lembrar que nada é mais difícil e até mesmo é impossível de 'manipular' do que um campo. [...] As oportunidades que um agente singular tem de submeter as forças do campo aos seus desejos são proporcionais à sua força sobre o campo, isto é, ao seu capital de crédito científico ou, mais precisamente, à sua posição na estrutura da distribuição do capital. (IBIDEM, p. 25).

Uma questão pertinente a fazer nesse momento é: com a "invasão" do domínio religioso pelos psiquiatras bi-posicionados estaria a psiquiatria se deslaicizando? Estaria ocorrendo uma "redefinição das competências" (BOURDIEU, 2004b, p. 121) no interior do campo médico, o qual passa a ser composto por uma medicina científica e uma medicina religiosa/espiritualizada? Talvez outra indagação adequada a fazer, fora aquela da entrada de religiosos no campo médico, é: por que os médicos entram no campo religioso? Seria, quem sabe, uma "invasão" às avessas? Ou, ainda, tratar-se-ia de uma redefinição de competências no interior do próprio campo religioso? Redefinição que vai acontecendo no decorrer dos tempos resultado do fato de que "os próprios limites entre o campo religioso e os outros campos, e em particular com a medicina, foram transformados" (IBIDEM).

Onde se tinha um campo religioso distinto tem-se a partir de então um campo religioso de onde se sai sem saber, ainda apenas que biograficamente, já que muitos clérigos se tornaram psicanalistas, psicólogos, assistentes sociais, etc, e exercem novas formas de cura das almas com um estatuto de leigos e sob uma forma laicizada; assiste-se então a uma redefinição dos limites do campo religioso, à dissolução do religioso em um campo mais amplo, que se acompanha de uma perda do monopólio da cura das almas no sentido antigo [...]. (IBIDEM, p. 122, destaque do autor). 
Pode tratar-se de uma laicização da prática religiosa que se vale de discurso científico para sobreviver. A experiência de um outro formato do campo religioso? Trata-se, quem sabe, de um outro estágio desse campo? Mudanças vêm ocorrendo, pode-se estar assistindo possivelmente à instauração de "um novo campo de lutas pela manipulação simbólica da condução da vida privada e a orientação da visão de mundo" (BOURDIEU, 2004b, p. 121).

\subsubsection{O(s) autor(es) da retradução ${ }^{397}$}

Muito provavelmente o médico responsável pela retradução não teria como exemplo paradigmático o que sugere M6 a respeito de alguns colegas: "Tem médico que diz: 'Não tem nada de religião, não, rapaz. Quem vai te curar é o remédio, mesmo"” (M6). Um exemplo infenso ao anterior é o de M24: "Eu acho que dá para conciliar muito bem espiritualidade e psiquiatria, da mesma maneira que eu sou espírita" (M24).

O que se quer afirmar com isso é que a possibidade de ocorrer uma retradução passa pela capacidade, mínima que seja, do estabelecimento de diálogo em contraposição a um embate direto. O psiquiatra purista/ortodoxo não estará disposto a semelhante atuação, esta cabe àqueles que, por algum motivo dentro do campo psiquiátrico - seja a busca por equilíbrio de poder, seja a busca por um novo modelo de prática - desejam algumas mudanças: os psiquiatras neutros/ambíguos e os bi-posicionados. Dessa forma, o bi-posicionamento, a neutralidade/ambiguidade implicam no afastamento da ortodoxia do campo psiquiátrico, visto que neste, assim como em religião, "o politeísmo é sempre possível [...] existem cismas, heresias, crenças autóctones [...]" (LAPLANTINE, 2004, p. 242).

Se, por um lado, como já salientado em outro momento desta tese (no tópico Estudos sobre saúde e espiritualidade), a mudança de pesquisadores em direção a novos objetos de estudo está relacionada à alta competitividade em torno de determinados objetos; por outro lado, essa mesma migração e importação de capital de um campo socialmente superior para outro campo pode ocorrer devido a sujeitos

\footnotetext{
${ }^{397}$ Psiquiatras (1 bi-posicionado, 2 neutros) discorrem sobre a questão.
} 
detentores de um grande capital científico, que por questões outras (secundárias) "se encontram numa posição de desequilíbrio própria a favorecer uma inclinação revolucionária" (BOURDIEU, 1983a). São estes os responsáveis pelas "revoluções inaugurais que dão nascimento a um novo campo, constituindo, pela ruptura, um novo domínio de objetividade" (IBIDEM).

O psiquiatra bi-posicionado é aquele que é engajado abertamente na defesa da presença religiosa e da abertura para questões religiosas no IPQ. Os motivos que conduzem esses profissionais a seguirem esse caminho não é possível afirmar com segurança quais são. A despeito dos incentivos que os levaram a assim proceder, o que é possível assegurar é que converter um capital científico puro em capital científico-religioso, como fazem os bi-posicionados, poderá ser levado a cabo, mas somente "sob certas condições" (BOURDIEU, 1983b, p. 90) e uma delas é a de ter o seu capital específico sujeito “à mais desfavorável taxa de conversão”398.

Por pertencerem ao campo científico e serem "espiritualistas", os psiquiatras bi-posicionados, ao trazerem questões espirituais/religiosas para o campo psiquiátrico, dependerão da retradução que conseguirão colocar em prática neste campo. Considerando a dificuldade em se transmutar a religião no campo científico, os referidos profissionais por mais "neutros" que sejam ao tratar dessa temática, deixarão de fora sua formação religiosa/espiritual? A retradução perfeita (que impossibilita o descrédito) dar-se-á provavelmente mediante uma construção intelectualizada sob a forma científica, a qual faça com que os que acompanham os debates não associem qualquer religiosidade/espiritualidade a esses profissionais. Para objetivar o seu posicionamento no campo psiquiátrico e ser o mais fiel ao campo científico é necessário que esses psiquiatras, ao realizarem o seu trabalho levem em consideração que há questões que surgem enquanto sujeitos religiosos/espiritualizados e não enquanto cientistas. Essa realidade, que é uma via de mão dupla - conduz ao rebaixamento ou à retradução -, pode ser pensada também em termos de objetivação e não objetivação. Assim, de um lado, ao invés de conduzir ao rebaixamento no campo psiquiátrico, será uma forma de objetivar o sujeito da objetivação, como afirma Bourdieu. Ou, de outro lado, poderá significar

\footnotetext{
${ }^{398}$ Bourdieu (1983b, p. 90) exemplifica com o caso do fracasso de Cardin que "quis transferir para a alta cultura um capital acumulado na alta costura: o último crítico dos críticos de arte teve que afirmar sua superioridade estrutural como membro de um campo estruturalmente mais legítimo, dizendo que tudo o que Cardin fazia em matéria de arte legítima era detestável, impondo assim a seu capital a mais desfavorável taxa de conversão".
} 
que estes psiquiatras com "ouvido musical para religião" (no sentido de Weber) não conseguiram retraduzir na forma do capital do campo científico.

Alguns depoentes fazem referência à mudança de paradigmas na medicina (um mono-posicionado e o outro neutro). O primeiro fala em necessidade de mudanças, o outro fala da concretização, da efetivação dessa mudança no sentido do acolhimento do ProSER pelo Instituto de Psiquiatria. Uma mudança paradigmática traduz-se em invasão ou não? Pode não representar invasão se pensada em relação ao posicionamento que os psiquiatras bi-posicionados defendem. Eles se posicionam nas bordas, saem do núcleo duro (como já afirmado por um psiquiatra bi-posicionado com relação ao posicionamento religioso) da psiquiatria.

Entretanto, a mudança de paradigmas e a retradução não é assunto que diga respeito apenas aos bi-posicionados. Por mais contrassenso que seja, parece ser a anfibologia do psiquiatra neutro/ambíguo (a mais incidente) com seu caráter difuso - que se infiltra mais rapidamente e se alastra no campo psiquiátrico - a que possibilita uma abertura e, portanto, uma disponibilidade de retradução dos pedidos que venham do mundo religioso. Isso, não pela intensidade, mas pelo alcance maior que ela consegue mediante uma discrição, graças ao seu comportamento não assumido.

Ainda que o pensar médico esteja impregnado do cartesianismo das ciências (exatas), na ciência médica - especificamente na psiquiátrica - há mais ambiguidade, flexibilidade. Pode ser que essa indefinição - a qual comporta imponderáveis - reflita a questão do "neutro". Nessa mesma direção, é possível pensar que a "vagueza" propiciada pela religião - em oposição ao engessamento da ciência - repercuta, por seu turno, a questão do "neutro". Esses profissionais considerados "neutros" não se tomam por religiosos/espiritualistas, mas têm um posicionamento que se pretende maleável, intermediário, porquanto não se enquadram no modelo científico tal qual ele se apresenta aos seus seguidores. Tal fato os faz defender a ideia de que quanto mais a medicina aproximou-se do "caráter científico, comprobatório mais se afastou da religião" (M16). Há dúvidas no quanto isso é positivo, pois voltar-se estritamente para o lado científico e ignorar a presença da religião faz com que se perca algo (M16), visto que ela é importante na vida das pessoas e, portanto, possui "algum significado que tem de ser considerado" (M16). 
Parece significativo e oportuno refletir aqui sobre o par psiquiatra biposicionado/psiquiatra neutro tal qual a dicotomia estabelecidos/outsiders ${ }^{399}$ apresentada por Elias para pensar sobre as relações de poder - que se assenta na contraposição entre "membros da 'boa sociedade"” e os que estão de fora dela. O que se quer apontar com isto? Essa dicotomia revela, na verdade, uma relação de poder $^{400}$ e ao mesmo tempo de interdependência ${ }^{401}$ : o grupo de psiquiatras biposicionados apresenta-se neste contexto como os outsiders, aqueles que são estigmatizados pelo grupo majoritário (o establishment ${ }^{402}$ ), e que, no entanto, mantém com estes uma relação de interdependência, onde dominantes e dominados estão enredados num mesmo mecanismo societário ${ }^{403}$. Questionando a separação que comumente ocorre entre indivíduo e contexto social ${ }^{404}$, Elias faz com que se perceba a importância de colocar lado a lado o homem e sua época.

399 Segundo Elias (2000, p. 7), os outsiders são "um conjunto heterogêneo e difuso de pessoas unidas por laços sociais menos intensos do que aqueles que unem os established. A identidade social destes últimos é a de um grupo. Eles possuem um substantivo abstrato que os define como um coletivo: são o establishment. Os outsiders, ao contrário, existem sempre no plural, não constituindo propriamente um grupo social".

${ }^{400} \mathrm{O}$ par estabelecidos-outsiders lança luz sobre uma dimensão importante da vida social que são as relações de poder, as quais têm por elementos: "Superioridade social e moral, autopercepção e reconhecimento, pertencimento e exclusão". (ELIAS, 2000, p. 8).

${ }^{401}$ Conforme pensa Elias, as categorias estabelecidos e outsiders "se definem na relação que as nega e que as constitui como identidades sociais. Os indivíduos que fazem parte de ambas estão, ao mesmo tempo, separados e unidos por um laço tenso e desigual de interdependência". (IBIDEM, destaque nosso).

402 Trata-se da "'minoria dos melhores' nos mundos sociais mais diversos: os guardiães [...] da excelência científica”. (IBIDEM, p. 7).

${ }^{403}$ Norbert Elias procura mostrar que diferenças individuais e mudanças estruturais andam juntas, não estando o indivíduo imune às profundas transformações sociais. O que faz com que o autor afirme que as "decisões individuais ficam obscuras quando não se consideram os aspectos relevantes dos processos sociais não planejados em que ocorrem”. (ELIAS, 1995, p. 48).

${ }^{404}$ Ao mergulhar na análise sobre a relação indivíduo/sociedade, em Mozart: sociologia de um gênio, Elias procura mostrar que "mudanças específicas no padrão de criação artística estão vinculadas a uma mudança social" (IBIDEM). Um exemplo disso é o fato de Mozart estar envolvido por um processo social não planejado, o de tentar a sorte como "artista autônomo" em Viena. No caso de Mozart, por exemplo, a separação entre o artista e o homem é artificial, enganadora. Isso porque nenhuma consciência, qualquer que seja, "não é inata a ninguém"; ao contrário, toda e qualquer consciência individual é específica a uma determinada sociedade. O autor faz a movimentação explicativa entre os níveis macro e micro de análise. Assim procedendo ele coloca em evidência que Mozart não buscou a posição de "artista autônomo" apenas por vontade própria, ele foi levado a isso por questões alheias à sua vontade, questões que estão relacionadas a uma estrutura maior de poder na qual ele estava inserido, e no interior da qual fazia parte do polo dominado, ou seja, há um nível macro na análise que é a relação outsiders versus establishment. Elias alerta, entretanto, para o fato de que essa atitude de Mozart não pode ser claramente compreendida se sua relação com a sociedade de corte for encarada de forma puramente negativa. Era uma relação ao mesmo tempo de irritação com os padrões da corte, mas também de desejo de reconhecimento por esta, ele queria ser tratado como igual pela aristocracia. Ou seja, era uma relação ambígua. Esse desejo de aceitação, de sentir-se igual é recorrente na relação outsiders-establishment. 
Os neutros estariam mais próximos da situação de establishment já que, eles sim (e não os psiquiatras bi-posicionados) procuram garantir seu lugar no polo dominante, o que ocorre mediante um possível jogo duplo no campo, tirando proveito das duas situações. Os referidos sujeitos não realizam o sacrifício do intelecto e tampouco o enfrentamento das escolhas últimas. O necessário sacrifício do intelecto - "feito para dar-se incondicionalmente a uma religião, é moralmente superior à arte de fugir a um claro dever de probidade intelectual, que se põe quando não existe a coragem de enfrentar claramente as escolhas últimas" (WEBER, 1993, p. 51) - que deve ser feito pelo religioso é o equivalente à busca por clareza e o enfrentamento das escolhas do cientista, o qual "terá de decidir, de seu próprio ponto de vista, o que, para ele, é deus e o que é diabo [...] se deseja se defrontar com essa espécie de diabo, não caberá optar pela fuga, tal como acontece muito frequentemente em nossos dias, mas será necessário examinar a fundo os caminhos que trilha, para conhecer-lhe o poder e as limitações [...]". (IDEM, p. 42, 47, destaque do autor).

Os psiquiatras bi-posicionados "dão a cara a tapa" - isso parece claro - ao se exporem ao preconceito do campo. Entretanto, até que ponto esses profissionais enfrentam suas escolhas últimas e não fogem à probidade intelectual? A escolha entre um deus e um diabo faz-se necessária para a "lucidez" científica. Do mesmo modo, deve-se indagar se no jogo duplo dos neutros as escolhas (os deuses e os diabos) são assumidas. Aquele que tem "ouvido musical para a religião" deve ser classificado como o que age de má fé ou deve ser visto antes como o que faz as escolhas e responde por elas? Os neutros se abstêm de um deus ou diabo e assim não assumem os interesses que estão contidos no jogo científico, necessários para uma objetivação do sujeito objetivante, como diria Bourdieu, e fundamentais para a "neutralidade axiológica”, nos termos de Weber.

Essas reflexões deixam as seguintes indagações: quem joga o jogo duplo? Aquele que compartilha de duas linguagens simbólicas assumidamente, ou aquele que joga em campos diversos sem ao menos "pagar pedágio" por isso? Se há jogo duplo, este poderia colocar em risco a autonomia do campo? Ou seja, a retradução deveria excluir o jogo duplo? 


\section{RELAÇÃO PARA COM O(S) CAMPO(S): O PACIENTE}

\subsection{O PACIENTE DENTRO DO(S) CAMPO(S)}

Pode-se pensar o paciente, mediante a perspectiva bourdieusiana, como sendo duplamente leigo. Ou seja, existe uma hierarquia dentro do hospital que pode fornecer importantes explicações. Nesse quadro, levando em consideração que os psiquiatras são experts em psiquiatria e as autoridades religiosas são experts em religião, os pacientes encontrar-se-iam na situação de duplamente leigos, destituídos de capital em dobro ${ }^{405}$. Porém, ao lado dessa constatação, é necessário lembrar o poder de decisão, a despeito da destituição de capital, que o paciente possui mediante os dois campos: ele pode optar por apenas uma ou pelas duas concomitantemente bem como por nenhuma das duas ofertas de salvação (saúde e redenção). Ou seja, essas são decisões que provêm, em última instância, do paciente. Ainda que seja sensato apontar para o aspecto não voluntário que pode estar contido em ambas as ofertas (tanto o tratamento psiquiátrico quanto 0 atendimento religioso podem vir de forma impositiva) é a demanda, o arbítrio dos pacientes/leigos que definirá a oferta.

Considera-se pertinente, portanto, independentemente do saber secreto do qual são privados, procurar verificar como os pacientes, definidores das ofertas, as encaram. Buscar saber se o que lhes é proporcionado, tanto em nível psiquiátrico quanto em nível religioso, vai ao encontro das suas necessidades e expectativas. Por isso, trata-se aqui somente - a despeito das diferentes posições em que os pacientes possam encontrar-se com relação aos psiquiatras e aos religiosos - dos posicionamento(s) deles em relação aos dois campos que o assediam.

\footnotetext{
${ }^{405} \mathrm{Se}$, por um lado, o psiquiatra e o ministro religioso assemelham-se no sentido de possuírem um saber secreto em relação aos pacientes-leigos. Por outro lado, o religioso é leigo em relação ao saber psiquiátrico e o psiquiatra em relação ao saber religioso. Ainda seguindo essa linha de raciocínio, o psiquiatra bi-posicionado ocuparia uma posição dominada em relação ao psiquiatra monoposicionado, ao mesmo tempo em que os voluntários ocupariam uma posição dominada em relação aos ministros religiosos. Há uma série de relações que podem ser visualizadas a partir das diferentes posições ocupadas (tanto de um campo em relação ao outro quanto no interior de um mesmo campo).
} 


\title{
8.1.1 O paciente dentro do campo psiquiátrico: a verdade dos pacientes sobre os psiquiatras
}

\begin{abstract}
O alienado ingressará no hospital, espaço recentemente medicalizado, defrontando-se com este novo personagem social que é o psiquiatra. Figura gigantesca e extensa, com ramificações em todo o espaço asilar, presente na figura de cada auxiliar-vigia, de cada enfermeiro, de cada janela, de cada grade, de cada muro. O alienista, como então era designado o psiquiatra, é uma figura onipotente por excelência, presente em todos os lugares e em todos os momentos, mesmo na sua ausência corpórea [...]. (A psiquiatria como discurso da moralidade, J. Birman ).
\end{abstract}

Busca-se compreender aqui, mediante os depoimentos, qual 0 posicionamento dos pacientes em relação à equipe médica. As críticas $^{406}$ dizem respeito: ao fato de os médicos não terem o alcance da doença ( $\mathrm{P} 14$ ); quererem resultados imediatos e acabarem ficando na superfície do problema (P14), o que faz com que muitas pessoas recebam alta sem estar realmente curadas (P14); a falta de atenção dos enfermeiros (P4); à sua frieza e mau humor (P5); o desprezo do médico quando o paciente propõe algum assunto diferente, como religião, por exemplo (P5); a falta de renovação das atividades, a saturação ocasionada por se fazer sempre as mesmas atividades (P8, P4) - "tem terapia ocupacional segunda e quarta-feira: segunda-feira você mexe com artesanato, essas coisas. Na quarta-feira é discussão de filme. É uma coisa que o povo tá saturado [...] Eu acho que chega uma hora aqui dentro que tudo cansa" (P8).

Uma crítica recorrente é quanto à falta de diálogo, de esclarecimentos no que concerne ao tratamento médico. Na sua autoavaliação sobre o posicionamento médico, P6 tem uma postura crítica revelando como os internos são desconsiderados enquanto sujeitos que buscam esclarecimentos sobre questões diretamente relacionadas à sua vida. Assim, ilustra tal questão ao mencionar a resposta que um médico dava aos pacientes quando estes indagavam qualquer

\footnotetext{
${ }^{406}$ Aqui apenas P7 e P5 acham que é bom o tratamento dispensado por médicos e enfermeiros, os quais são considerados "maravilhosos" (P5), "superpreocupados", praticamente amigos, quase uma família. Lembrando que P5 está internada pelo particular. Os outros pacientes não demonstram tal simpatia pelos profissionais.
} 
coisa: "Não choca, não choca, não vamos chocar!" (P6). Desse modo, a conclusão a que o depoente chega é a de que "os psiquiatras acham sempre que o doente está com mania e pergunta muito, mas quem pergunta quer saber" (P6). Ou seja, isso evidencia a caricaturização, feita pelo próprio médico, da figura do paciente que, antes de tudo, é enxergado como aquele que é estritamente movido pela patologia, não possuindo, assim, motivações próprias.

Quando se trata de delimitar as características que diferenciam os médicos dos outros detentores de conhecimentos e técnicas específicas, como por exemplo os engenheiros ou os técnicos, devese observar que a atividade dos médicos não se exerce diretamente sobre a doença, mas sobre o doente, que, diversamente do carro consertado pelo mecânico, não é um objeto inerte, mas pode saberse doente, saber alguma coisa sobre sua doença, desejar sarar e ter uma opinião sobre a maneira como se deve proceder para curá-lo. (BOLTANSKI, 2004, p. 13).

A postura autoritária levada a cabo pelo médico faz com que a relação que deveria ser de troca resuma-se a um discurso impositivo e vazio de significado para o paciente: "O 'colóquio singular' do médico e do doente reduz-se, assim, na maior parte das vezes, ao monólogo do médico, que, como um pesquisador, dirige e conduz a seu bel-prazer uma conversa aparentemente livre, cujo desenrolar obrigatório vai das perguntas que marcam seu início até às ordens que a terminam" (BOLTANSKI, 2004, p. 48). Assim, surgem reclamações quanto à falta de diálogo entre paciente e médico, o qual deveria fornecer melhores explicações sobre a enfermidade, esclarecer o tratamento medicamentoso e seus mecanismos (P6, P10), a razão dos procedimentos tomados: "Por exemplo, você não pode sair depois do almoço, tem que ficar sentado! Se eles explicassem melhor por que isso. A gente fica, mas parece que tá obrigado ali por motivo nenhum" (P10). Ocorre que, normalmente, os pacientes "não têm conhecimento das decisões quanto ao seu destino" (Goffman, 2005, p. 20) ${ }^{407}$. Entretanto, eles demandam por mais esclarecimentos, referem necessidade de serem ouvidos e de participarem do processo de decisão quanto aos procedimentos realizados. Eles querem opinar sobre as técnicas utilizadas para encaminhar o seu tratamento. A adesão a este último, ou ainda, a opção por esse tipo de oferta dependerá de como os psiquiatras

407 Segundo Goffman (2005, p. 20), tal exclusão propiciaria "à equipe dirigente uma base específica de distância e controle com relação aos internados". 
conseguirão articular os desejos dos pacientes e o rigor necessário ao tratamento médico. A simples imposição não garante uma adesão.

A atenção pode sofrer variação conforme a posição socioeconômica que possui o paciente, a qual pode determinar que tipo de atendimento será proporcionado, com mais ou menos cuidado: "O meu [médico] não é [frio] porque é particular [o tratamento]" (P5). Nessas circunstâncias, se o paciente não está pagando ele precisa "cair nas graças" (P5) dos profissionais, caso contrário ele não necessariamente será bem atendido. Ou seja, nota-se que a relação médicopaciente, além de muitos outros fatores, pode ser perpassada por questões de classe social, em função das quais os comportamentos desenrolam-se. Assim, ela ultrapassa a questão da posse do saber secreto, onde uns detêm o conhecimento e outros dele estão destituídos.

Longe de ser uma simples relação 'de homem para homem' ou, como quer a ideologia médica - que ensina a ver no doente apenas um ser abstrato e indiferenciado, sem levar em consideração, por exemplo, sua classe social ou sua religião - 'o encontro de uma consciência e de uma confiança', ou ainda, como descrevem alguns sociólogos, apenas a relação entre um especialista e um profano, a relação doente-médico é também sempre uma relação de classe, modificando-se a atitude do médico em função principalmente da classe social do doente. (BOLTANSKI, 2004, p. 40, 41, aspas do autor).

O tratamento dispensado aos pacientes pelos profissionais varia de uma tentativa de estarem abertos a aspectos simbólicos - "Eles respeitam. Pelo que eu já vi aqui, se você tem um ritual religioso é permitido" (E3) - a uma tendência de agir com dureza e prepotência. No primeiro caso, os aspectos culturais (os religiosos, por exemplo) são trazidos à tona, são respeitados (P5). No outro extremo, o da prepotência, a ausência de diálogo e as imposições ( $\mathrm{P} 11)$ são colocadas em prática ocasionando atritos: quando o médico duvida do paciente ou quando impõe restrições a ele (P10); pelo fato de o paciente não estar bem consigo mesmo (P12); relacionados à alimentação, o quanto se tem de $\operatorname{comer}^{408}$ (P14, P6, P8); quanto ao fato de se dar regalias a uns pacientes em detrimento dos outros (P14); quanto aos horários rígidos para tudo (P17) e ao excesso de regras do que pode e o que não

${ }^{408}$ Este tipo de questão relativa à alimentação provém mais da parte dos pacientes da enfermaria de transtornos alimentares. Em algumas situações, "um paciente que se recuse a alimentar-se pode sofrer a humilhação de alimentação forçada"(Goffman, 2005, p. 72). 
pode (P3). Neste último caso, como afirma Goffman (2005, p. 50), numa instituição total, frequentemente, há um conjunto de regras - compostas por prescrições e proibições - que especificarão "a austera rotina diária do internado" e nortearão a sua conduta.

É possível notar, nos relatos anteriores, o poder exercido pelo corpo médico. Esse poderio - também colocado em prática mediante poderes delegados a outros profissionais como enfermeiros, nutricionistas, etc. - coloca os pacientes sob o jugo do psiquiatra e do que ele define como sendo o melhor caminho a ser seguido: "A diferença principal entre o psiquiatra e o doente que está a sua frente não consiste no desequilíbrio entre saúde e doença, mas num desequilíbrio de poder. Uma das duas pessoas tem um poder maior, talvez um poder absoluto ${ }^{409}$, que lhe permite definir o papel da outra segundo sua terminologia" (BASAGLIA, 1985, p. 263). No par médico-paciente, que não é de hoje estudado, persistem os males do abuso de poder e da falta de humanização na relação. Infelizmente, esse quadro arrasador ainda é parte do cenário da medicina e das instituições de saúde atualmente. No caso em tela, ainda que de forma não tão violenta e desrespeitosa, os excessos não deixam de ocorrer.

\subsubsection{0 paciente dentro do campo religioso: a verdade dos pacientes sobre os religiosos}

Assim como no campo psiquiátrico, é necessário que se busque compreender aqui qual o posicionamento dos pacientes em relação aos religiosos (autoridades e voluntários) no sentido de apreender como eles encaram o trabalho religioso que lhes é proporcionado. Há críticas quanto à ausência dos religiosos (P3), o que não deixa de ser verdade, pois os próprios fazem alusão a isso. A experiência de atendimento, quando ocorre, é vista de forma positiva relacionada ao fato de dispensar a devida atenção e não forçar ninguém a nada (P8). As expectativas são: o religioso esclarecer dúvidas sobre a patologia e seu tratamento

\footnotetext{
${ }^{409}$ No entanto, esse tipo de comportamento autoritário é justificado pelos próprios pacientes como sendo necessário em certas circunstâncias, pois alguns internos são caracterizados como "bárbaros", "complicados" (P8) pessoas "terríveis" (P5), contra as quais é necessário empregar a força física (P5).
} 
$(\mathrm{P} 6)^{410}$; o religioso enquanto "alguém de fora"411 que pode "aconselhar, passar tranqüilidade, segurança" (P8), que possibilita "você se abrir, para você ficar mais leve" (P8). Em resumo: no religioso reside a esperança de satisfazer necessidades não saciadas pelo médico.

Do mesmo modo que os psiquiatras, os pacientes percebem a falta de diversidade no serviço religioso hospitalar: de um lado, considera-se interessante que haja outras religiões além da católica $(P 8, P 6, P 12, P 5)^{412}$, por outro lado, afirma-se não ser necessário, pois em todas as religiões "o caminho é um só, Deus" (P6). O primeiro posicionamento dá visibilidade - e ratifica o que já foi abordado pelos profissionais de saúde - à questão da diversidade religiosa dentro do hospital e a sua não consideração. Já o outro posicionamento traz à tona a questão do discurso de que "Deus é um só", ao mesmo tempo propiciador do convívio de práticas religiosas diversas e estratégia para a exclusão de outras denominações religiosas. O que o paciente quer, no fundo, dizer é que não é necessária uma diversidade de crenças, pois as poucas que estão ali são capazes de representar todas as demais. Ambos os posicionamentos, apesar de distintos nos seus pontos de vista, apontam para atribuição de valor à religião.

\subsubsection{Religião do paciente e para o paciente}

Ainda no que diz respeito aos pacientes na sua relação com o campo religioso, é necessário pensar sobre o universo religioso do paciente e as suas expectativas quanto ao atendimento proporcionado no IPQ e à religião de um modo geral. Em associação a essas reflexões, é importante considerar de que forma as expressões "religiosidade", "espiritualidade" aparecem na perspectiva desses sujeitos.

\footnotetext{
${ }^{410}$ Essa atitude, tão criticada pelos médicos e proibida pelas autoridades religiosas, aparece, na verdade, como uma demanda do paciente.

${ }^{411}$ A possibilidade de conversar com alguém de fora que não seja um profissional de saúde (P8) é uma demanda.

${ }^{412}$ Até mesmo para "poder testar" (P6) ou porque "tem gente de todas as religiões" (P12) e percebese, por exemplo, a falta de espaço para espíritas (P5).
} 


\section{- Religião do paciente}

O catolicismo desponta, em primeiro lugar, no conjunto das adesões. Ele está presente, de alguma forma, na vida da maior parte dos entrevistados (P3, P4, P6, P7, P12, P14, P15, P16, P17): seja como religião de origem (na qual se foi socializado) ${ }^{413}$, seja como religião de duplicidade/multiplicidade (o pertencimento a duas ou mais religiões na situação religiosa atual) ${ }^{414}$, seja como religião de retorno (retomada após período de afastamento). É comum, no caso da religião católica, um retorno após afastamento ${ }^{415}$. O catolicismo aqui se apresenta, o que usualmente é observado em outros estudos, como religião de socialização primária ${ }^{416}$, como religião da não prática, aquela que "é apenas nominal" (NEGRÃO, 2001, p. 26), não sendo valorizada "enquanto crença, rituais, eclesiologia" (IBIDEM). Também é recorrente a associação de duas religiões ao longo do percurso. Tal procedimento é comum na dinâmica do campo religioso brasileiro onde "as religiões, em qualquer dos três momentos que resumem os percursos individuais, podem ser exclusivas, dúplices ou multíplices" (IBIDEM).

Em segundo lugar, estão representados os evangélicos de características pentecostais (P1, P2, P11, P13). Em relação a estes, pode haver a rotatividade no interior do próprio tronco, onde tal atitude ocorre, provavelmente, devido à grande quantidade de igrejas protestantes, de modo que "o leque de formas diferenciadas de servir ao mesmo Deus é bem amplo, incluindo igrejas históricas, pentecostais

\footnotetext{
${ }^{413}$ Em pesquisa realizada em São Paulo - intitulada Refazendo Antigas e Urdindo novas tramas: trajetórias do sagrado - com o objetivo de analisar como os indivíduos movimentam-se no campo religioso, Negrão (2001) leva em conta "o agente e suas atitudes religiosas como algo dinâmico, em movimento", normalmente com uma trajetória religiosa que se resume em: "De onde veio, por onde passou e onde está ou quer chegar". Dessa maneira, o autor refere-se a três "lugares" religiosos: universo de origem (que pode ou não estar ligado ao percurso posterior do informante), universo intermediário (religião ou religiões por onde passou, transitou antes de chegar no "lugar" em que ele se encontra hoje), universo atual (assumido na pesquisa como "não fixo", por levar-se em conta o dinanismo do campo religioso).

${ }^{414}$ A pesquisa citada anteriormente trabalha a questão da duplicidade e da multiplicidade religiosa (referente à religião atual) levando em consideração os troncos religiosos diversos (estes são: católico; protestante; afro-brasileiro; espírita; outros).

${ }^{415}$ Tal situação pôde ser constatada em estudo realizado relacionando migração e mudança religiosa, onde foi possível perceber casos em que ocorre inicialmente uma fuga do catolicismo e mais tarde um retorno a este (normalmente não mais como religião exclusiva, mas associada à outra crença) (ASSUNÇÃO, 2004, p. 145).

${ }^{416}$ Não foi possível saber exatamente, pois não era o objetivo aqui, se havia exclusividade ou não na origem religiosa.
} 
tradicionais, neopentecostais e até adventistas" (NEGRÃO, 2001, p. 46). A mudança corriqueira no interior do campo evangélico está, em grande medida, relacionada

a abertura das vias de comunicação interdenominacional, a despeito das diferenças. Sustenta, ademais, o sentido comum da expressão genérica 'evangélico'. As pessoas encontram facilidade para passar de uma igreja para outra porque entendem que elas compartilham de uma mesma fé. (FERNANDES, 1998, p. 72).

Entretanto, esse ecumenismo protestante acaba por encobrir conflitos existentes no campo evangélico, no qual ocorrem dois tipos de atuação diversos: de um lado as neopentecostais, "como agências religiosas de resolução de problemas não solucionados ou não solucionáveis pelas agências seculares destinadas ao seu enfrentamento" (NEGRÃO, 2001, p. 50); de outro lado, as protestantes tradicionais com atuação voltada para o louvor e a prédica ético - doutrinária (IBIDEM).

Apenas dois casos de kardecistas (P5, P8), um da Igreja Messiânica Mundial (P9) e um sem religião. Semelhante constatação poderia dar respaldo à justificativa dos religiosos para o monopólio baseados no argumento de que o protestantismo e o catolicismo representam a maior parte da população brasileira. Esse argumento, entretanto, continua não sendo convincente. Isso, se em lugar de se pensar quantitativamente, passar-se a encarar a situação em termos do respeito necessário - não importando se há apenas uma pessoa de outra religião -, da garantia de participação de todos os que, de alguma forma, mais ou menos, representam não a totalidade, mas a singularidade dos sujeitos.

\section{- Religião para o paciente}

Há diferentes perspectivas quanto ao significado da religião. Ela pode ser vista - assim como consideram os psiquiatras - como esfera privada da vida, algo que diz respeito, única e exclusivamente, ao indivíduo. Nesse sentido, a religião "é uma coisa muito particular" (P1, P13), que "é só da pessoa" (P3) e que, por isso, pode-se não estar à vontade para compartilhar: "não me sentiria à vontade" (P12). 
Porém, a despeito do seu caráter confidencial, à religião podem ser conferidos os seguintes atributos: norteadora da vida, ajudadora nos momentos de crise (P3); fonte de explicação para as mazelas (P5) e para o que parece inexplicável (P5); doadora de força e esperança (P5, P8, P16, P6); algo em que se pode agarrar, que dá sustentação (P8, P10), conforto (P14), que tranquiliza, que ajuda a lidar com a depressão (P3, P12) e com a ideia de suicídio (P7); algo que pode proporcionar cura (P13) e que é o plano de salvação divina (P2). É importante advertir aqui que os psiquiatras fizeram tais considerações sobre o papel da religião na vida do paciente. Ou seja, estes profissionais, ainda que venham a se opor, parecem não estar de todo desinformados sobre os diferentes papéis que a religião pode desempenhar na vida dos pacientes.

De maneira similar ao que acreditam os psiquiatras, para alguns pacientes, mutatis mutandis, o que importa não é a religião, mas sim a fé. Descarta-se, nesse sentido, a importância da instituição ou do tipo de denominação, pois qualquer lugar, desde que conduza a Deus, deve ser levado em consideração. Assim, expressam-se os depoentes mediante afirmações como: "religião não é tão importante, o que importa mesmo é a fé" (P1); "tudo que leva a Deus é bom, não importa a religião da pessoa" (P5); "não precisa ir à igreja rezar, pode rezar em casa" (P8); "tem que ter algum credo, seja ele qual for" (P9). Há, por sua vez, um pessimismo e descrença em relação tanto a Deus - devido ao fato de se estar doente e sentir-se desamparado (P4) - quanto à Igreja em si - por ver "tantas coisas erradas" (P6), pessoas que usam a religião para cometer crimes sexuais, crimes financeiros (P6).

Os aspectos práticos da religião, os aspectos negativos e prejudiciais, os aspectos relacionados ao conflito religioso: todos são trazidos à tona. No primeiro caso ela manifesta-se enquanto agência prestadora de serviços para resolver questões pontuais (por exemplo, P7 toma as pílulas do frei Galvão para melhorar). No segundo caso, a religião é vista com o poder de cegar as pessoas, as quais ficam "bitoladas, fanáticas" (P8). No último aspecto, acredita-se que a religião faz com que as pessoas não estejam "abertas para outras coisas" (P8), tenham preconceito com relação às escolhas religiosas alheias e, assim, ao invés de ajudar pode impossibitar o diálogo entre os pacientes (P14). Nesse derradeiro caso, alertase para a possibilidade real de a religião vir a ser um campo de batalha em vez de ser uma ferramenta terapêutica. Isso pode ocorrer, ao fazer com que os pacientes 
fixem-se no conflito religioso e não no construtivo e enriquecedor diálogo na diferença.

\subsubsection{O espiritual e o psiquiátrico: qual a "verdade(ira)" demanda? ${ }^{417}$}

A relação com o campo psiquiátrico e com o campo religioso pode ser de aderência ou repúdio. As duas possibilidades são reais, pois quem define o tipo de demanda é o paciente, o fortalecimento ou o enfraquecimento da atuação, tanto do médico quanto do religioso, passa pelo desejo do paciente (que irá optar pelo que corresponde mais às suas necessidades). Isso se traduzirá como demanda. Segundo AR3 há situações a que o médico e o restante da equipe de saúde não terão acesso: "o lugar do sagrado" (AR3). Esse lugar o paciente só se permite dar a conhecer "a quem é portador de uma ordem, de uma coisa religiosa" (AR3). Por sua vez, M24 afirma que não são todos os pacientes que gostam e sentem necessidade de atendimento religioso. O depoente exemplifica a afirmação mediante o caso que presenciou de um voluntário que entregava "uns panfletinhos" na enfermaria. $O$ psiquiatra afirma que nem todos os pacientes gostavam: "Tinha paciente que se incomodava com esse senhor porque ele ficava falando, pregava e os pacientes não tinham como sair da enfermaria" $(\mathrm{M} 24)^{418}$. Ou seja, o atendimento religioso assim como pode ser reconfortante para uns pode ser invasivo para outros. A seguir, M22 apresenta um caso paradigmático de como os dois lados - psiquiatria e religião devem estar atentos quanto ao tipo de demanda apresentada pelos pacientes.

Tivemos um caso muito importante que foi na Santa Casa, de uma moça que estava em paralisia e a gente achava que era uma paralisia psicogênica, não neurológica. Nenhum médico conseguia fazer nada durante meses. A família trouxe um pastor. Todo mundo reclamou: "Ele não vai prejudicar/atrapalhar a gente?" Chegou um

\footnotetext{
417 Psiquiatras (2 bi-posicionados), enfermeiros (1 neutro) e religiosos (3 racionalizados, 5 "magicizados").

418 Ao mesmo tempo em que se acredita terem os pacientes o poder da escolha, os mesmos encontram-se numa situação de exposição, sem ter a possibilidade de fugir (já que estão "presos") ao contato com os religiosos que vão às enfermarias. Ou seja, é uma via de mão dupla: ao mesmo tempo, eles têm e não têm escolha.
} 
pastor com um cajado, barba, parecia uma figura bíblica e ele olhou para a moça: "Minha filha, levanta-te e anda". Ela saiu da cama e começou a andar. Ele falou aquilo que ela estava precisando. Ela estava com sentimentos de culpa [...] e o que a gente fazia era espetar agulha, remédio, etc... Precisava de alguém que: "Olha, Deus está do seu lado. Levanta, anda, caminha". Ele falou aquilo que a gente não conseguiu falar em meses. O que ela queria ouvir. Então, às vezes eu vejo isso: a religião dá o que a gente não está conseguindo. $\mathrm{E}$ principalmente hoje, como o médico está muito afastado dos pacientes... hoje os médicos, inclusive psiquiatras, conversam pouco com os pacientes. É uma pena. (M22).

Quando a demanda é religiosa e quando ela é por tratamento psiquiátrico e medicamentoso? Existiria, de fato, a demanda por um ou por outro? Em primeiro lugar, é necessário indagar se a internação foi requerida, foi voluntária e, depois, se existe realmente uma demanda religiosa. Sabe-se, por exemplo, que alguns pacientes sentem-se desconfortáveis com a visita de religiosos bem como se tem informação de pacientes que foram levados à internação por familiares que constataram o não enquadramento às regras sociais. Há de se perguntar se essas demandas são voluntárias ou não. No último caso, possivelmente, a oferta sobrepõe-se às necessidades reais do paciente. O fato é que com a diversidade de opções, religiosas ou não, a que o homem tem acesso, impossível estar-se preso a apenas uma delas. Em relação às opções religiosas é ainda mais marcante devido à miríade de religiões existentes ${ }^{419}$.

Se a religião/religiosidade é importante na vida do paciente, não só o serviço religioso deve estar disponível como o profissional de saúde deve procurar saber mais sobre o assunto, levá-lo em consideração (E9), acreditam alguns. Pode haver aquele paciente que tem religião e que, porventura, goste de falar sobre isso com o médico/enfermeiro (P8), essa realidade às vezes até se concretiza: tem paciente que é abordado nessas questões pelo profissional (P12, P11) e tem paciente que aborda a questão e é ouvido pelo profissional (P14). Entretanto, é importante alertar que, do mesmo modo em que há os que consideram importante o profissional saber qual a religião para "conhecer o que se passa na cabeça do paciente" (P10), há também casos de pacientes que não têm interesse na questão (E7) e que até podem sentirse incomodados.

\footnotetext{
${ }^{419} \mathrm{Em}$ face de tal realidade, até mesmo os que se empenham em centralizar o atendimento religioso, curvam-se à possibilidade futura de uma assistência religiosa à la carte (AR1). Esse modelo de serviço religioso previsto pelo entrevistado, e que parece tão avançado e moderno, é aquele que é colocado em prática pelos hospitais franceses (como abordado no quarto capítulo).
} 
Ou seja, é necessário certificar-se da real necessidade de entrar em tal questão. Além do que, à medida que se adentra nela, é imprescindível estar apto a abordá-la. Assim, o médico para conversar deve: entender de religião (VR2); estar preparado (VR6), conhecer (VR7). O paciente pode não gostar de ser abordado nessas questões pelo médico (P3) bem como, dependendo da abordagem, pode não se sentir à vontade (P1, P10). Associada a esta última questão, é necessário ter sensibilidade (VR5), ou seja, saber como fala, pois se corre o risco de, a despeito da boa intenção, propiciar um significado negativo à intervenção religiosa - "o paciente pensar: se o médico está falando pra mim de religiosidade é porque não tem mais jeito". (VR10).

Independentemente do aspecto religioso ou do aspecto psiquiátrico, a demanda é pelo diálogo, pela escuta. Como pode-se notar, mediante as falas de alguns entrevistados, o pedido é que se tenha "mais psicólogos para desabafar, pessoas para conversar" ( $\mathrm{P} 4, \mathrm{P} 1)$ ou que, por exemplo, tenha além do tratamento medicamentoso uma parte religiosa (P6). Uma depoente afirma que os colegas de enfermaria "são carentes, não têm com quem conversar" (P5), o que é confirmado por P8 quando diz: "Talvez eu ache que sinta necessidade de conversar por sentir falta de alguém [...], mas acho que se sente necessidade tem mais que conversar, mesmo. Tem que botar pra fora" (P8). Ou seja, prioritariamente, tanto psiquiatras quanto religiosos devem esforçar-se por proporcionar aos pacientes um contato no qual a comunicação seja o aspecto mais importante para o qual deverá convergir o restante das ações.

A necessidade do diálogo pode estar relacionada, acreditam alguns, a uma carência advinda do afastamento de seus entes queridos: "É todo mundo muito carente. Uma carência infinita aqui dentro. Pelo fato de os familiares não poderem vir visitar todos os dias eles ficam muito agradecidos. Às vezes você está passando no corredor, um te chama: 'Senhora, a senhora não vai vir aqui, não?'” $(V R 12)^{420}$. Talvez isso aconteça, pois a instituição hospitalar, ao interpor um grande número de intermediários entre o paciente e sua família e o médico - este figura intocável e invisível -, e ao restringir os contatos entre o doente e seus médicos, o doente e suas famílias, "aumenta a solidão e a ansiedade dos membros das classes baixas frente à doença e à medicina" (BOLTANSKI, 2004, p. 37).

${ }^{420}$ A referência, nesse caso, é aos pacientes do Instituto Central (IC) do HCFMUSP. 


\title{
8.2 NECESSIDADES, DESEJOS, PERDA DE IDENTIDADE ${ }^{421}$
}

\begin{abstract}
Ninguém compreende o que quero, ninguém deseja penetrar e sentir; passo por doido, tolo, maníaco e a vida se vai fazendo inexoravelmente com a sua brutalidade e fealdade. (O triste fim de Policarpo Quaresma, Lima Barreto).
\end{abstract}

Os pacientes, teoricamente, devem ser respeitados dentro do hospital. $\mathrm{Na}$ prática isso pode ou não acontecer. Na relação com os pacientes, tanto os religiosos podem extrapolar no que lhes é permitido - ao terem uma atuação proselitista ou ao imporem uma crença, por exemplo - como os psiquiatras podem, de seu lado, não estarem abertos a ouvir quais são as suas necessidades, impondo-Ihes apenas um tratamento medicamentoso stricto sensu. Nessa direção, ocorre um desrespeito em relação à figura dos pacientes que se vêem privados de escuta. Assim, ao analisar a situação do paciente internado num hospital psiquiátrico, Basaglia (1985, p. 107, 108) afirma tratar-se de "um homem sem direitos, submetido ao poder da instituição, à mercê, portanto, dos delegados da sociedade (os médicos) que o afastou e excluiu".

Os psiquiatras, por um lado, podem não dar "abertura" para conversar sobre temas externos ao tratamento médico, e pode acontecer, por outro lado, de os pacientes não encararem "com bons olhos" falar de questões pessoais (como religião, por exemplo) com os psiquiatras. O primeiro caso pode ser devido à falta de flexibilidade dos profissionais de saúde para tratar de questões do âmbito simbólico; já o segundo caso pode ser consequência de os pacientes não possuírem uma tradição em relação a isso, um habitus que os mobilize nesse sentido. Há os profissionais abertos a esse tipo de comunicação (M2), que acreditam que quando o psiquiatra mostra-se acessível - não necessariamente o profissional precisa ter uma religião -, ele "consegue criar um vínculo muito melhor com o paciente" (M1), o que pode ser bom para ambas as partes. Ao contrário, se o paciente "não vê abertura" no sentido do médico evidenciar que é "um tema válido" (M1), que é respeitado - ele

421 Psiquiatras (2 mono-posicionados, 4 bi-posicionados, 8 neutros), enfermeiros (9 neutros) e religiosos (4 racionalizados, 4 "magicizados"). 
não irá falar. Isso poderá ser faltoso para o tratamento, pois é possível deixar de "tocar num aspecto importante na vida do paciente"422 (M1) - algum conflito ou dificuldade que ele pode estar tendo em função da religião, bem como se deixa de perceber que é "um recurso que ele pode estar buscando na religião" (M1).

Nos contatos com os diversos campos, os pacientes são os que apresentam necessidades a serem respondidas, vontades a serem satisfeitas. Eles, normalmente, vivenciam uma perda de identidade, a partir do momento em que se veem destituídos de seus objetos pessoais, da companhia daqueles que ama, do poder de ir e vir, dentre outras coisas. Nesse sentido, a religião pode ser uma forma - dentre os possíveis universos simbólicos - de resgatar a identidade perdida, de valorizar a singularidade dos sujeitos adoecidos. Isso pode acontecer a partir do momento em que, num ambiente onde os pacientes são números, o religioso pergunta o nome e engata uma conversa: "A gente pergunta, delicadamente: 'Qual é o seu nome?' Eles são muito mais conhecidos pelo número do quarto, do leito" (VR4). A entrada no hospital dá-se mediante total perda de identidade, onde nada mais pertence ao sujeito, nem a posse de si mesmo - "entrou no hospital acaba a identidade: é a roupa que o hospital dá, empresta. Tudo é emprestado, até a identidade. Quando não é nominado pela doença também" (VR4). A despeito da necessidade que o indivíduo tem de um “'estojo de identidade' para o controle de sua aparência pessoal" (GOFFMAN, 2005, p. 28, aspas do autor), ao ser admitido numa instituição total ele é "despido de sua aparência usual, bem como dos equipamentos e serviços com os quais a mantém" (IBIDEM), provocando dessa maneira a sua desfiguração pessoal.

O doente é uma situação muito atípica do indivíduo. Aqui ele está fragilizado, longe do ambiente dele. Ele está sendo submetido a uma coisa que muitas das vezes ele não quer. Esse afastamento. Então, ele aceita as coisas. Ainda que haja direitos estabelecidos para o doente, ele não só desconhece como ele nem quer se fazer valer dessas coisas. Ele quer aquilo que está sendo oferecido. $E$ quando uma coisa muito terna é oferecida eles gostam muito. (AR3).

\footnotetext{
${ }^{422}$ Segundo M1, para fazer esse tipo de abordagem o médico não precisa compartilhar a religião do paciente ou ser religioso: "tem que entender o mundo do paciente, não importa se eu compartilho ou não daquele mundo. [...] A gente sempre diz que a intervenção espiritual é para o paciente, a abordagem da religiosidade deve ser centrada no paciente, não no médico. Então, tem que ver quais são as necessidades do paciente, a religiosidade do paciente, como aquilo influencia a vida dele. É isso o que me interessa e não a minha religiosidade. Acho que esse é o grande desafio" (M1).
} 
Como já havia lembrado Goffman, a instituição total ${ }^{423}$ é um espaço de mortificação do eu no sentido de que nela, além do sujeito perder sua identidade, pode ser vítima de "uma série de rebaixamentos, degradações, humilhações e profanações do eu. Este é sistematicamente, embora muitas vezes não intencionalmente, mortificado" (GOFFMAN, 2005, p. 24). Supostamente considerado incapaz para saber o que é melhor, o "doente mental" recebe cuidados que muitas vezes Ihe são impostos contra sua vontade (SZASZ, 1978, p. 15). Por isso, qualquer oferta, seja ela religiosa ou psiquiátrica, que se pretenda humanizadora, deve levar em conta a vontade dos pacientes ${ }^{424}$. Ou seja, independente do tipo de prática de execução, toda ação psiquiátrica que se queira legítima e justa deve delimitar-se a "responder à solicitação que Ihe fazem os indivíduos" (COSTA, 2007, p. 25, destaque do autor).

O paciente tratado como um número, como algo que necessita ser classificado e identificado é resultado, lembra Foucault (1979), "do duplo nascimento do hospital pelas técnicas de poder disciplinar e médica de intervenção sobre o meio". Estas possuem como uma de suas características a "organização de um sistema de registro permanente e, na medida do possível, exaustivo, do que acontece". Dentre as possíveis técnicas de identificação: "Amarra-se no punho do doente uma pequena etiqueta que permitirá distingui-lo mesmo se vier a morrer. Aparece em cima do leito a ficha com o nome e a doença do paciente. Aparece, também, uma série de registros que acumulam e transmitem informações [...]" (FOUCAULT, 1979, p. 110). Este sujeito é o mesmo que deve assumir o papel de doente e a passividade que a ele está associada (COOPER, 1989, p. 45).

O correlato do disciplinamento médico do hospital contemporâneo, para o doente internado, é o surgimento do paradigma de "paciente", ao qual ele deve aceder para que se the retornem os virtuais benefícios da intervenção médico-hospitalar. Paciente: sofredor resignado, manso, vítima, doente, aquele que recebe a ação praticada por um agente. [...] Logo ao ingressar no hospital, o doente que se dispõe a ser "paciente" é convocado à supressão instantânea

\footnotetext{
423 "Uma instituição total pode ser definida como um local de residência e trabalho onde um grande número de indivíduos com situação semelhante, separados da sociedade mais ampla por considerável período de tempo, leva uma vida fechada e formalmente administrada" (GOFFMAN, 2005, p. 11). Analisando o IPQ enquanto instituição total, uma variável possível de verificação seria o tipo de dependência do paciente com relação à instituição (por exemplo, até onde iriam as limitações, proibições lá dentro relativas ao controle de saída, aos horários, etc). Nesse caso, a variável seria o tipo de enquadramento, de horário, de estruturação do tempo e do espaço.

${ }^{424}$ Há o caso excepcional de M13 que ora com os pacientes se eles quiserem.
} 
e voluntária de sua intimidade. (ANTUNES, 1991, p. 163, aspas do autor).

Um exemplo para ilustrar essa questão é o caso de P3 ao fazer referência ao psiquiatra que a atende: "Ele é rigoroso. Em primeiro lugar você viu que eu pedi pra você ir falar com ele. Que qualquer coisa ele me chama atenção. É o jeito dele. Ele é ótima pessoa" (P3). A depoente, que parece bem independente ao longo de suas falas na entrevista, assume um papel de submissão, na ocasião da presença do médico, para garantir a boa convivência com este. O relacionamento pode dar-se tal qual lembra Goffman (2002, p. 26) ao descrever o papel que o indivíduo representa no modelo interacional. Aí ele fala da crença no papel desempenhado. Segundo o autor, podem ocorrer duas formas de atuação: a do cínico e a do "sincero". Na primeira, o indivíduo "não crê em sua própria atuação e não se interessa em última análise pelo que seu público acredita", na segunda, os indivíduos "acreditam na impressão criada por sua representação". Ao enganar um público, o indivíduo cínico o faz não por interesse ou lucro próprios, mas pelo que ele considera ser o bem para esse público, o qual, por sua vez, não lhe permitirá ser sincero (GOFFMAN, 2002, p. 26). Em alguns casos, conforme sugere o comportamento "cínico", por exemplo, "os pacientes bondosos nos hospitais de doenças mentais fingirão às vezes sintomas estranhos para que as enfermeiras alunas não tenham de enfrentar um desempenho desapontadoramente sadio" (IBIDEM). Fatos como este, ou como aqueles constatados por Goffman (2002, p. 26) em que pacientes aprendem a não manifestar sintomas para receberem alta, podem ser corriqueiros. A representação, colocada em prática pelo paciente no ambiente hospitalar relaciona-se, por sua vez, ao preconceito e à insensibilidade colocados em prática pelos profissionais de saúde.

Alguns profissionais de saúde e alguns religiosos posicionam-se em relação ao tratamento corriqueiramente dispensado aos internos. Fazem o mea-culpa no sentido de fazer notar a importância do respeito pelo paciente ${ }^{425}$ e da ajuda efetiva que se pode obter do contato com a religião.

\footnotetext{
${ }^{425}$ Ainda que sejam feitas ressalvas quanto à necessidade real de estar aberto a outras temáticas e ao fato de a demanda dever partir do paciente.
} 
As considerações giram em torno dos seguintes eixos: o respeito ${ }^{426}$; o interesse ${ }^{427}$; a identificação de demandas ${ }^{428}$. Os pacientes, acima de tudo, não podem ser motivo de disputa entre médicos e religiosos e muito menos entre estes: "O doente não pode ser disputado, não pode ser objeto da nossa preferência ou da nossa maneira de entender" (AR3). Ao contrário, eles devem ser respeitados, jamais serem desconsiderados nos seus gostos e escolhas (E7). "Eu, particularmente, faço e procuro orientar as pessoas a entrar pela porta que o doente abre". (AR1).

A gente respeita, acima de tudo, a opinião, o gosto. São seres humanos como a gente. Se a gente pode optar, porque os pacientes não? [...] Tivemos uma paciente judia. Então ela tinha todo o ritual às sextas-feiras, os feriados são diferentes, o que ela pode ou não pode comer. Eu acho isso muito interessante: você saber e o fato de você poder respeitar. Então, todo mundo se sensibilizou em saber um pouco mais sobre a religião da menina para a gente poder estar respeitando. $(E 7)^{429}$.

O lugar ocupado pelos pacientes, diferentemente daquele ocupado pelos religiosos e pelos psiquiatras, não tem características de campo (protegido, demarcado), o qual possui uma história institucionalizada; ao contrário, existe como um espaço com características de campo, mas não o é. Diversamente, é um espaço interseccional onde a religião encontra a psiquiatria: de um lado, é um espaço em que os médicos têm de lidar com a religião (é difícil não lidar com ela já que há demanda por parte dos pacientes), de outro lado, é um espaço onde os religiosos têm de lidar com a psiquiatria reproduzindo o seu discurso médico-científico. Por isso, o lugar simbólico onde ocorre a conjugação entre psiquiatras e religiosos,

\footnotetext{
${ }^{426}$ Necessário "deixar o paciente se apresentar do jeito que ele quiser se apresentar" (M15)/ Abordar aspectos religiosos é importante, mas "respeitando a escolha do paciente" (M19)/ Respeitar a opinião do paciente, considerar o que é valor para ele (M24)/ Respeitar o paciente e as suas crenças (E1, E2, E5, E9)/ Evitar dar opiniões (E4, VR10)/ Não influenciar em nada apenas ouvir (E6)/ "A gente respeita o direito do paciente, a vontade dele" (E8)/ Não podemos invadir a privacidade (E10)/ Mais ouvir do que falar (VR1, VR4, VR9, VR10)/ Respeitar o direito do outro (VR9, VR13)/ "A critério do paciente" (VR10).

${ }_{27}$ Estar atento a outros aspectos da vida do paciente faz com que ele tenha a sensação de que o médico se interessa por ele (M14)/ O médico deve ser mais interessado pela vida do paciente (M16, M17).

${ }_{428}$ É importante aceitar o paciente da forma como ele se apresenta (M2, M15)/ Se a religião é importante no referencial pessoal do indivíduo deve ser levada em conta (M4)/ Tudo deve passar pelo desejo do paciente, sem imposições (M5)/ Tem de respeitar a crença do paciente e usá-la para ajudar (M7)/ O serviço religioso deve ser somente a pedido do paciente (M10)/ Se for a pedido do paciente (VR7)/ Proporcionar a fala ao paciente, deixar ele à vontade para levantar temas, identificar "qual é o pão que ele está precisando" (M22)/ Muitas vezes o médico não tem tempo, mas a religião pode ser importante (M3).

${ }_{429}$ Entretanto, como visto em outro momento, os psiquiatras mostram-se irritados com esse tipo de demanda que interfere no tratamento (M22) e consome recursos do hospital (M10).
} 
considera-se pertinente denominá-lo "espaço", no qual a figura do paciente é o que justifica a presença de ambos os domínios e seus especialistas.

O doente, aqui dentro do hospital, eu vejo como uma presença sagrada que é a razão de toda a nossa presença aqui dentro. Ele tem que ser... não digo venerado não, mas reverenciado de todas as maneiras. Que haja, ali, um respeito tão sublime por ele. (AR3).

Ao contrário do interacionismo simbólico, para o qual tudo se desenrola no momento da interação - o que faz com que os estudiosos ligados a essa linha de pensamento acreditem sobremaneira no poder da interação -, a visão bourdieusiana (adotada ao longo deste estudo) interessa-se pouco pela interação, pensa que o essencial, antes de qualquer coisa, é a posição ${ }^{430}$. Desse modo, ainda que a proposta do interacionismo simbólico seja relevante para o entendimento das relações sociais, ateve-se aqui ao contexto das posições e das tomadas de posição, não ocorrendo, portanto, a observação direta de interação, seja entre psiquiatras e pacientes, seja entre estes e os religiosos no sentido do face a face ${ }^{431}$ preconizado por Goffman (2002).

No interior de uma instituição total, para além das interações que acontecem, é interessante notar como faz diferença a disparidade de capital entre os especialistas e entre estes e os internos - seja capital econômico, capital cultural ou capital religioso. Segundo Bourdieu (1983a), por trás dos sujeitos da interação há toda a sua história pessoal, a sua posição social. Nas palavras do autor, "[...] não se pode reduzir as relações objetivas que são constitutivas do campo ao conjunto das interações, no sentido do interacionismo, isto é, ao conjunto das estratégias que, na realidade, ele determina" (BOURDIEU, 1983a). Nesse sentido, é possível perceber o habitus na interação, no sentido de que para Bourdieu quando os indivíduos encontram-se há toda a história deles por trás daquele momento do encontro, do face a face. É nisso que reside a ação social para a qual se deve prestar atenção,

\footnotetext{
${ }^{430}$ Segundo Ortiz (1983, p. 13, 14, aspas do autor), em Bourdieu, "a comunicação se dá enquanto 'interação socialmente estruturada', isto é, os agentes da 'fala' entram em comunicação num campo onde as posições sociais já se encontram objetivamente estruturadas [...]. Afirmar, portanto, que a interação se dá de forma socialmente estruturada implica negar a apreensão do mundo como intersubjetividade, como o fazem os interacionistas simbólicos".

${ }^{431} \mathrm{O}$ interacionismo simbólico utiliza a linguagem teatral para pensar o modelo do face a face: "[...] a interação (isto é, interação face a face) pode ser definida, em linhas gerais, como a influência recíproca dos indivíduos sobre as ações uns dos outros, quando em presença física imediata". (GOFFMAN, 2002, p. 23).
} 
caso contrário, corre-se o risco de inventar um espectador teórico, descolado do seu contexto social. Entretanto, ao pensar detidamente sobre essas duas perspectivas, faz-se necessário considerar a possibilidade de complementação entre ambas, já que as posicões sociais são importantes até para entender como se dá a interação.

Com isso, se quer advertir que, ainda que não se tenha - como faz a maior parte dos estudos que tratam de instituição total - investido na questão da interação em si, esta foi posta em cotejo (ainda que timidamente) em relação à proposta bourdieusiana. Assim procedendo, procurou-se ocupar o "lugar geométrico" (defendido por Bourdieu), onde as teorias não têm status de exclusividade, podendo ser de alguma forma combinadas, utilizadas como ferramentas para um objetivo maior: o entendimento do mundo social e os seus imponderáveis. 


\section{CONSIDERAÇÕES FINAIS}

Refuta-se a hipótese inicial de que o contato entre campo psiquiátrico e campo religioso leva a perda de identidade, à descaracterização do primeiro. Considera-se, ao contrário, a retradução como fonte de explicação do sucesso de contato entre os dois campos. Lembrando que a retradução não implica a perda das características essenciais, mas um tipo de acomodação sabiamente realizada para impedir - no que concerne aos distintos campos sociais - tanto a perda das propriedades nativas quanto o engajamento em conflitos desnecessários. Ou seja, além de se tratar de um sinal de autonomia, a retradução propicia a comunicação entre os campos. Assim, os pedidos que vêm do campo religioso são retraduzidos na psiquiatria. Possivelmente, isso aconteça porque - ao ter "ouvidos musicais" para as angústias, os sofrimentos humanos - a religião ajuda na recuperação dos pacientes, o que não é ignorado por alguns psiquiatras.

Essa retradução às avessas - do campo dominante em relação ao campo dominado - é necessária, pois a superioridade do campo psiquiátrico ainda que lhe garanta, sem ameaças, a predominância no espaço hospitalar; não the assegura a supremacia na mente dos sujeitos, os quais podem dar guarida a diferentes universos simbólicos (inclusive o religioso). Se a psiquiatria quer, de fato, ter atuação na vida dos pacientes, ela deverá dialogar com outros sistemas, dar espaço a algo que lhe é anterior: o poder dos símbolos e das diferentes representações na vida humana. Confrontar-se com o universo religioso não será conveniente, pois, numa sociedade majoritariamente religiosa como a brasileira, semelhante postura ressoa, até mesmo, como um desatino.

A retradução utilizada para pensar a relação entre os campos é um caminho razoável, pois diz muito de um dinamismo próprio ao campo, no qual estão inseridos conflitos internos e pressões externas. Portanto, possibilita uma reflexão enriquecedora nesse sentido. O campo psiquiátrico retraduz o campo religioso, no sentido de que aquele reelabora as demandas externas deste último, fato este que é diferente de dizer que o primeiro está a serviço do segundo. Ou seja, isso não significa um mecanismo de redução de um campo ao outro. Retradução é a capacidade de transformar tudo em uma única forma de capital, no caso, seria a 
forma de capital do campo ao qual se pertence; ou seja, retraduzir seria como fazer o câmbio de moedas ${ }^{432}$.

A retradução é resultado de posicionamentos específicos no(s) campo(s). As posturas são, normalmente, de busca por um "lugar" onde não haja desrespeito aos preceitos médicos nem tampouco o rechaço das questões religiosas/espirituais. Um "lugar" e uma linguagem a partir dos quais possa ser estabelecida uma comunicação que não comprometa o rigor necessário.

Como foi possível perceber, os diferentes posicionamentos de psiquiatras (mono-posicionado, bi-posicionado, neutro/ambíguo) e religiosos ("magicizado" e racionalizado) apareceram ao longo da tese em questões polêmicas - e nos diferentes temas a elas relacionados - relativas à ocupação de um mesmo espaço físico e simbólico e ilustraram as relações no interior dos campos e entre eles. Os posicionamentos dos psiquiatras disseram muito do seu ponto de vista tanto sobre a presença religiosa dentro do hospital quanto sobre as religiões de um modo geral e a relação destas com as patologias psiquiátricas. Os posicionamentos dos religiosos, por sua vez, demonstraram o grau de aceitação e de aderência aos preceitos médico-psiquiátricos e a atuação conforme ou não ao mandamento dos cientistas. Nesse contexto, a abordagem de questões como normal/patológico fez todo sentido porque foi, principalmente, em torno desse par de conceitos que se baseou e justificou-se o conflito. Ou seja, isso teve relação com o posicionamento no campo: os psiquiatras se contrapuseram ao contato com a perspectiva religiosa (o que não significa necessariamente a oposição à presença religiosa) principalmente em pontos de vista sobre a possibilidade do delírio místico/religioso. Em outras questões, como reestruturação da vida, eles ficaram de acordo.

Já o posicionamento de embate no interior dos campos aconteceu: em relação aos psiquiatras, mediante a questão do biologicismo versus humanismo; no que concerne aos religiosos, na questão do monopólio religioso versus pluralismo religioso. Todos esses pontos perpassaram conflitos e possíveis retraduções no âmbito da relação entre os campos. Quando os psiquiatras afirmavam a necessidade de valorizar o aspecto humano dos pacientes, eles retraduziam

${ }^{432}$ Em analogia ao mercado financeiro, segundo François Bonvin (informação verbal), um bom exemplo para pensar a retradução é o estrangeiro que traz suas moedas que não são válidas e as troca pela moeda nacional. Em dado momento, ocorrerá também de o mercado ficar misturado e ele poder usar as duas moedas ao mesmo tempo. 
demandas externas. Pode-se interpretar isso como pressão externa ao campo (vinda dos pacientes, dos religiosos), no sentido de pensar toda a problemática em termos de posições diferentes, de uma distribuição desigual de capital entre os campos e no interior destes. Esse é um caminho possível. Entretanto, esse movimento pode ser cotejado em relação a um possível esforço de manutenção da autonomia do campo.

É possível concluir, a partir da realidade apresentada pelo Instituto de Psiquiatria do HCFMUSP, com a superioridade (esta relacionada à detenção de um capital que vale naquele espaço específico) dos psiquiatras em relação aos religiosos: existe uma dominação do campo psiquiátrico sobre o campo religioso que passa por questões de reconhecimento, detenção de um saber específico. A variável de verificação está presente tanto na fala dos psiquiatras ao afirmarem que a religião é um sintoma da doença quanto na fala dos religiosos ao afirmarem - mesmo fazendo ressalvas - que o psiquiatra é mais importante, a cura científica é prioritária. Nos dois casos, fica claro tratar-se da dominação do campo psiquiátrico sobre o campo religioso. Dominação esta, que fique claro, bem reconhecida do ponto de vista da doença - que é o que conta naquele espaço específico - não do ponto de vista dos fins últimos da existência.

Se o campo psiquiátrico é predominante, qual o sentido de se falar em retradução? Apesar da dominação exercida pelo referido campo, existem fatores que justificam a necessidade da retradução. Um deles é relativo ao fato da presença salvaguardada dos religiosos no espaço hospitalar (eles possuem garantias constitucionais $^{433}$ para tal), o outro está associado ao fato de a escolha por uma ou outra oferta (religiosa ou psiquiátrica) ser arbitrada pelo paciente. Os religiosos não serão uma ameaça direta para os psiquiatras, isso somente poderá acontecer mediante os pedidos dos pacientes. A leitura bourdieusiana de Weber mostra que o arbítrio vem dos leigos e de suas necessidades (que podem ser por legitimação ou por salvação). Desse modo, a partir do momento em que os pacientes optam por um tipo de serviço (médico ou religioso), o outro corre o risco de desaparecer; o que faz com que aquele que perdeu espaço realize um trabalho de reintegração (a retradução seria isso). A exemplo do campo religioso: nos momentos em que não é possível eliminar o profeta, abre-se-lhe certo espaço dentro do campo e integra-se

${ }^{433}$ É o que consta na lei $n^{\circ}$ 9.982, de 14 de julho de 2000, que dispõe sobre a prestação de assistência religiosa nas entidades hospitalares públicas e privadas, bem como nos estabelecimentos prisionais civis e militares. 
as mensagens dele ao religioso instituído (nesta situação particular, o que ocorre é uma reintrodução escondida, camuflada de aspectos divergentes que compõem o campo). O que foi apontado no capítulo sexto, em relação aos agentes religiosos, pode ser aplicado aos profissionais da área de saúde: não existe uma fronteira administrativa, a fronteira entre o universo médico e o universo religioso é apenas simbólica: se os pacientes querem saúde, alívio do sofrimento físico ou emocional eles escolhem um ou outro grupo de especialistas. Aquele que não é escolhido percebe que o seu produto está em baixa ou está fadado a desaparecer, então retraduz.

As diferenças determinantes das tomadas de posição estão relacionadas a diferenças sociais e de percurso, ao habitus dos sujeitos. O interessante de verificar nesse espaço é o encontro de pessoas que são portadoras ou que são representantes de um tipo de relação, um tipo de habitus com a ciência ou com a religião e como elas interagem. A presença religiosa no IPQ, apesar de residual, é suficiente para colocar lado a lado diferentes perspectivas bem como a plasticidade de grande parte de religiosos e médicos é responsável por tentativas de trocas.

Como foi possível observar ao longo deste trabalho, em alguns casos, a depender dos agentes, um diálogo entre ciência e religião é efetuado. Os sujeitos não são de todo reféns das regras do campo ao qual pertencem, eles não são inertes e passivos. Ao contrário, há mobilização por parte deles a partir do momento em que, de um lado, falam linguagens científicas e religiosas ao mesmo tempo (psiquiatras e religiosos) e, de outro lado, utilizam concomitantemente recursos científicos e religiosos (os pacientes). Eles não obedecem a regras literalmente. De forma diversa, usam estratégias, não deixando nem por isso de fazer sempre o que o jogo do seu espaço específico requer. Existe um número de possibilidades em cada campo - fato este que já descarta a afirmação de que o habitus faz com que se execute sempre a mesma ação - e os agentes (sejam eles psiquiatras ou religiosos) escolhem, dentre um número de possibilidades, as situações mais favoráveis (quase instintivamente).

Dois modelos de escolha. Primeiramente, na relação dentro do campo temse, de um lado, a escolha pelo polo mais organicista/biologicista ou pelo mais humanista (no caso dos psiquiatras) e, de outro lado, a escolha pela postura mais monopolista ou pela mais pluralista (no caso dos religiosos). Em segundo lugar, na 
relação entre os campos, há, de um lado, o posicionamento mais favorável à religião (bi-posicionado, neutro) ou o menos favorável à religião (mono-posiconado), e há, de outro lado, o posicionamento racionalizado ou o "magicizado" (no caso dos religiosos). O desajuste na linguagem interna e externa aos campos evidencia que a definição dos objetivos de cada qual está pautada em idiomas diversos que giram em torno de posições também distintas. Seja no que diz respeito à disputa entre os especialistas de um mesmo campo ou entre especialistas de campos diversos, todos lutam porque há interesses.

Os dois modelos de posicionamentos, tanto internos quanto externos, podem ser analisados enquanto opções por dialetos - ainda que não seja possível afirmar que conscientemente escolhidos - dentro de um contexto de possibilidades. O porquê da escolha de um e não de outro (ou dos dois) é algo que tem a ver com um sentido prático - que foi incorporado pelos sujeitos - para o qual não se tem condições de impingir uma ação reflexiva ou não reflexiva. As estruturas objetivas interiorizadas de maneira prática, não conscientes - no campo religioso e no campo psiquiátrico - é que colocam esses sujeitos em conexão com o seu respectivo campo e em desajuste com a linguagem de outros campos. Algo que eles carregam na própria pele e que não precisam sequer pensar para colocar em prática, é quase "automático". Entretanto, este quase automatismo dá liberdade para improvisos, estratégias, graças às quais modos de agir e pensar, cunhados no próprio corpo ao longo do tempo, vem a se constituir de forma diversa sem que com isso o investimento no jogo - necessário a cada campo - seja deixado de lado.

O espaço de possíveis - que segundo Bourdieu "transcende os agentes singulares" - de psiquiatras e religiosos faz com que estejam conectados uns com os outros e, ainda que não diretamente, façam referência uns aos outros. Assim, por exemplo, os psiquiatras bi-posicionados e neutros, em relação ao seu espaço de possíveis (uma medicina organicista, biologicista, outra humanista), procuram ocupar um "lugar geométrico", que possibilite a contemplação de uma variedade de aspectos constitutivos da medicina em geral, não se fechando em um ou outro modelo. Os religiosos racionalizados ocupam um lugar limitado, de adesão aos aspectos intelectualizados da proposta religiosa; os religiosos "magicizados", estes sim, ocupam um "lugar geométrico", que abrange tanto os aspectos "mágicos" quanto os religiosos, eles transitam entre as possibilidades. 
O modelo organicista/biologicista ou o humanista, o modelo racionalizado ou o "magicizado", sob a perspectiva do habitus, é algo que foi interiorizado, que foi incorporado como uma disposição. É aquele mecanismo do qual o indivíduo não tem consciência de ser portador. Entretanto, no habitus estão presentes tanto os condicionamentos sociais quanto a liberdade no comportamento dos atores. Por isso, por mais que pareça impertinente, é necessário afirmar que os psiquiatras e os religiosos têm escolha de fazer parte ou não desse sistema, não há uma imposição, mas uma identificação com esta ou aquela mentalidade. O modelo organicistabiologicista há muito arraigado gera, pois, a necessidade nos agentes (que o carregam na pele). Mesmo aqueles que contestam tal modelo, que pretendem uma mudança radical, não o rechaçam de todo, curvam-se à sua importância e ao jogo que é jogado no seu campo (condição para o seu funcionamento). Isso quer dizer: os agentes que fazem uma inflexão nos jogos do campo possuem o comprometimento total com ele, ao contrário do que poderia se pensar. Por isso mesmo, estar atento aos aspectos culturais/religiosos não impede a predominância do modelo organicista-biologicista. Em outras palavras, não coloca em risco a autonomia do campo. Talvez o que se chama, em alguns momentos, de fluidez ou de plasticidade - ao perceber a movimentação dos agentes de um a outro polo não é senão a busca pelo novo sem o total desenlace com o antigo, com o que está interiorizado. As novas escolhas realizadas fazem notar o poder de movimentação dos agentes, mas o retorno a estruturas antigas mostra o quanto o habitus é potente e está sempre presente nas mentalidades.

A maior verdade dos psiquiatras sobre a religião é em relação ao fato de os quadros psiquiátricos envolverem temas religiosos. A maior verdade dos religiosos é que, no fundo, o paciente pode curar-se apesar do médico. Por um lado, vê-se um campo enquanto campo de forças e campo de lutas, que tem na retradução tanto o seu marcador de autonomia quanto a sua característica acomodativa. Por outro lado, percebe-se que as ofertas não podem, elas mesmas, se sobrepor ao agirem lado a lado; entretanto as demandas, estas sim, têm possibilidade de serem concomitantes (não concorrentes). Na percepção do psiquiatra ou do religioso, uma pode ser opositora da outra, para o paciente, uma reforça a outra.

O conflito ou a retradução entre psiquiatras e religiosos passa pelo paciente (lugar de reflexão), motivo das disputas. O fato de se dar sentido religioso a 
questões psiquiátricas ou, o contrário, dar sentido médico a questões religiosas/espirituais visualiza o desrespeito e despreparo dos dois lados. O contrário disso pode ser percebido na retradução, onde os pedidos realizados nos dois campos são filtrados, refratados. O fato é que psiquiatria e religião disputam porque tratam de um mesmo assunto central: a salvação, e não porque são guiadas pela razão (a psiquiatria) e pela fé (a assistência religiosa), as quais seriam incompatíveis. Tanto não são incompatíveis que se pode passar de uma para outra sem grandes dramas. Talvez fosse mais produtivo e até mais digno os dois domínios admitirem que buscam o mesmo propósito (a salvação) mediante linguagens distintas. A diferença é que, com relação aos saberes secretos e dons, o religioso ao contrário do médico - não tem o respaldo da comunidade científica o que o coloca sempre em desvantagem num espaço que é eminentemente científico. Assim, vê-se a psiquiatria exigir a capacitação dos religiosos para que falem a linguagem médica, científica.

Psiquiatras criticam a homogeneização religiosa hospitalar, defendem a mudança no conceito de capelania (que não deve estar vinculado a nenhuma religiosidade e sim à espiritualidade), mas pretendem uma linguagem homogênea no hospital: a linguagem científica. Tem o sentido do jogo aquele que pertence ao campo: esse argumento serve para desmerecer aquele que se aproxima, entretanto, ele não deixa de ser real. A tentativa de falar uma mesma linguagem (científica) pode ser frustrada por conta disso. Por outro lado, todos falarem a mesma língua é impingir uma harmonia que não combina com a multiplicidade do todo social.

Sob um tipo de relação os psiquiatras são iguais aos especialistas religiosos que detêm um conhecimento secreto. Num outro sentido, estes são leigos/ dominados em relação aos psiquiatras ${ }^{434}$ no que diz respeito a um conhecimento específico. Entretanto, os "ouvidos musicais" dos religiosos para as angústias humanas, os colocam em vantagem frente aos psiquiatras. Mesmo o campo religioso no IPQ-HCFMUSP sendo insignificante frente ao campo médico, fora deste campo (no espaço dos pacientes) a história pode ser diferente. As demandas é que determinam o maior ou menor valor de um campo. Ainda que se admita que a produção científica dirige-se, prioritariamente, aos próprios produtores do campo (ao

\footnotetext{
${ }^{434}$ Porém, são dominantes no campo religioso, onde não ocupam mais a posição de leigos e sim de especialistas.
} 
contrário da produção religiosa), no espaço da clínica, fora do espaço acadêmico, eles deverão de alguma forma alcançar as demandas dos leigos. Essa é a maior das "verdades" - dando continuidade à indagação quanto à possibilidade de se dizer algum tipo de verdade - que, talvez, possa ser aqui emitida. 


\section{REFERÊNCIAS BIBLIOGRÁFICAS ${ }^{435}$}

ALMEIDA, A. M et AL. "Núcleo de problemas espirituais e religiosos" in: Revista de Psiquiatria Clínica. São Paulo: Instituto de Psiquiatria da Faculdade de Medicina da USP, v. 27, n. 2, 2000. Disponível em: <http://www.hcnet.usp.br/ipq/revista/> Acesso em: 10/08/2004.

ALVES, R. "A empresa da cura divina: um fenômeno religioso?" In: EDÊNIO, V. (org.) A cultura do povo. São Paulo: Cortez, 1984. 144 p.

ANTUNES, J. L. F. Hospital: Instituição e história social. São Paulo: Editora Letras e Letras, 1991. $168 \mathrm{p}$.

ASSUNÇÃO, L. M. Religião e migração: revisitando uma velha questão. Dissertação de mestrado, São Paulo: FFLCH/USP, 2004. 165 p.

BASAGLIA, F. A instituição negada: relato de um hospital psiquiátrico. 3. ed. Rio de Janeiro: Edições Graal, 1985. 326 p.

BAZZO, Ézio F. Dymphne: a santa protetora dos loucos. Brasília- DF: Clepto Publicadora, 2000. $141 \mathrm{p}$.

BECKER, H. S. Outsiders: estudos de sociologia do desvio. Rio de janeiro: Jorge Zahar Ed, 2008. 231 p.

BERGER, P. L. O dossel sagrado: elementos para uma teoria sociológica da religião. São Paulo: Ed. Paulinas, 1985. 194 p.

BIRMAN, J. A psiquiatria como discurso da moralidade. Rio de Janeiro: Edições Graal, 1978a. 453 p.

"Demanda psiquiátrica e saber psicanalítico". In: FIGUEIRA, S. A (COORD.) Sociedade e doença mental. Rio de Janeiro: Campus, 1978b. p. 205-225.

BOLTANSKI, L. As classes sociais e o corpo. 4. ed. São Paulo: Paz e Terra, 2004. $179 \mathrm{p}$.

\footnotetext{
${ }^{435}$ De acordo com a Associação Brasileira de Normas Técnicas.
} 
BOURDIEU, P. Esquisse d'une théorie de la pratique. Genève, Lib. Droz, 1972.

"Le champ scientifique". Actes de la Recherche em Sciences Sociales, n. 2/3, jun. 1976, p. 88-104 in Pierre Bourdieu: sociologial Organizador da coletânea Renato Ortiz; tradução de Paula Montero. São Paulo: Ática, 1983a. p. 122-155 Limitada, 1983b. 208 p.

Questões de sociologia. Rio de Janeiro: Editora Marco Zero Homo Academicus. Paris: Les Éditions de Minuit, 1984. 317 p.

As regras da arte: gênese e estrutura do campo literário. São Paulo, Companhia das Letras, 1996a. $431 \mathrm{p}$.

Razões práticas: sobre a teoria da ação. Campinas, SP: Papirus, 1996b. 224 p.

"Gênese e Estrutura do Campo religioso", "Apêndice I: Uma interpretação da teoria da religião de Max Weber" p. 27-98 in: A economia das trocas simbólicas Sérgio Miceli (org). 5. Ed. São Paulo: Ed. Perspectiva, 1999. 361 p.

320 p.

Meditações pascalianas. Rio de Janeiro: Bertrand Brasil, 2001. Béarn. Paris: Seuil, 2002.

Le bal des célibataires: Crise de la société paysanne en Os usos sociais da ciência: por uma sociologia clínica do campo científico. São Paulo: editora UNESP, 2004a. 86 p.

Coisas ditas. São Paulo: Brasiliense, 2004b. 234 p.

2005. 140 p.

Esboço de auto-análise. São Paulo: Companhia das Letras, 
A produção da crença: contribuição para uma economia dos bens simbólicos. Porto Alegre, RS: Zouk, 2006. 219 p.

O poder simbólico. Rio de Janeiro: Bertrand Brasil, 2007. 311 p.

A distinção: crítica social do julgamento. São Paulo: Edusp; Porto Alegre: Zouk, 2008. 560 p.

BRÉCHON, P. "Les attitudes religieuses em France: quelles recompositions en cours?" p. 11-30. In Archives de sciences sociales des religions, 109, Janvier-Mars, CNRS, 2000. 147 p.

CAMPBELL, C. "A orientalização do ocidente: Reflexões sobre uma nova teodicéia para um novo milênio" p. 5-22 in Religião e sociedade Vol. 18 n. 1, Rio de janeiro, 1997. 148 p.

CANGUILHEM, G. O normal e o patológico, 6. ed. ver. Rio de janeiro: Forense Universitária, 2006. 293 p.

CARVALHO , A. M. T. de O sujeito nas encruzilhadas da Saúde: um discurso sobre o processo de construção de sentido e de conhecimento sobre sofrimento difuso e realização do ser no âmbito das religiões afro-brasileiras e sua importância para o campo da Saúde Coletiva. Tese de doutorado, Fundação Oswaldo Cruz, 2004.

CHAUÍ, M. Cultura e democracia: o discurso competente e outras falas. São Paulo: Cortez, 2006. 367 p.

CLAVREUL, J. A ordem Médica: Poder e impotência do discurso médico. São Paulo: Brasiliense, 1983. 274 p.

CONCONE, M. H. V. B. "Cura e visão de mundo" In: Revista Kairós, São Paulo, 6 (2), Dez. 2003, pp. 45-59.

COOPER, D. Psiquiatria e Antipsiquiatria. São Paulo: Editora Perspectiva, 1989. 162 p.

COSTA, Jurandir Freire. A psiquiatria no Brasil: um corte ideológico, 5. ed. rev. Rio de Janeiro: Garamond, 2007.140 p. 
CUNHA, M. C. P. O espelho do mundo - Juquery, a história de um asilo. Rio de Janeiro: Paz e terra, 1986. 217 p.

DALGALARRONDO, P.; GATTAZ, W.F. "A psychiatric unit in a general hospital in Brazil: Predictors of lenght of stay". Soc. Psyquiatry Epidemiol v. 27, p. 147-150, 1992.

DURHAM, E. "Cultura e ideologia". Revista de Ciências Sociais, Rio de Janeiro, Vol. 27, nº 1, 1984, pp. 71 a 89.

DURKHEIM, E. As formas elementares de vida religiosa: o sistema totêmico na Austrália. São Paulo: Ed. Paulinas, 1989. 536 p.

ELIAS, N. Mozart: sociologia de um gênio. Rio de Janeiro: Jorge Zahar Ed., 1995. $150 \mathrm{p}$.

Os estabelecidos e os outsiders. Rio de Janeiro: Jorge zahar Ed., 2000.

224 p.

A sociedade de corte: investigação sobre a sociologia da realeza e da

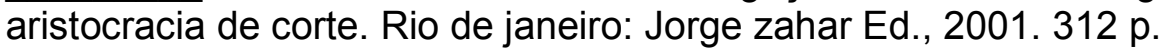

EVANS- PRITCHARD, E. E. Bruxaria, Oráculos e Magia entre os Azande. Rio de Janeiro: Zahar Editores, 1978. 316 p.

EY, H. Naissance de la médecine. Paris, Masson, 1981.

FERNANDES, R. C. (coord.) et al. Novo nascimento: os evangélicos em casa, na igreja, e na política. Rio de janeiro, Mauad, 1998.

FOUCAULT, Michel. Microfísica do poder. 23. ed. Rio de Janeiro: Edições Graal, 1979. $295 \mathrm{p}$.

Brasileiro, 2000. 99 p.

Doença mental e psicologia. 6. ed. Rio de janeiro, Tempo 
História da loucura: Na idade clássica, 8. ed. São Paulo: perspectiva, 2005. (Estudos; 61/ dirigida por J. Guinsburg). 551 p.

Universitária, 2006. $231 \mathrm{p}$.

O nascimento da clínica. 6. ed. Rio de Janeiro: Forense

GOFFMAN, E. A representação do eu na vida cotidiana. 10. ed. Petrópolis, Vozes, 2002. 233 p.

2005. 312 p.

. Manicômios, prisões e conventos. 7. ed. São Paulo: Perspectiva,

GOOD, B. J. Medicina, racionalidad y experiência: una perpectiva antropológica. Barcelona, Edicions Bellaterra, 2003. 375 p.

GUIMARÃES, H. P.; AVEZUM, A. "O impacto da espiritualidade na saúde física". Revista de Psiquiatria Clínica. São Paulo: Instituto de Psiquiatria da Faculdade de Medicina da USP, v. 34, Suplemento 1, p. 88-94, 2007. Disponível em: <http://www.hcnet.usp.br/ipq/revista/> Acesso em: 20/10/2008.

KOENIG, H. G. Espiritualidade no cuidado com o paciente: Porquê, como quando e o quê. São Paulo:FE Editora Jornalística, 2005, 140p.

"Religião, espiritualidade e transtornos psicóticos". Revista de Psiquiatria Clínica. São Paulo: Instituto de Psiquiatria da Faculdade de Medicina da USP, v. 34, n. 3, p. 95-104, 2007. <http://www.hcnet.usp.br/ipq/revista/> Acesso em: 20/10/2008.

LAPLANTINE, F Antropologia da doença, $3^{a}$ Ed. São Paulo: Martins Fontes, 2004. $274 p$.

LARSON, D.B; PATTISON, E.M; BLAZER, D.G; OMRAN, A.R; KAPLAN, B.H "Systematic analysis of research on religious variables in four major psychiatric journals, 1978-1982”. American Journal of Psychiatry v. 143: p. 329-334, 1986.

. "The measurement of religion in psychiatric research". In: Robinson LH (ed) Psychiatry and Religion: overlapping concerns. Washington DC, American Psychiatric Press, 1986. 
LOTUFO-NETO, F. Psiquiatria e religião: a prevalência de transtornos mentais entre ministros religiosos. Tese de livre-docência. São Paulo: Departamento de Psiquiatria/USP, 1997. 376 p.

LOTUFO-NETO et al. "Núcleo de problemas espirituais e religiosos" in: Revista de Psiquiatria Clínica. São Paulo: Instituto de Psiquiatria da Faculdade de Medicina da USP, v. 27, n. 2, 2000. Disponível em: <http://www.hcnet.usp.br/ipq/revista/> Acesso em: 10/08/2004.

LUZ, Madel T. "Medicina e racionalidades médicas: estudo comparativo da medicina ocidental contemporânea, homeopática, tradicional chinesa e ayurvédica" in: CANESQUI, Ana Maria (org.). Ciências sociais e saúde para o ensino médico. São Paulo: Editora Hucitec/FAPESP, 2000. 283 p.

MACHADO, A. L. Espaços de representação da loucura: Religião e psiquiatria. Campinas: Papirus, 2001. 128 p.

MERLEAU-PONTY, M. (1942). La structure du comportement. Paris, PUF, 1990, (Coll. Quadrige).

MERTON, R. K "Anomie, Anomia e interacción social: contextos de conducta desviada". In: CLINARD, M. B, comp. Anomia y conduta desviada. Buenos Aires, Paidós, 1967.

Sociologia, Teoria e Estrutura. São Paulo: Mestre Jou, 1970.

MICELI, S. "Introdução: A força do sentido"; in: A economia das trocas simbólicas Sérgio Miceli (org). São Paulo: Ed. Perspectiva, 1999, 5ª Ed, p. VII-LXI.

MINAYO, M. C. de Souza. O desafio do conhecimento: pesquisa qualitativa em saúde. 10. ed. São Paulo: Hucitec, 2007. 406 p.

MONTERO, Paula. Da doença à desordem: a magia na Umbanda. Rio de Janeiro: Edições Graal, 1985. 274p.

NEGRÃO, Lísias N. "Trajetórias do sagrado". In: Tempo Social. Revista de Sociologia da USP. Departamento de sociologia, FFLCH, USP. - V. 20, n. 2 (novembro 2008). São Paulo: USP, FFLCH, 1989. 306 p. 
Nem "jardim encantado", nem "clube dos intelectuais desencantados" In Revista brasileira de Ciências Sociais, vol.20, n. 59, São Paulo, Oct. 2005.

Relatório científico anual do projeto temático Urdindo novas tramas: trajetórias do sagrado, 2001.

OLIVEIRA, Elda Rizzo de. O que é benzeção. São Paulo: Brasiliense, 1985. 110 p.

ORTIZ, Renato. "A procura de uma sociologia da prática" In: Pierre Bourdieu: sociologia. ORTIZ, Renato (org.). São Paulo: Ática, 1983 (Col. Grandes Cientistas Sociais, vol. 39). p. 7-36. 191 p.

OURY, J. Itinerários de formação. Traduzido de Revue Pratique. n.2 p. 42-50, 1991, por Jairo Goldberg/mimeografado.

PANZINI, R. G. et al. "Qualidade de vida e espiritualidade". Revista de Psiquiatria Clínica. São Paulo: Instituto de Psiquiatria da Faculdade de Medicina da USP, v. 34, Suplemento 1, p. 105-115, 2007. <http://www.hcnet.usp.br/ipq/revista/> Acesso em: 20/10/2008.

PEREIRA NETO, A F. Ser médico no Brasil: o presente no passado. Rio de Janeiro: Editora Fiocruz, 2001. 232 p.

PERES et al. "Espiritualidade, religiosidade e psicoterapia". Revista de Psiquiatria Clínica. São Paulo: Instituto de Psiquiatria da Faculdade de Medicina da USP, v. 34, n. 3, p. 136-145, 2007. <http://www.hcnet.usp.br/ipq/revista/> Acesso em: 20/10/2008.

POPPER, K. La logique de la découverte scientifique. Paris: Payot, 1973.

PIERUCCI, A. \& PRANDI, R. A realidade social das religiões no Brasil. São Paulo, Hucitec, 1996. 293 p.

PIERUCCI, A. F. O desencantamento do mundo: todos os passos do conceito em Max Weber. São Paulo: USP, Curso de Pós- Graduação em Sociologia: Ed. 34, 2003. $236 \mathrm{p}$. 
PRANDI, R. Os candomblés de São Paulo: a velha magia na metrópole nova. São Paulo: Hucitec, 1991. 261 p.

PINTO, L. Pierre Bourdieu e a teoria do mundo social. Rio de Janeiro: Editora FGV, 200. 192 p.

PUTTINI, Rodolfo Franco. Medicina e religião no espaço hospitalar. Tese de Doutorado, Campinas: Faculdade de Ciências Médicas/UNICAMP, 2004. 290 p.

QUINTANA, A. M A ciência da benzedura: mau olhado, simpatias e uma pitada de psicanálise. Bauru: EDUSC, 1999. 226p.

REGO, S. A. "A medicalização do hospital no Brasil: notas de estudo". Revista Médica de Minas Gerais 3(1): 54-57, 1993.

REVISTA DE PSIQUIATRIA CLÍNICA. São Paulo: Instituto de Psiquiatria da Faculdade de Medicina da USP, v. 34, Suplemento 1, 2007. 155 p. <http://www.hcnet.usp.br/ipq/revista/> Acesso em: 20/10/2008. 155 p.

SANCHEZ, Z V M; NAPPO, S A. "A religiosidade, a espiritualidade e o consumo de drogas". Revista de Psiquiatria Clínica. São Paulo: Instituto de Psiquiatria da Faculdade de Medicina da USP, v. 34, Suplento 1, p. 73-81, 2007. <http://www.hcnet.usp.br/ipq/revista/> Acesso em: 20/10/2008.

SCHWEICKARDT, J. C. Magia e religião na modernidade: Os rezadores em Manaus. Manaus: Editora da Universidade do Amazonas, 2002. 269 p.

SILVA, L. B. C. Doença mental, psicose, loucura: representações e práticas da equipe multiprofissional de um hospital-dia. São Paulo: Casa do psicólogo, 2001. $466 \mathrm{p}$.

SILVA, Vagner Gonçalves da. Orixás da metrópole. Petrópolis: Vozes, 1995. 325 p.

SOUZA, Beatriz M. A experiência da salvação: pentecostais em São Paulo. São Paulo: Duas Cidades, 1969. 181 p.

SZASZ, Thomas S. A fabricação da loucura: um estudo comparativo entre a inquisição e o movimento de saúde mental. 3. ed. Rio de Janeiro: Zahar editores, 1978. $408 \mathrm{p}$. 
$258 \mathrm{p}$.

. O mito da doença mental. Rio de janeiro: Zahar editors, 1979.

TROELTSCH, E. (1958) Protestantism and progress: a historical study of the relation of Protestantism to the modern world. 1. ed. 1907. Londres, Beacon Press.

. “Igreja e seitas”. Religião e sociedade, 14 (3), 1987.

VELHO, G. "O estudo do comportamento desviante: a contribuição da antropologia social”. In: VELHO, G. (org.) Desvio e divergência: uma crítica da patologia social. 8. ed. Rio de Janeiro: Jorge Zahar Ed., 2003. 144 p.

WEAVER, A.J.; Samford, J.A.; Larson, D.B. et al. "A systematic review of research on religion in four major psychiatric journals: 1991-1995" In: Journal of nervous and mental disease, 1998.

WEBER, Max. "Rejeições religiosas do mundo e suas direções", "Psicologia social das religiões mundiais". In: Gerth, H e Mills, C.W.( orgs) Ensaios de Sociologia. Rio de Janeiro: Zahar, 1963. p. 309-346 e p. 371-410.

$124 \mathrm{p}$.

Ciência e política: duas vocações. 9. ed. São Paulo: Cultrix, 1993.

"Sociologia da religião (tipos de relações comunitárias religiosas)" p. 279-418 In: (Org) Johannes Winckelmann Economia e sociedade - Fundamentos da sociologia compreensiva, vol.1, Brasília: UNB, 1994. 422 p.

A ética protestante e o "espírito" do capitalismo. São Paulo:

Companhia das Letras, 2004. 335 p. 
APÊNDICE - Roteiros de entrevistas 


\section{ROTEIRO DE ENTREVISTA COM MÉDICOS-PSIQUIATRAS (RELIGIOSOS E NÃO RELIGIOSOS)}

1) Você tem conhecimento do serviço religioso que existe no HCUSP? (se necessário explicar do que se trata o serviço religioso)

- Você sabe como funciona a entrada de religiões no Instituto de psiquiatria? Qualquer religião pode entrar aqui?

2) Você já teve contato com algum dos religiosos que trabalham no hospital?

3) O que acha da presença religiosa nos hospitais? (A favor ou contra o serviço religioso no HC?)

4) De um modo geral, como os médicos-psiquiatras encaram o serviço religioso no IPQ-HC?

5) Você acha importante o atendimento religioso aos pacientes psiquiátricos (Se $\operatorname{sim} \rightarrow$ Qual a importância do atendimento religioso aos pacientes psiquiátricos?)

6) Em relação aos pacientes, quando assuntos espirituais complexos se fazem presentes qual a postura você acha que deve ser tomada? (considera importante encaminhar o paciente a uma pessoa com mais conhecimento na área ou o assunto pode ser resolvido pelo profissional de saúde mesmo?)

7) Como é a relação dos médicos-psiquiatras com os ministros religiosos no IPQ-HC? Existe uma convivência constante ou não?

8) Um diálogo entre médicos e religiosos no interior dos hospitais pode ser útil no tratamento das doenças?

E no caso do IPQ, pode ser útil no tratamento das doenças?

9) No seu ponto de vista, você consegue perceber alguma relação entre medicina e religião? De que forma? Você acha que existe algo em comum entre esses dois setores?

10) Os assuntos vinculados à fé, à religião são compatíveis ou não com os objetivos da ciência? Em que medida?

11) Em função de pontos de vista e de formas de atuação distintas, você acha possível haver um trabalho conjunto entre religião e psiquiatria? (Se sim $\rightarrow$ Como é possível fazer um trabalho conjunto? Qual o envolvimento pode haver entre essas áreas?)

12) Considera que as crenças espirituais/religiosas podem interferir no tratamento médico? Em que sentido?

13) Considera a religião, a fé importante ou não para o paciente lidar com a doença?

14) Você tem conhecimento de algum caso de paciente que se beneficiou do atendimento religioso aqui no hospital?

15) O que você acha da afirmação - que se baseia em pesquisas - segundo a qual, na maioria dos casos, "as pessoas que têm crenças religiosas, que são religiosos praticantes, tendem a ter melhor qualidade de vida e saúde que as que não as têm?"

16) O que você acha da afirmação de que pacientes que possuem alguma religião melhoram mais rapidamente do que aqueles que não possuem?

17) Como você acha que os ministros religiosos se posicionam em relação aos diagnósticos e tratamentos dados pelos médicos - psiquiatras? Eles opinam sobre isso de alguma forma?

18) Você acha que o serviço religioso do HC exerce algum tipo de influência sobre a psiquiatria? De que forma? 


\section{ROTEIRO DE ENTREVISTA COM MÉDICOS-PSIQUIATRAS (RELIGIOSOS E NÃO RELIGIOSOS)-cont.}

19) Você saberia dizer de que forma os médicos se posicionam em relação à religiosidade dos pacientes? $\mathrm{E}$ em relação ao trabalho religioso no hospital?

20) Você acha que a psiquiatria do HC exerce algum tipo de influência sobre o serviço religioso? De que forma?

21) Nas últimas décadas, tem ocorrido a introdução do fator espiritualidade nos estudos, pesquisas e na própria práxis médica. Por ex., nos EUA, há cursos obrigatórios ou eletivos sobre religião, espiritualidade e medicina, em cerca de dois terços das escolas médicas. O que você pensa disso? Considera importante a inclusão da espiritualidade no contexto médico? De que forma você considera que essa inclusão pode ser feita?

22) Existe um curso de formação em aconselhamento pastoral que prepara os religiosos para tratarem de questões psicológicas com os fiéis. Saberia dizer qual é a idéia principal desse curso? Quando e por que surgiu essa idéia?

Você tem alguma informação sobre isso ou sobre algum outro tipo de curso?

23) Já em relação aos médicos, apesar de existirem disciplinas nas áreas de religião/espiritualidade e medicina, os já formados normalmente não têm treinamento nessa área. O que você acha dos médicos terem treinamento para lidar com questões espirituais?

24) De um modo geral, o que você pensa de um médico falar com seu paciente sobre assuntos relacionados à fé, religião?

- O Médico deve considerar, estar atento à crença religiosa do paciente?

- O médico deve fazer o levantamento da história espiritual do paciente? Com relação à crença do paciente ele deve tomar alguma atitude? (Se sim, qual? Se não, por quê?)

- É importante que o médico entenda o papel das crenças do paciente para a saúde e a doença?

- Acha necessário que o médico identifique e leve em consideração as necessidades espirituais dos pacientes?

- No Instituto de Psiquiatria, os médicos costumam entrar em questões espirituais com seus pacientes?

- Você já conversou com algum paciente sobre religião?

25) Você acha necessário um maior engajamento dos médicos na questão dos efeitos da religião na saúde e uma maior atenção em relação a quando abordar assuntos religiosos. (Se sim $\rightarrow$ O que você acha necessário para que os médicos estejam mais engajados e mais atentos? O treinamento e a exposição dos médicos às pesquisas em religião e saúde podem ser úteis nesse sentido?)

26) Você segue alguma religião? Você tem conhecimento das crenças dos outros funcionários, dos médicos?

27) Qual a importância da religião na sua vida?

28) Participa de alguma atividade religiosa no hospital? Do que se trata? 


\section{ROTEIRO DE ENTREVISTA COM ENFERMEIROS (RELIGIOSOS E NÃO RELIGIOSOS)}

1) Você tem conhecimento do serviço religioso que existe no HCUSP? (se necessário explicar do que se trata o serviço religioso)

- Você sabe como funciona a entrada de religiões no Instituto de psiquiatria? Qualquer religião pode entrar aqui?

2) Você já teve contato com algum dos religiosos que trabalham no hospital?

3) O que acha da presença religiosa nos hospitais? (A favor ou contra o serviço religioso no HC?)

4) De um modo geral, como os enfermeiros encaram o serviço religioso no IPQ-HC?

5) Você acha importante o atendimento religioso aos pacientes psiquiátricos (Se $\operatorname{sim} \rightarrow$ Qual a importância do atendimento religioso aos pacientes psiquiátricos?)

6) Em relação aos pacientes, quando assuntos espirituais complexos se fazem presentes qual a postura você acha que deve ser tomada? (considera importante encaminhar o paciente a uma pessoa com mais conhecimento na área ou o assunto pode ser resolvido pelo profissional de saúde mesmo?)

7) Como é a relação dos enfermeiros com os ministros religiosos no IPQ-HC? Existe uma convivência constante ou não?

8) Um diálogo entre enfermeiros e religiosos no interior dos hospitais pode ser útil no tratamento das doenças?

E no caso do IPQ, pode ser útil no tratamento das doenças?

9) No seu ponto de vista, você consegue perceber alguma relação entre medicina e religião? De que forma? Você acha que existe algo em comum entre essas dois setores?

10) Os assuntos vinculados à fé, à religião são compatíveis com os objetivos da ciência? Em que medida?

11) Em função de pontos de vista e de formas de atuação distintas, você acha possível haver um trabalho conjunto entre religião e psiquiatria? (Se sim $\rightarrow$ Como é possível fazer um trabalho conjunto? Qual o envolvimento pode haver entre essas áreas?)

12) Considera que as crenças espirituais/religiosas podem interferir no tratamento médico? Em que sentido?

13) Considera a religião, a fé importante ou não para o paciente lidar com a doença?

14) Você tem conhecimento de algum caso de paciente que se beneficiou do atendimento religioso aqui no hospital?

15) O que você acha da afirmação - que se baseia em pesquisas - segundo a qual, na maioria dos casos, "as pessoas que têm crenças religiosas, que são religiosos praticantes, tendem a ter melhor qualidade de vida e saúde que as que não as têm?"

16) O que você acha da afirmação: "pacientes que possuem alguma religião melhoram mais rapidamente do que aqueles que não possuem"?

17) Você saberia dizer se os ministros religiosos se posicionam em relação aos diagnósticos e tratamentos dados pelos médicos - psiquiatras aos pacientes? Eles opinam sobre isso?

18) Você acha que o serviço religioso do HC exerce algum tipo de influência sobre a psiquiatria? De que forma? 


\section{ROTEIRO DE ENTREVISTA COM ENFERMEIROS (RELIGIOSOS E NÃO RELIGIOSOS)-cont.}

19) Você saberia dizer de que forma os médicos se posicionam em relação à religiosidade dos pacientes? $\mathrm{E}$ em relação ao trabalho religioso no hospital?

20) Você acha que a psiquiatria do HC exerce algum tipo de influência sobre o serviço religioso? De que forma?

21) Nas últimas décadas, tem ocorrido a introdução do fator espiritualidade nos estudos, pesquisas e na própria práxis médica. O que você pensa disso? Considera importante a inclusão da espiritualidade no contexto médico? Considera importante a inclusão da espiritualidade no contexto do trabalho de enfermagem? De que forma você considera que essa inclusão pode ser feita?

22) Existe um curso de formação em aconselhamento pastoral que prepara os religiosos para tratarem de questões psicológicas com os fiéis. Saberia dizer qual é a idéia principal desse curso? Quando e por que surgiu essa idéia? Você tem alguma informação sobre isso ou sobre algum outro tipo de curso?

23) $\mathrm{E}$ os enfermeiros, o que você acha dos enfermeiros terem cursos e treinamento para lidar com questões espirituais?

24) De um modo geral, o que você pensa de um enfermeiro falar com seu paciente sobre assuntos relacionados à fé, religião?

- O enfermeiro deve considerar, estar atento à crença religiosa do paciente?

- O enfermeiro deve fazer o levantamento da história espiritual do paciente? Com relação à crença do paciente ele deve tomar alguma atitude? (Se sim, qual? Se não, por quê?)

- É importante que o enfermeiro entenda o papel das crenças do paciente para a saúde e a doença?

- Acha necessário que o enfermeiro identifique e leve em consideração as necessidades espirituais dos pacientes?

- No Instituto de Psiquiatria, os enfermeiros costumam entrar em questões espirituais com seus pacientes?

- Você já conversou com algum paciente sobre religião?

25) Você acha necessário um maior engajamento dos enfermeiros na questão dos efeitos da religião na saúde e uma maior atenção em relação a quando abordar assuntos religiosos. (Se sim $\rightarrow$ O que você acha necessário para que os enfermeiros estejam mais engajados e mais atentos? $O$ treinamento e a exposição dos enfermeiros às pesquisas em religião e saúde podem ser úteis nesse sentido?)

26) Você segue alguma religião? Você tem conhecimento das crenças dos outros funcionários, dos médicos?

27) Qual a importância da religião na sua vida?

28) Participa de alguma atividade religiosa no hospital? Do que se trata? 


\section{ROTEIRO DE ENTREVISTA COM MINISTROS RELIGIOSOS}

1) Como se deu a entrada do serviço religioso católico e evangélico dentro do HCUSP? (De que forma essas capelanias atuam no HCUSP? De que forma essas capelanias atuam no IPQ?)

2) Como é a relação entre as capelanias que atuam no interior do HC?

- Qualquer grupo religioso tem permissão para realizar seu trabalho no HCUSP?

3) A nova ordem de serviço $n^{\circ}$ 25/2004 criou o CARE (Comitê de Assistência Religiosa). Neste último, que é composto por serviço religioso católico e protestante, existe a previsão de criação de um outro serviço religioso. Que serviço seria esse? O que acha da participação de outras religiões no hospital?

4) Como é a relação dos ministros religiosos com os médicos no HCUSP? (Como é a relação dos ministros religiosos com os médicos-psiquiatras no IPQ?) Existe uma convivência constante ou não?

5) Um diálogo entre médicos e religiosos no interior dos hospitais pode ser útil no tratamento das doenças?

6) Em função de pontos de vista e de formas de atuação distintas é possível haver um trabalho conjunto entre religião e psiquiatria? (Se sim $\rightarrow$ Como é possível fazer um trabalho conjunto? Qual o envolvimento pode haver entre essas áreas?)

7) No seu ponto de vista, você consegue perceber alguma relação entre medicina e religião? De que forma? Você acha que existe algo em comum entre esses dois setores? (E entre a psiquiatria e a religião? De que forma?)

8) Os assuntos vinculados à fé, à religião são compatíveis ou não com os objetivos da ciência? Em que medida?

9) De um modo geral, como os médicos encaram o serviço religioso dentro do HCUSP?

- De que forma os médicos-psiquiatras encaram o serviço religioso no IPQ?

10) Você saberia dizer de que forma os médicos-psiquiatras se posicionam em relação à religiosidade dos pacientes?

11) De um modo geral, o serviço religioso exerce algum tipo de influência sobre a medicina? De que forma?

No caso específico do HCUSP, o serviço religioso exerce algum tipo de influência sobre a psiquiatria? De que forma?

12) $O$ que você acha de o ministro religioso conversar com o paciente sobre o tratamento indicado pelo médico? É possível que isso aconteça?

13) De que modo os ministros religiosos se posicionam em relação aos diagnósticos e tratamentos dados pelos médicos - psiquiatras? Eles opinam sobre isso de alguma forma?

14) A medicina, de um modo geral, exerce algum tipo de influência sobre o serviço religioso?De que forma?

- No caso específico do HCUSP, a Psiquiatria exerce algum tipo de influência sobre o serviço religioso? De que forma?

15) $O$ ministro religioso deve receber treinamento para saber mais sobre as necessidades espirituais dos pacientes no âmbito médico? Como você acha que deve ser feito isso?

15.1) $O$ voluntário religioso recebe algum tipo de treinamento para realizar trabalho aqui dentro? Como seria esse treinamento? 


\section{ROTEIRO DE ENTREVISTA COM MINISTROS RELIGIOSOS (cont.)}

16) Existe o curso de aconselhamento pastoral que os prepara para tratarem de questões psicológicas com os fiéis. Saberia dizer qual é a idéia principal desse curso? Quando e por que surgiu essa idéia? Você tem alguma informação sobre isso ou sobre algum outro tipo de curso? (Como o curso de formação em aconselhamento pastoral oferecido pelos médicos-psiquiatras aos ministros religiosos é encarado? O que você tem a dizer sobre a proposta e sobre o conteúdo do curso?)

17) Em relação aos médicos, apesar de existirem disciplinas nas áreas de religião/espiritualidade e medicina, os já formados normalmente não têm treinamento nessa área. O que você acha dos médicos terem treinamento para lidar com questões espirituais?

18) Nas últimas décadas, tem ocorrido a introdução do fator espiritualidade nos estudos, pesquisas e na própria práxis médica. Por exemplo, nos EUA, há cursos obrigatórios ou eletivos sobre religião, espiritualidade e medicina, em cerca de dois terços das escolas médicas. O que você pensa disso? Considera importante a inclusão da espiritualidade no contexto médico? De que forma você considera que essa inclusão pode ser feita?

19) Considera a religião, a fé importante ou não para o paciente lidar com a doença? Considera que as crenças espirituais/religiosas podem influenciar no curso da doença? Em que sentido?

20) De um modo geral, o que você pensa de um médico falar com seu paciente sobre assuntos relacionados à fé, religião?

- O Médico deve considerar, estar atento à crença religiosa do paciente?

- O médico deve fazer o levantamento da história espiritual do paciente? Com relação à crença do paciente ele deve tomar alguma atitude? (Se sim, qual? Se não, por quê?)

21) O que você acha da afirmação - que se baseia em pesquisas - segundo a qual, na maioria dos casos, "as pessoas que têm crenças religiosas, que são religiosos praticantes, tendem a ter melhor qualidade de vida e saúde que as que não as têm?"

22) O que você acha da afirmação de que pacientes que possuem alguma religião melhoram mais rapidamente do que aqueles que não possuem?

23) Você acha importante o atendimento religioso aos pacientes psiquiátricos (Se $\operatorname{sim} \rightarrow$ Qual a importância do atendimento religioso aos pacientes psiquiátricos?)

24) Considera que as crenças espirituais/religiosas podem interferir no tratamento médico? Em que sentido?

25) Em relação aos pacientes, quando assuntos espirituais complexos se fazem presentes qual a postura você acha que deve ser tomada? (considera importante encaminhar o paciente a uma pessoa com mais conhecimento na área ou o assunto pode ser resolvido pelo profissional de saúde mesmo?) 


\section{ROTEIRO DE ENTREVISTA COM PACIENTES}

1) Quanto tempo está internado (a)?

2) Do que está se tratando? Fale sobre o seu adoecimento

3) Você possui alguma religião? Qual? Fale sobre a sua religião

4) Qual a importância da religião na sua vida? Em que medida ela é importante para você?

5) O que você acha de haver serviço religioso no HCUSP?

6) Você conhece ou já ouviu falar do serviço religioso que existe no HCUSP? (se necessário explicar do que se trata o serviço religioso)

7) Você já teve contato com algum dos religiosos que trabalham no hospital? Recebeu alguma visita de religiosos? O que achou? (se não, pular para questão 13)

8) Como é a relação dos religiosos (padres e pastores) com os pacientes no hospital? Como você se sente em relação ao trabalho que eles realizam junto aos pacientes?

9) Você acha que deveria haver outros serviços religiosos aqui dentro?

10) Você se sente à vontade para falar de suas crenças com os religiosos?

11) O que os religiosos acham do tratamento médico que você faz?

12) O que você acha do paciente conversar sobre questões do tratamento médico com os religiosos?

13) No tempo em que você está internado aqui, o que você achou do relacionamento dos médicos com os pacientes no hospital?

14) No tempo em que você está internado aqui, o que você achou do relacionamento dos enfermeiros com os pacientes no hospital?

15) Você teria algo a sugerir a esses profissionais para melhorar ainda mais a relação com os pacientes no dia-adia?

16) O que você acha do paciente conversar sobre suas necessidades religiosas/espirituais com seu médico ou com o enfermeiro?

17) Você se sentiria à vontade para falar de questões religiosas/espirituais suas com os médicos ou com os enfermeiros?

18) Você já tentou falar de questões religiosas/espirituais com seu médico ou com o enfermeiro? Qual foi a reação dele? O que ele disse?

19) Você acha que o médico deve perguntar ao paciente sobre suas crenças religiosas? Você acha que o enfermeiro deve perguntar ao paciente sobre suas crenças religiosas?

20) Como você se sentiria se um médico ou um enfermeiro falasse de questões religiosas/espirituais com você? 


\section{ROTEIRO DE ENTREVISTA COM VOLUNTÁRIOS RELIGIOSOS}

1) Como se deu a entrada do serviço religioso católico e evangélico dentro do HCUSP?

- De que forma essas capelanias atuam no HCUSP?

2) Como é a relação entre as capelanias que atuam no interior do HC?

- Qualquer grupo religioso tem permissão para realizar seu trabalho no HCUSP?

3) A qual serviço religioso você está ligado (a)? A quanto tempo atua como voluntário nesse serviço religioso?

4) Como aconteceu a sua entrada no serviço religioso?

5) Como é a relação dos voluntários do serviço religioso com os médicos no HCUSP? Existe uma convivência constante ou não? (Como é a relação dos voluntários religiosos com os médicos-psiquiatras no IPQ?)

6) Como é a relação entre os voluntários das duas capelanias? E a relação dos voluntários com os ministros religiosos (padres, pastores)?

7) Em função de pontos de vista e de formas de atuação distintas é possível haver um trabalho conjunto entre religião e medicina (psiquiatria)? (Se sim $\rightarrow$ Como é possível fazer um trabalho conjunto? Qual o envolvimento pode haver entre essas áreas?)

8) No seu ponto de vista, você consegue perceber alguma relação entre medicina e religião? De que forma? Você acha que existe algo em comum entre esses dois setores? (E entre a psiquiatria e a religião? De que forma?)

9) Os assuntos vinculados à fé, à religião são compatíveis ou não com os objetivos da ciência? Em que medida?

10) De um modo geral, como os médicos, os enfermeiros encaram o serviço religioso dentro do HCUSP? (De que forma os médicos-psiquiatras encaram o serviço religioso no IPQ?)

11) Você saberia dizer de que forma os médicos (psiquiatras) se posicionam em relação à religiosidade dos pacientes? E em relação ao trabalho religioso no hospital?

12) De um modo geral, o serviço religioso exerce algum tipo de influência sobre a medicina? De que forma?

(No caso específico do HCUSP, o serviço religioso exerce algum tipo de influência sobre a psiquiatria? De que forma?)

13) Os voluntários se posicionam em relação aos diagnósticos e tratamentos dados pelos médicos (psiquiatras)? De que modo os voluntários religiosos se posicionam? Os voluntários opinam sobre isso de alguma forma?

14) A medicina, de um modo geral, exerce algum tipo de influência sobre o serviço religioso?De que forma?

(No caso específico do HCUSP, a Psiquiatria exerce algum tipo de influência sobre o serviço religioso? De que forma?)

15) O voluntário religioso deve receber treinamento para saber mais sobre as necessidades espirituais dos pacientes no âmbito médico? Como você acha que deve ser feito isso?

16) Existe um curso de formação em aconselhamento pastoral que prepara os religiosos para tratarem de questões psicológicas com os fiéis. Saberia dizer qual é a idéia principal desse curso? Quando e por que surgiu essa idéia? Você tem alguma informação sobre isso ou sobre algum outro tipo de curso? 


\section{ROTEIRO DE ENTREVISTA COM VOLUNTÁRIOS RELIGIOSOS-cont.}

17) Em relação aos médicos, apesar de existirem disciplinas nas áreas de religião/espiritualidade e medicina, os já formados normalmente não têm treinamento nessa área. O que você acha dos médicos terem treinamento para lidar com questões espirituais?

18) Nas últimas décadas, tem ocorrido a introdução do fator espiritualidade nos estudos, pesquisas e na própria práxis médica. Por exemplo, nos EUA, há cursos obrigatórios ou eletivos sobre religião, espiritualidade e medicina, em cerca de dois terços das escolas médicas. O que você pensa disso? Considera importante a inclusão da espiritualidade no contexto médico? De que forma você considera que essa inclusão pode ser feita?

19) Considera a religião, a fé importante ou não para o paciente lidar com a doença? Considera que as crenças espirituais/religiosas podem influenciar no curso da doença? Em que sentido?

20) De um modo geral, o que você pensa de um médico falar com seu paciente sobre assuntos relacionados à fé, religião?

- O Médico deve considerar, estar atento à crença religiosa do paciente?

- O médico deve fazer o levantamento da história espiritual do paciente? Com relação à crença do paciente ele deve tomar alguma atitude? (Se sim, qual? Se não, por quê?)

21) O que você acha da afirmação - que se baseia em pesquisas - segundo a qual, na maioria dos casos, "as pessoas que têm crenças religiosas, que são religiosos praticantes, tendem a ter melhor qualidade de vida e saúde que as que não as têm?"

22) O que você acha da afirmação de que pacientes que possuem alguma religião melhoram mais rapidamente do que aqueles que não possuem?

23) Você acha importante o atendimento religioso aos pacientes psiquiátricos (Se sim $\rightarrow$ Qual a importância do atendimento religioso aos pacientes psiquiátricos?)

24) Considera que as crenças espirituais/religiosas podem interferir no tratamento médico? Em que sentido?

25) Em relação aos pacientes, quando assuntos espirituais complexos se fazem presentes qual a postura você acha que deve ser tomada? (considera importante encaminhar o paciente a uma pessoa com mais conhecimento na área ou o assunto pode ser resolvido pelo profissional de saúde mesmo?) 


\section{ROTEIRO DE ENTREVISTA COM FUNDADORES NEPER}

1) Quando o NEPER foi fundado?

2) Como se deu a sua formação?

3) Como se deu início à idéia?

4) Quais eram os objetivos do NEPER à época de sua formação?

5) Os objetivos continuam os mesmos ou houve alguma mudança?

6) Qual é o público alvo do NEPER?

7) Porque o termo "problemas" espirituais e religiosos? Qual é o sentido?

\section{ROTEIRO DE ENTREVISTA- ProSER}

1) Qual a data de retomada/oficialização do ProSER? Este poderia ser considerado uma retomada do NEPER? Estão envolvidas as mesmas pessoas nessa retomada? Qual a motivação para a mudança do nome NEPER para ProSER?

2) Como se deu essa nova constituição (quem idealizou, quem apoiou, as questões burocráticas /institucionais por trás, o espaço cedido, a oficialização passou por quais instâncias), como se deu início à idéia?

3) O ProSER dá prosseguimento aos objetivos do NEPER ou toma caminho diferenciado? Existem outros objetivos para além do desenvolvimento de pesquisas como era objetivo do NEPER anteriormente?

4) Atualmente, qual é o público alvo do ProSER? Como está acontecendo a participação dos profissionais de saúde no ProSER (o nível de adesão)? Quantos médicos são participantes? Considera haver relação de participação no ProSER com a religiosidade dos médicos (mais ou menos religiosos, o tipo de religião (espírita, católico, protestante)?

5) Qual o posicionamento do ProSER em relação ao atendimento religioso a paciente psiquiátrico no IPQ? Considera que os religiosos estão preparados para realizar atendimento religioso a paciente psiquiátrico no IPQ? Que tipo de atendimento religioso o ProSER vislumbra?

6) O ProSER tem participação em atendimento religioso? (Existe projeto em relação a isso? Como funciona? Houve uma reunião com a diretoria do IPQ para tratar disso?)

7) Qual a relação do ProSER com o CARE? A relação com os representantes dos serviços religiosos da capelania hospitalar?

8) O que pensa do espaço dado às religiões junto ao CARE? (A participação dos espíritas é cogitada?) 


\section{ANEXO - Parecer da CAPPesq (Comissão de Ética para Análise de projetos de pesquisa)}


Recebido: 0 / 107 , as $9 \mathrm{~h} \Omega$

Departamento de Psiquatartia da FMUSP

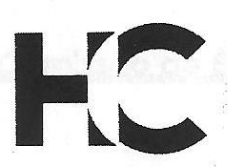

\section{APROVAÇĀO}

A Comissão de Ética para Análise de Projetos de Pesquisa - CAPpesq da Diretoria Clínica do Hospital das Clínicas e da Faculdade de Medicina da Universidade de São Paulo, em sessão de 03/10/2007, APROVOU o Protocolo de Pesquisa $n^{\circ}$ 0475/07, intitulado: "A RELAÇĀo ENTRE MINISTROS RELIGIOSOS, MÉdICOS E PACIENTES NO INSTITUTO DE PSIQUIATRIA DO HOSPITAL DAS CLÍNICAS DE SÃO PAULO " apresentado pelo Departamento de PSIQUIATRIA, inclusive o Termo de Consentimento Livre e Esclarecido.

$$
\text { Cabe ao pesquisador elaborar e apresentar à }
$$

CAPPesq, os relatórios parciais e final sobre a pesquisa (Resolução do Conselho Nacional de Saúde $n^{0} 196$, de 10/10/1996, inciso IX.2, letra "C").

Pesquisador (a) Responsável: FRANCISCO LOTUFO NETO

Pesquisador (a) Executante: LUIZA MARIA DE ASSUNÇĀO

CAPPesq, 08 de Outubro de 2007

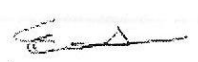

Prof. Dr. Eduardo Massad Presidente da Comissão de Ética para Análise de Projetos de Pesquisa

Comissão de Ética para Análise de Projetos de Pesquisa do HCFMUSP e da FMUSP Diretoria Clinica do Hospital das Clinicas da Faculdade de Medicina da Universidade de São Paulo Rua Ovidio Pires de Campos. 255. $5^{\circ}$ andar - CEP 05403 010 - São Paulo - SP Fone: 01130696442 Fax: 01130696492 e-mail: cappesq@ncnet.usp.br / secretariacappesq2@hcnet.usp.br-sol

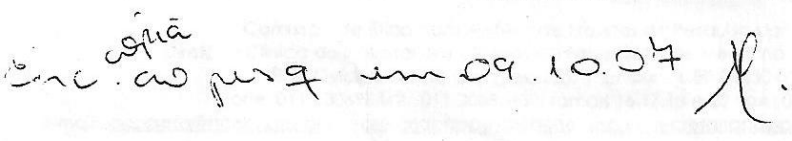




\section{re \\ Diretoria Clínica \\ Comissão de Ética para Análise de Projetos de Pesquisa - CAPPesa. \\ PARECER $-2^{\circ}$ relato}

\begin{tabular}{|l|l|}
\hline PROTOCOLO DE PESQUISA No: 0475/07 & $\begin{array}{l}\text { Data de entrada: } 11.09 .07 \\
\text { Data sessāo: } 03.10 .07\end{array}$ \\
\hline
\end{tabular}

TírULO DA PESQUISA: A relação entre ministros religiosos, médicos e pacientes no Instituto de Psquiatria do Hospital das clínicas de São Paulo

PESQUISADOR(A) RESPONSÁVEL: Prof. Dr. Francisco Lotufo Neto

PESQUISADOR (A) EXECUTANTE: LUiza Maria de Assunção

DEPARTAMENTO: Psiquiatria - DOUTORADO (orientador - Dr. Lisias Nogueira Negrão)

CONSIDERAÇŌES DO RELATOR APROVADAS PELO PLENÁRIO:

Os autores atenderam todos os esclarecimentos solicitados complementando o projeto com os dados.

CONCLUSÃO - APROVADO - lembrando que deveria ser incluido no projeto as duas entrevistas (anexadas - com a direção do Instituto de Psiquiatria e com o superintendente do HC). Quanto ao TCLE confeccionado para os três grupos, acrescentar espaço para o nome legivel do sujeito de pesquisa e lembrar que uma cópia fica com o pesquisador e outra com o participante. Também lembrar que somente 1 TCLE foi confeccionado em impresso do HC e os outros dois não. Verificar com a Instituição se os 3 deveriam ser confeccionados em impresso do $\mathrm{HC}$ ou os 3 serem de próprio punho.

\begin{tabular}{|l|l|l|}
\hline ENVIAR Á CONEP & $\begin{array}{l}\text { I SIM } \\
\text { INFORME A ÁREA TEMÁTICA: }\end{array}$ & X NĀO \\
\hline
\end{tabular}

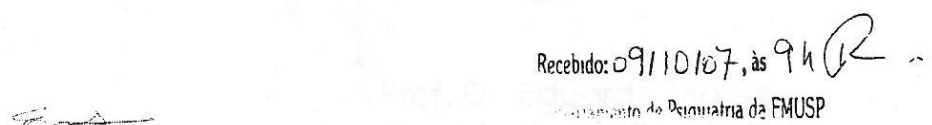

Prof.Dr. Eduardo Massad

Presidente da Comissão de

Ética para Análise de Projetos de Pesquisa

Enc. copic as perq en 09.10 .07

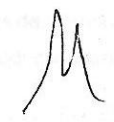

Comissâo de Ética para Análise de Projetos de Pesquisa do HCFMUSP e da FMUSP

Diretoria Clinica do Hospital das Clinicas da Faculdade de Medicina da Universidade de São Paulo

Rua Ovídio Pires de Campos. 225, $5^{\circ}$ andar - CEP 05430010 - São Paulo - SP

Fone: 011 - 30696442 011-30696431: ramais 16.17 .18 e 20 fax: 011 - 3069.6492 ramal 26 